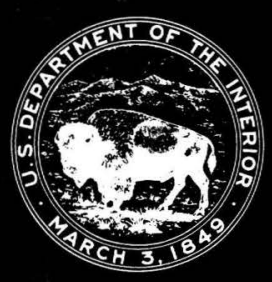

\title{
CHANNEL EROSION SURVEYS ALONG TAPS ROUTE, ALASKA, 1974
}

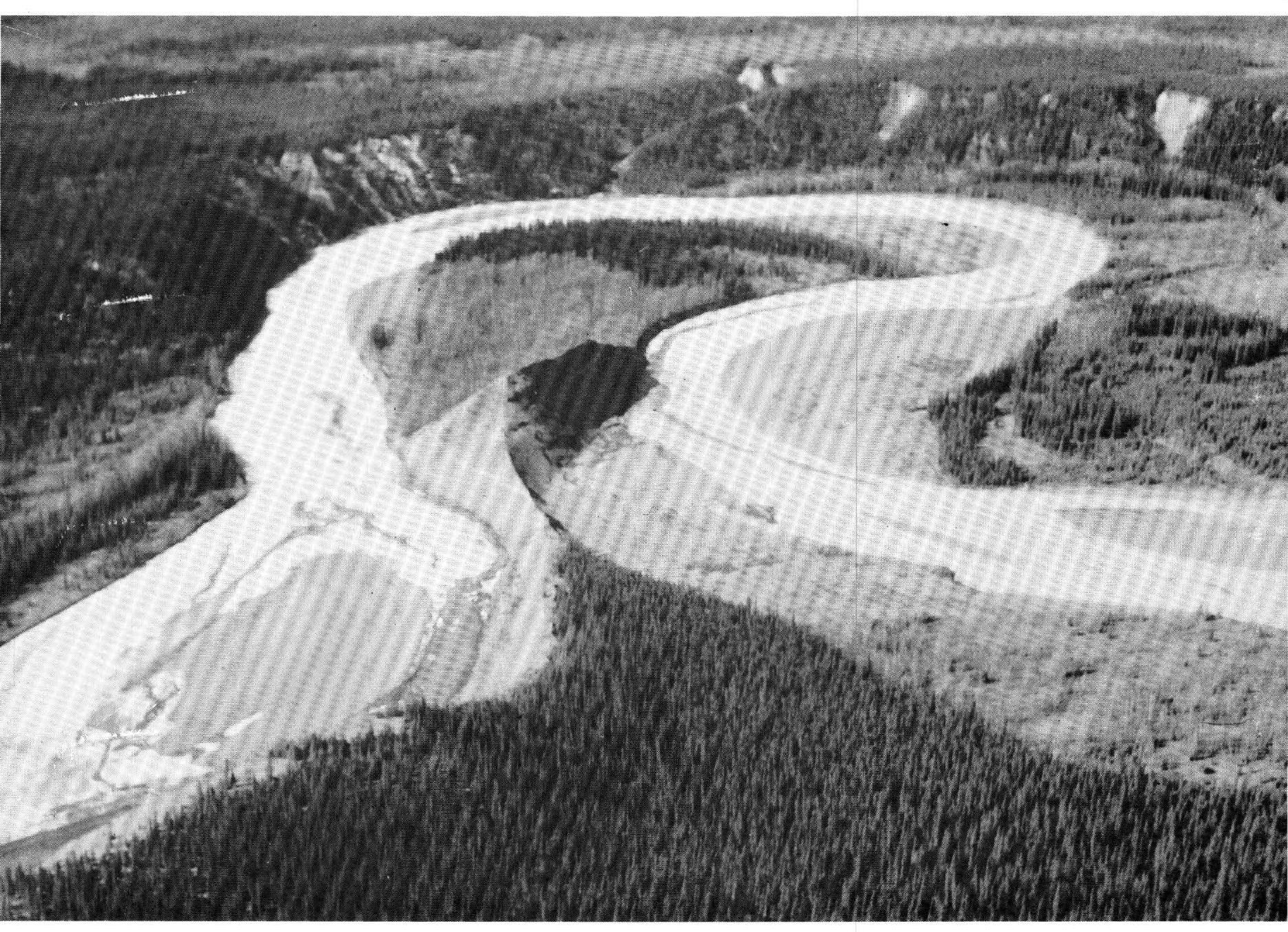

UNITED STATES DEPARTMENT OF THE INTERIOR GEOLOGICAL SURVEY 


\section{UNITED STATES \\ DEPARTMENT OF THE INTERIOR \\ GEOLOGICAL SURVEY}

CHANNEL EROSION SURVEYS ALONG TAPS ROUTE, ALASKA, 1974

By

Joseph M. Childers and Stanley H. Jones

OPEN-FILE REPORT

Anchorage, Alaska

1975 
Abstract......................... 1

Introduction. .................. 1

Preconstruction data. . . . . . . . . . . . . . 2

Surveillance program. ............... 5

Channel erosion surveys, 1974 . . . . . . . . . . . . . 5

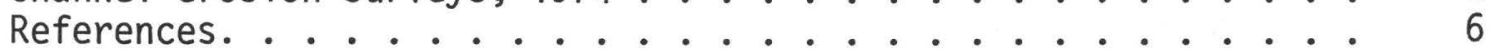

\section{ILLUSTRATIONS}

Figure 1. Channel erosion survey sites along the trans-Alaska pipeline............... 3

2. Aerial photograph of Sagavanirktok River near Sagwon,

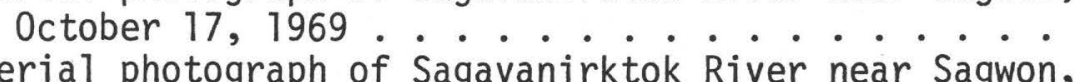

3. Aerial photograph of Sagavanirktok River near Sagwon, ross sections of Sagavanirktok River near Sagwon, July 30, 1971..............

5. Discharge hydrograph for Sagavanirktok River near

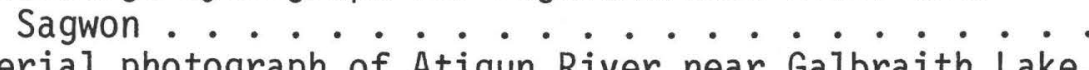

6. Aerial photograph of Atigun River near Galbraith Lake, October 17, 1969 . . . . . . . . .

7. Aerial photograph of Atigun River near Galbraith Lake, August 24, 1974..............

8. Cross sections of Atigun River near Galbraith Lake, July 31, 1971, and September 6,1974 ..... 16

9. Aerial photograph of Snowden Creek near Dietrich Camp, September 28, 1971 . . . . . . . . 19

10. Aerial photograph of Snowden Creek near Dietrich Camp, August 6, 1974 .......... . 20

11. Aerial photograph of Snowden Creek near Dietrich

12. Cross sections of Snowden Creek near Dietrich Camp,

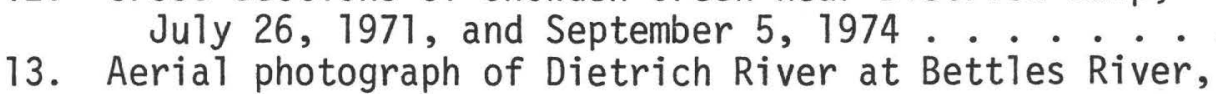

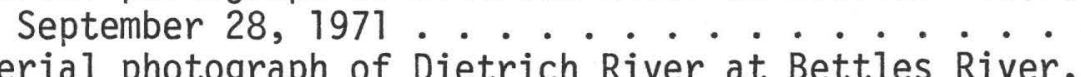

14. Aerial photograph of Dietrich River at Bettles River,

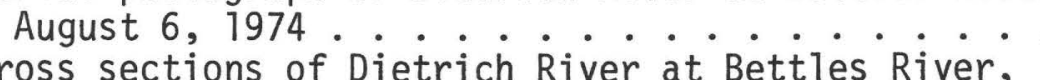

15. Cross sections of Dietrich River at Bettles River,

July 29,1971 , and September 5,1974 . Aerial photograph of Middle Fork Koyukuk River at
16.

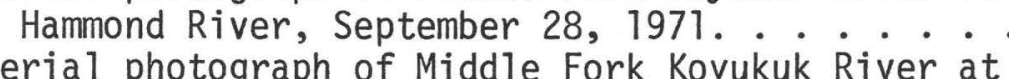

17. Aerial photograph of Middle Fork Koyukuk River at Hammond River, September 1, 1974 


\section{CONTENTS}

Page

Figure 18. Cross sections of Middle Fork Koyukuk River at Hammond River, July 27, 1971, and September 5,

19. Aerial photograph of Hammond River near Wiseman,

20. Aerial photograph of Hammond River near Wiseman,

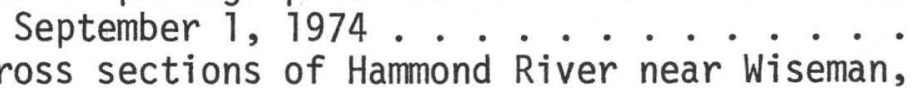

21. Cross sections of Hammond River near Wiseman, July 25, 1971, and September 5, 1974.

22. Aerial photograph of Middle Fork Koyukuk River near Wiseman, September 28, 1971 . . . . . . .

23. Aerial photograph of Middle Fork Koyukuk River near Wiseman, August 6, 1974 .

24. Cross sections of Middle Fork Koyukuk River near Wiseman, July 27, 1971, and September 4, 1974 . .

25. Discharge hydrograph for Middle Fork Koyukuk River near Wiseman.

26. Aerial photograph of South Fork Koyukuk River near Wiseman, September 28, $1971 \ldots 48$

27. Aerial photograph of South Fork Koyukuk River near

Wiseman, August 6,1974 . Cross sections of South Fork Koyukuk River near
28.

29. Aerial photograph of Jim River near Prospect Creek

30. Aerial photograph of Jim River near Prospect Creek

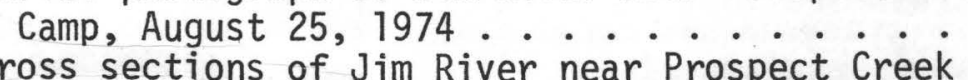

31. Cross sections of Jim River near Prospect Creek

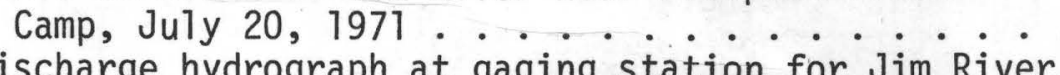

32. Discharge hydrograph at gaging station for Jim River

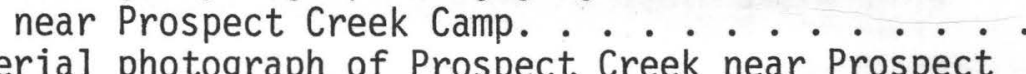

33. Aerial photograph of Prospect Creek near Prospect Creek Camp, September 28, 1971. . . - - .

34. Aerial photograph of Prospect Creek near Prospect Creek Camp, September 1, 1974

35. Aerial photograph of Prospect Creek near Prospect Creek Camp, September 1, 1974

36. Cross sections of Prospect Creek near Prospect

37. Aerial photograph of Kanuti River near Bettles,

September 28, 1971 Aerial photograph of Kanuti River near Bettles,
38. August 6, 1974.

39. Cross sections of Kanuti River near Bettles, Ju1y 22, $1971 \ldots \ldots 64$

40. Aerial photograph of Hess Creek near Livengood, September 28, 1971. 


\section{CONTENTS}

Page

Figure 41. Aerial photograph of Hess Creek near Livengood,

42. Cross sections of Hess Creek near Livengood, August 3,1971 ........... . . 68

43. Discharge hydrograph for Hess Creek near Livengood . 69

44. Aerial photograph of Chatanika River near 01nes, August 18, 1969.

45. Aerial photograph of Chatanika River near 01nes, September 4, 1974.

46. Cross sections of Chatanika River near oines,

August 3, 1971

47. Aerial photograph of Salcha River near Salchaket,

48. Aerial photograph of Saicha River near Saichaket,

August 31, 1974.

49. Cross sections of Salcha River near Salchaket, August 5, 1971, and September 16, 1974 ..... 77

50. Discharge hydrograph for Salcha River near Salchaket . 78

51. Aerial photograph of Flood Creek near Rapids, September 23, 1972 .

52. Aerial photograph of Flood Creek near Rapids, August 31, 1974.

53. Cross sections of Flood Creek near Rapids, September 1972

54. Aerial photograph of Gulkana River near Sourdough,

55. Aerial photograph of Guikana River near Sourdough, August 31, 1974.

56. Cross sections of Gulkana River near Sourdough, May 15, 1973, and May 23, $1974 \ldots . . .$.

57. Discharge and stage hydrograph for Gulkana River near Sourdough

58. Aerial photograph of Tazlina River near Glennallen, September 23, 1972

59. Aerial photograph of Tazlina River near Glennallen, August 31, 1974.

60. Cross sections of Tazlina River near Glennallen, August 22, 1973, and September 18, 1974. . . . . .

61. Discharge hydrograph for Tazlina River near Giennalien

62. Aerial photograph of Tazlina River near Glennallen, June 15, 1974.

63. Cross sections of Tazlina River near Glennalien at highway bridge, June 24, 1974, August 15, 1974, and August 24, 1974.

64. Aerial photograph of Klutina River near Copper Center, May 22, 1973 
Figure 65. Aerial photograph of Klutina River near Copper Center, August 31, 1974. .......... 100

66. Cross section of Klutina River near Copper Center, August 14, 1970.......... 101

67. Aerial photograph of Tonsina River near Tonsina, September 23,1972 ........... 103

68. Aerial photograph of Tonsina River near Tonsina, August 31,1974. . . . . . . . . . 104

69. Cross sections of Tonsina River near Tonsina, September 28, 1972 ........... 105

70. Discharge hydrograph for Tonsina River near Tonsina. . 107

71. Aerial photograph of Tiekel River at Tiekel, September 23,1972 ........... 109

72. Aerial photograph of Tiekel River at Tiekel, August 31,1974.............. 110

73. Cross sections of Tiekel River at Tiekel, May 13, 1973111

74. Aerial photograph of Tiekel River near Tiekel, September 23, 1972

75. Aerial photograph of Tiekel River near Tiekel, August 31, 1974.

76. Cross sections of Tiekel River near Tiekei, May 19,1973 ............ 115

77. Aerial photograph of Tsina River near Tiekei, September 23,1972 .......... 117

78. Aerial photograph of Tsina River near Tiekei, August $31,1974 . . . . . . .2118$

79. Cross sections of Tsina River near Tiekel, May 17, 1973 ............. 119

80. Aerial photograph of Tsina River near Ptarmigan, September 23,1972 . . . . . . . . . 122

81. Aerial photograph of Tsina River near Ptarmigan, August 31, 1974.

82. Cross sections of Tsina River near Ptarmigan, May 17, 1973 . . . . . . . . .

83. Aerial photograph of Tsina River at Ptarmigan, September 23, 1972

84. Aerial photograph of Tsina River at Ptarmigan, August 31,1974. . . . . . . . . . 128

85. Cross sections of Tsina River at Ptarmigan, July 1973. 129

86. Aerial photograph of Sheep Creek near Valdez, September 23, 1972 .

87. Aerial photograph of Sheep Creek near Valdez,

88. Cross sections of Sheep Creek near vaidez, May 19, 1973 .............. 138

89. Aerial photograph of Lowe River near Vaidez, September 23, 1972 . 


\section{CONTENTS}

Page

Figure 90. Aerial photograph of Lowe River near Valdez, August 31,1974. ........... 141

91. Cross sections of Lowe River near Valdez, November 10, 1970, and May 18, 1973...... . 142

92. Cross sections of Lowe River near Valdez at highway bridge, June 6, 1973, August 24, 1973, June 18, 1974, and August 29,1974......... 144

93. Discharge hydrograph for Lowe River near Valdez. . . . 145

TABLES

Table 1. Preconstruction and 1974 channel erosion results . . . .

FACTORS FOR CONVERTING ENGLISH UNITS TO INTERNATIONAL SYSTEM (SI) UNITS

Multiply English units

cubic feet per second $\left(\mathrm{ft}^{3} / \mathrm{s}\right)$

cubic yards $\left(y d^{3}\right)$

feet $(\mathrm{ft})$

miles (mi)
By

0.02832

0.764560

0.3048

1.609
To obtain SI units

cubic metres per second $\left(\mathrm{m}^{3} / \mathrm{s}\right)$

cubic metres $\left(\mathrm{m}^{3}\right)$

metres ( $m$ )

kilometres $(\mathrm{km})$ 

By Joseph M. Childers and Stanley H. Jones

\section{ABSTRACT}

Repeated site surveys and aerial photographs at 26 stream crossings along the trans-Alaska pipeline system (TAPS) route during the period 1969-74 provide chronologic records of channel changes that predate pipeline-related construction at the sites. The 1974 surveys and photographs show some of the channel changes wrought by construction of the haul road from the Yukon River to Prudhoe Bay and by construction of camps and working pads a 11 along the pipeline route. No pipeline crossings were constructed before 1975. These records of channel changes together with flood and icing measurements are part of the United States Department of the Interior's continuing surveillance program to document the hydrologic aspects of the trans-Alaska pipeline and its environmental impacts.

\section{INTRODUCTION}

The U.S. Geological Survey has a threefold responsibility with respect to water resources along the route of the trans-Alaska pipeline system: to investigate possible hydrologic hazards to the pipeline; to investigate possible impacts of the pipeline on water resources; and to develop a better understanding of arctic hydrology.

Because the pipeline route crosses and lies within many stream channels, one of the obvious hydrologic hazards is channel erosion. It was considered a major hazard by R. F. Hadley and G. C. Lusby (written commun., 1969) after a short reconnaissance of the proposed route, and also by the U.S. Water Resources Council in a national assessment of water resources (1968). The Department of the Interior has also recognized the channel erosion problems in considering the environmental impacts of TAPS and has stipulated conditions for their control (U.S. Department of the Interior, 1972a, b, c). The Alyeska Pipeline Service Company, which is to build and operate TAPS, has described methods for complying with the Department of the Interior's stipulations for channel and erosion control (Alyeska Pipeline Service Co., written commun., project description, 3 volumes of text and 20 appendix volumes, 1971).

Two basic channel erosion problems are: (1) erosion that could be severe enough to cause pipeline rupture and oil spillage, and (2) erosion that could cause water-quality changes through increased concentration of suspended sediment. Erosion that could endanger the 
pipeline probably would result from major floods, from the cumulative lateral movement of channels over a period of years (Brice, 1971), from vertical scour in large alluvial flood plains (the total flood channel), and perhaps also from flow around or under ice or frozen streambeds. Erosion that would alter water quality through increased concentration of suspended sediment may be most likely in small streams whose watersheds contain fine-grained erodable soils.

This report describes channel erosion along the TAPS route by means of illustrations showing comparative channel changes during the period 1969-74 for 26 stream channel sites (fig. 1). The information presented will be useful in studies of channel erosion including streambed scour, bank erosion, and rechannelization. This report also describes a surveillance program for detecting and measuring significant erosion and the important factors causing erosion, such as flood discharge, icing development, and construction activities. The principal erosion information presented herein is lateral streambed change documented by comparison of aerial photographs of route segments known to have undergone significant change due to road, airstrip or camp construction, and floods. Cross sections of sites at which changes were noted were surveyed and those changes are reported. At some cross-section sites flood or high-water measurements were obtained to document streambed scour.

Two earlier reports (Childers, 1972 and 1975) provide descriptions of preconstruction conditions and present the results of channel erosion surveys at selected sites along the TAPS route. A companion report (Childers, 1974) presents the results of flood surveys of bankfull discharge and maximum evident flood discharge at most of those sites.

\section{PRECONSTRUCTION DATA}

Parts of streambeds may be scoured or filled rapidly during a flood. The maximum scour during a flood can be measured reliably by continuous monitoring. In general, this is impractical in studies such as these along the pipeline route which are intended mainly to measure the net erosion that occurs between surveys; only net streambed scour or fill, bank erosion, and rechannelization have been measured.

A11 the sites selected are located in large alluvial valleys. Most sites are on meandering and braided streams; three sites are on streams on alluvial fans. Some of the streams flow in the permafrost region and some are subject to outburst floods from glacier-dammed lakes. Thus, the sites selected represent regions with differing hydrologic conditions.

At all sites vertical aerial photography was obtained during the preconstruction period $1969-73$ at scales ranging from $1: 2,400$ to $1: 24,000$. These photographs document the preconstruction topography at each site and provide an easy-to-use reference from which to measure 


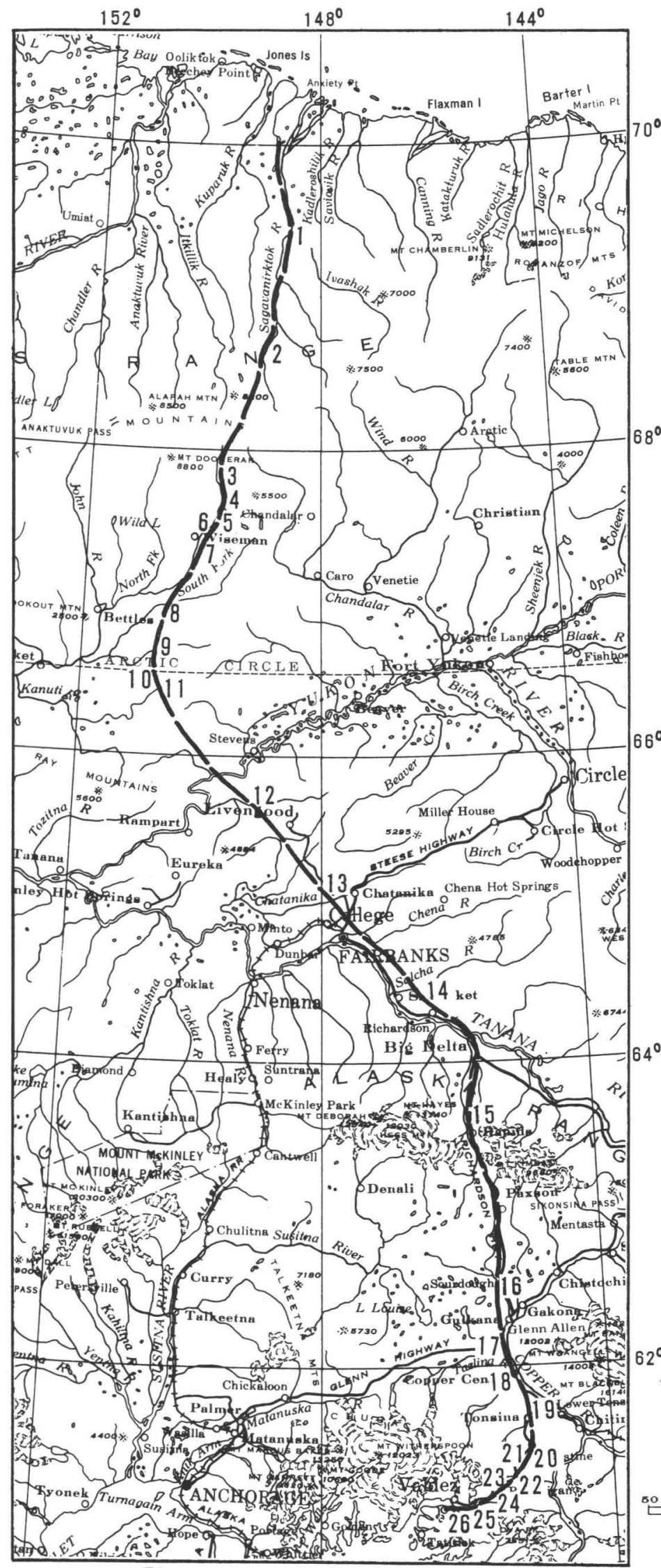

\section{EXPLANATION}

Trans-Alaska pipeline

1. Sagavanirktok River

2. Atigun River

3. Snowden Creek

4. Dietrich River

5. Middle Fork Koyukuk River

6. Hammond River

7. Middle Fork Koyukuk River

8. South Fork Koyukuk River

9. Jim River

10. Prospect Creek

11. Kanuti River

12. Hess Creek

13. Chatanika River

14. Salcha River

15. Flood Creek

16. Gulkana River

17. Tazlina River

18. Klutina River

19. Tonsina River

20. Tiekel River

21. Tiekel River

22. Tsina River

23. Tsina River

24. Tsina River

25. Sheep Creek

26. Lowe River

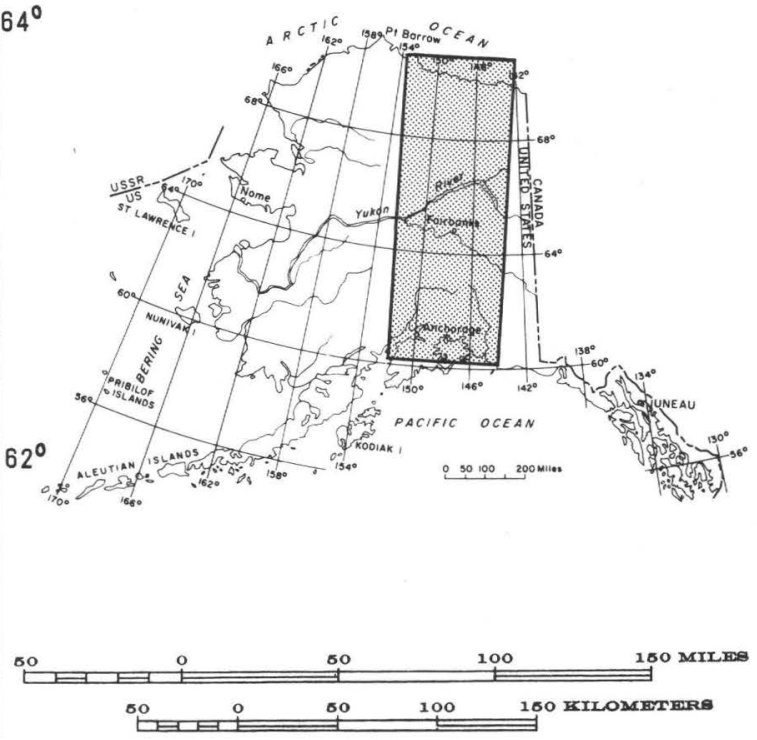

Figure 1.-- Channel erosion survey sites along the Trans-Alaska pipeline. 
further erosion. The resolution permits detection of as little as $10 \mathrm{ft}(3 \mathrm{~m})$ of bank erosion. The locations of the channel cross sections, TAPS centerline section (TAPS $C / L$ ), and photograph control points (PC) are indicated on the aerial photographs.

To determine the net erosion that occurs between surveys, cross sections or ground profiles were surveyed across the channel at the pipeline crossing site and upstream and downstream from the crossing but outside the probable construction zone. The upstream and downstream cross sections are marked by permanent photograph control points so they can be recovered for future surveys. Transit-stadia surveys were made to establish the vertical and horizontal location of the cross-section photograph control points.

Descriptions of the streambeds and flood plains (Childers, 1972 and 1975) document conditions that affect resistance to channel erosion. The descriptions include information on streambed material size and apparent stability; on bank material, bank slopes and their apparent stability; on vegetation; and on the presence of permafrost. The bankfull channel dimensions, the location and elevation of existing highwater marks, and ice or debris scars on trees also are noted. Flood surveys of bankfull discharge and maximum evident flood discharge (Childers, 1974) are documented at most of the sites.

During the time of data collection for this study, the Alyeska Pipeline Service Company began to gather data for detailed design of the pipeline at stream crossings. The Alyeska Pipeline Service Company data include preconstruction information similar to that described above and can also be used in measuring subsequent channel erosion at many additional sites.

Selected data from preconstruction surveys are presented in a summary (table 1) of site name and location, bankfull main-channel data, bed material description, and flood information.

The basic data, including field-survey notes, selected aerial photographs, ground photographs, and tabulated indexes of aerial photography along the trans-Alaska pipeline route are in files of the U.S. Geological Survey, Alaska District, Water Resources Division in Anchorage, Alaska.

Other reports of channel studies along the TAPS route by the Geological Survey are available from the Alaska District office. Measurements of lateral erosion at proposed river crossing sites of the Alaska pipeline comparing 1969 aerial photography with that of about 1950 were reported by Brice (1971). Hydraulic geometry of some Alaskan streams south of the Yukon River was surveyed and described by Emmett (1972). Channel conditions of the Yukon River at the TAPS crossing were discussed in a report by Childers and Lamke (1973). 


\section{SURVEILLANCE PROGRAM}

A channel erosion surveillance program has been developed to feature use of low-altitude stereophotography and aerial strip photography. Annual summer low-altitude stereophotographs along the route show the location and extent of channel erosion. By comparison with preconstruction data, significant erosion can be detected. Annual ground surveys of the cross sections will document lateral erosion and vertical streambed scour. Construction activities and flood and icing conditions will be described annually.

At some sites a flood-discharge measurement is planned to determine maximum vertical streambed scour at the cross sections. This work requires a flood-warning system, specialized equipment, trained personnel, and arduous and sometimes hazardous work. The streambed scour probability for buried pipelines during floods is one of the major design considerations and one for which little reliable flood information is available. Therefore, efforts to monitor flood discharges are an important element of this surveillance.

\section{CHANNEL EROSION SURVEYS, 1974}

During 1974 the haul road covering the 400 miles $(644 \mathrm{~km})$ from the Yukon River to Prudhoe Bay was constructed. Much of the road is in stream flood plains, and the gravel for road construction was mostly obtained from flood plains. Gravel pads for camps and pump stations were also constructed on flood plains. For all this construction, 20 million cubic yards ( 15 million cubic metres) of gravel were excavated from 109 gravel pits. The haul road and other access roads required construction of 20 bridges and about 1,350 culverts (Millard Kahler, State of Alaska, Dept. of Highways, oral commun., 1974). Some of the bridges and culverts are floodflow constrictions. This flood-plain construction was the most significant change in the floodways during 1974.

The only significant flood along the TAPS route in 1974 was on the Tazlina River. That flood resulted from the outburst of a glacier-dammed 1ake. The flood overflowed a forested flood plain on a meander between the pipeline crossing site and the Richardson Highway bridge. The overflow began to erode a cutoff channel through the flood plain. Incipient overflow occurred on the flood plain supporting the TAPS Tazlina camp.

Channel icings, although exceptionally large at some locations along the TAPS route, caused no significant channel erosion in 1974.

Channel erosion data collected in 1974 (table 1) include aerial photograph date and scale, measured maximum lateral bank erosion, and maximum vertical change of the thalweg. Low-altitude aerial stereophotography of 13 northern channel erosion sites was obtained for the Geological Survey during August 1974 at a scale of 1:6,000. Alyeska Pipeline Service Company acquired low-altitude aerial strip photography 
of the entire pipeline right-of-way and winter trails during August and September 1974 at a scale of 1:6,000. Other photographs included in this report are high-altitude aerial stereophotography taken for the Alaska Pipeline office of the entire pipeline right-of-way for the period June through August 1974 at a scale of 1:76,000. By comparing these aerial photographs with preconstruction aerial photographs, changes such as lateral bank erosion and construction disturbances such as material removal, road fill encroachment in the flood plain, and bridge construction are documented. For each site the distance of lateral channel migration was measured by superimposing the preconstruction aerial photograph on the 1974 aerial photograph of the same area through the use of a Zeiss zoom transfer scope.

\section{REFERENCES}

Brice, J. C., 1971, Measurement of lateral erosion at proposed river crossing sites of the Alaska pipeline: U.S. Geol. Survey open-file report, $39 \mathrm{p}$.

Childers, J. M., 1972, Channel erosion surveys along proposed TAPS route, Alaska, July 1971: U.S. Geol. Survey open-file report, 79 p. 1974, Flood surveys along TAPS route, Alaska: U.S. Geol. Survey open-file report, $16 \mathrm{p}$.

1975, Channel erosion surveys along southern segment of the TAPS route, Alaska, 1972 and 1973: U.S. Geol. Survey open-file report, $57 \mathrm{p}$.

Childers, J. M., and Lamke, R. D., 1973, Flood survey at proposed TAPS crossing of Yukon River near Stevens Village, Alaska: U.S. Geol. Survey open-file report, $12 \mathrm{p}$.

Emmett, W. W., 1972, The hydraulic geometry of some Alaskan streams south of the Yukon River: U.S. Geol. Survey open-file report, $102 \mathrm{p}$.

U.S. Department of the Interior, 1972a, Summary, introduction, and project description, v. 1 of Final Impact Statement, Proposed Trans-Alaska Pipeline: National Technical Information Service (distributor) PB-206 921-1, U.S. Dept. of Commerce, 322 p., 1 appendix.

1972b, Environmental setting of the pipeline system, v. 2 of Final Environmental Impact Statement, Proposed Trans-Alaska Pipeline: National Technical Information Service (distributor), PG-206 921-2, U.S. Dept. of Commerce, 449 p., 1 appendix. 1972c, Evaluation of environmental impact, v. 4 of Final Environmental Impact Statement, Proposed Trans-Alaska Pipeline: National Technical Information Service (distributor) PB-206 921-4, U.S. Dept. of Commerce, $637 \mathrm{p}$.

U.S. Water Resources Council, 1968, The Nation's water resources; Pt. 1, The Nation's water and related land resources: Washington, U.S. Water Resources Counci1, p. 1-29, fig. 1-20. 
Table 1.--Preconstruction and 1974 channel erosion results

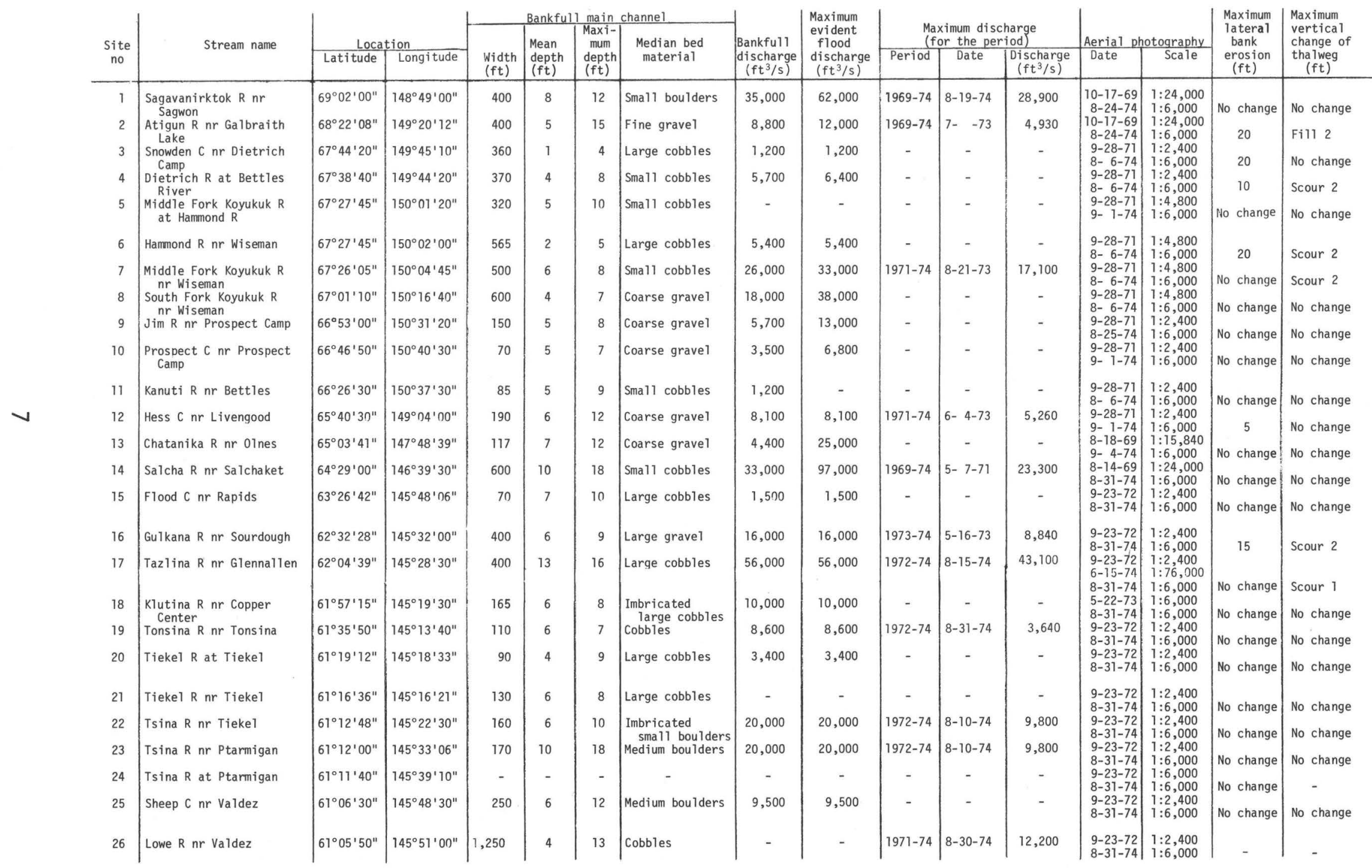


Location.--lat $69^{\circ} 02^{\prime} 00^{\prime \prime}$, long $148^{\circ} 49^{\prime} 00^{\prime \prime}$, in NW/ $\frac{1}{4}$ sec.9, T.5 S., R.14 E., $4.5 \mathrm{mi}(7.2 \mathrm{~km})$ upstream from Lupine River and about $26 \mathrm{mi}$ (42 km) south of Sagwon.

[Sagavanirktok (A-4) 1:63,360, U.S. Geological Survey map.]

Channel conditions.--High-altitude vertical aerial stereophotography (scale 1:24,000) was obtained October 17, 1969, (fig. 2) to document preconstruction topography of the site. Vertical aerial stereophotography (scale 1:6,000) taken August 24, 1974, (fig. 3) shows no significant channel erosion or construction activities have occurred in the proposed crossing reach since October 17, 1969. Three cross sections (fig. 4) were surveyed July 30,1971 , to define preconstruction ground profiles in the crossing reach. On September 6, 1974, a channel survey of the three cross sections found no significant lateral erosion.

Floods.--No significant overbank floods occurred during the period of the erosion investigation 0ctober 17, 1969, through September 6, 1974. The maximum observed discharge for the period, 28,900 $\mathrm{ft}^{3} / \mathrm{s}\left(818 \mathrm{~m}^{3} / \mathrm{s}\right.$ ) (fig. 5 ), was confined to the main channel far below the maximum evident flood and bankfull stage. 


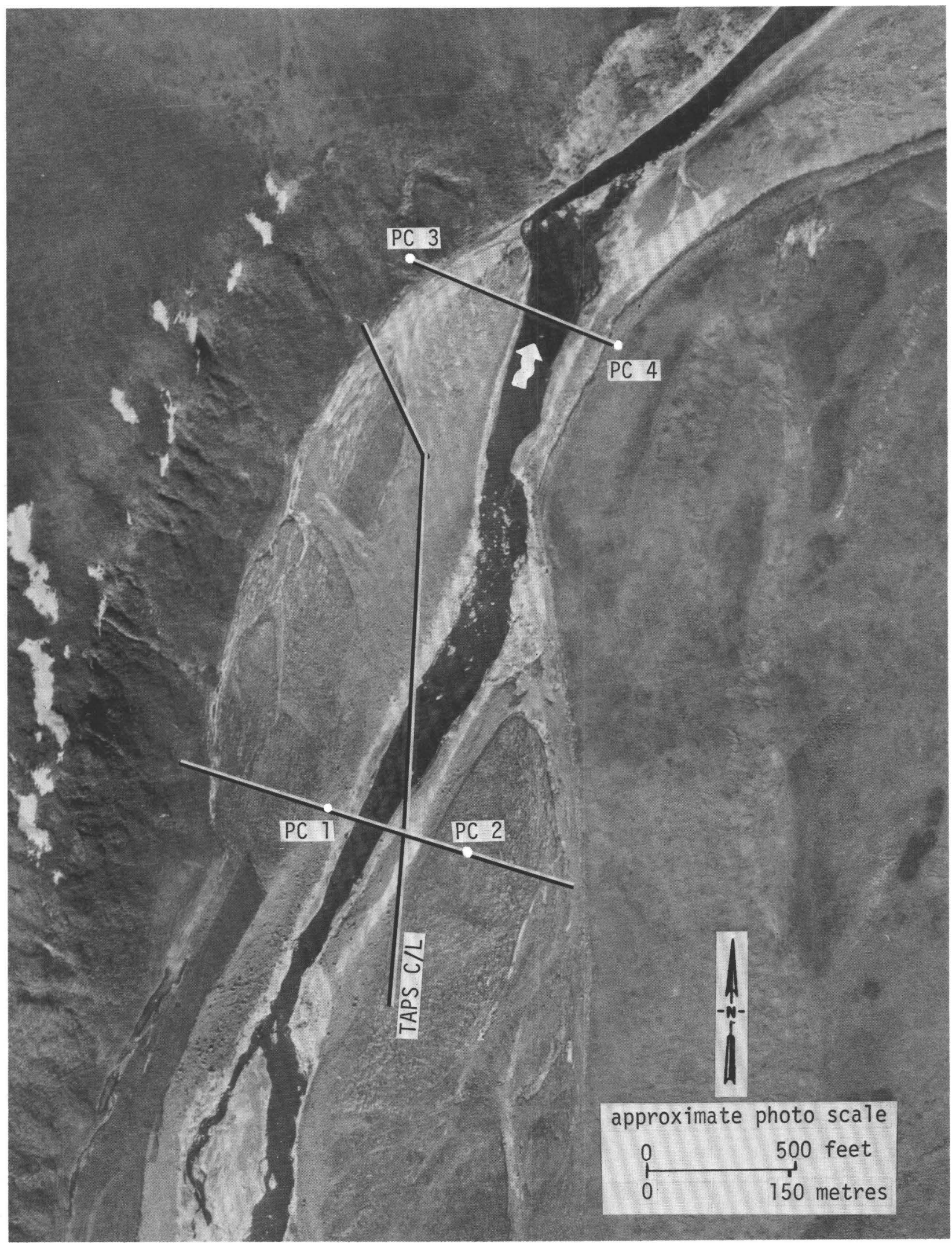

Figure 2. -- Sagavanirktok River near Sagwon, October 17, 1969. TOBIN RESEARCH INC. 


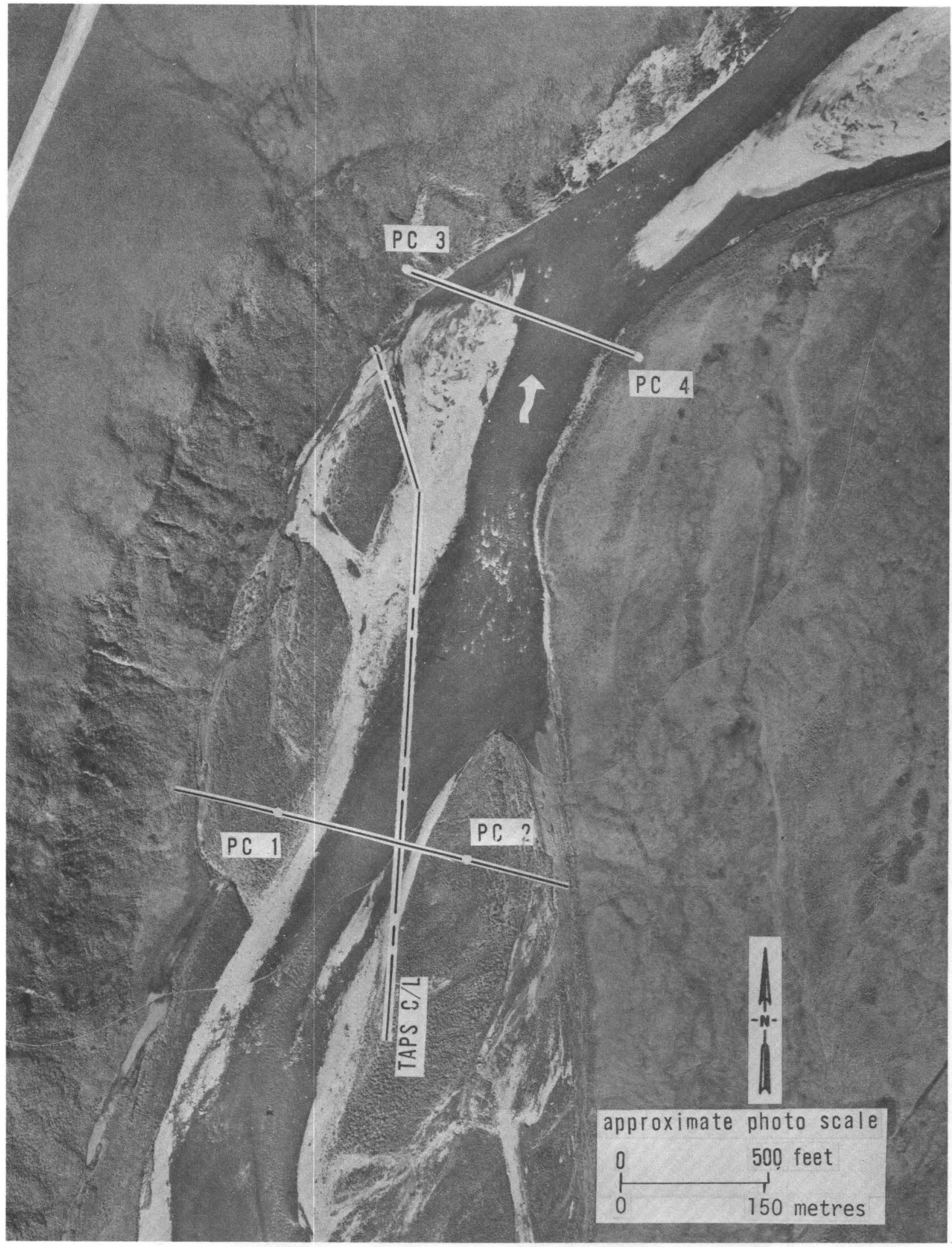

Figure 3. -- Sagavanirktok River near Sagwon, August 24, 1974. AlR PHOTO TECH. 

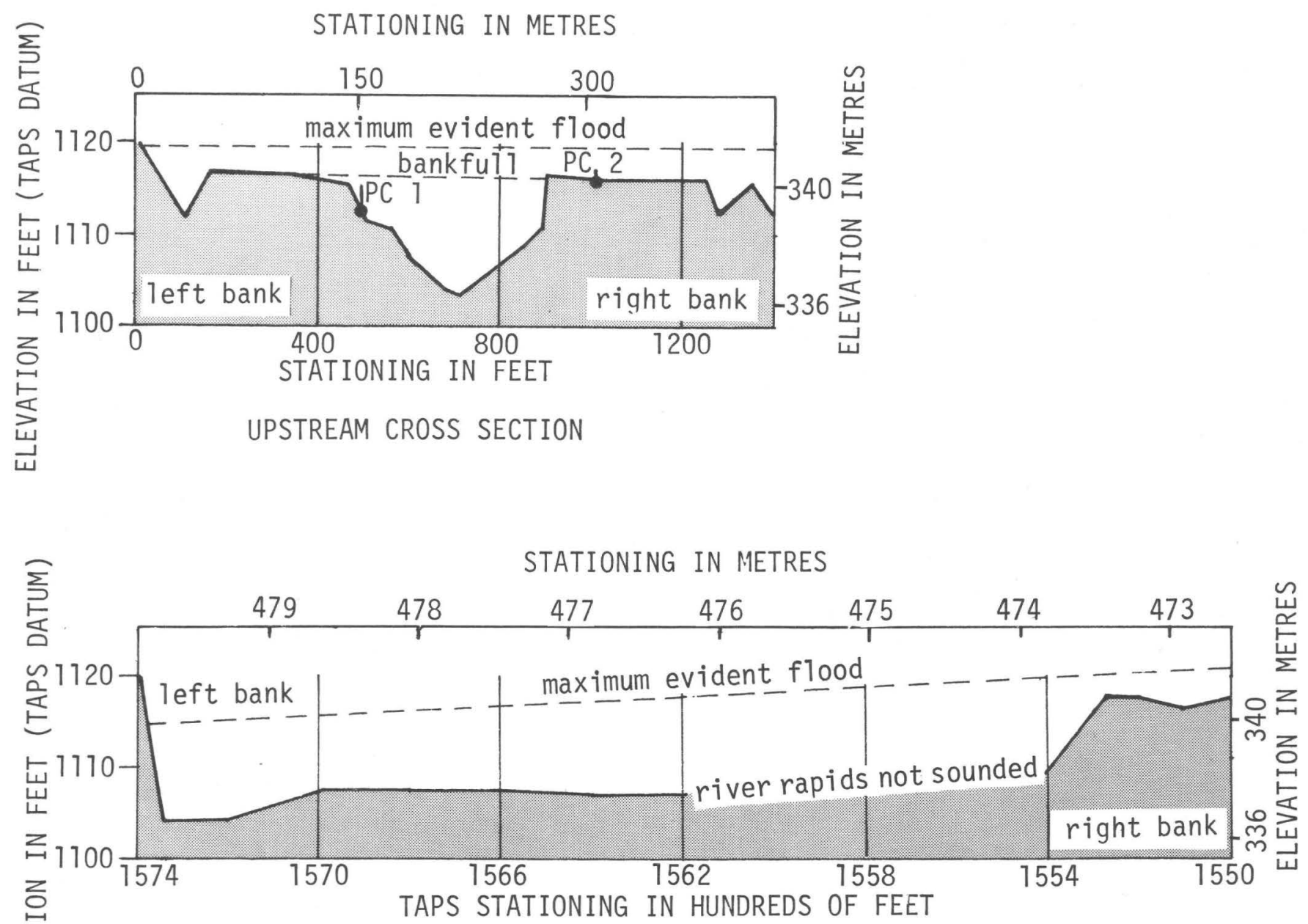

TAPS CENTERLINE CROSS SECTION

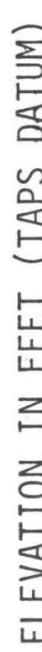

STATIONING IN METRES

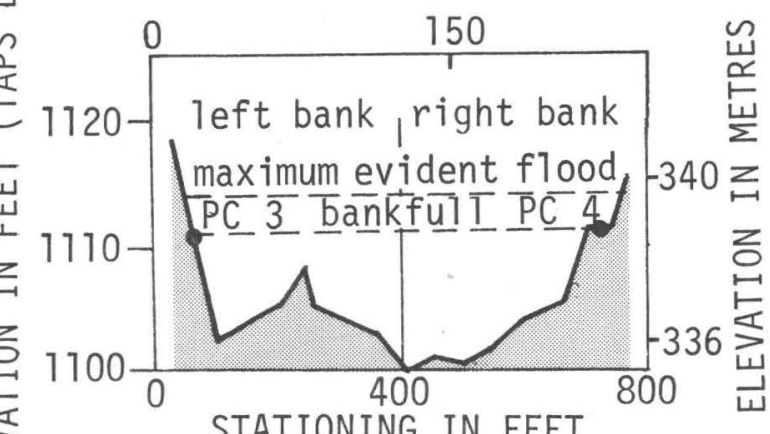

DOWNSTREAM CROSS SECTION

Figure 4.-- Cross sections of Sagavanirktok River near Sagwon, July 30, 1971. 


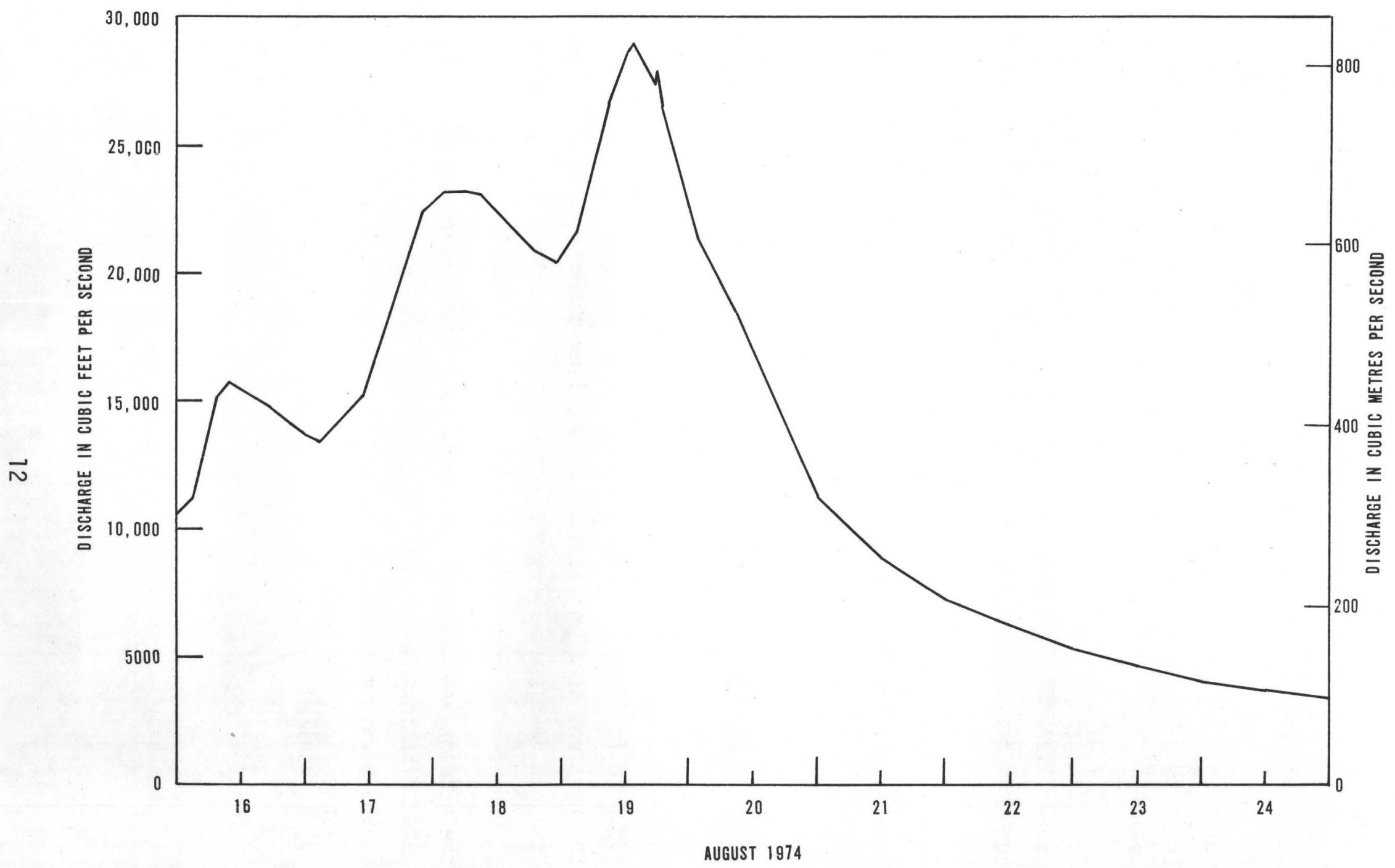

Figure 5.-- Discharge hydrograph for Sagavanirktok River near Sagwon. 
Location.--Lat $68^{\circ} 22^{\prime} 08^{\prime \prime}$, long $149^{\circ} 20^{\prime} 12^{\prime \prime}$, in SW/ $\frac{1}{4}$ sec.28, T.12 S.,

R.12 E., $6 \mathrm{mi}(10 \mathrm{~km})$ upstream from the mouth of Galbraith Lake outlet.

[Phillip Smith Mountains (B-4) 1:63,360, U.S. Geological Survey map.]

Channel conditions.--High-altitude vertical aerial stereophotography (scale 1:24,000) was obtained 0ctober 17, 1969, (fig. 6) to document preconstruction topography at the site. Vertical aerial stereophotography (scale 1:6,000) taken August 24, 1974, (fig. 7) shows lateral bank erosion of $20 \mathrm{ft}(6 \mathrm{~m})$ along the right bank of the upstream section and a small overflow channel has developed along the left bank of the downstream section. No significant erosion has occurred in the TAPS centerline section. There was no construction activity in the crossing reach since 0ctober 17 , 1969. Three cross sections (fig. 8) were surveyed July 31, 1971, to define preconstruction ground profiles in the crossing reach. On September 6, 1974, a channel survey of the three cross sections found $20 \mathrm{ft}(6 \mathrm{~m})$ of lateral bank erosion along the right bank of the upstream section and a small overflow channel about $4 \mathrm{ft}(1 \mathrm{~m})$ deep has developed along the left bank of the downstream section.

Floods.--No significant overbank floods occurred during the period of the erosion investigation 0ctober 17, 1969, through September 6, 1974. The maximum observed discharge for the period, 4,930 $\mathrm{ft}^{3} / \mathrm{s}$ $\left(1,503 \mathrm{~m}^{3} / \mathrm{s}\right)$, was confined to the main channel below the maximum evident flood and bankfull stage. 


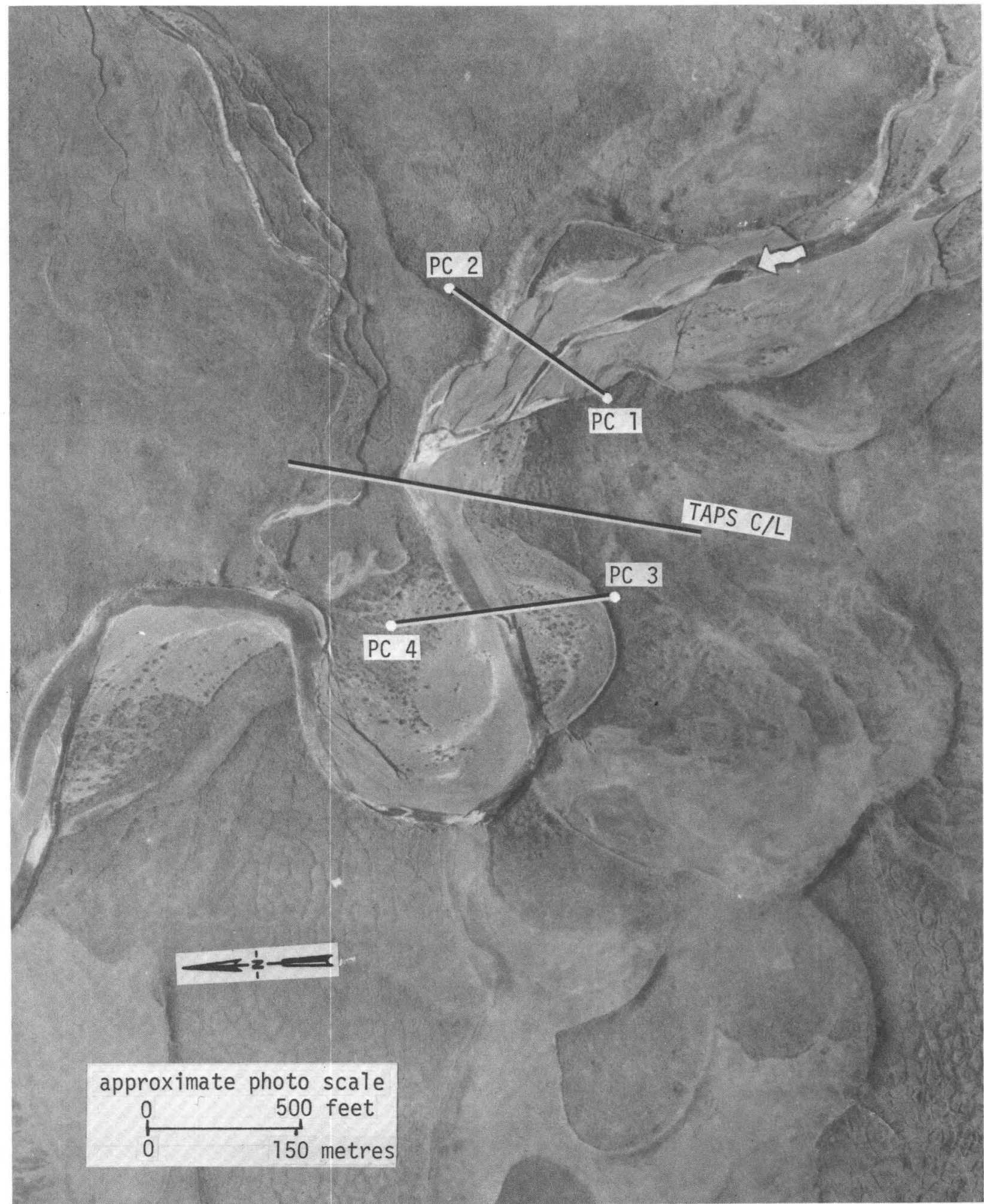

Figure 6. -- Atigun River near Galbraith Lake, October 17, 1969. TOBIN RESEARCH INC. 


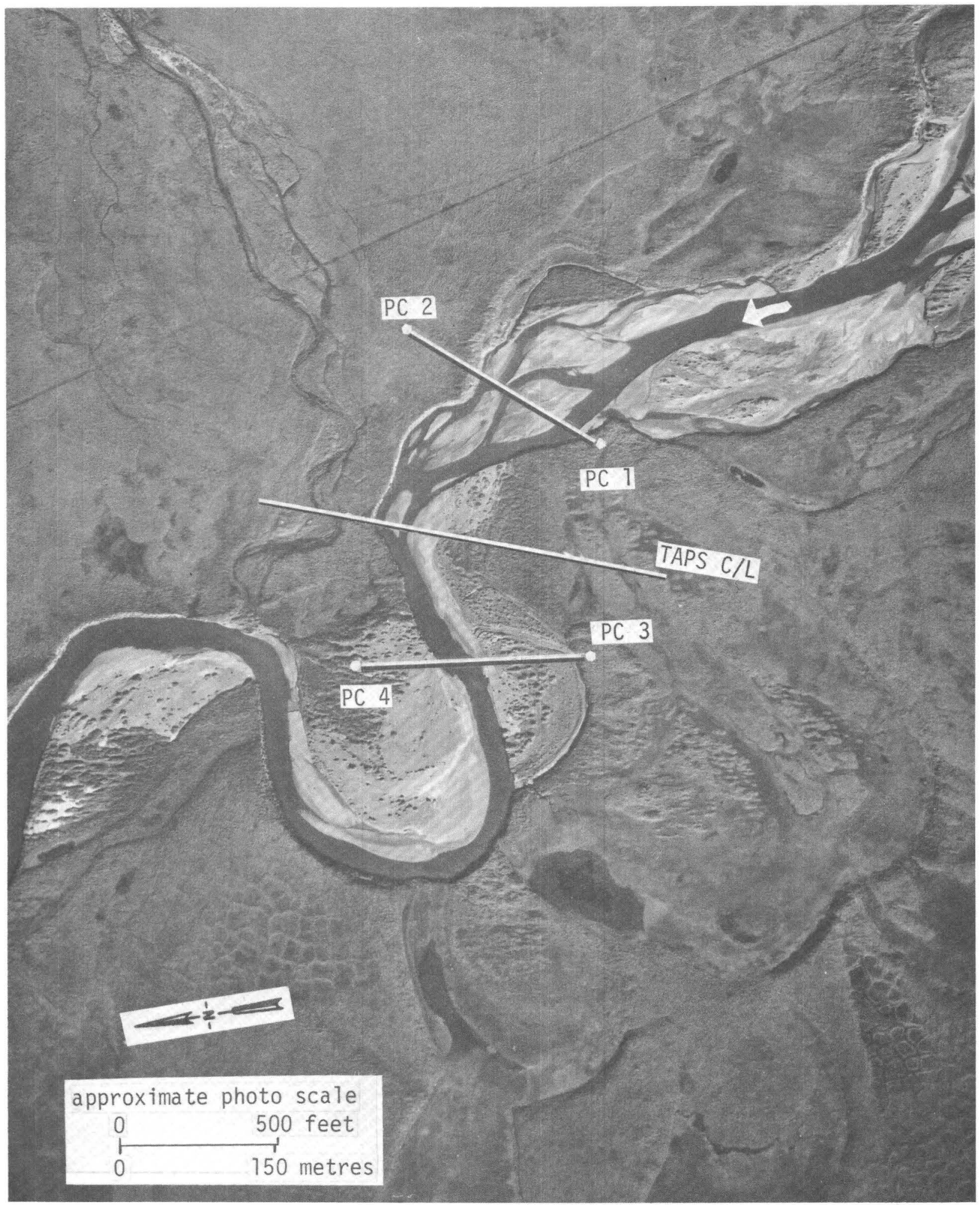

Figure 7. -- Atigun River near Galbraith Lake, August 24, 1974. AIR PHOTO TECH. 


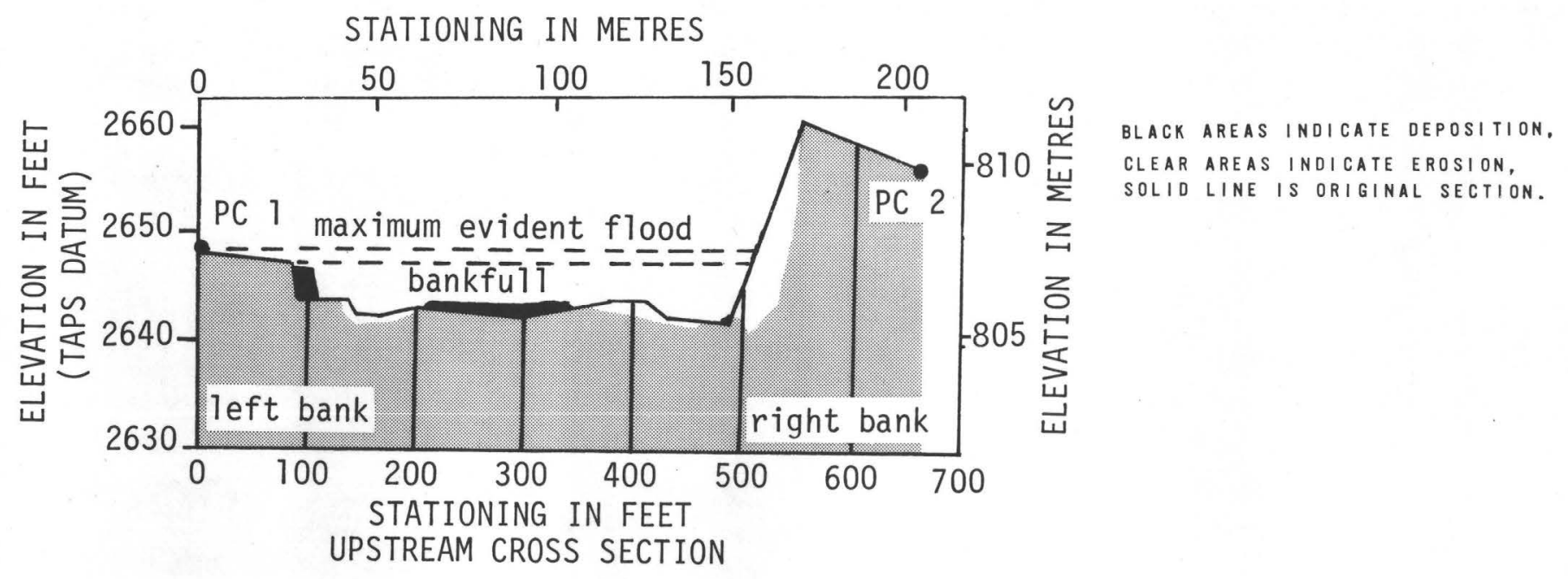

के

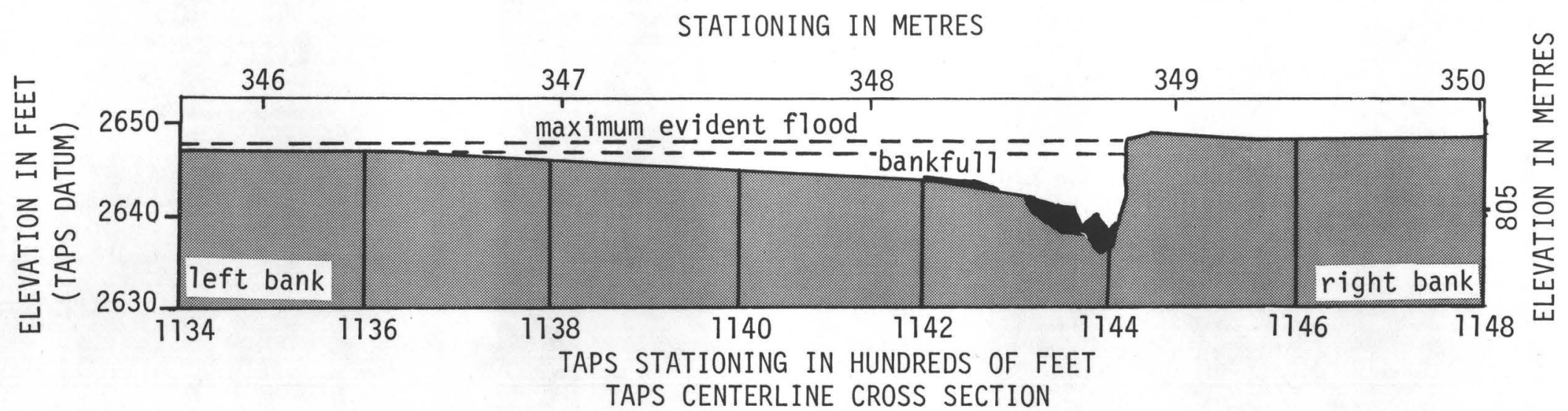

Figure 8.-- Cross sections of Atigun River near Galbraith Lake, July 31, 1971 and September 6, 1974. 


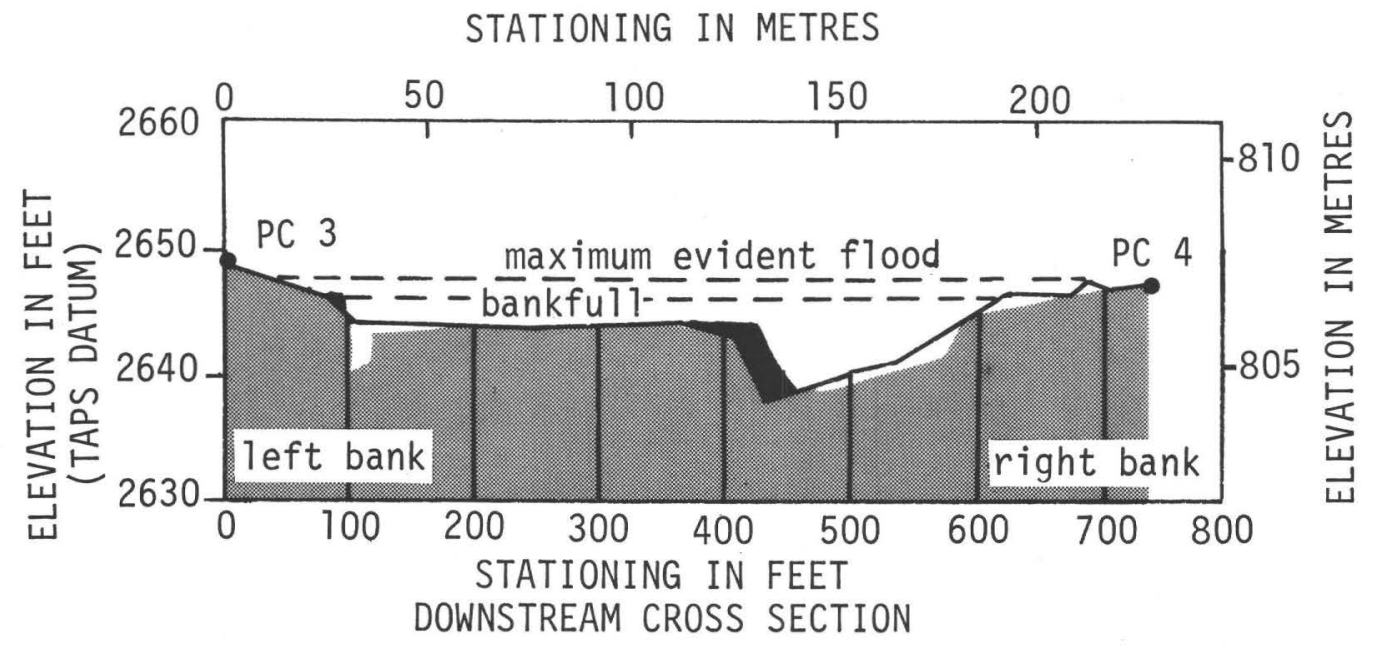

BLACK AREAS INDICATE DEPOSITION,

CLEAR AREAS INDICATE EROSION,

SOLID LINE IS ORIGINAL SECTION.

Figure 8. -- Cross sections of Atiqun River near Galbraith Lake, Ju1y 31, 1971 and September 6, 1974 -- Continued. 
Location.--Lat $67^{\circ} 44^{\prime} 20^{\prime \prime}$, long $149^{\circ} 45^{\prime} 10^{\prime \prime}$, in SW/ $\frac{1}{4}$ sec. 26, T. 34 N., R.10 W., $0.5 \mathrm{mi}(0.8 \mathrm{~km})$ upstream from mouth of Dietrich River, and about $25 \mathrm{mi}(40 \mathrm{~km})$ northeast of Wiseman.

[Chandalar (C-6) 1:63,360, U.S. Geological Survey map.]

Channel conditions.--Low-altitude vertical aerial stereophotography (scale 1:2,400) was obtained September 28, 1971, (fig. 9) to document preconstruction topography at the site. Vertical aerial stereophotography (scale 1:6,000) taken August 6, 1974, (figs. 10 and 11) shows significant change throughout the crossing reach. A large material-removal site is located in the stream channel and on the left bank of the flood fan at the pipeline crossing. A culvert and road fill have been installed across the Snowden Creek flood fan $800 \mathrm{ft}(240 \mathrm{~m})$ above the pipeline crossing. Three cross sections (fig. 12) were surveyed Ju1y 26, 1971, to define preconstruction ground profiles in the crossing reach. On September 5, 1974, a channel survey of the upstream and downstream sections (fig. 12) showed significant change. The upstream section shows about $20 \mathrm{ft}(6 \mathrm{~m})$ of lateral erosion along the left bank of the main channel. The downstream section shows about $20 \mathrm{ft}(6 \mathrm{~m})$ of lateral erosion along the right bank and a large quantity of floodfan material removed from the left bank flood plain.

Floods.--No significant overbank floods occurred during the period of the erosion investigation July 26, 1971, through September 5, 1974. 


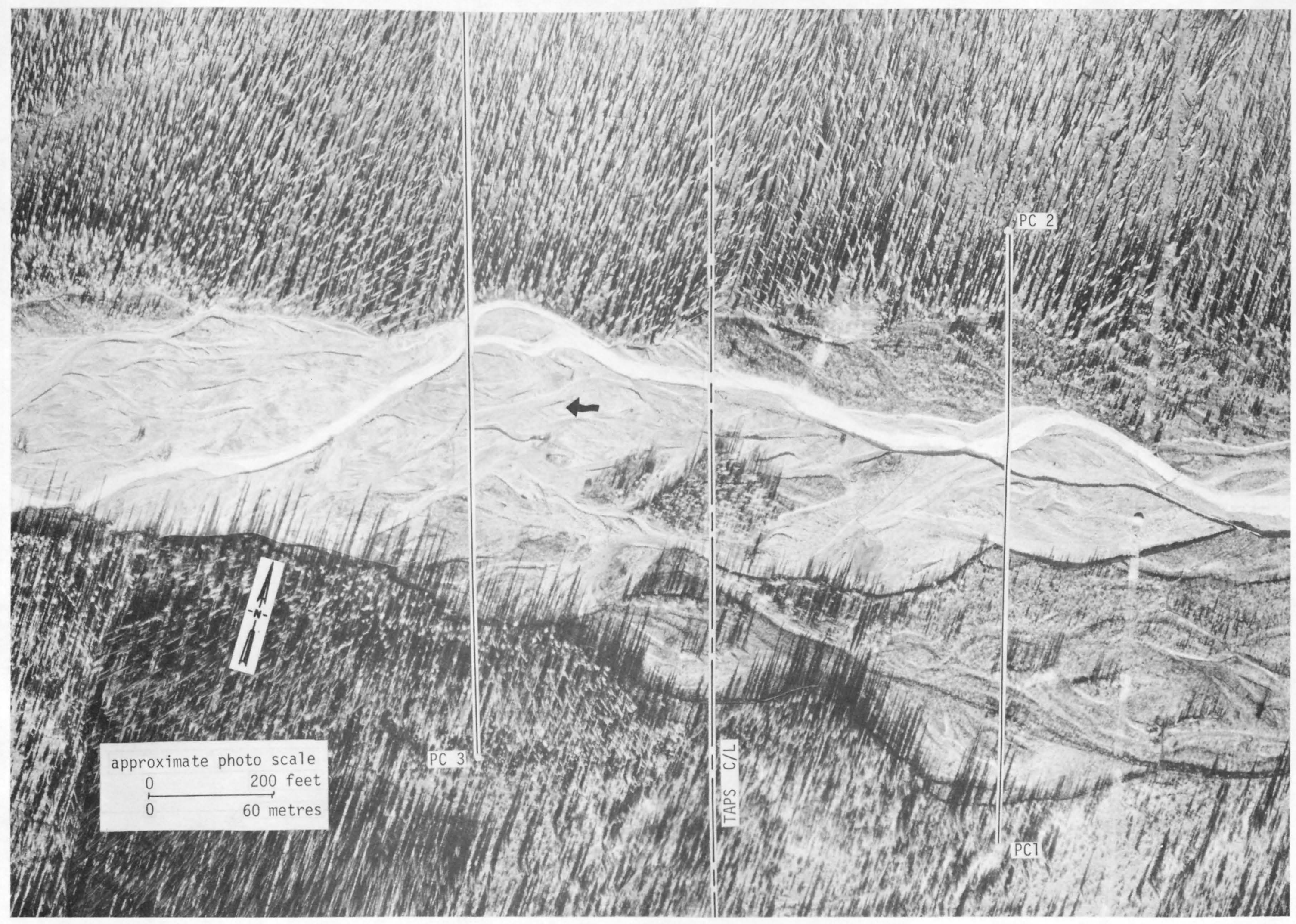

Figure 9. -- Snowden Creek near Dietrich Camp, September 28, 1971. WALKER-ALASKA INC. 


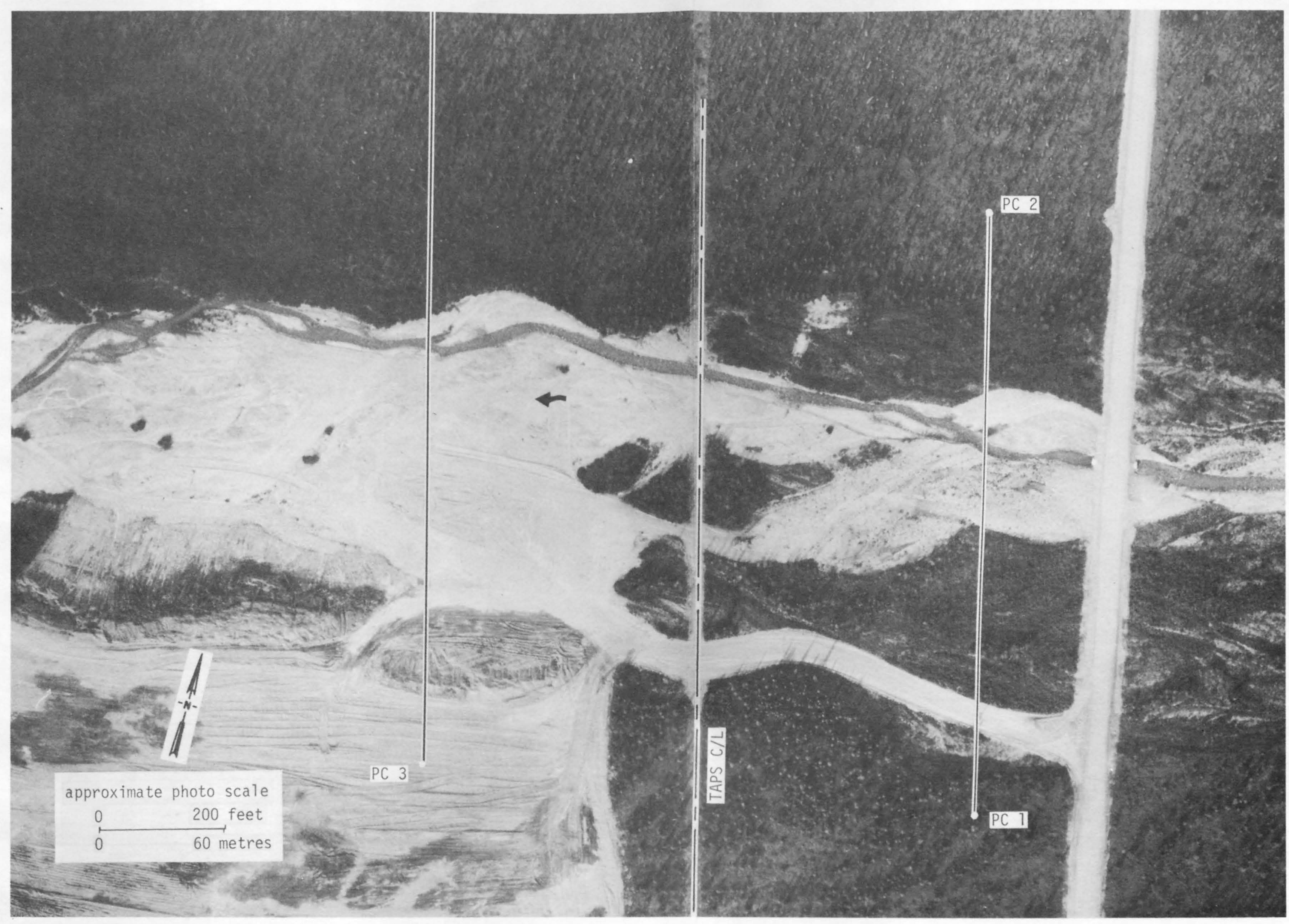

Figure 10. -- Snowden Creek near Dietrich Camp, August 6, 1974. AIR Рното тесн. 


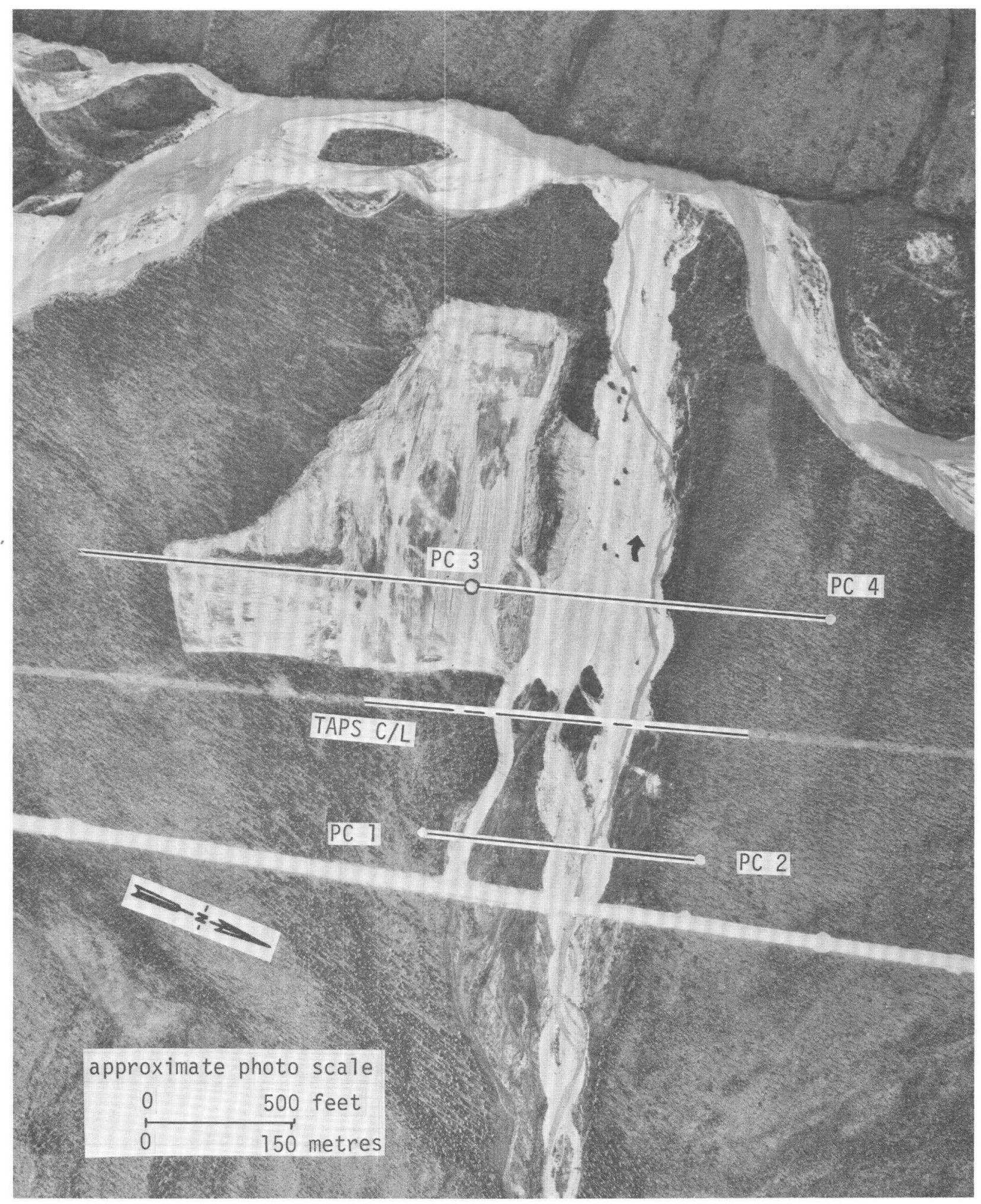

Figure 11. -- Snowden Creek near Dietrich Camp, August 6, 1974. AIR PHOTO TECH. 


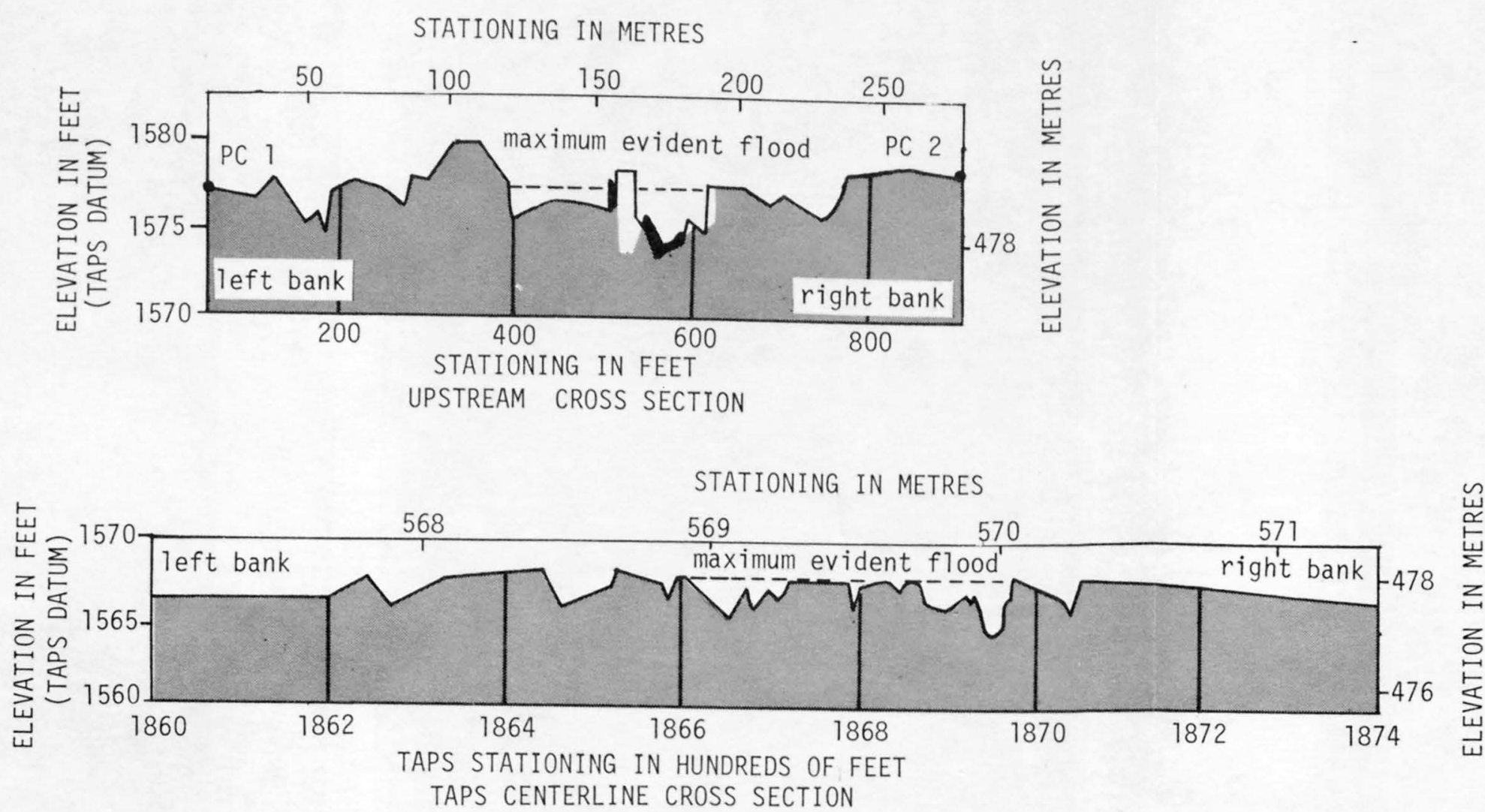

BLACK aREAS INDICATE DEPOSITION,

CLEAR AREAS INDICATE EROSION.

TAPS CENTERLINE CROSS SECTION

STATIONING IN METRES

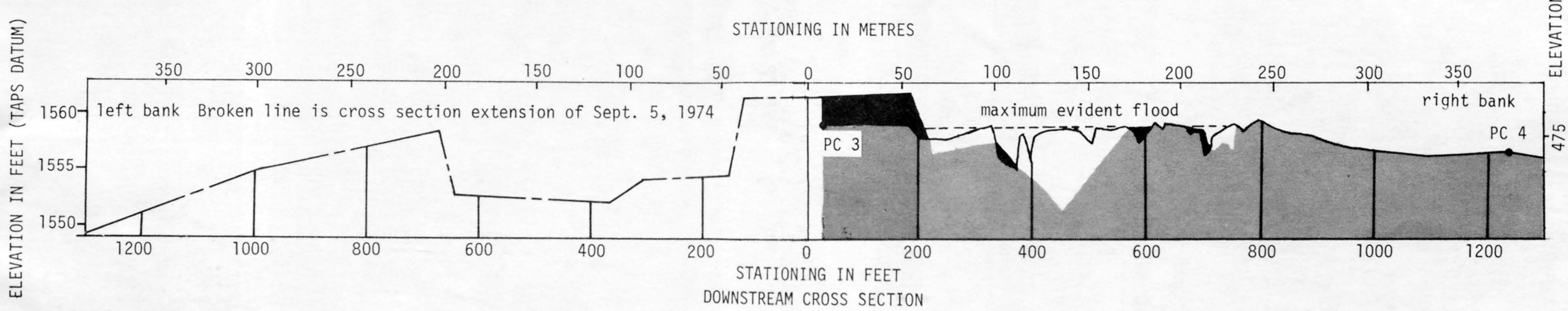

Figure 12. -- Cross sections of Snowden Creek near Dietrich Camp, July 26, 1971 and September 5, 1974 


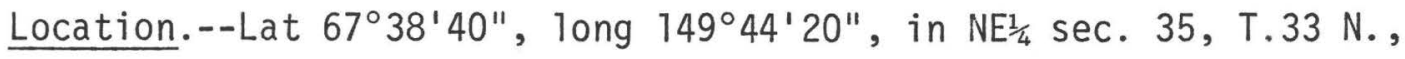
R. 10 W., $0.5 \mathrm{mi}(0.8 \mathrm{~km})$ upstream from Bettles River, and about $15 \mathrm{mi}(24 \mathrm{~km})$ northeast of Wiseman.

[Chandalar (C-6) 1:63,360, U.S. Geological Survey map.]

Channel conditions.--Low-altitude vertical aerial stereophotography (scale 1:2,400) was obtained September 28, 1971, (fig. 13) to document preconstruction topography at the site. Vertical aerial stereophotography (scale 1:6,000) taken August 6, 1974, (fig. 14) shows a bridge and roadway fill construction encroaching into the flood plain along the preconstruction road centerline section. The three cross sections (fig. 15) surveyed July 29, 1971, showed significant changes when they were resurveyed on September 5, 1974. The upstream section shows $10 \mathrm{ft}(3 \mathrm{~m})$ of lateral bank erosion. The preconstruction road centerline section was significantly changed by bridge and roadway fill construction encroaching into the flood plain. Although no overbank flooding occurred during the period July 29, 1971, through September 5, 1974, about $50 \mathrm{ft}$ $(15 \mathrm{~m})$ of lateral. erosion was detected in the main channel of the downstream section. The bridge upstream of this section has constricted the floodflow and concentrated streamflow in the main channel below the bridge.

Floods.--No significant overbank floods occurred during the period of the erosion investigation July 29, 1971, through September 5, 1974. 



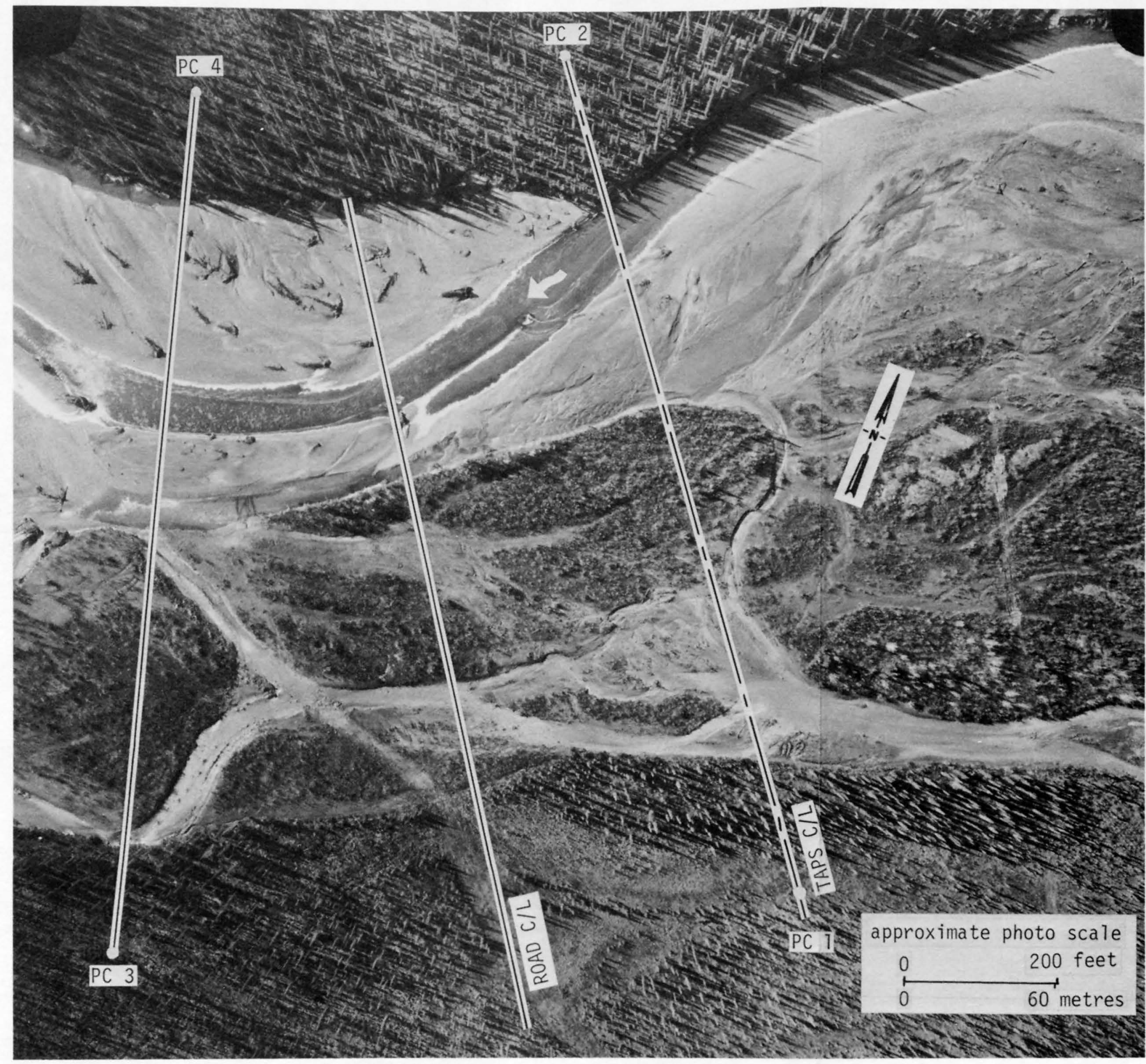

Figure 13. -- Dietrich River at Bettles River, September 28, 1971. WALKER-ALASKA INC. 


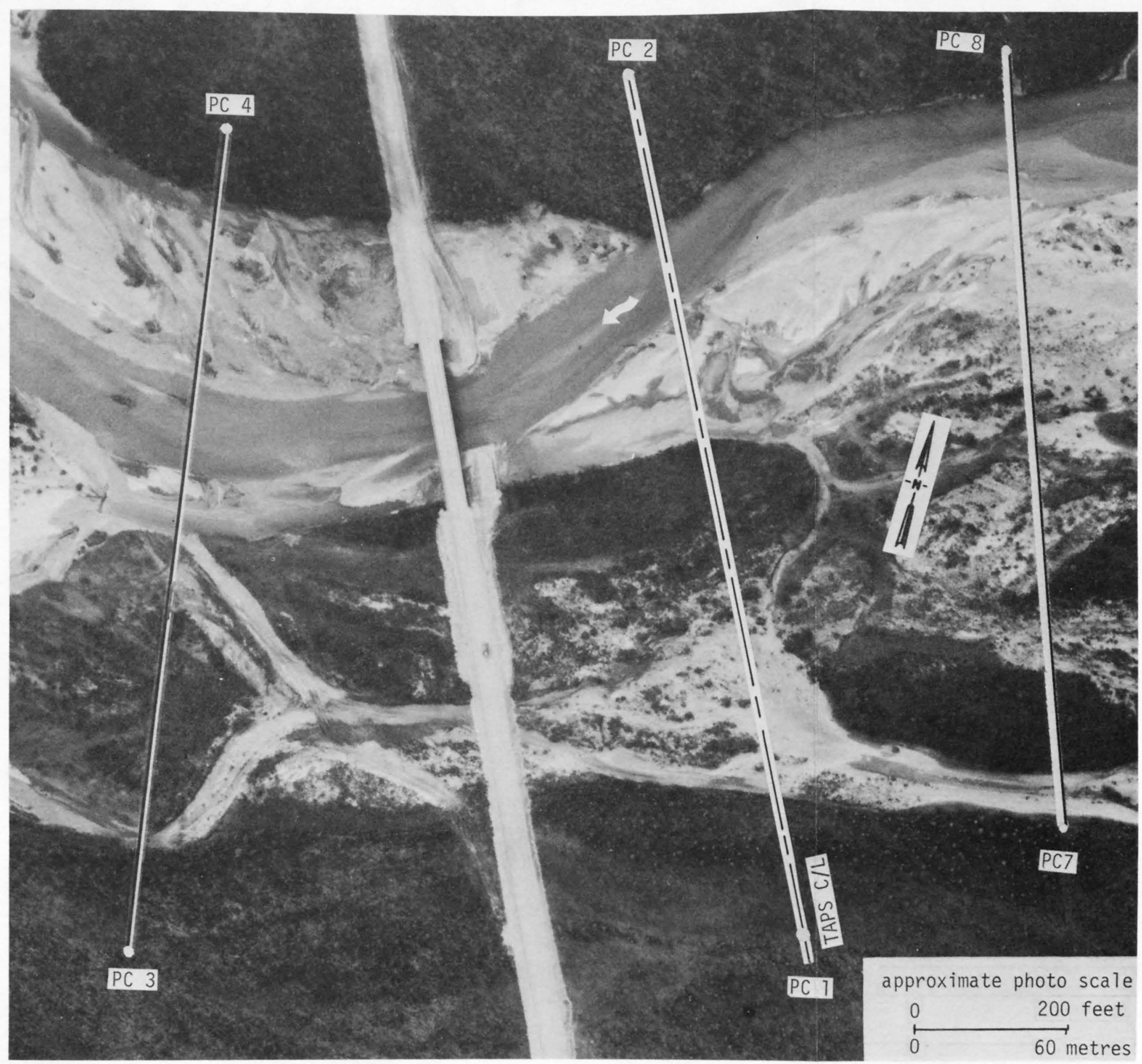

Figure 14. -- Dietrich River at Bettles River, August 6, 1974. AIR PHOTO TECH. 
STATIONING IN METRES

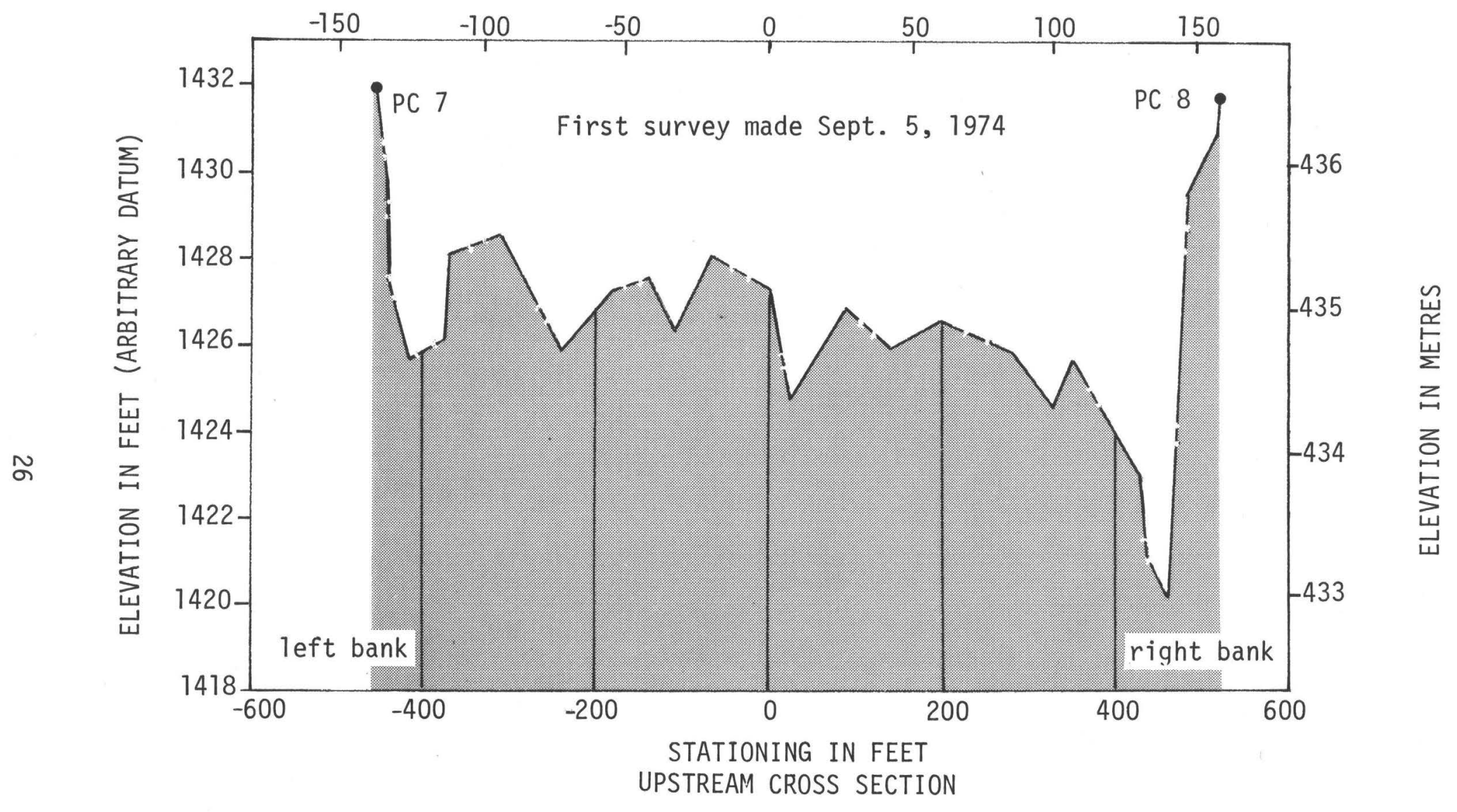

Figure 15.-- Cross sections of Dietrich River at Bettles River, July 29, 1971 and September 5, 1974. 
STATIONING IN METRES

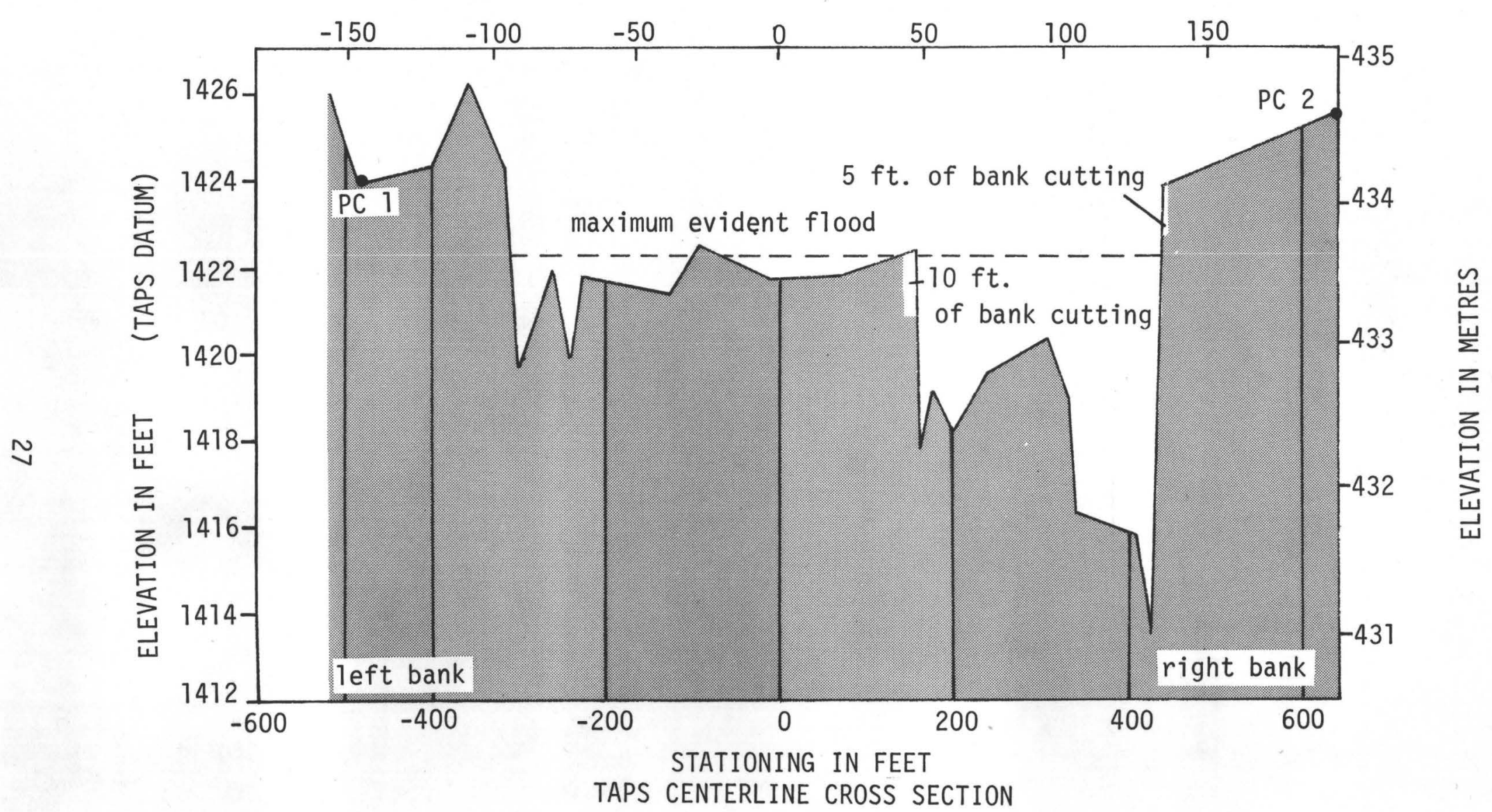

Figure 15.-- Cross sections of Dietrich River at Bettles River, July 29, 1971 and September 5 , 1974 -Continued. 
STATIONING IN METRES

N

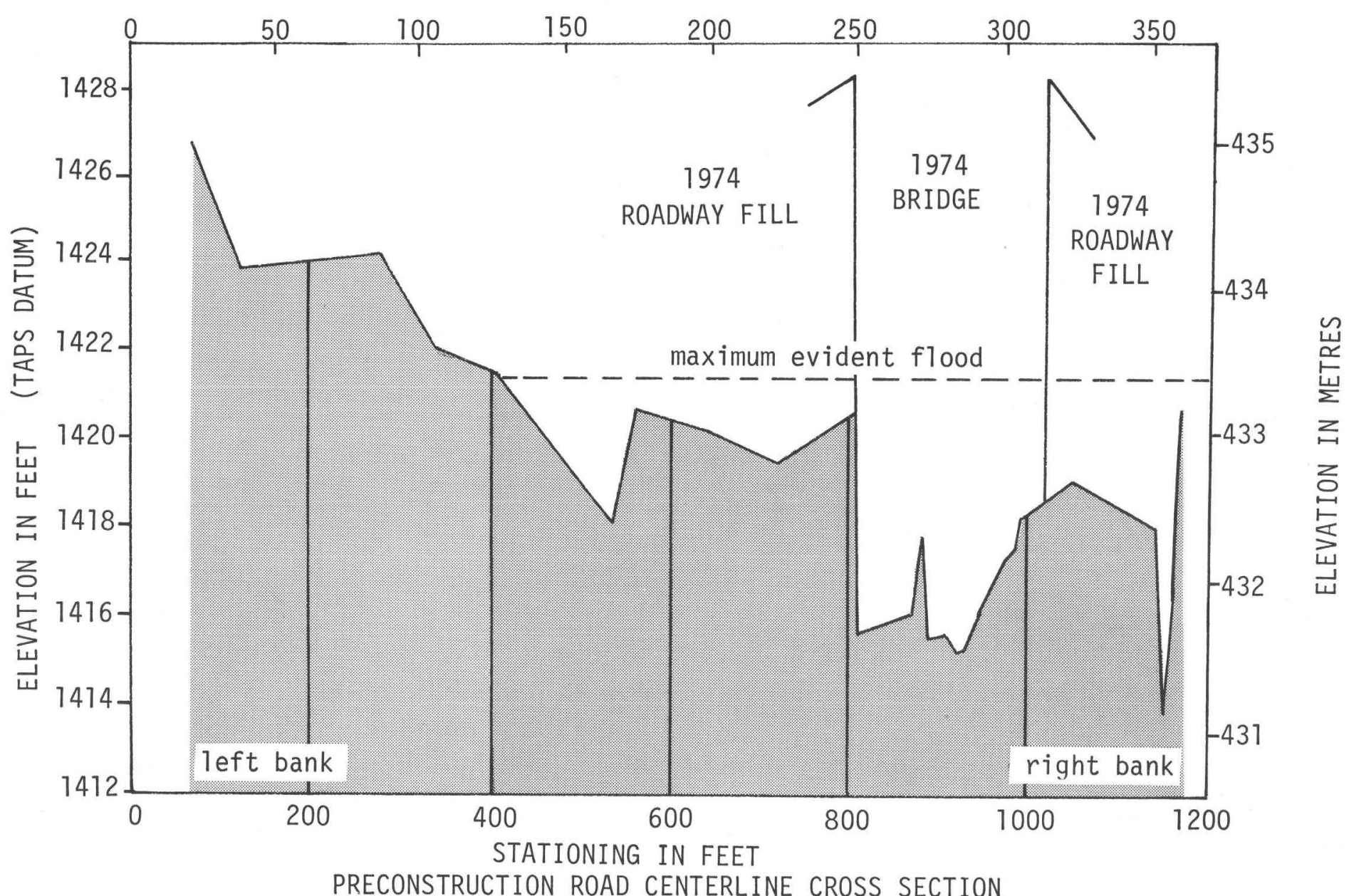

Figure 15.-- Cross sections of Dietrich River at Bettles River, Ju1y 29, 1971 and September 5 , 1974 -Continued. 
STATIONING IN METRES

กั

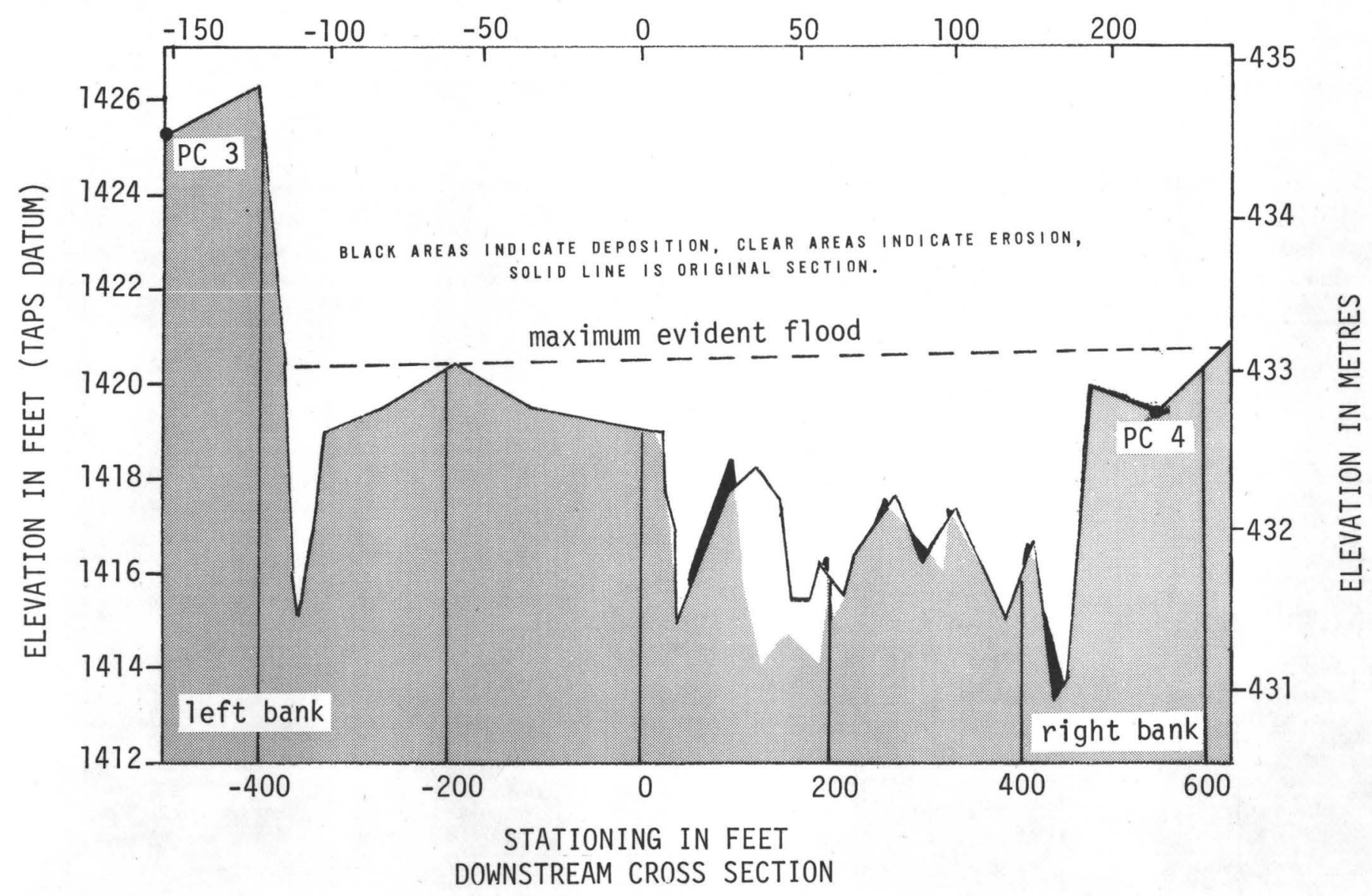

Figure 15.-- Cross sections of Dietrich River at Bettles River, July 29, 1971 and September 5, 1974 -Continued. 
Middle Fork Koyukuk River at Hammond River

Location.--Lat $67^{\circ} 27^{\prime} 45^{\prime \prime}$, long $150^{\circ} 01^{\prime} 20^{\prime \prime}$, in SW/ sec.33, T.31 N.,

R. 11 W., $0.3 \mathrm{mi}(0.5 \mathrm{~km})$ upstream from Hammond River, and $4.3 \mathrm{mi}$ $(6.9 \mathrm{~km})$ northeast of Wiseman.

[Wiseman (B-1) 1:63,360, U.S. Geological Survey map.]

Channel conditions.--Low-altitude vertical aerial stereophotography (scale 1:4,800) was obtained September 28, 1971, (fig. 16) to document preconstruction topography at the site. Vertical aerial strip photography (scale 1:6,000) taken September 1, 1974, (fig. 17) shows a bridge and roadway fill being constructed at the downstream cross section below the TAPS centerline cross section. The overflow channel on the far left bank of the TAPS centerline cross section has been diked off upstream at the material-removal site and by the road embankment. Three cross sections (fig. 18) were surveyed Ju1y 27, 1971, to define preconstruction ground profiles in the crossing reach. On September 5, 1974, a channel survey of the upstream cross section found no significant latera 1 erosion.

Floods.--No significant overbank floods occurred during the period of the erosion investigation Ju1y 25, 1971, through September 5, 1974. 


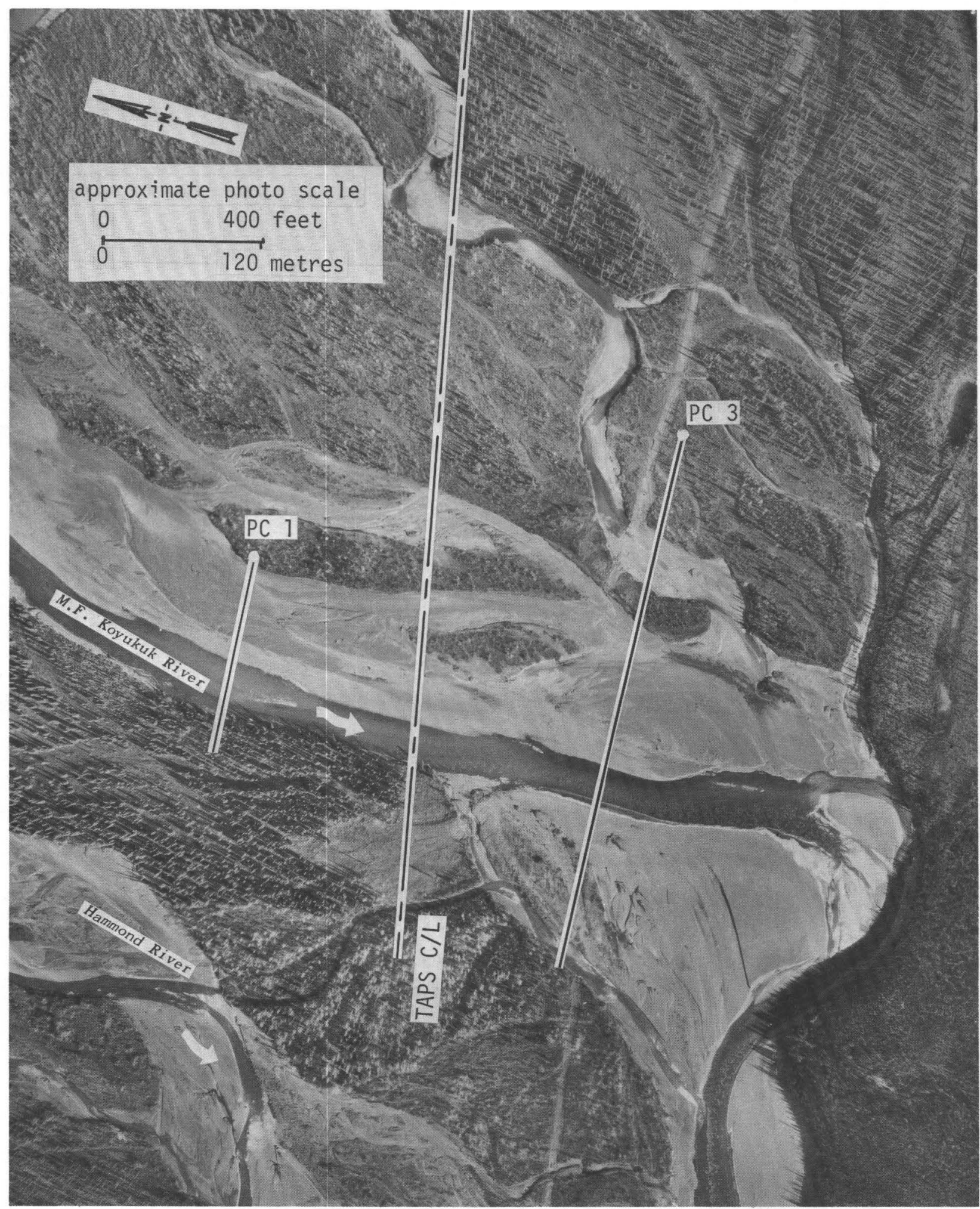

Figure 16. -- Middle Fork Koyukuk River at Hammond River, September 28, 1971. WALKER-ALASKA INC. 


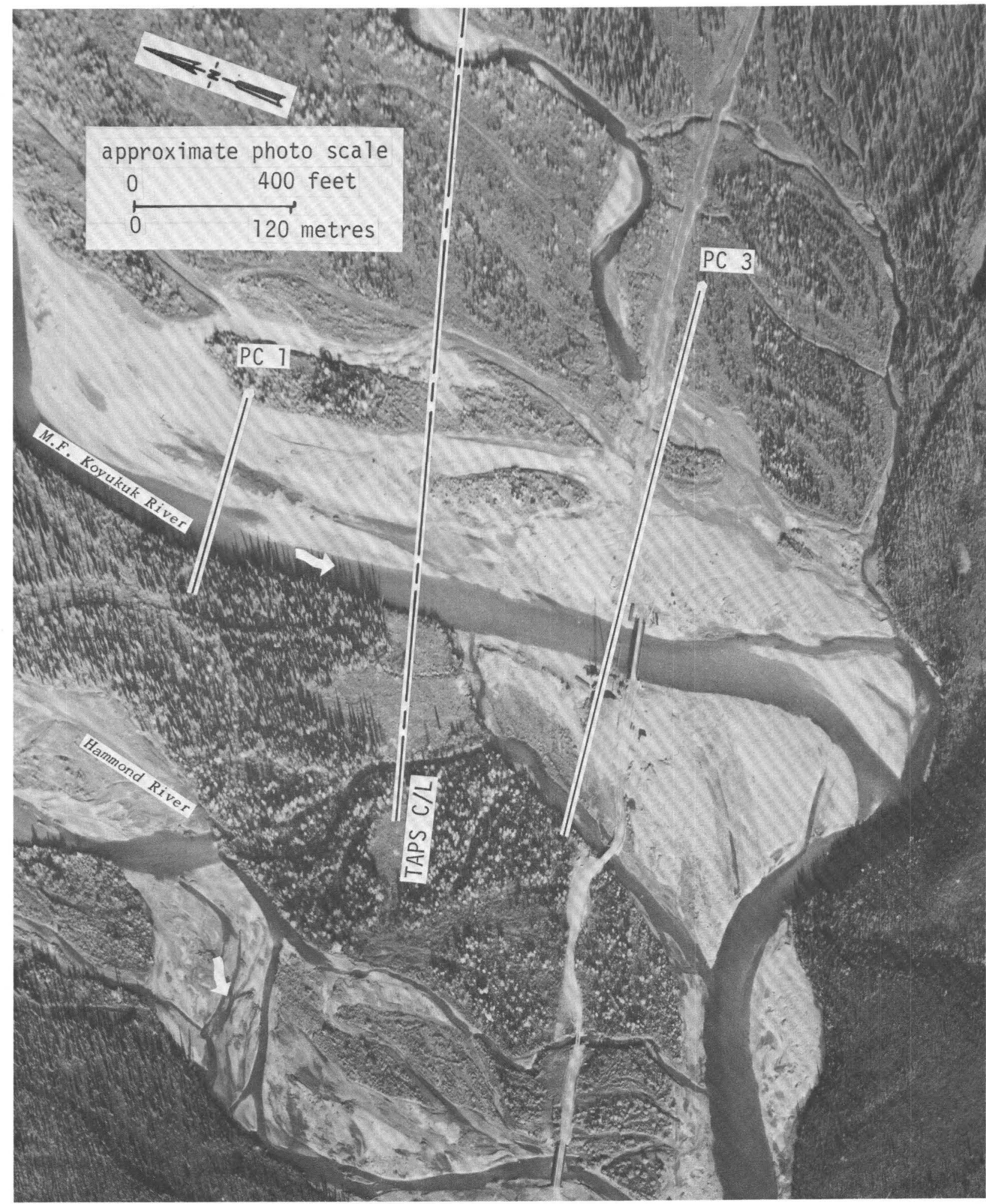

Figure 17. -- Middle Fork Koyukuk River at Hammond River, September 1, 1974. ALYESKA PIPELINE SERVICE CO.-AIR PHOTO TECH. 

STATIONING IN METRES

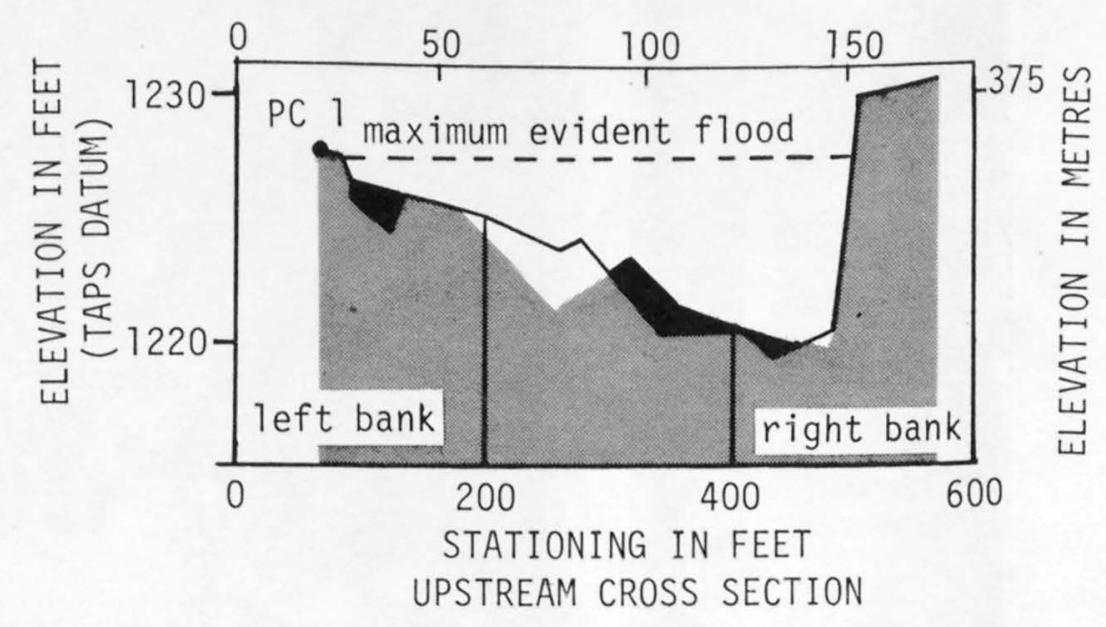

BLACK AREAS INOICATE DEPOSITION,

OR AREAS INDICATE EROSION,

SOLID LINE IS ORIGINAL SECTION.

STATIONING IN METRES

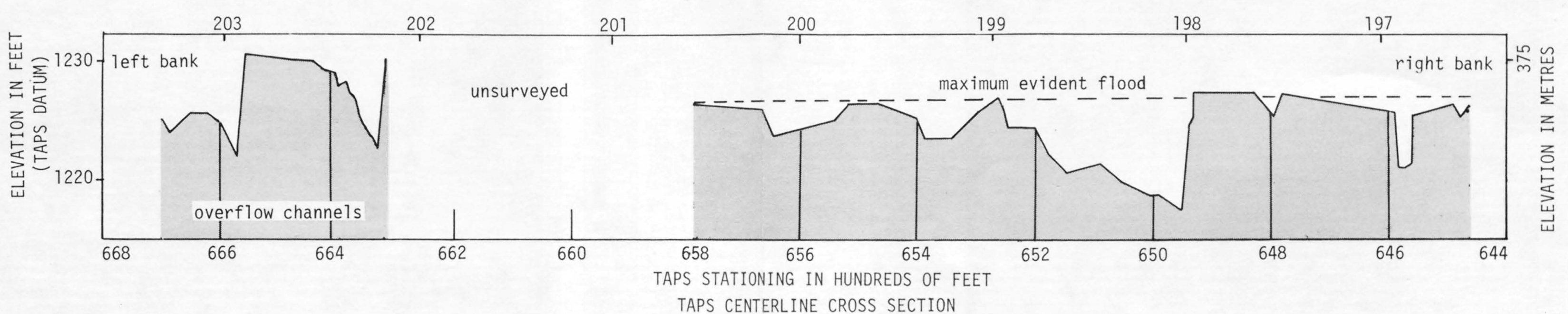

STATIONING IN METRES

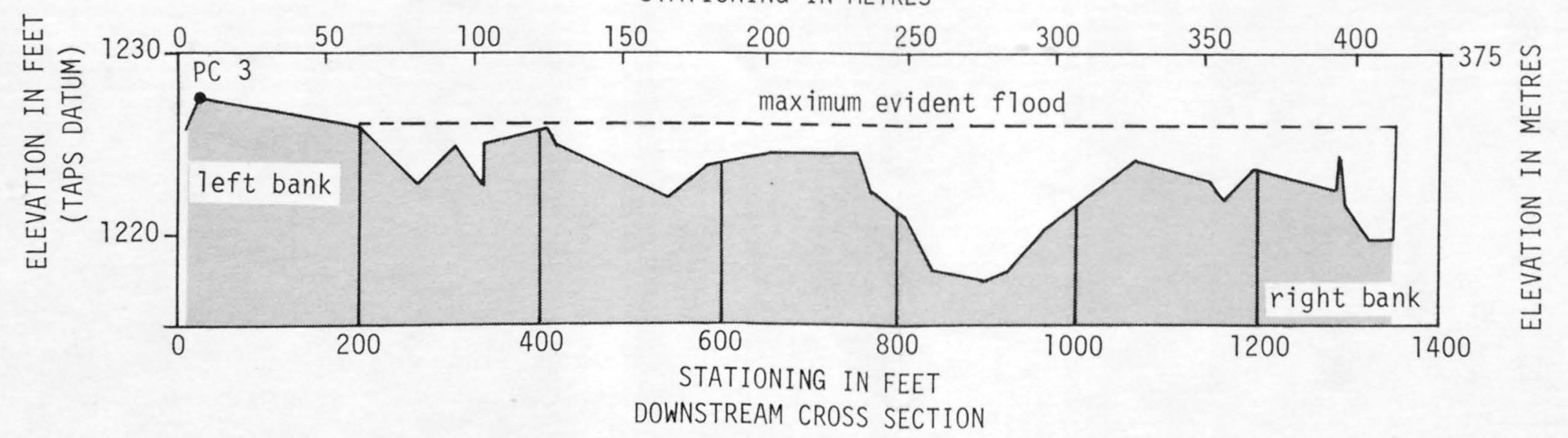

Figure 18. -- Cross sections of Middle Fork Koyukuk River at Hammond River, July 27, 1971 and September 5 , 1974. 


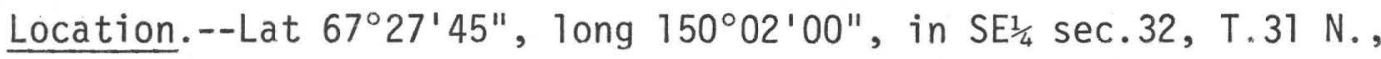
R.11 W., $0.3 \mathrm{mi}(0.5 \mathrm{~km})$ upstream from Hammond River, and $4.3 \mathrm{mi}$ $(6.9 \mathrm{~km})$ northeast of Wiseman.

[Wiseman (B-1) 1:63,360, U.S. Geological Survey map.]

Channel conditions.--Low-altitude vertical aerial stereophotography (scale 1:4,800) was obtained September 28, 1971, (fig. 19) to document preconstruction topography at the site. Vertical aerial strip photography (scale 1:6,000) taken September 1, 1974, (fig. 20) shows bridge and roadway fill being constructed near the downstream cross section below the TAPS centerline cross section. Three cross sections (fig. 21) were surveyed Ju1y 25, 1971, to define preconstruction ground profiles in the crossing reach. On September 5, 1974, a channel survey showed about $20 \mathrm{ft}(6 \mathrm{~m})$ of lateral bank erosion in the upstream section and $20 \mathrm{ft}(6 \mathrm{~m})$ of lateral bank erosion in the downstream section along the right bank. About $2 \mathrm{ft}(0.6 \mathrm{~m})$ of scour has occurred along the right cutbank in the upstream section.

Floods.--No significant overbank floods occurred during the period of the erosion investigation Ju1y 25, 1971, through September 5, 1974. 


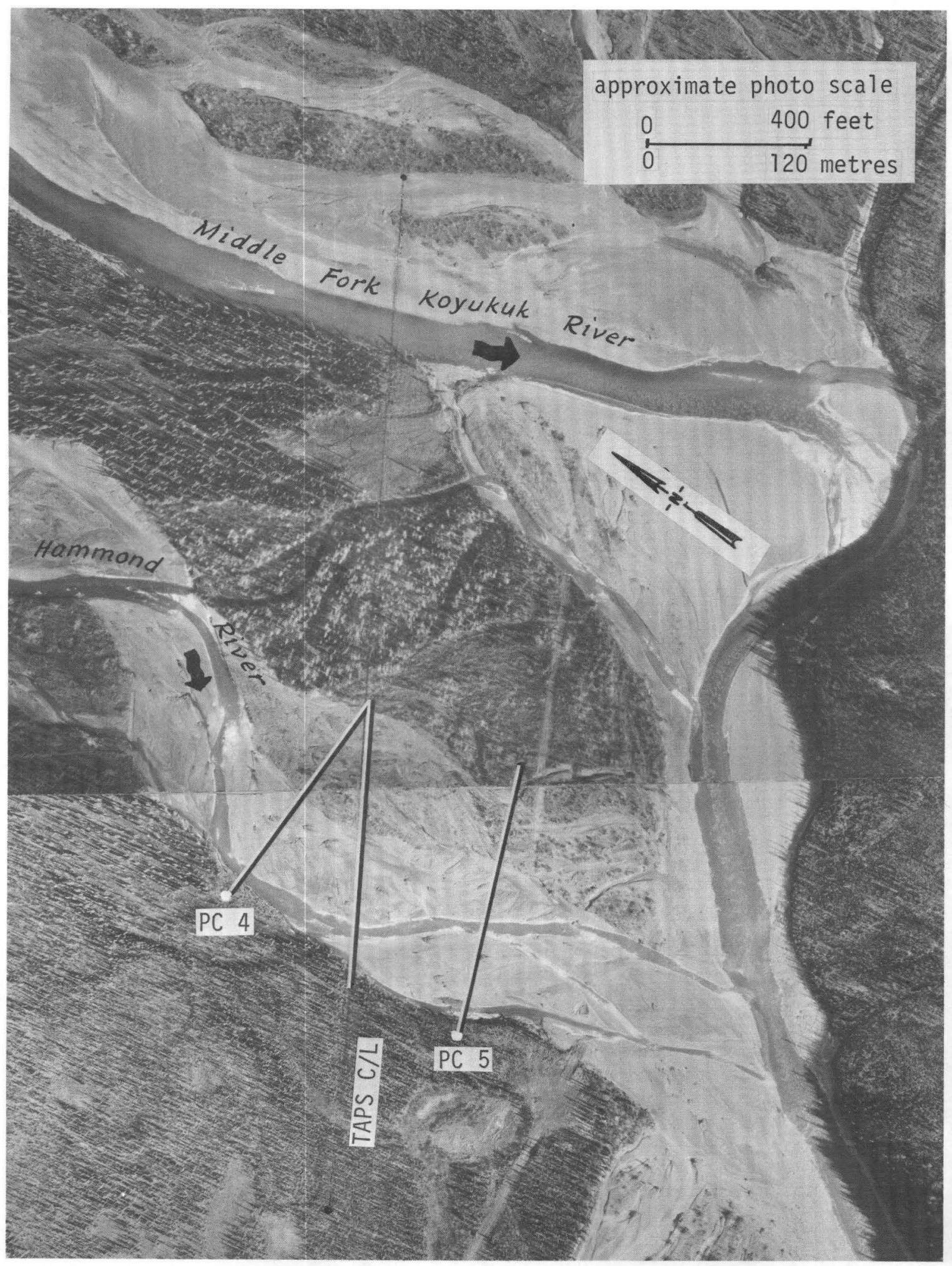

Figure 19. -- Hammond River near Wiseman, September 28, 1971. WALKER-ALASKA INC. 


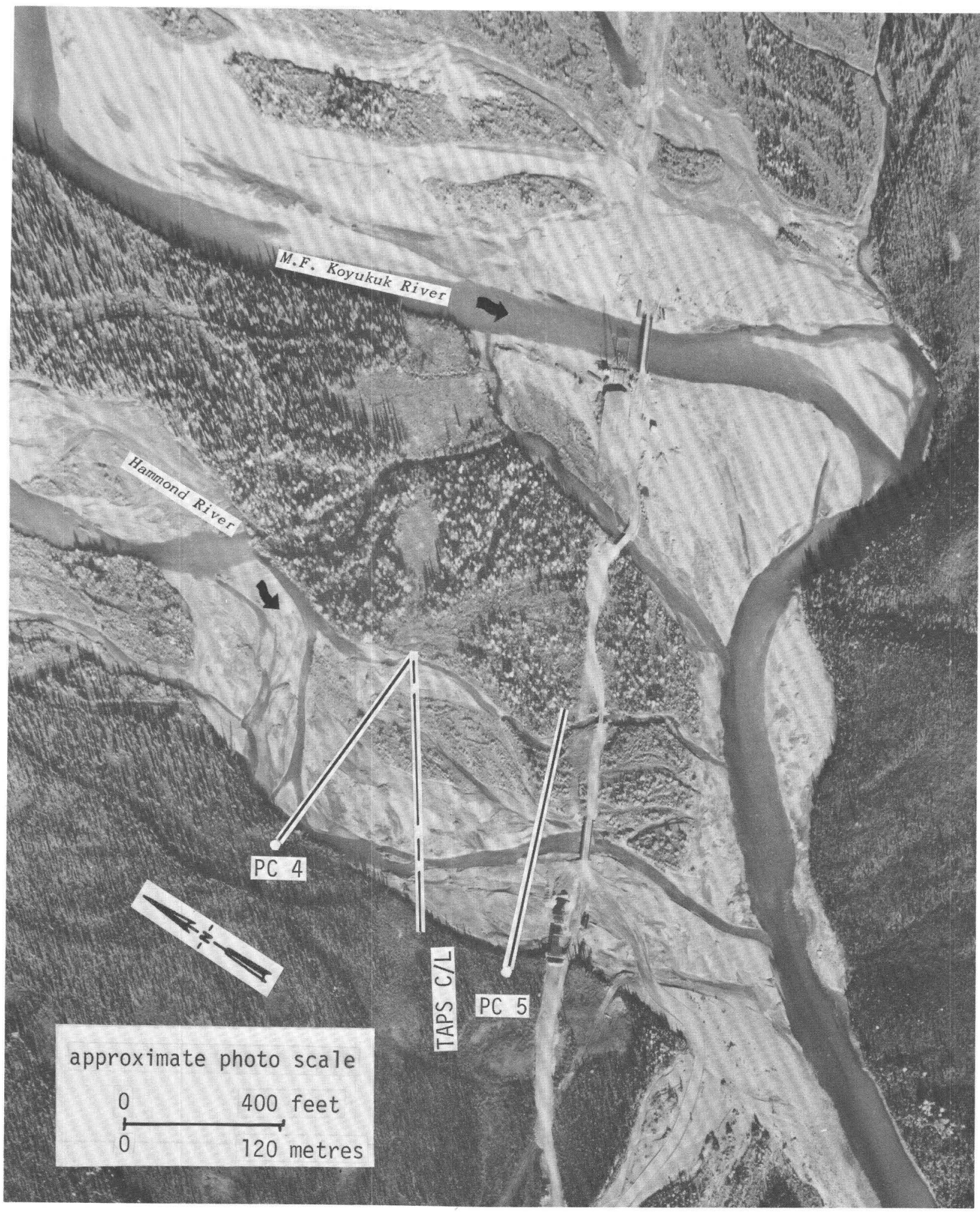

Figure 20. -- Hammond River near Wiseman, September 1, 1974. ALYESKA PIPELINE SERVICE CO.-AIR PHOTO TECH. 
STATIONING IN METRES

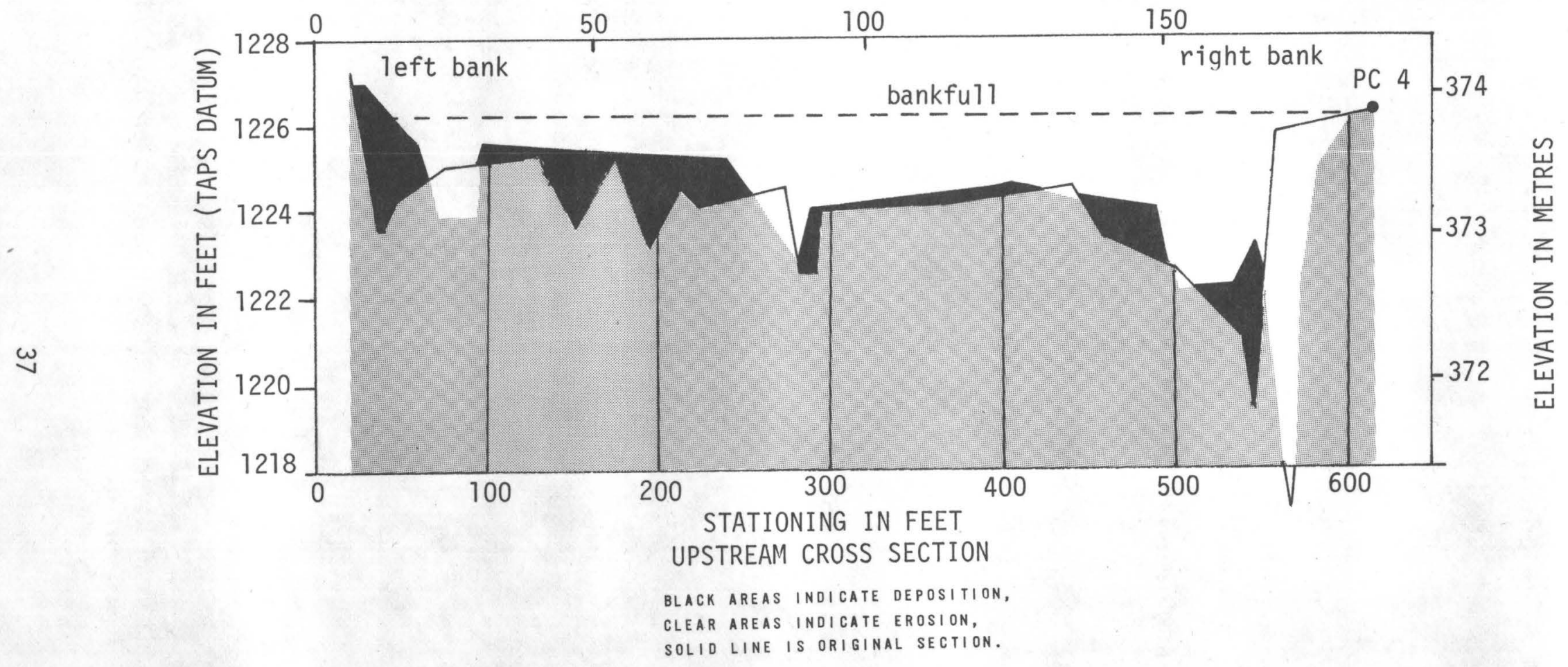

Figure 21.-- Cross sections of Hammond River near Wiseman, Ju1y 25, 1971 and September 5, 1974. 


\section{STATIONING IN METRES}

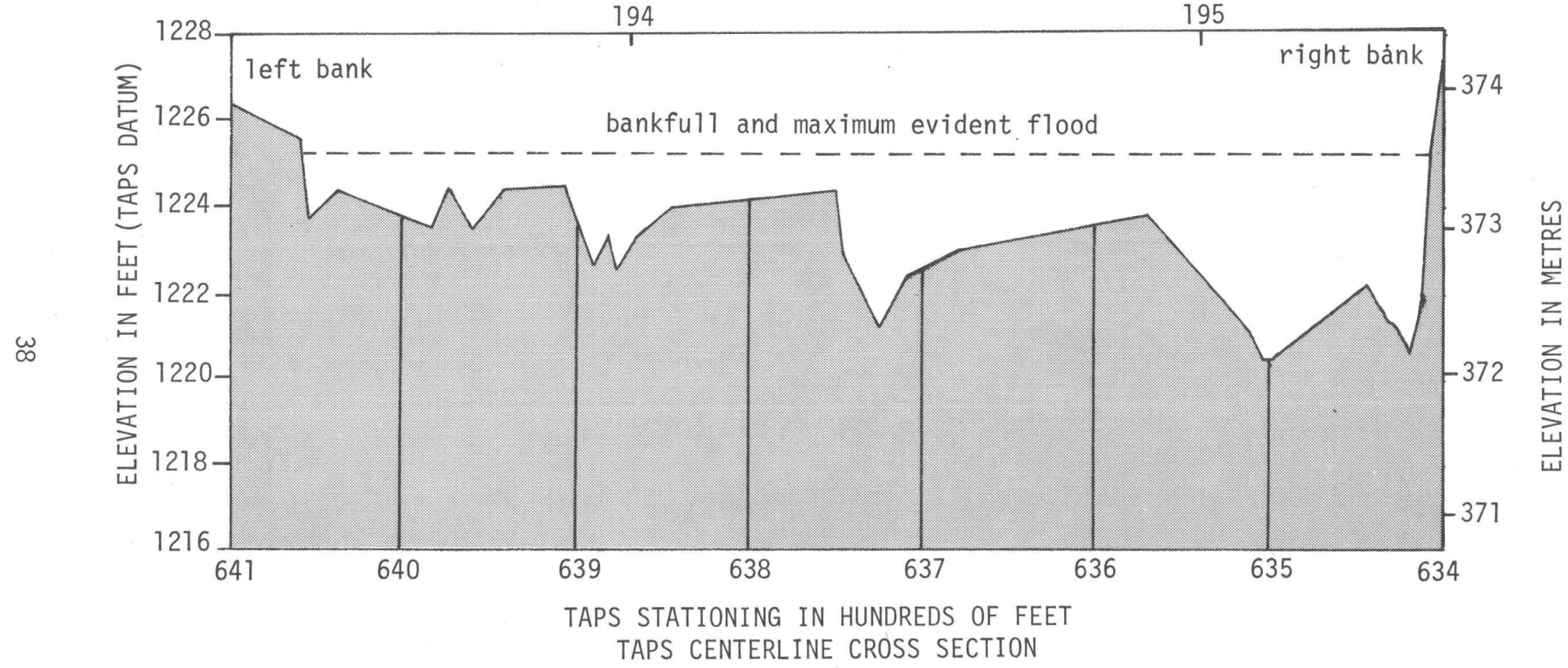

Figure 21.-- Cross sections of Hammond River near Wiseman, Ju1y 25, 1971 and September 5, 1974-Continued. 
STATIONING IN METRES

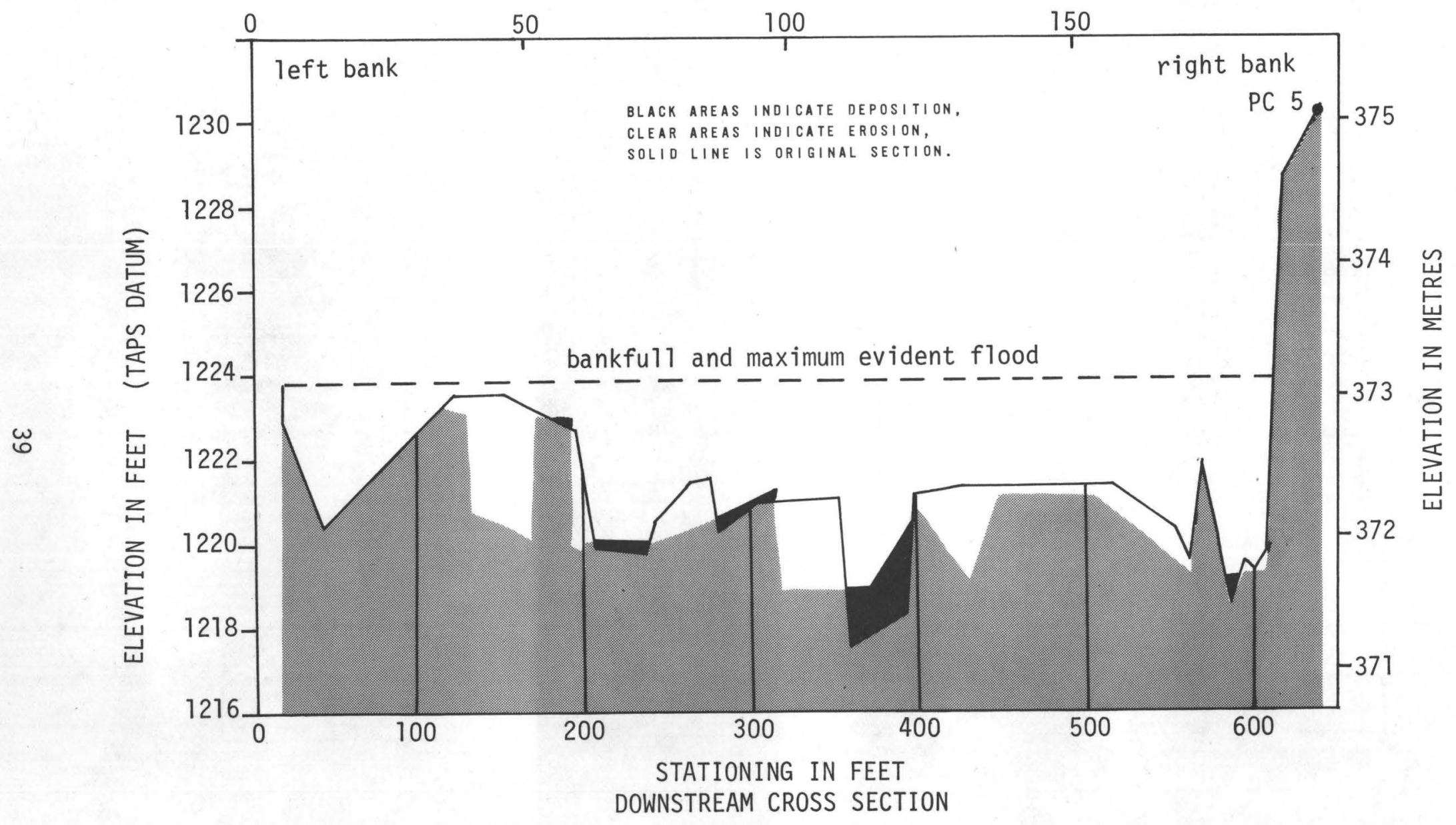

Figure 21.-- Cross sections of Hammond River near Wiseman, July 25, 1971 and September 5, 1974 -Continued. 


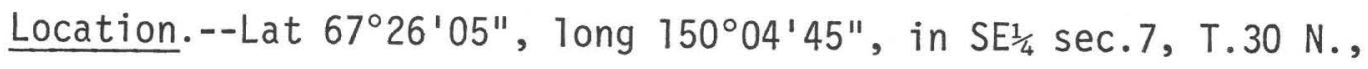
R.11 W., $1.5 \mathrm{mi}(2.4 \mathrm{~km})$ upstream from Wiseman, and $2.5 \mathrm{mi}(4.0 \mathrm{~km})$ downstream from the Hammond River.

[Wiseman (B-1) 1:63,360, U.S. Geological Survey map.]

Channel conditions.--Low-altitude vertical aerial stereophotography (scale 1:4,800) was obtained September-28, 1971, (fig. 22) to document preconstruction topography at the site. Vertical aerial stereophotography (scale 1:6,000) taken August 6, 1974, (fig. 23) shows bridge and roadway fill being constructed $800 \mathrm{ft}(240 \mathrm{~m})$ above the upstream cross section. The roadway fill encroaches on the flood plain on both banks and forms a dike along the left bank overflow channel. Three cross sections (fig. 24) were surveyed July 27, 1971, to define preconstruction ground profiles in the crossing reach. The channel survey of September 4, 1974, of the upstream and downstream cross sections found no significant lateral bank erosion and about $2 \mathrm{ft}(0.6 \mathrm{~m})$ of scour.

Floods.--On August 21, 1974, a floodpeak discharge, 17,100 ft3/s (484 $\mathrm{m}^{3} / \mathrm{s}$ ) (fig. 25$)$, occurred at a stage of about $2 \mathrm{ft}(0.6 \mathrm{~m})$ below the maximum evident flood. 


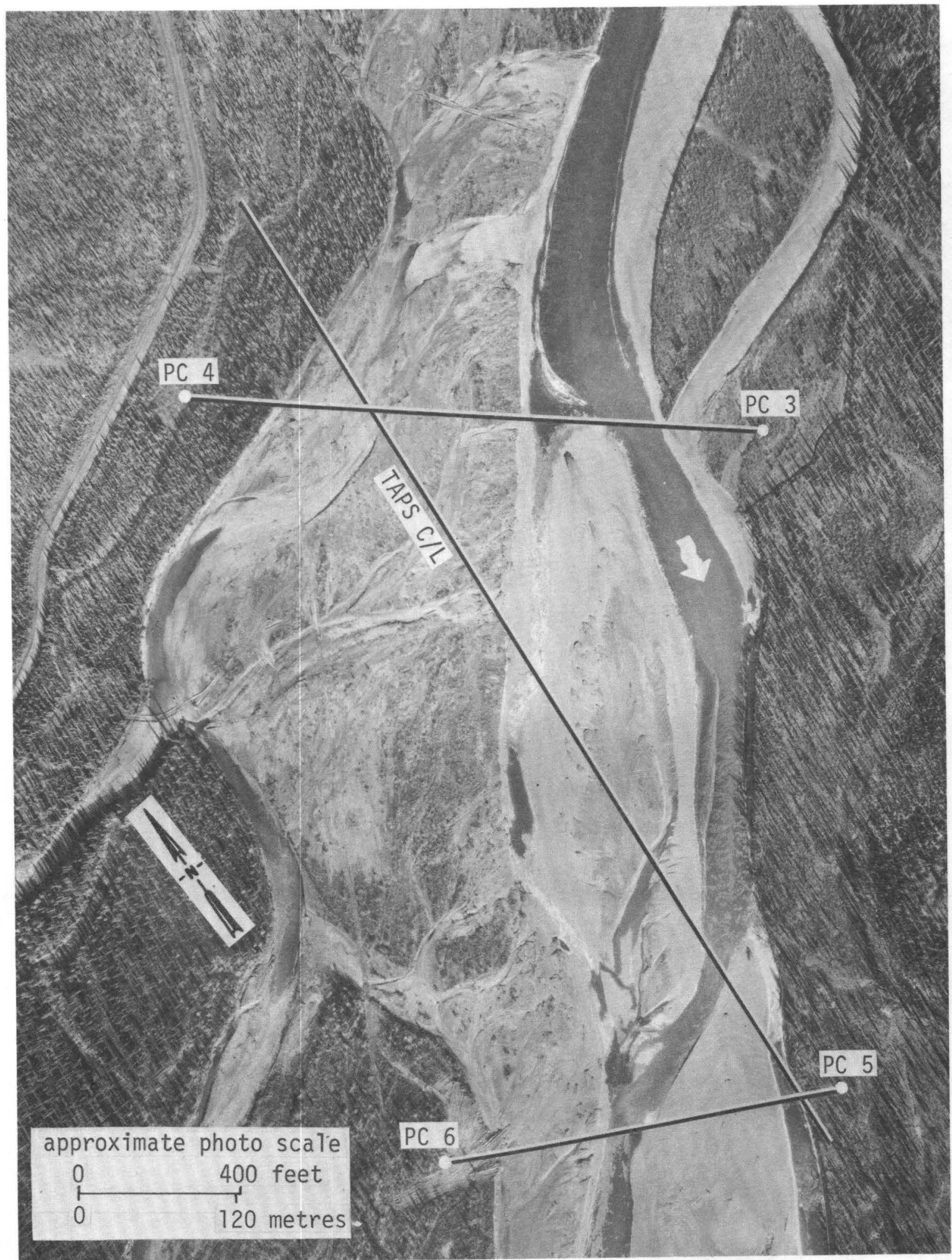

Figure 22. -- Middle Fork Koyukuk River near Wiseman, September 28, 1971. WALKER-ALASKA INC. 


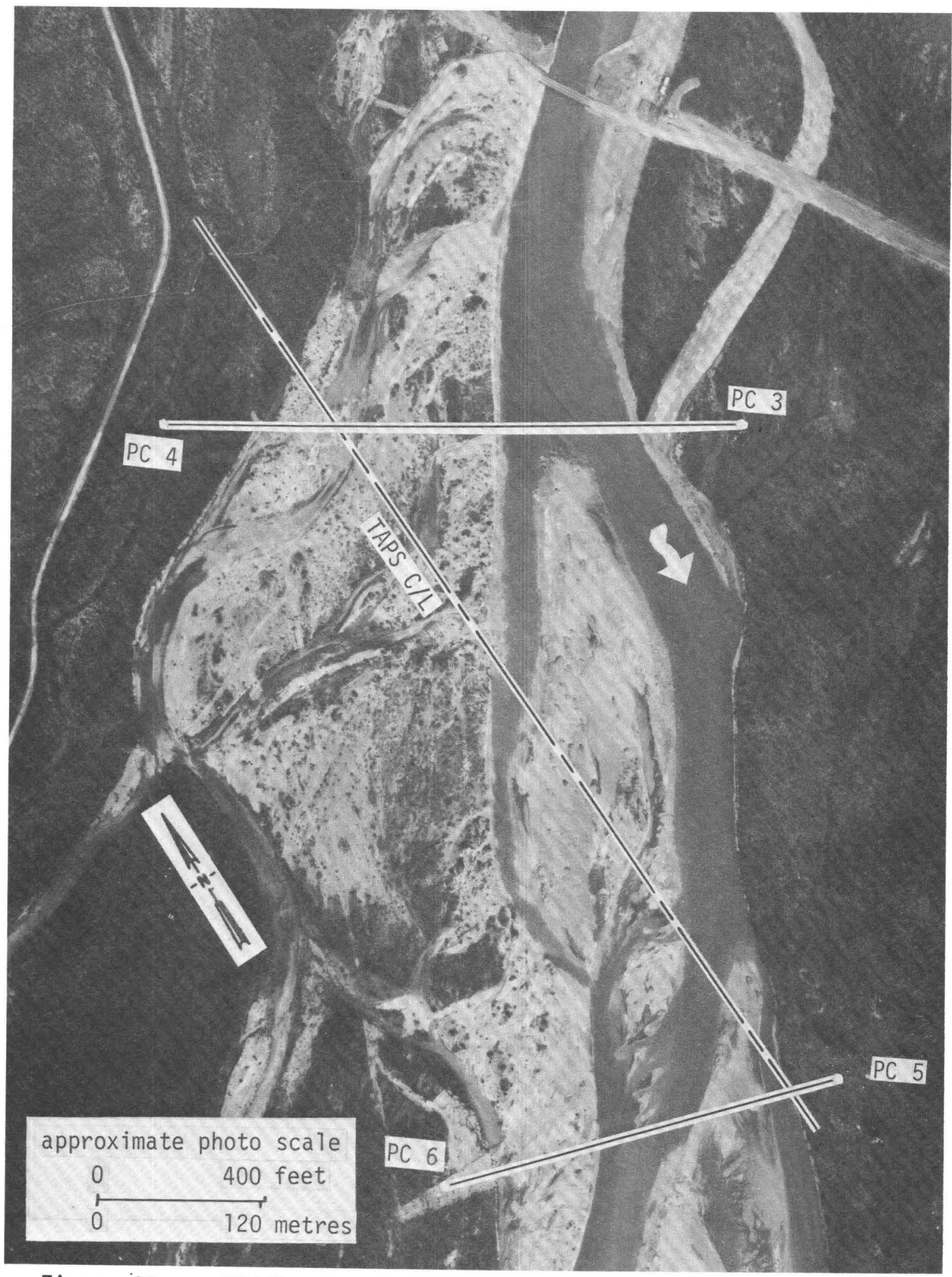

Figure 23. -- Middle Fork Koyukuk River near Wiseman, August 6, 1974. AIR PHOTO TECH. 


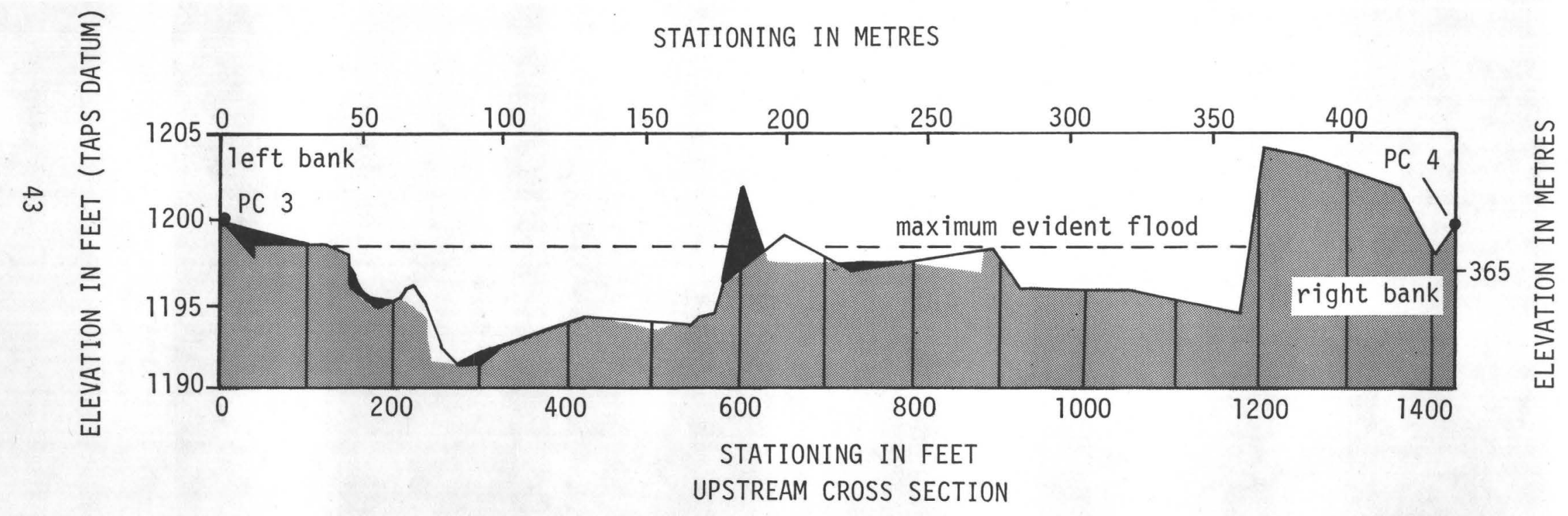

BLACK AREAS INDICATE DEPOSITION, CLEAR AREAS INDICATE EROSION, SOLIO LINE IS ORIGINAL SECTION.

Figure 24.-- Cross sections of Middle Fork Koyukuk River near Wiseman, July 27, 1971, and September 4, 1974. 
STATIONING IN METRES

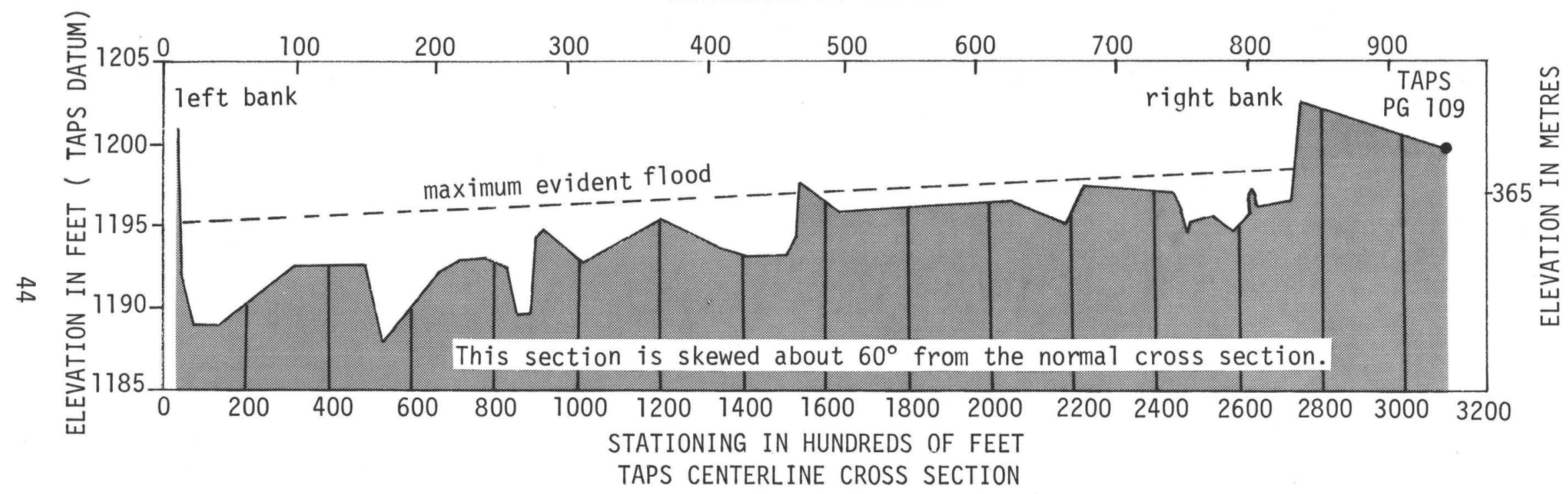

Figure 24. -- Cross sections of Middle Fork Koyukuk River near Wiseman, Ju1y 27, 1971 and September 4, 1974 -- Continued. 


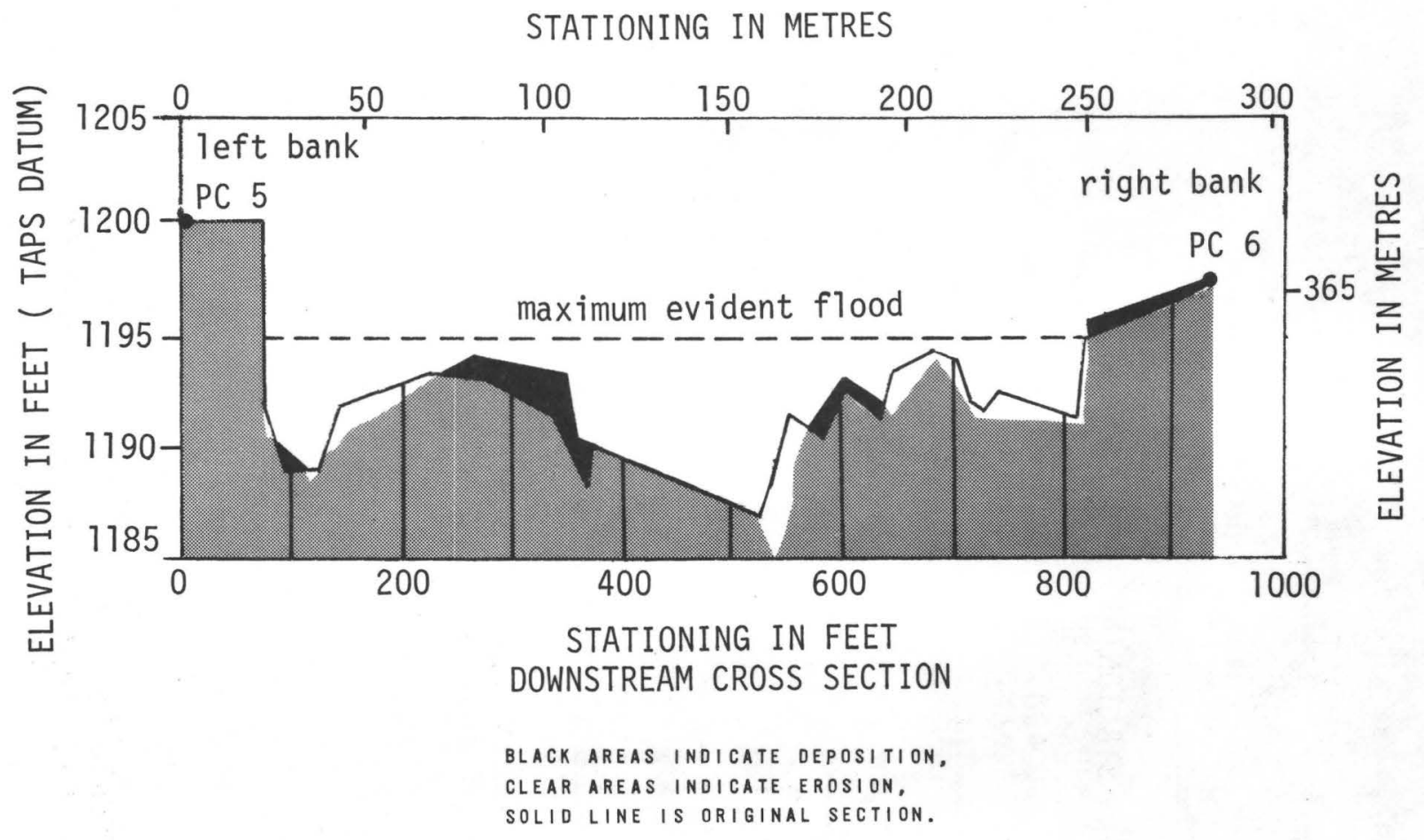

Figure 24. -- Cross sections of Middle Fork Koyukuk River near Wiseman, July 27, 1971 and September 4, 1974 -- Continued. 


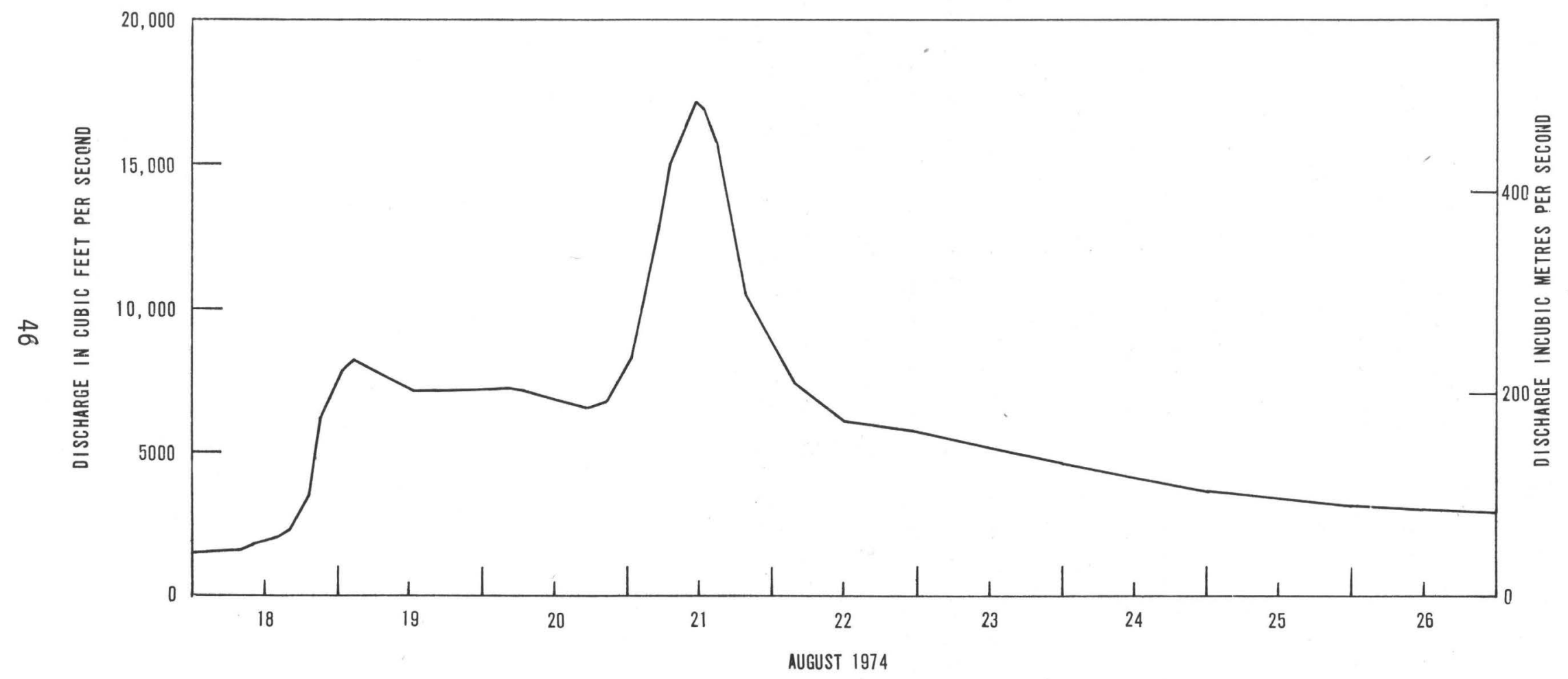

Figure 25.-- Discharge hydrograph for Middle Fork Koyukuk River near Wiseman. 
Location.--Lat $67^{\circ} 01^{\prime} 10^{\prime \prime}$, long $150^{\circ} 16^{\prime} 40^{\prime \prime}$, in SW/ $\frac{1}{4}$ sec.6, T.25 N., R. 12 W., $11 \mathrm{mi}(18 \mathrm{~km})$ upstream from the Gold Bench Mine, and $40 \mathrm{mi}(64 \mathrm{~km})$ northeast of Bettles.

[Wiseman (A-1) 1:63,360, U.S. Geologica1 Survey map.]

Channel conditions.--Low-altitude vertical aerial stereophotography (scale 1:4,800) was obtained September 28, 1971, (fig. 26) to document preconstruction topography at the site. Vertical aerial stereophotography (scale 1:6,000) taken August 6, 1974, (fig. 27) shows no significant channel erosion or construction activities have occurred in the proposed crossing reach since September 28, 1971. Three cross sections (fig. 28) were surveyed July 22, 1971, and September 26, 1973, to define preconstruction ground profiles in the crossing reach. In September 1974 a channel survey of the three cross sections found no significant lateral erosion.

Floods.--No significant overbank flooding occurred during the period of erosion investigation July 1971 through September 1974. 


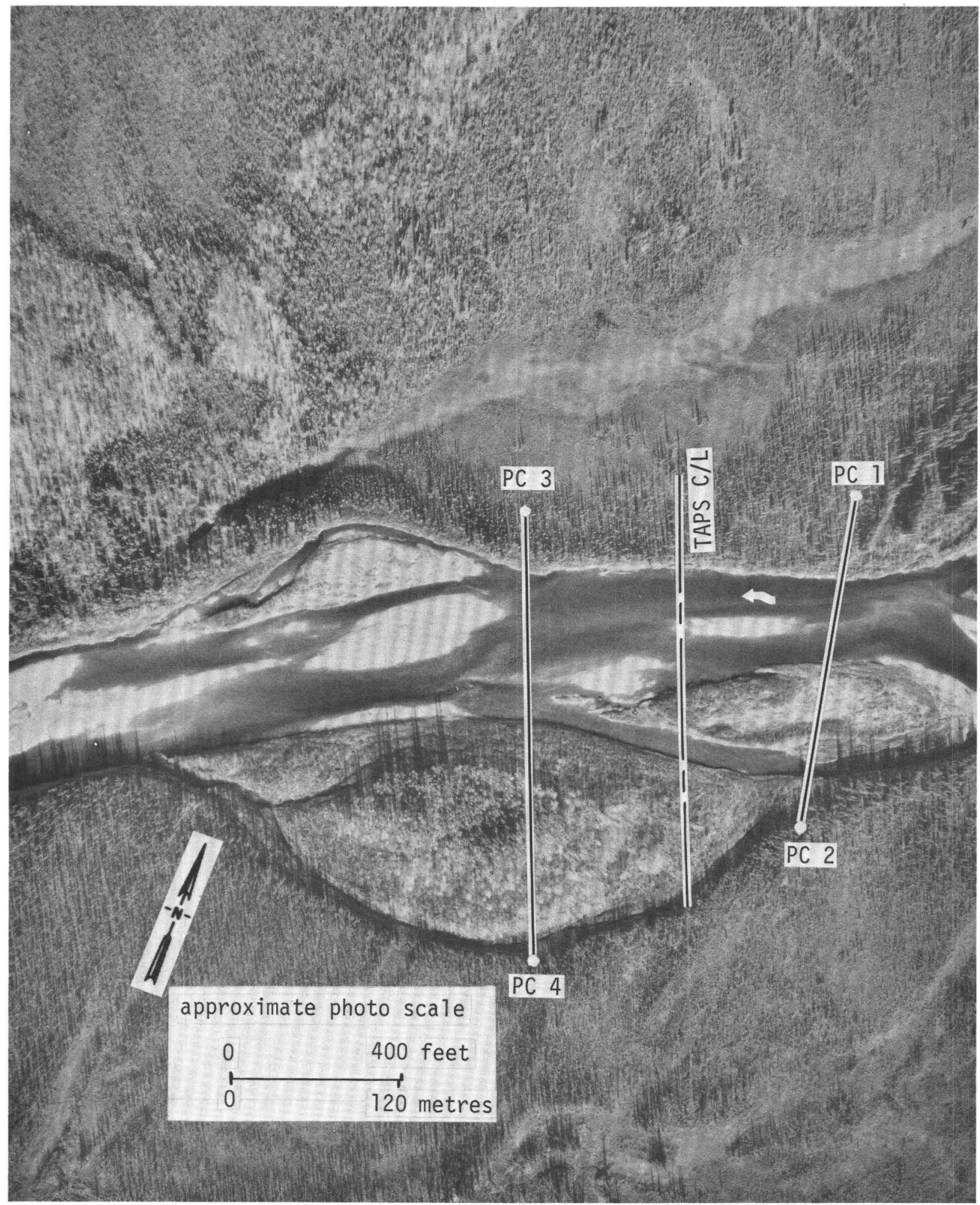

Figure 26. -- South Fork Koyukuk River near Wiseman, September 28, 1971. WALKER-ALASKA INC. 


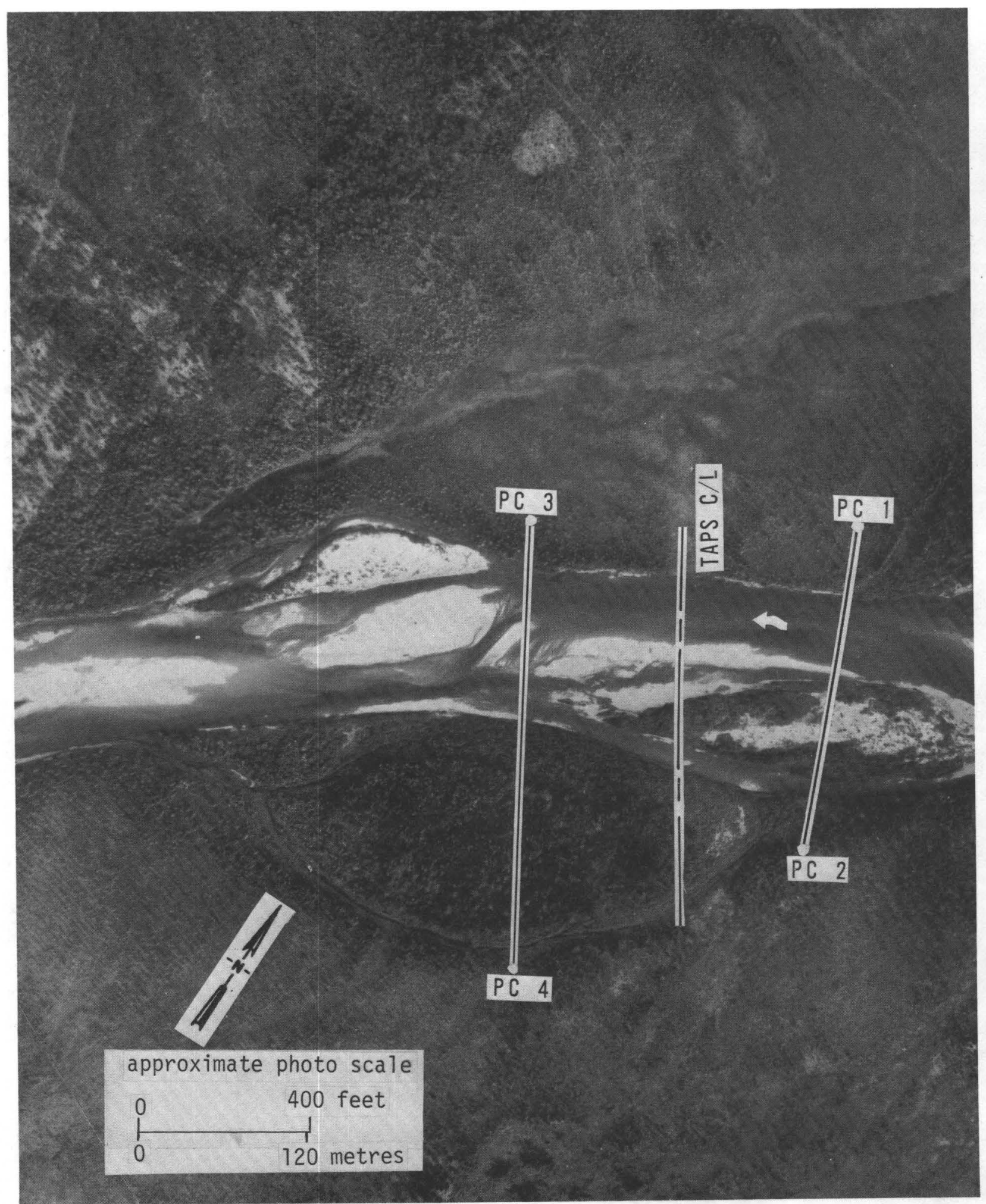

Figure 27. -- South Fork Koyukuk River near Wiseman, August 6, 1974. AIR PHOTO TECH. 
STATIONING IN METRES

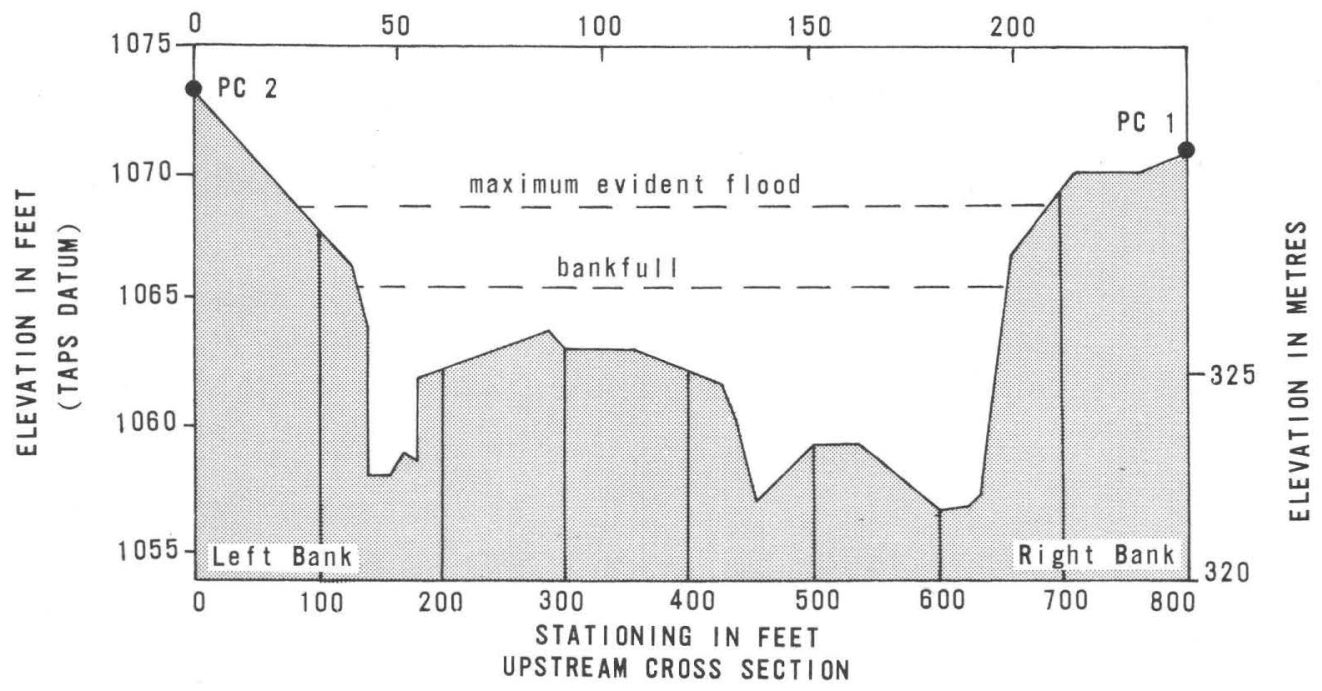

STATIONING IN METRES
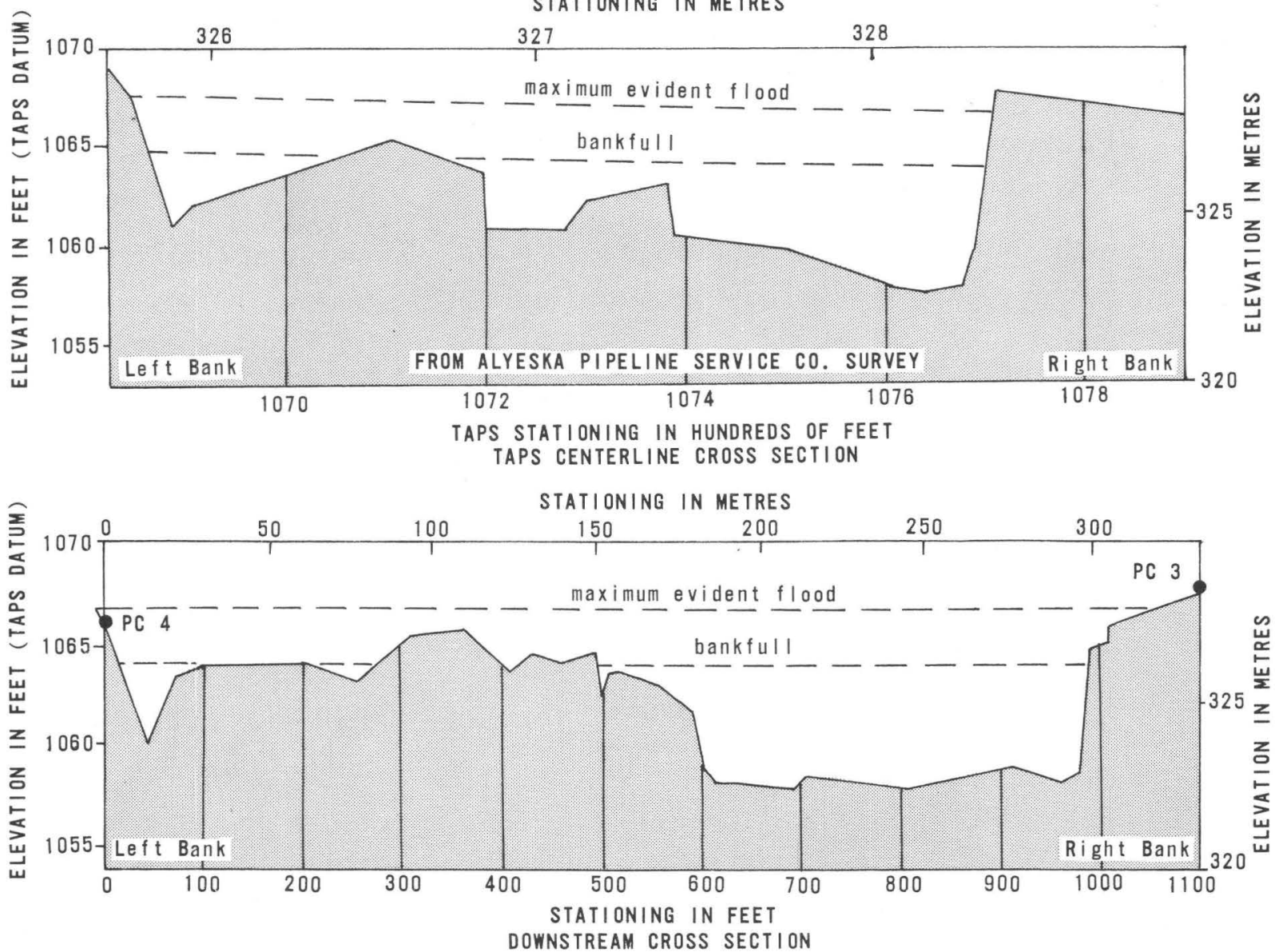

Figure 28. -- Cross sections of South Fork Koyukuk River near Wiseman, Ju1y 22, 1971, and September 26, 1973. 


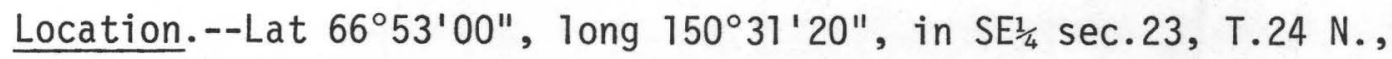
R.14 W., $2.4 \mathrm{mi}(3.9 \mathrm{~km})$ upstream from Douglas Creek, and $32 \mathrm{mi}$ (51 km) east of Bettles Field.

[Bettles (D-2) 1:63,360, U.S. Geological Survey map.]

Channel conditions.--Low-altitude vertical aerial stereophotography (scale 1:2,400) was obtained September 28, 1971, (fig. 29) to document preconstruction topography at the site. Vertical aerial stereophotography (scale 1:6,000) taken August 25, 1974, (fig. 30) shows bridge and road fill being constructed near the downstream cross section. The photographs show no significant lateral erosion. Three cross sections (fig. 31) were surveyed July 20, 1971, to define preconstruction ground profiles in the crossing reach. On September 1974 a channel survey of the preconstruction cross sections showed no significant change.

Floods.--No significant overbank flooding occurred during the period July 20, 1971, through September 1974. The maximum observed discharge for the period was confined to the main channel and below the maximum evident flood discharge. A discharge of 8,700 $\mathrm{ft}^{3} / \mathrm{s}\left(245 \mathrm{~m}^{3} / \mathrm{s}\right.$ ) (fig. 32) occurred May 22, 1973, at the gaging station about $15 \mathrm{mi}(24 \mathrm{~km})$ downstream. Drainage area at the gage is about twice that at the pipeline crossing. 


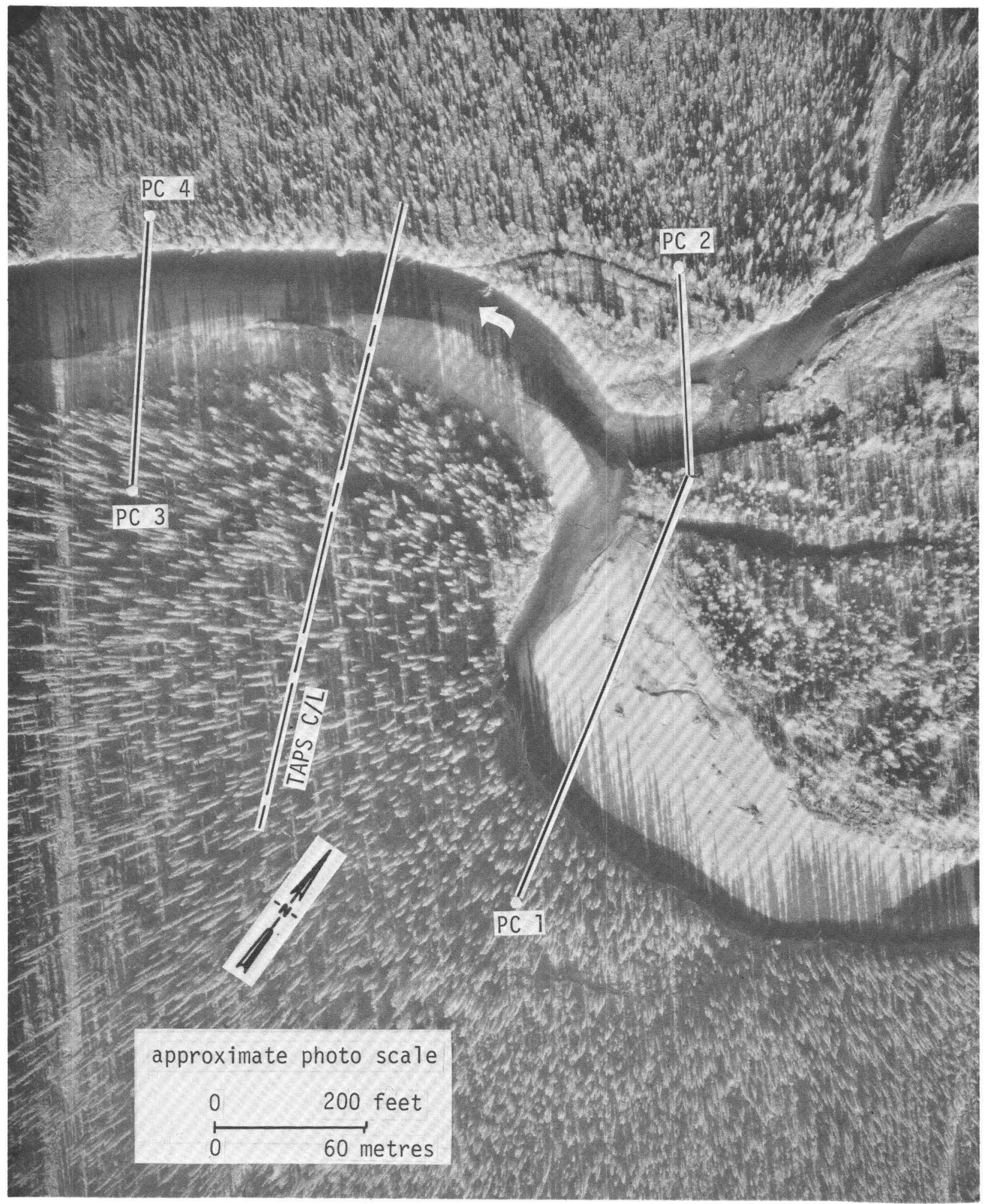

Figure 29. -- Jim River near Prospect Creek Camp, September 28, 1971. WALKER-ALASKA INC. 


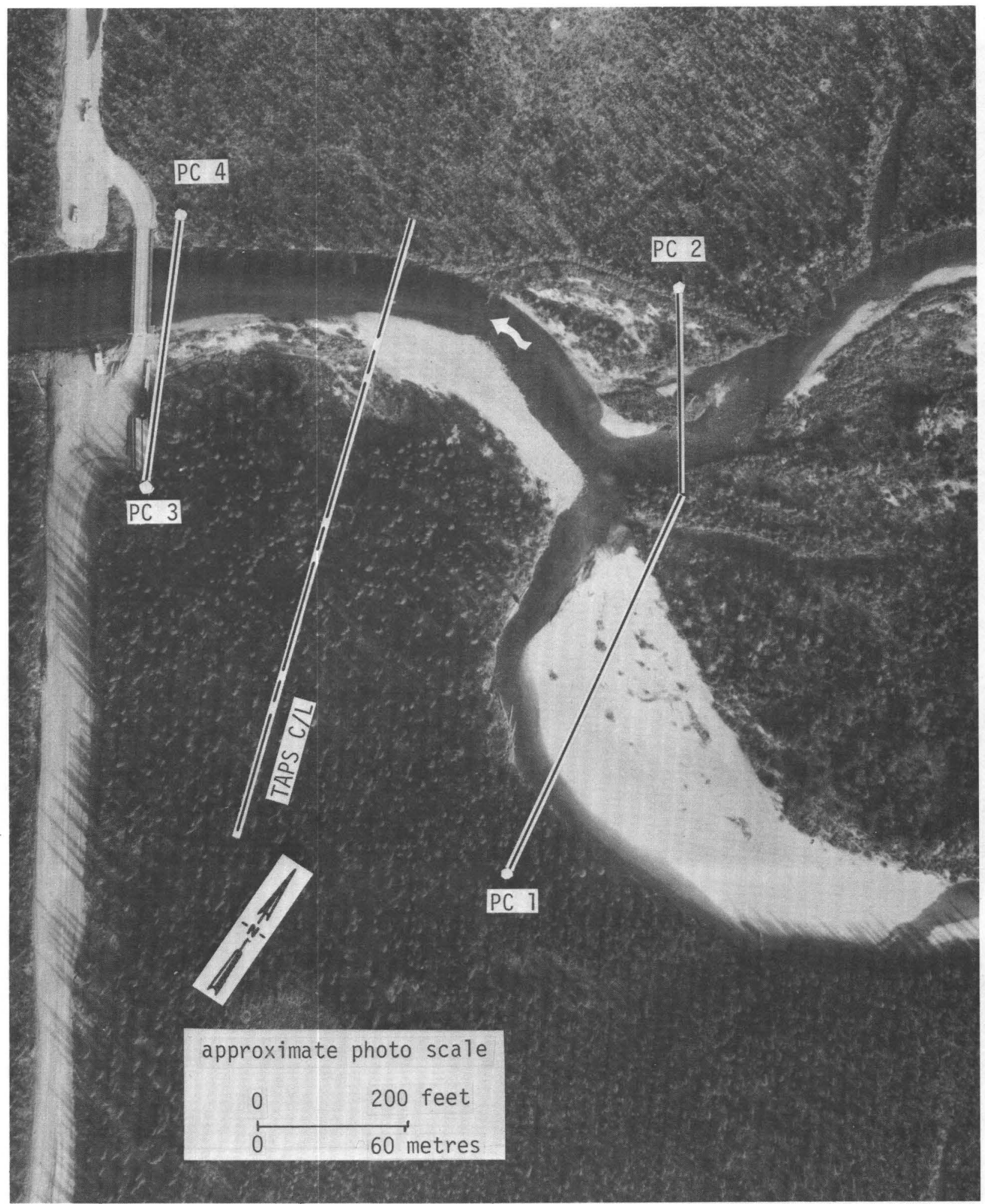

Figure 30. -- Jim River near Prospect Creek Camp, August 25, 1974. AIR PHOTO TECH. 
STATIONING IN METRES

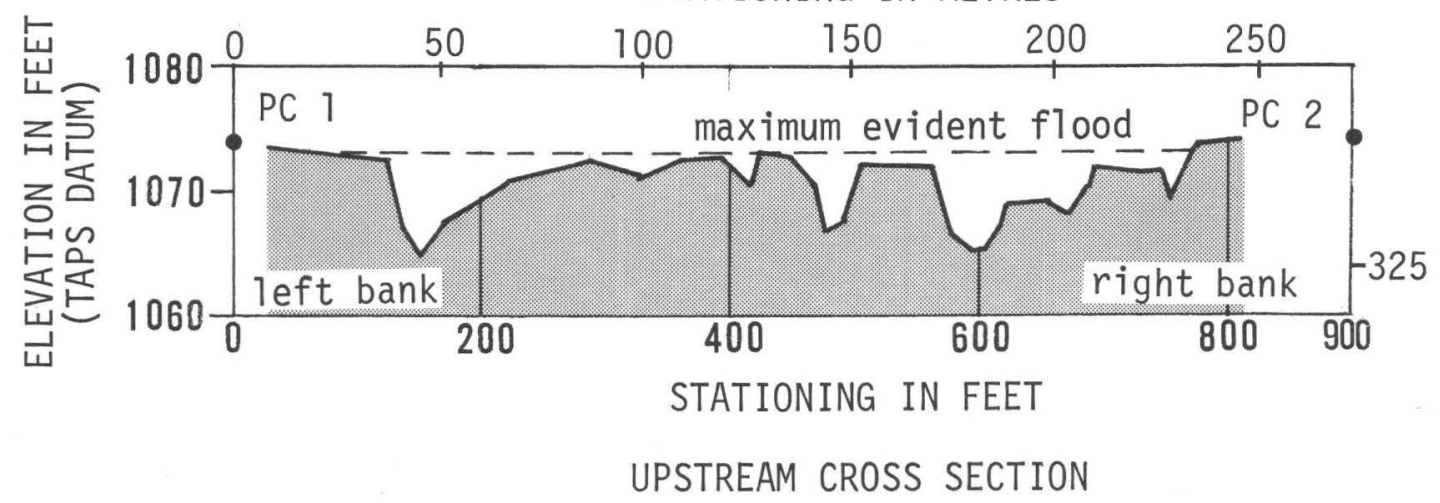

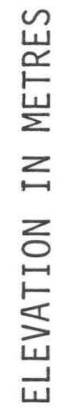

UPSTREAM CROSS SECTION

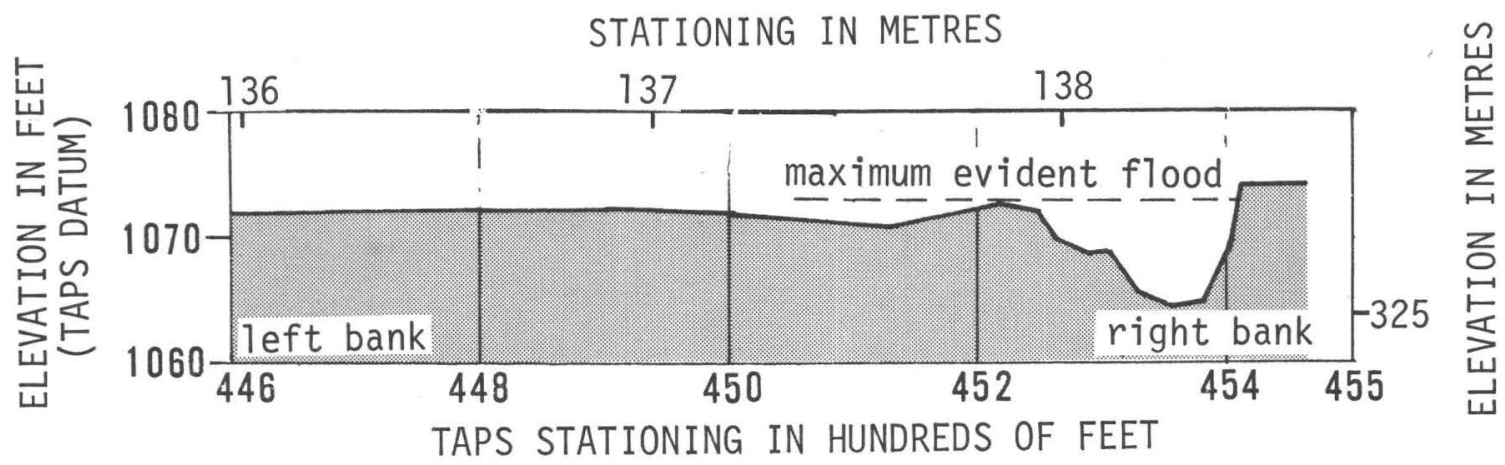

TAPS CENTERLINE CROSS SECTION

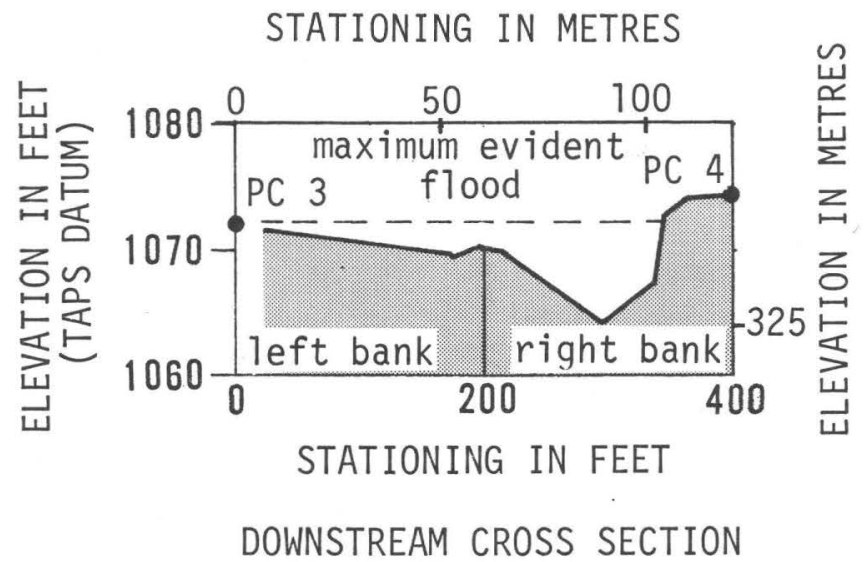

Figure 31.-- Cross sections of Jim River near Prospect Creek Camp, Ju1y 20, 1971. 


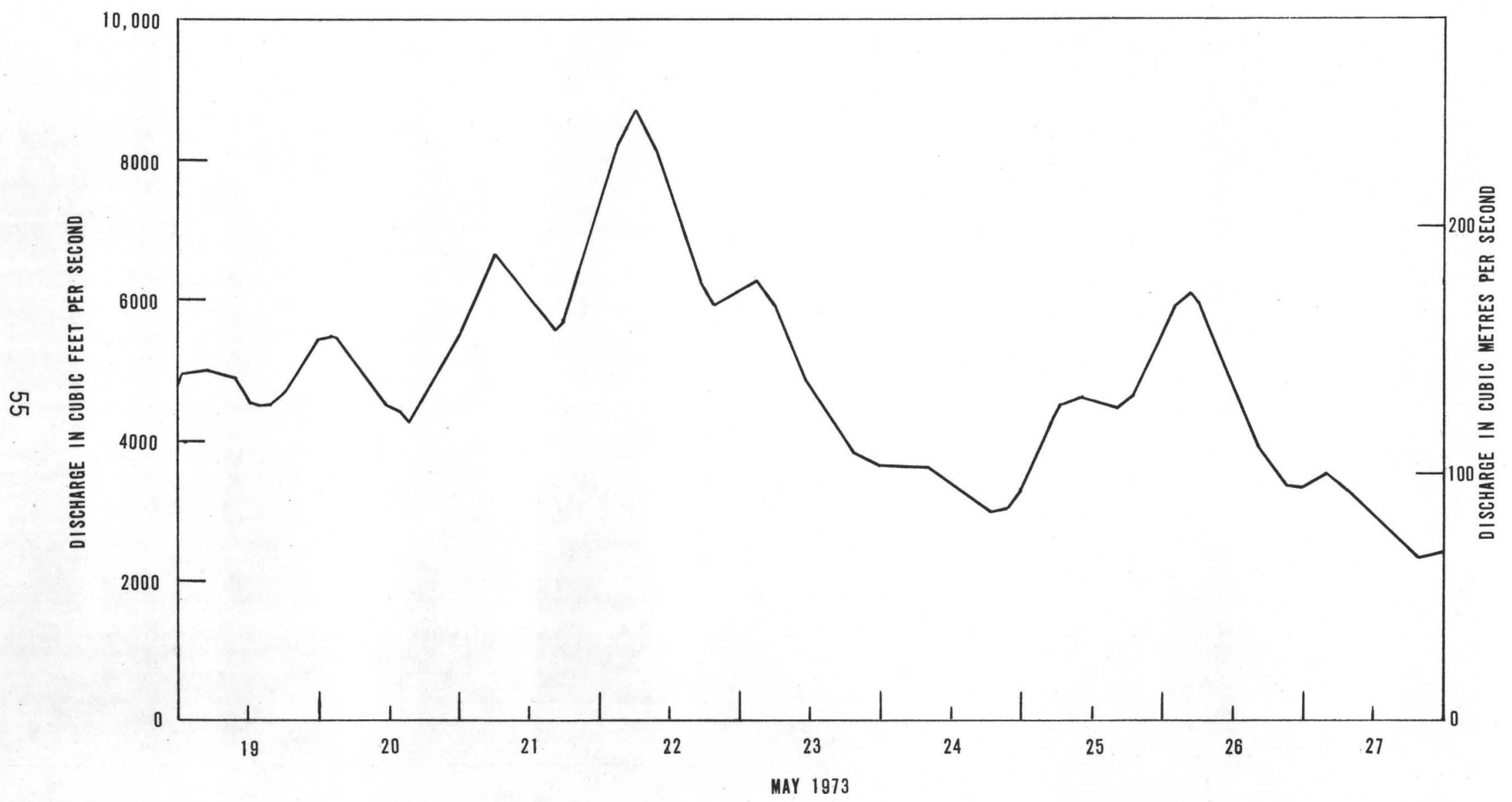

Figure 32. -- Discharge hydrograph at gaging station for Jim River near Prospect Creek Camp. 


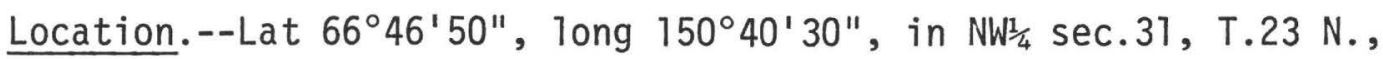
R.14 W., $2 \mathrm{mi}(3 \mathrm{~km})$ upstream from Jim River and approximately $28 \mathrm{mi}(45 \mathrm{~km})$ east of Bettles.

[Bettles (D-2) 1:63,360, U.S. Geological Survey map.]

Channel conditions.--Low-altitude vertical aerial stereophotography (scale 1:2,400) was obtained September 28, 1971, (fig. 33) to document preconstruction topography at the site. Vertical aerial strip photography (scale 1:6,000) taken September 1, 1974, (figs. 34 and 35 ) shows a large gravel-removal site, roadway fill, and bridge about $500 \mathrm{ft}(150 \mathrm{~m})$ downstream of the TAPS centerline. The photographs show no significant lateral erosion. Three cross sections (fig. 36) were surveyed Ju1y 21, 1971, to define preconstruction ground profiles in the crossing reach. In September 1974 a channel survey of the preconstruction cross sections showed no significant erosion.

Floods.--No significant overbank flooding occurred during the period July 21, 1971, through September 1, 1974. 


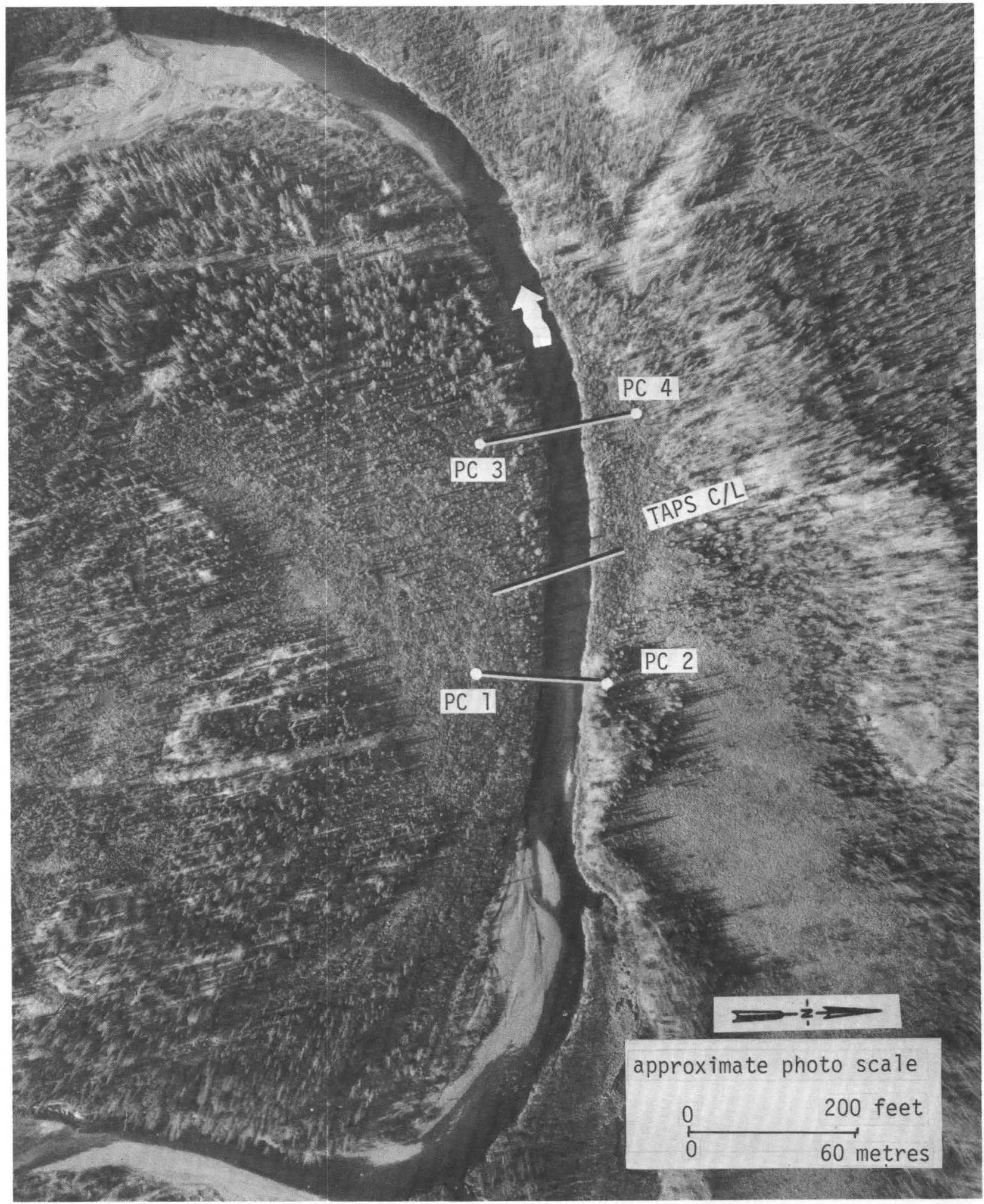

Figure 33. -- Prospect Creek near Prospect Creek Camp, September 28, 1971. WALKER-ALASKA INC. 


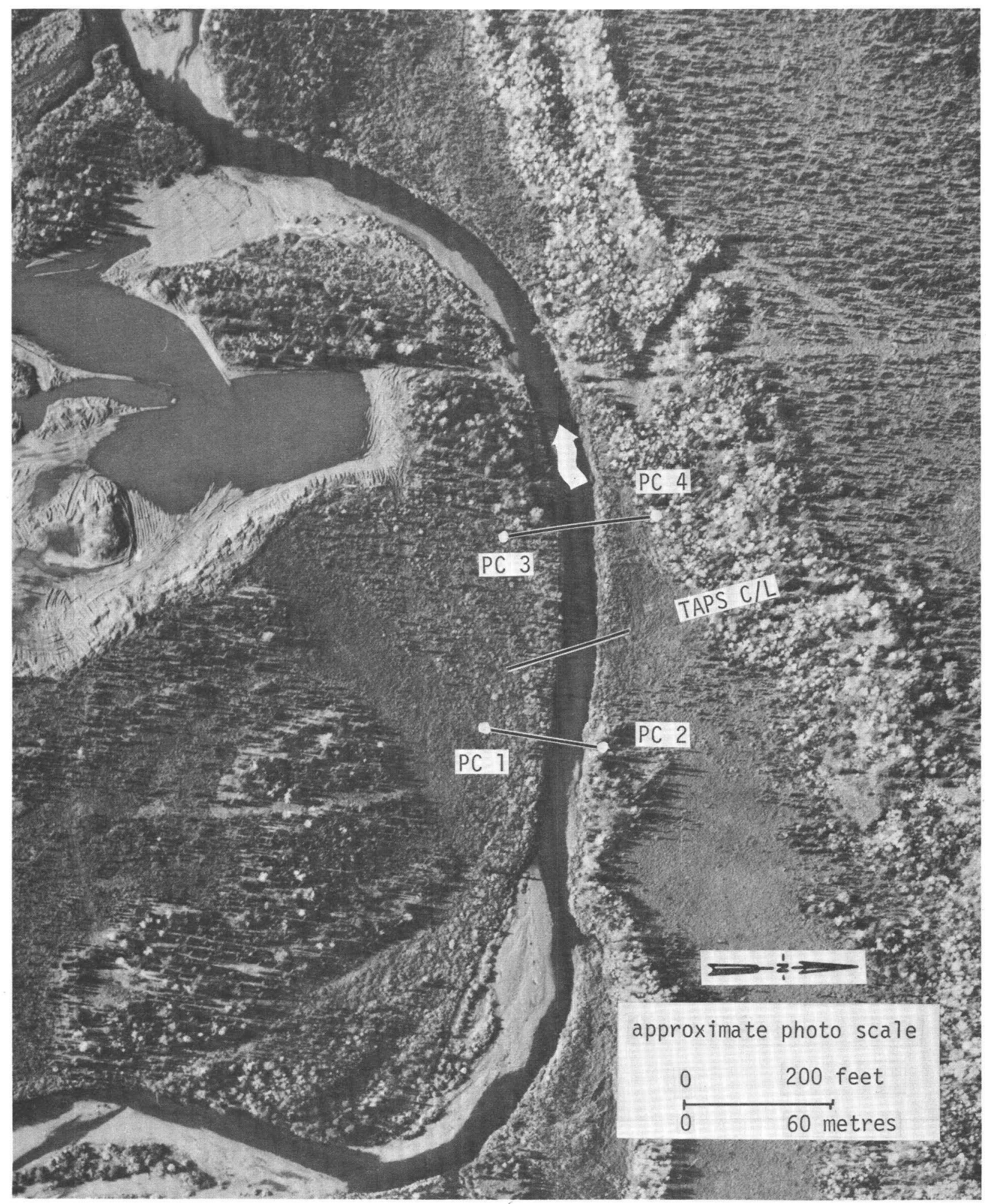

Figure 34. -- Prospect Creek near Prospect Creek Camp, September 1, 1974. ALYESKA PIPELINE SERVICE CO.-AIR PHOTO TECH. 


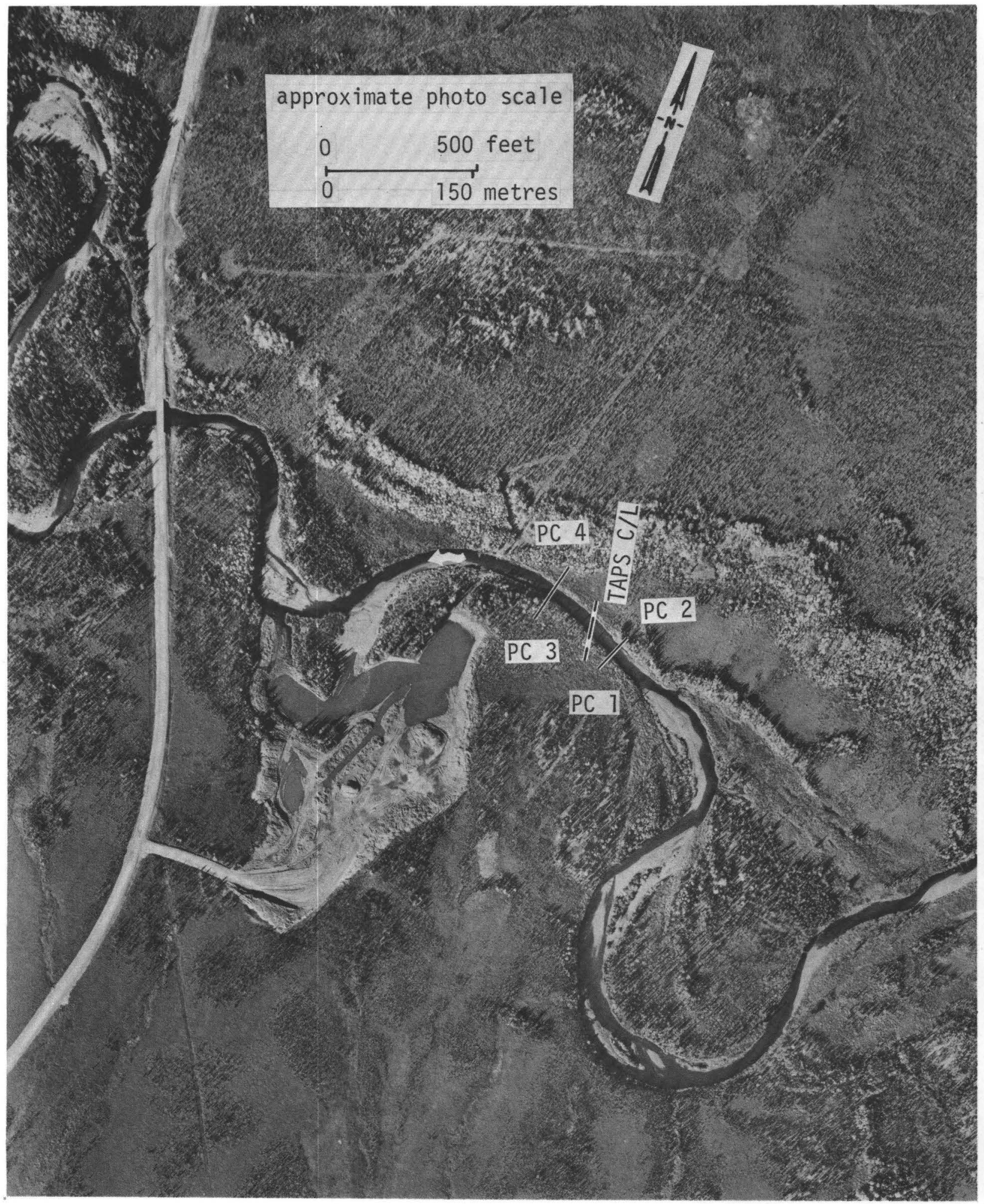

Figure 35. -- Prospect Creek near Prospect Creek Camp, September 1, 1974. ALYESKA PIPELINE SERVICE CO.-AIR PHOTO TECH. 

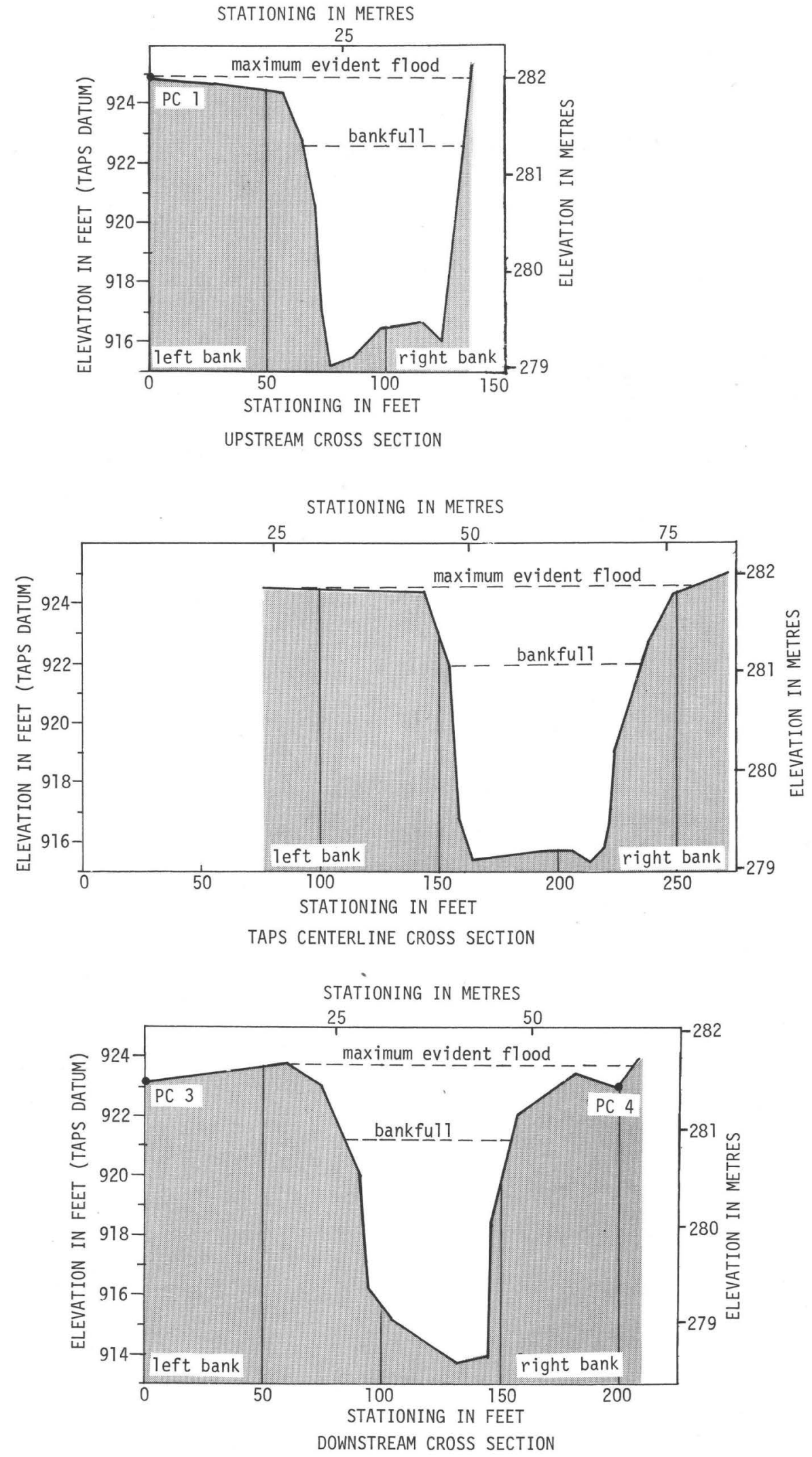

Figure 36.-- Cross sections of Prospect Creek near Prospect Creek Camp, July 21, 1971. 
Location.--Lat $66^{\circ} 26^{\prime} 30^{\prime \prime}$, long $150^{\circ} 37^{\prime} 30^{\prime \prime}$, in SE $\frac{1}{4}$ sec. 30, T.19 N., R.14 W., $5 \mathrm{mi}(8 \mathrm{~km})$ northeast of Caribou Mountain, and approximately $44 \mathrm{mi}(71 \mathrm{~km})$ south-southeast of Bettles. [Bettles (B-2) 1:63,360, U.S. Geological Survey map.]

Channel conditions.--Low-altitude vertical aerial stereophotography (scale 1:2,400) was obtained September 28, 1971, (fig. 37) to document preconstruction topography at the site. Vertical aerial stereophotography (scale 1:6,000) taken August 6, 1974, (fig. 38) shows a roadway and bridge constructed $300 \mathrm{ft}(91 \mathrm{~m})$ above the TAPS centerline. There was no significant erosion in the crossing reach. Three cross sections (fig. 39) were surveyed July 22, 1971, to define preconstruction ground profiles in the crossing reach. In September 1974 a channel survey of the preconstruction cross sections showed no significant erosion.

Floods.--No significant overbank flooding occurred during the period July 22, 1971, through September 1974. 


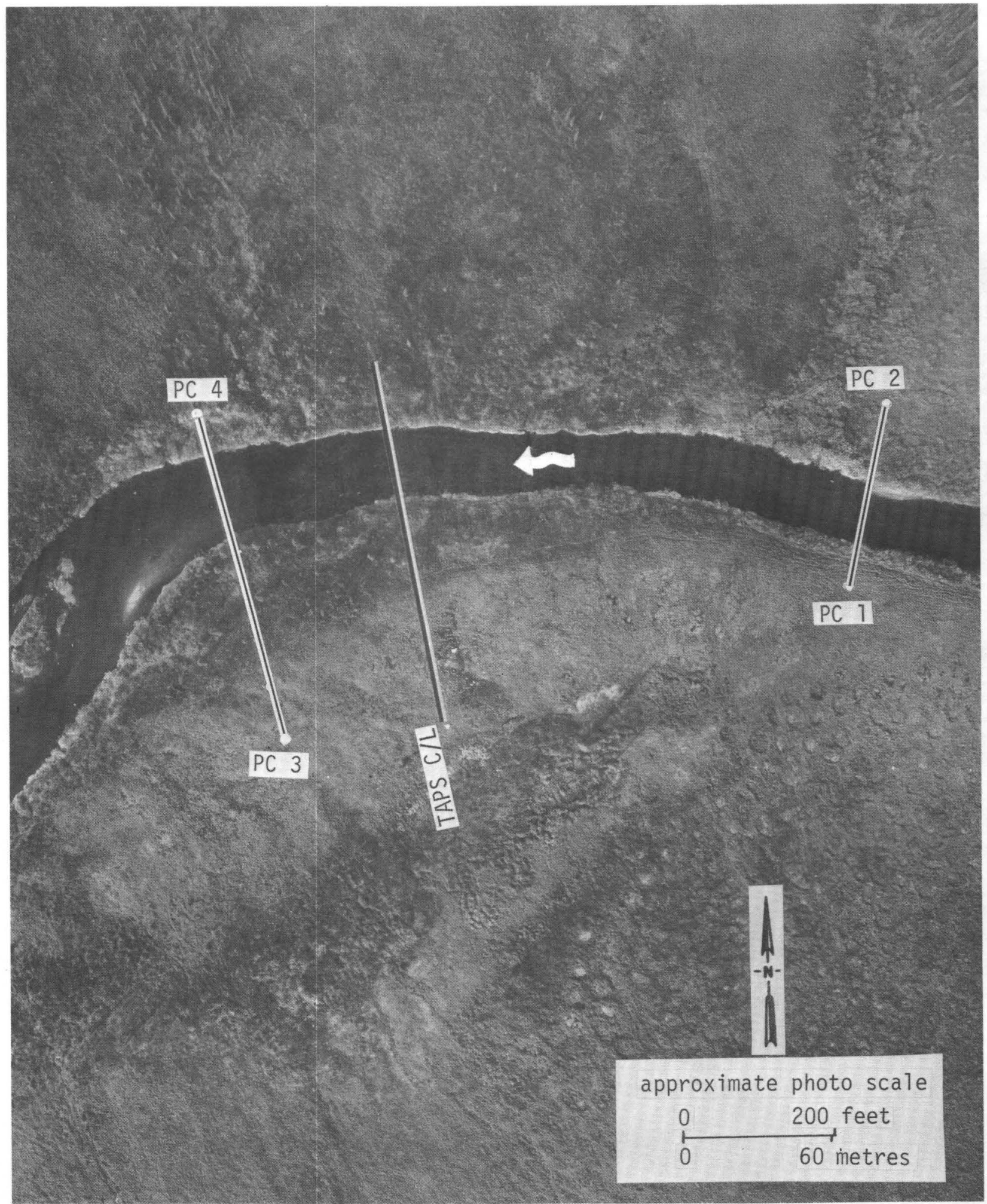

Figure 37. -- Kanuti River near Bettles, September 28, 1971. WALKER-ALASKA INC. 


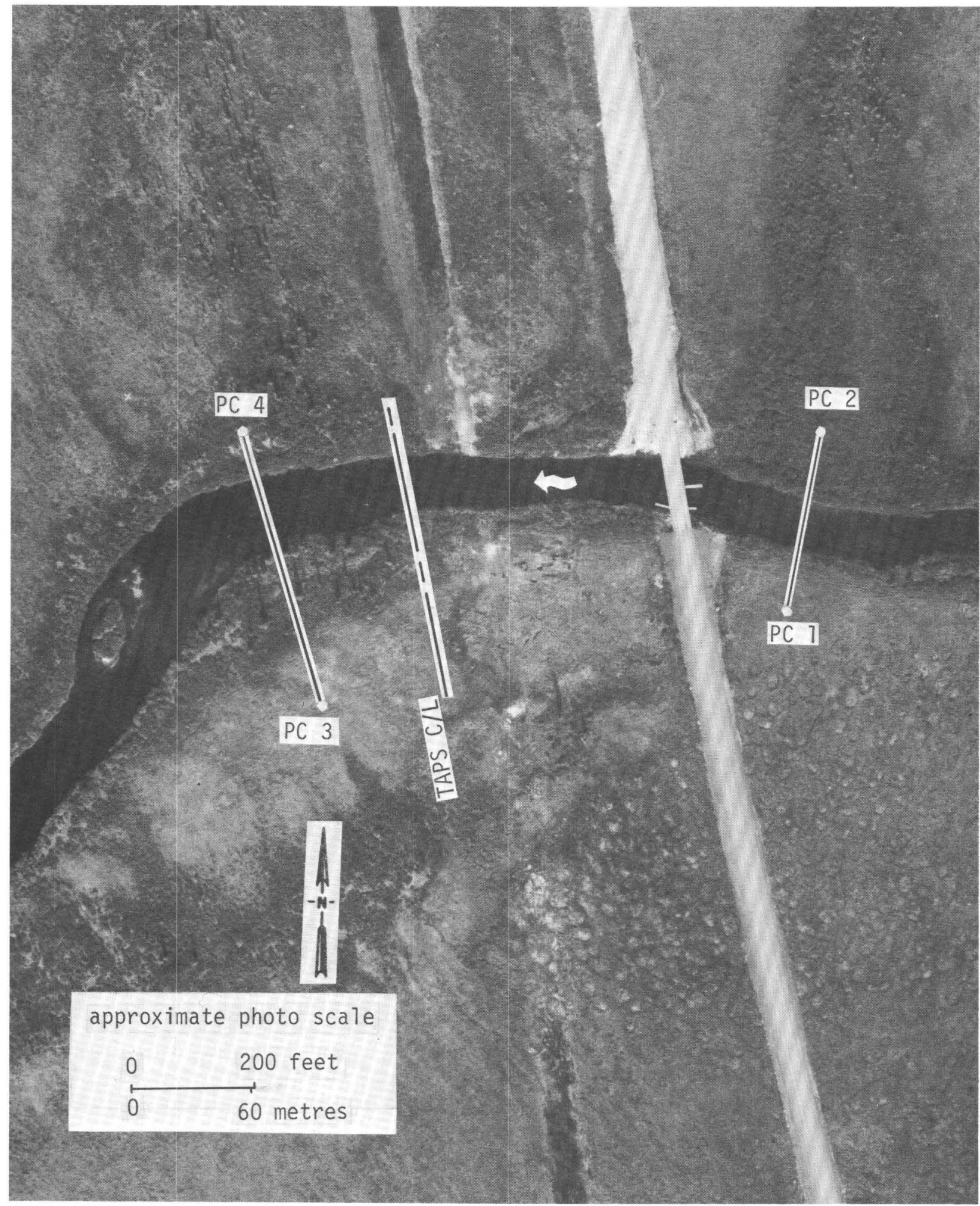

Figure 38. -- Kanuti River near Bettles, August 6, 1974. AIR PHOTO TECH. 

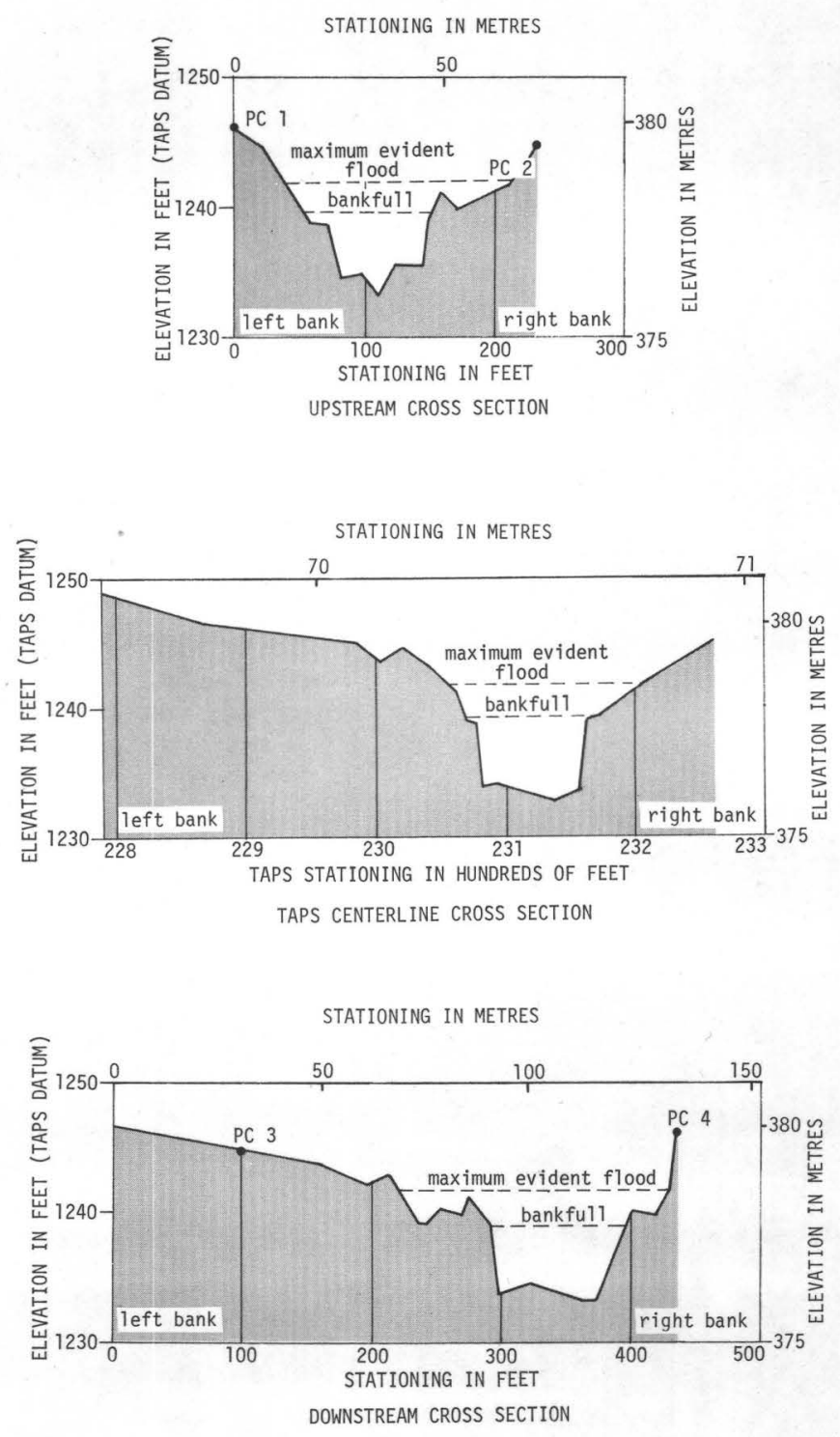

Figure 39. -- Cross sections of Kanuti River near Bettles, Ju1y 22, 1971. 
Location.--Lat $65^{\circ} 40^{\prime} 30^{\prime \prime}$, long $149^{\circ} 04^{\prime} 00^{\prime \prime}$, in SW/ $\frac{1}{4}$ sec. 20 , T.10 N., R.7 W., at Fish Creek and $19 \mathrm{mi}(31 \mathrm{~km})$ northwest of Livengood. [Livengood (C-5) 1:63,360, U.S. Geological Survey map.]

Channel conditions.--Low-altitude vertical aerial stereophotography (scale 1:2,400) was obtained September 28, 1971, (fig. 40) to document preconstruction topography at the site. Vertical aerial strip photography (scale 1:6,000) taken September 1, 1974, (fig. 41) shows no significant channel erosion or construction activities have occurred in the proposed crossing reach since August 3, 1971. Three cross sections (fig. 42) were surveyed August 3, 1971, to define preconstruction ground profiles in the crossing reach. In September 1974 a channel survey of the three cross sections found $5 \mathrm{ft}(2 \mathrm{~m})$ of lateral bank erosion in the upstream section. Floods.--No significant floods occurred during the period of the erosion investigation August 3, 1971, through September 1, 1974. The maximum observed discharge for the period, 5,260 $\mathrm{ft}^{3} / \mathrm{s}$ (149 $\mathrm{m}^{3} / \mathrm{s}$ ) (fig. 43), was confined to the main channel far below the maximum evident flood. 


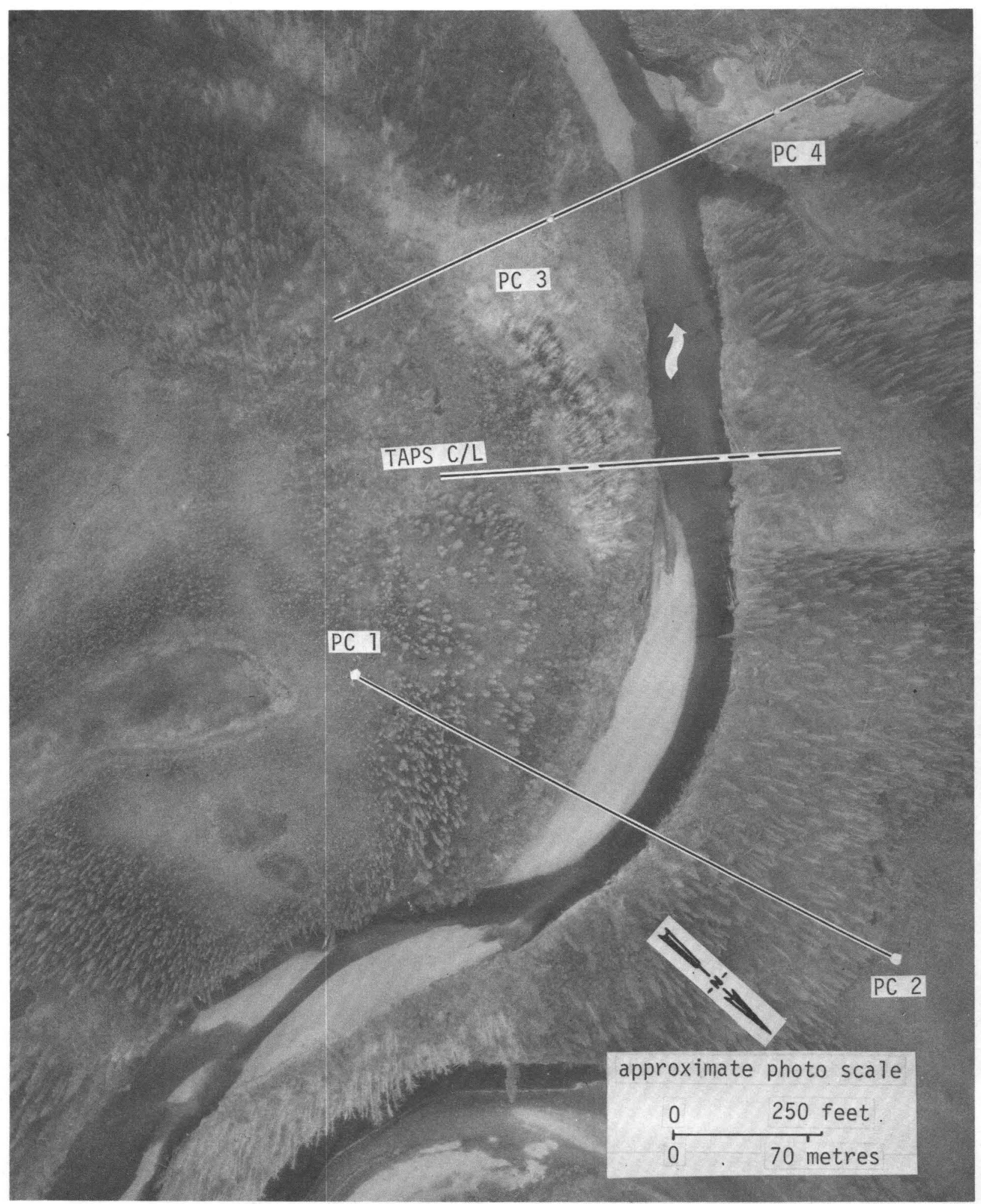

Figure 40. -- Hess Creek near Livengood, September 28, 1971. WALKER-ALASKA INC. 


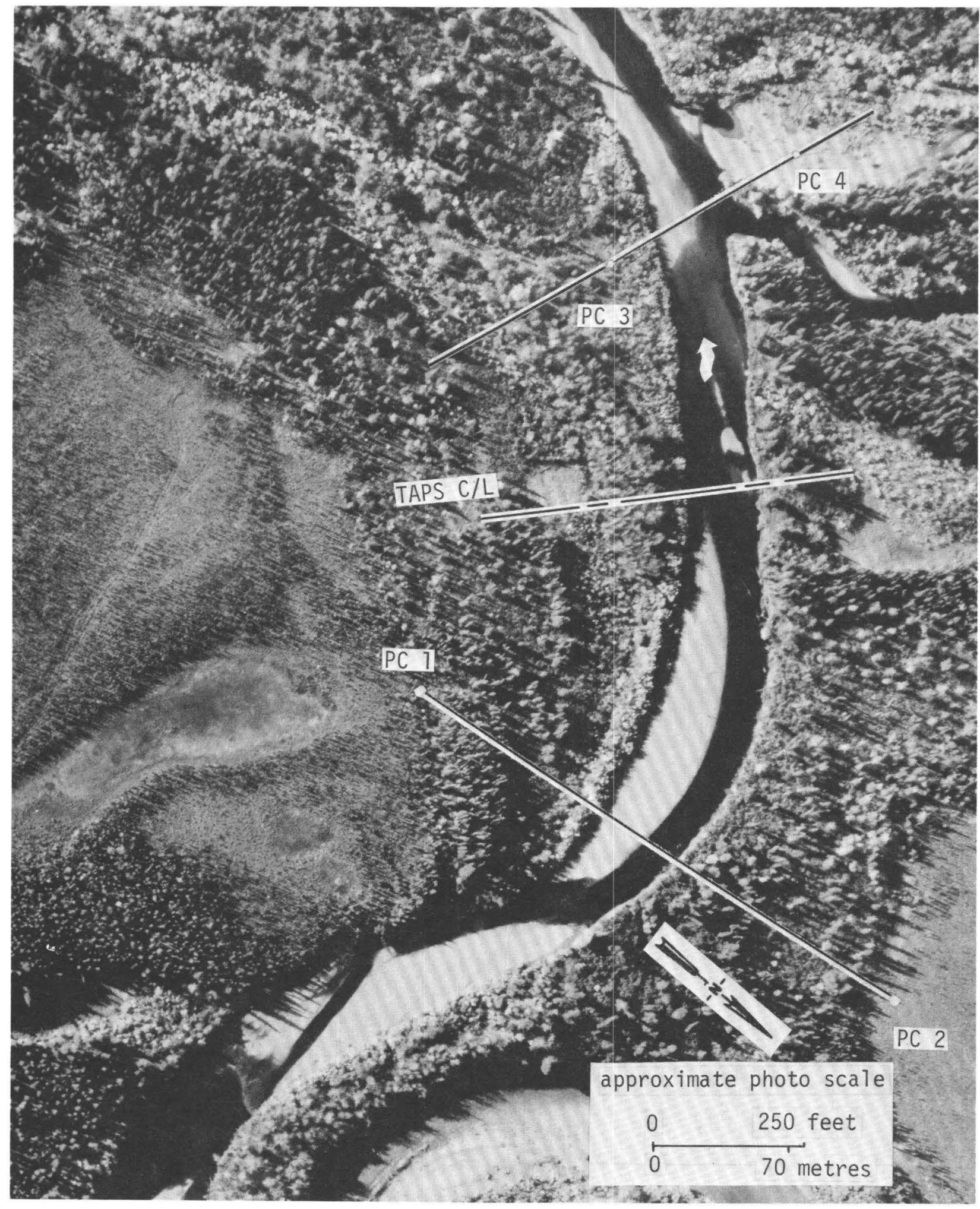

Figure 41. -- Hess Creek near Livengood, September 1, 1974. ALYESKA PIPELINE SERVICE CO.-AIR PHOTO TECH. 
STATIONING IN METRES
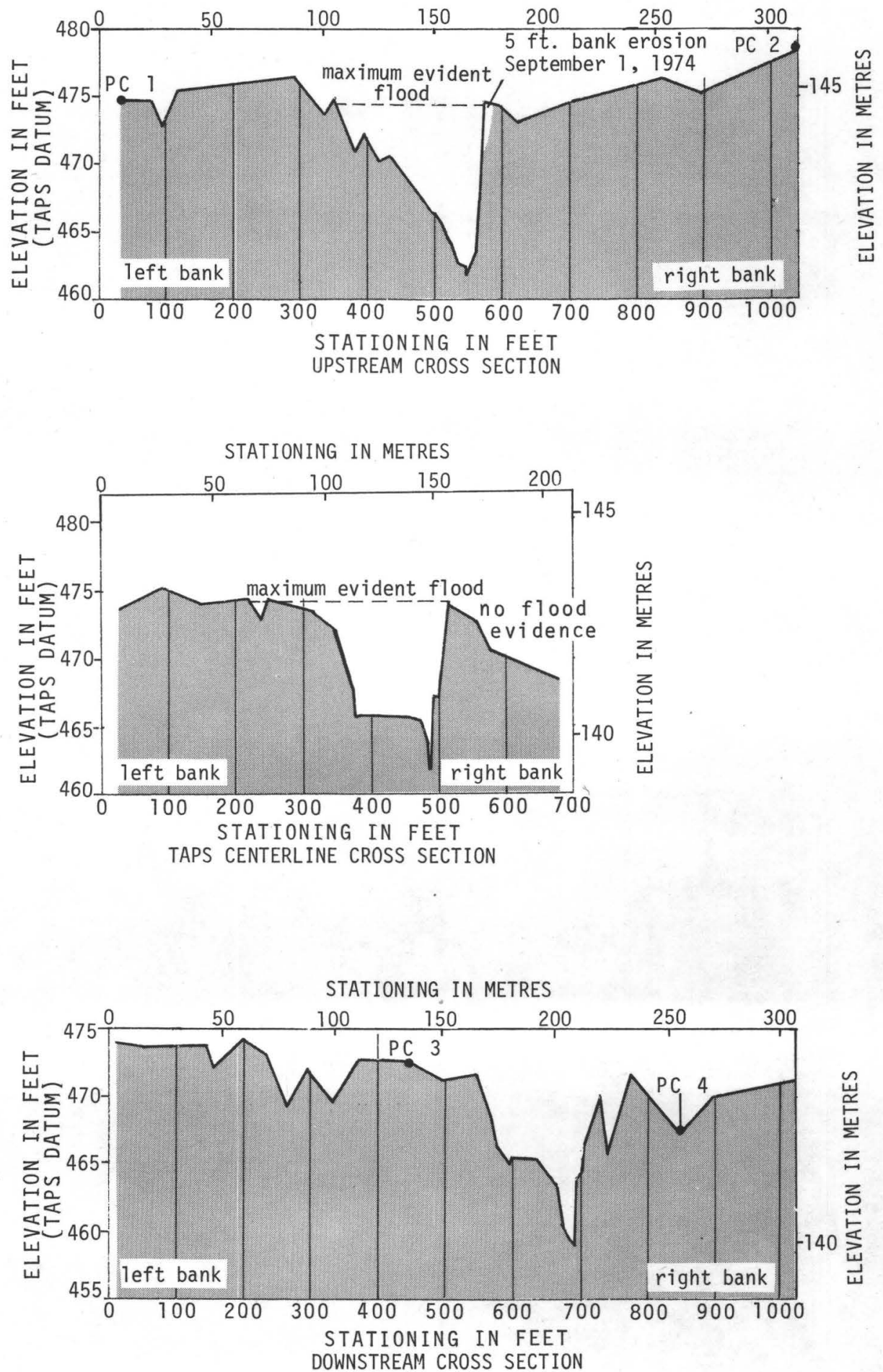

Figure 42. -- Cross sections of Hess Creek near Livengood, August 3, 1971. 


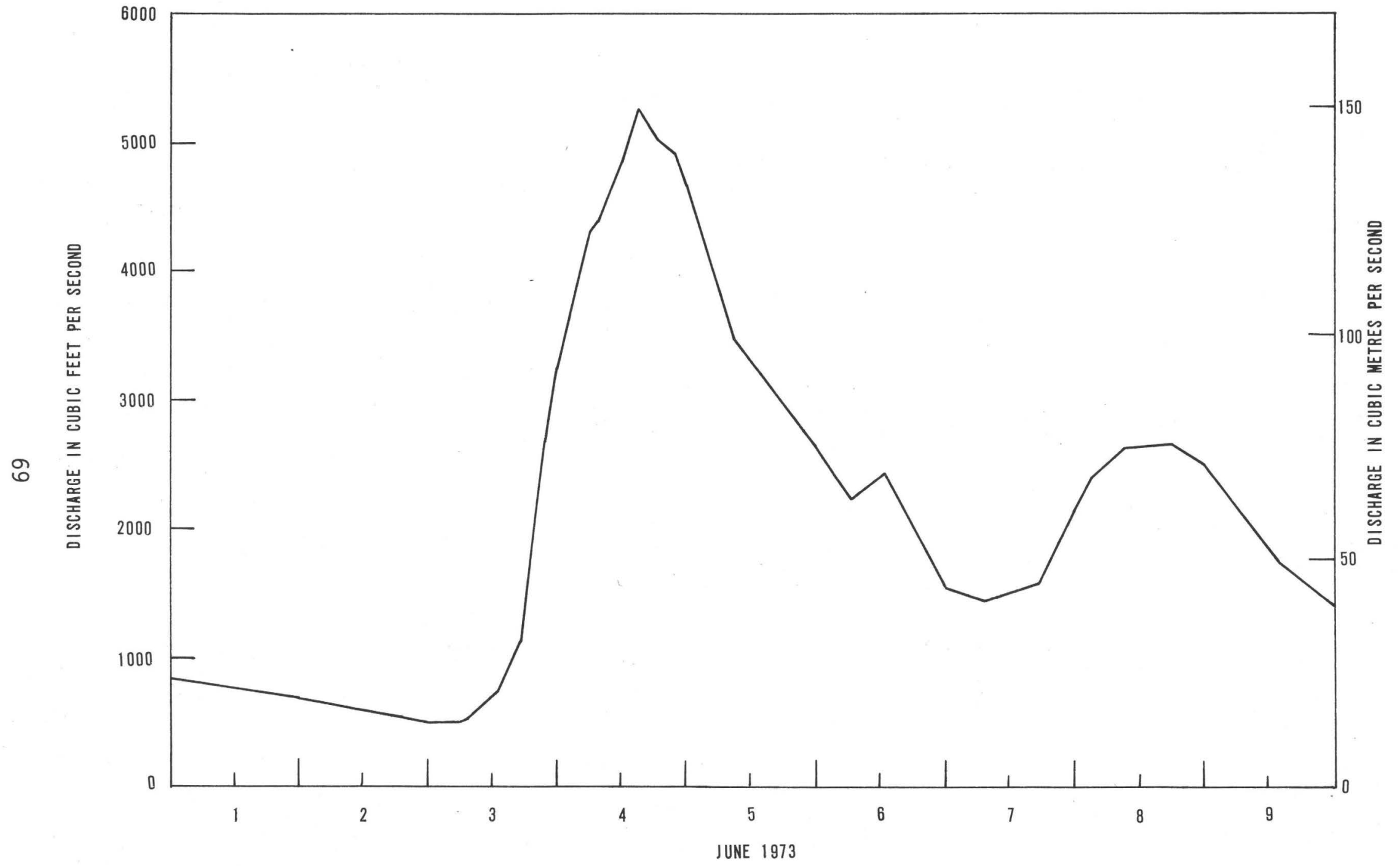

Figure 43.-- Discharge hydrograph for Hess Creek near Livengood. 


\section{Chatanika River near 01nes}

Location.--Lat $65^{\circ} 03^{\prime} 41^{\prime \prime}$, long $147^{\circ} 48^{\prime} 39^{\prime \prime}$, in $\mathrm{NW}^{1} / 4$, sec. 29 , T.3 N., R. 1 W., approximately $4.5 \mathrm{mi}(7.2 \mathrm{~km})$ west of $01 \mathrm{nes}$ and $15 \mathrm{mi}$ $(24 \mathrm{~km})$ north of Fairbanks.

[Livengood (A-2) 1:63,360, U.S. Geological Survey map.]

Channel conditions.--High-altitude vertical aerial stereophotography (scale 1:15,840) was obtained August 18, 1969, (fig. 44) to document preconstruction topography at the site. Vertical aerial strip photography (scale 1:6,000) taken September 4, 1974, (fig. 45) shows no significant channel erosion or construction activities have occurred in the proposed crossing reach since August 18, 1969. Three cross sections (fig. 46) were surveyed August 3, 1971, to define preconstruction ground profiles in the crossing reach. In June 1974 a channel survey of measurements from photograph control points found no significant lateral erosion.

Floods.--No significant floods occurred during the period of the erosion investigation August 18, 1969, through September 4, 1974. 


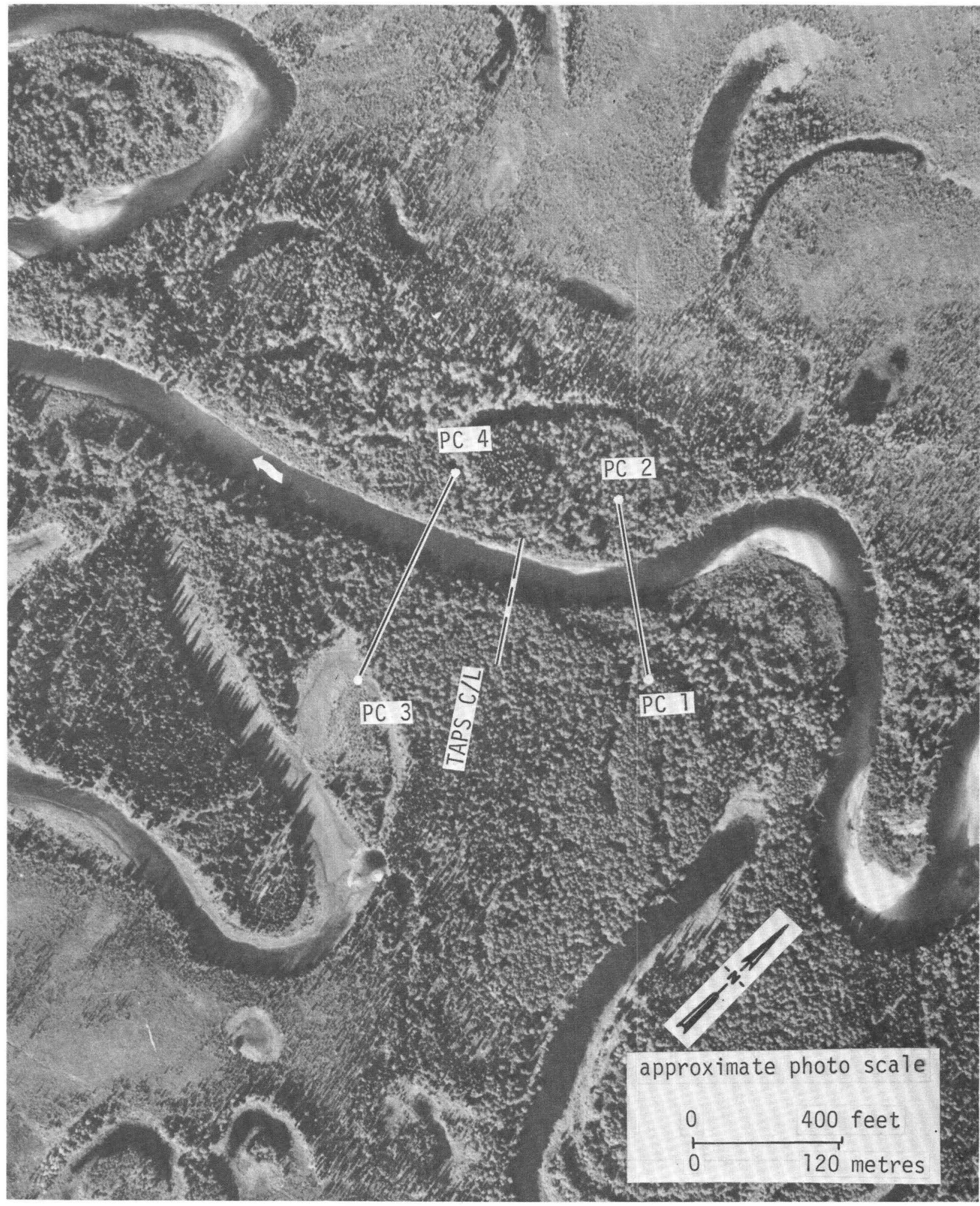

Figure 44. -- Chatanika River near 01nes, August 18, 1969. BUREAU OF LAND MANAGEMENT 


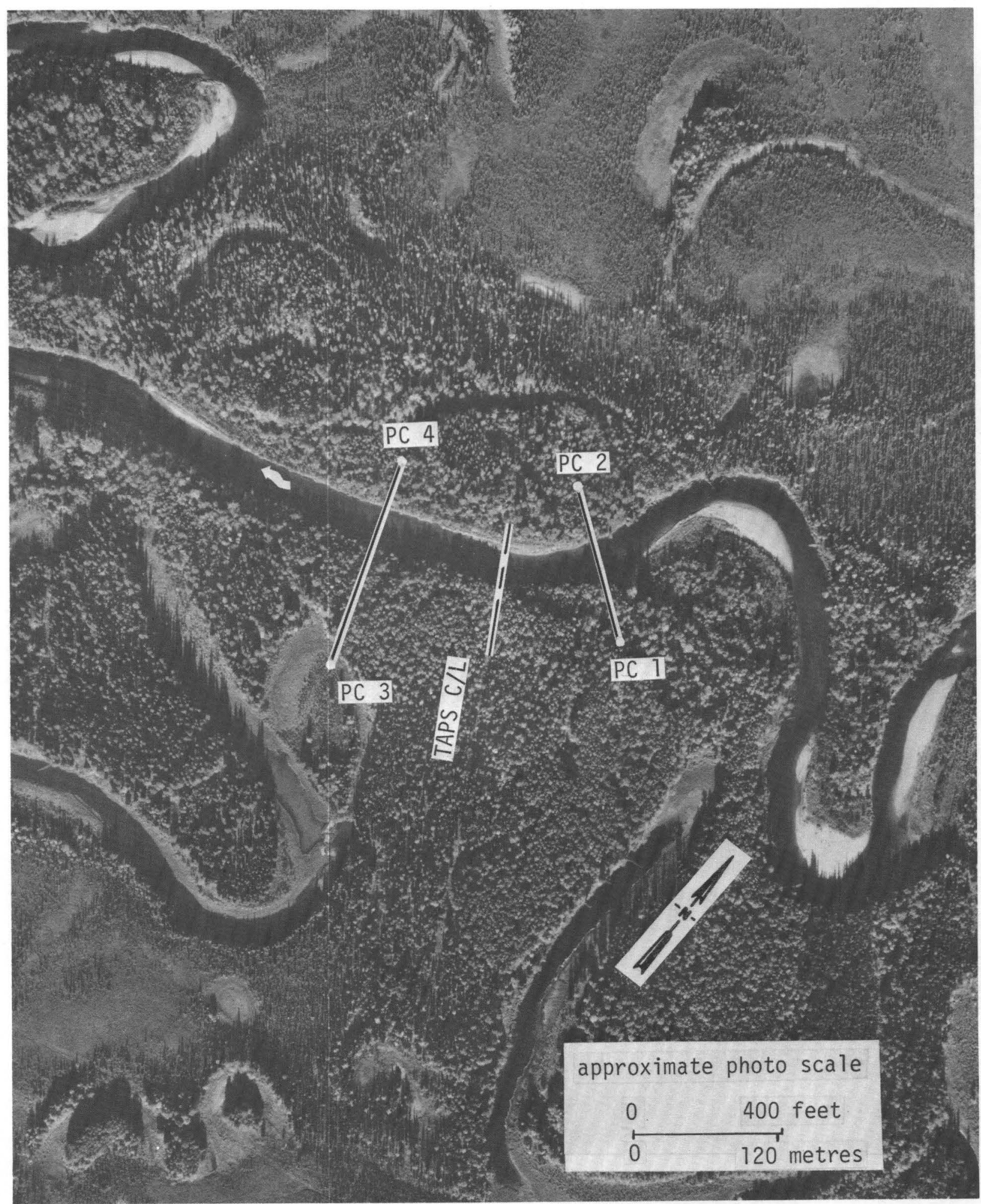

Figure 45. -- Chatanika River near 01nes, September 4, 1974. ALYESKA PIPELINE SERVICE CO.-AIR PHOTO TECH. 
STATIONING IN METRES

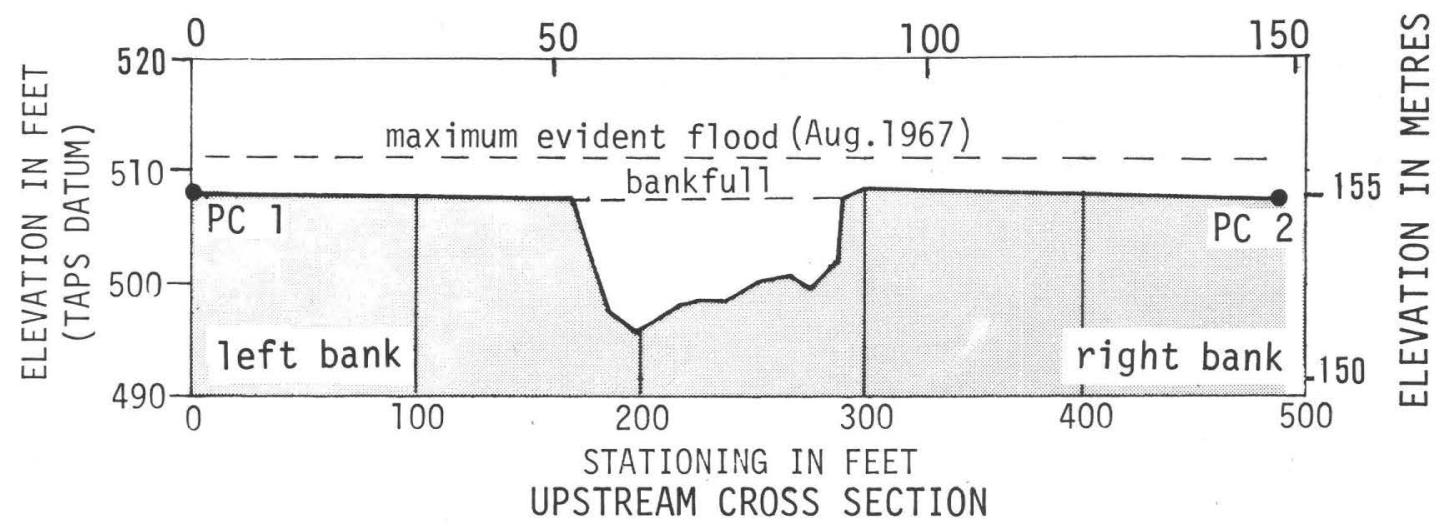

STATIONING IN METRES

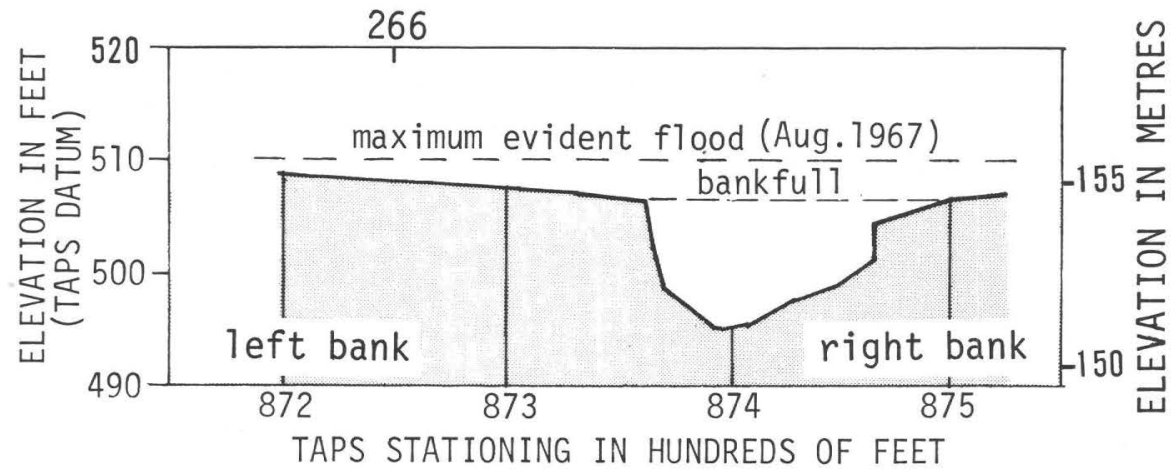

TAPS CENTERLINE CROSS SECTION

STATIONING IN METRES

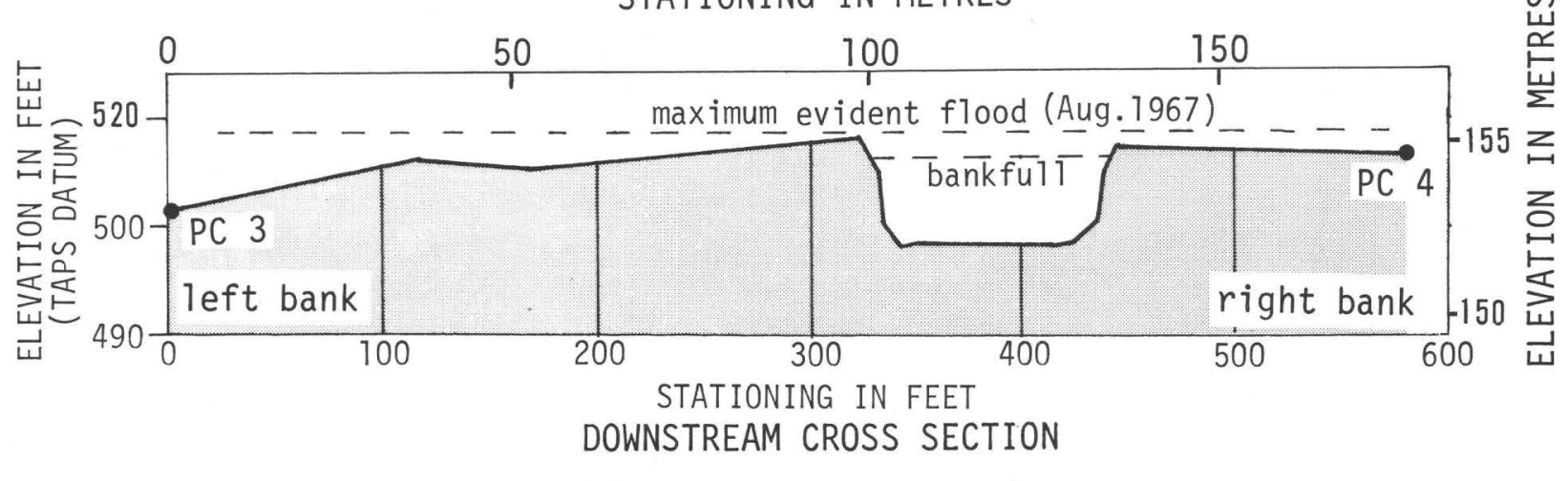

Figure 46.-- Cross sections of Chatanika River near 01nes, August 3, 1971. 


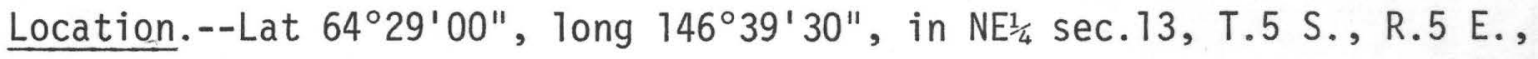
about $8 \mathrm{mi}(13 \mathrm{~km})$ upstream from the Richardson Highway. [Big Delta (B-6) 1:63,360, U.S. Geological Survey map.]

Channel conditions.--High-altitude vertical aerial stereophotography (scale 1:24,000) was obtained August 14, 1969, (fig. 47) to document preconstruction topography at the site. Vertical aerial strip photography (scale 1:6,000) taken August 31, 1974, (fig. 48) shows no significant channel erosion or construction activities have occurred in the proposed crossing reach since August 14, 1969. Three cross sections (fig. 49) were surveyed August 5, 1971, to define preconstruction ground profiles in the crossing reach. On September 16, 1974, a channel survey of the three cross sections found no significant lateral erosion.

Floods.--iNo significant overbank flooding occurred during the period August 1969 through September 16, 1974. The maximum observed discharge for the period, $23,300 \mathrm{ft}^{3} / \mathrm{s}\left(660 \mathrm{~m}^{3} / \mathrm{s}\right)$ (fig. 50 ), was confined to the main channel. 


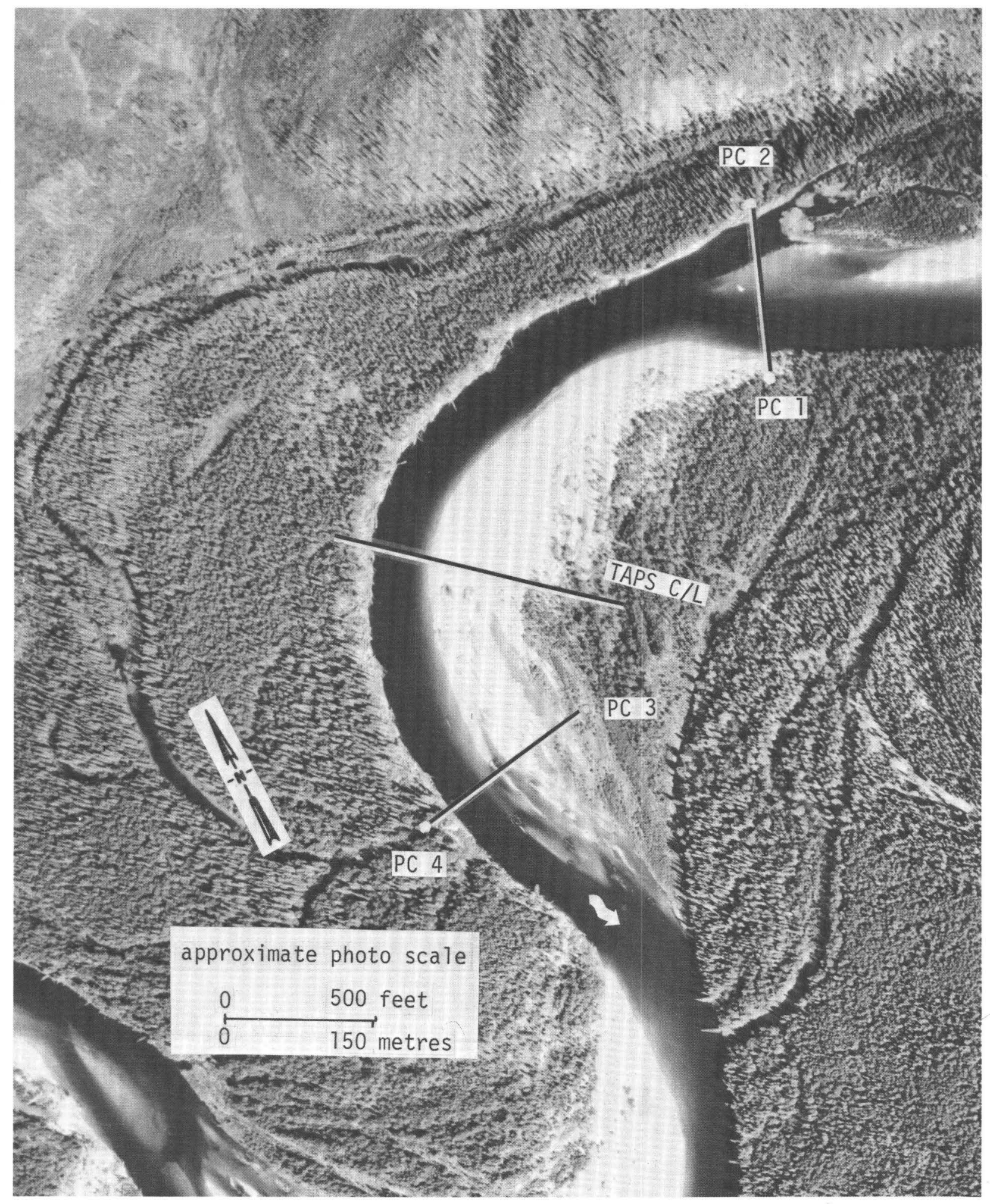

Figure 47. -- Salcha River near Salchaket, August 14, 1969. TOBIN RESEARCH INC. 


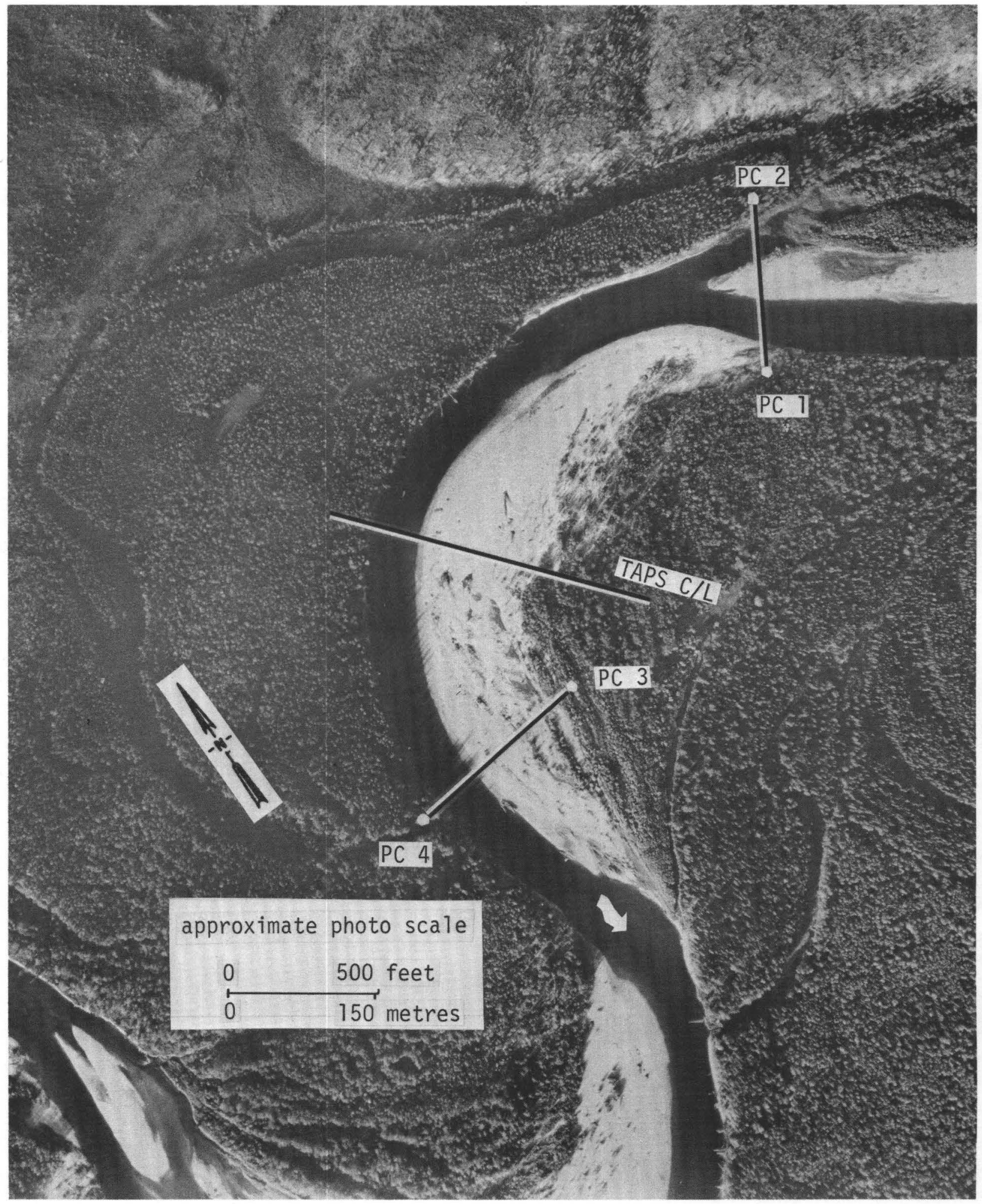

Figure 48. -- Salcha River near Salchaket, August 31, 1974. ALYESKA PIPELINE SERVICE CO.-AIR PHOTO TECH. 
STATIONING IN METRES

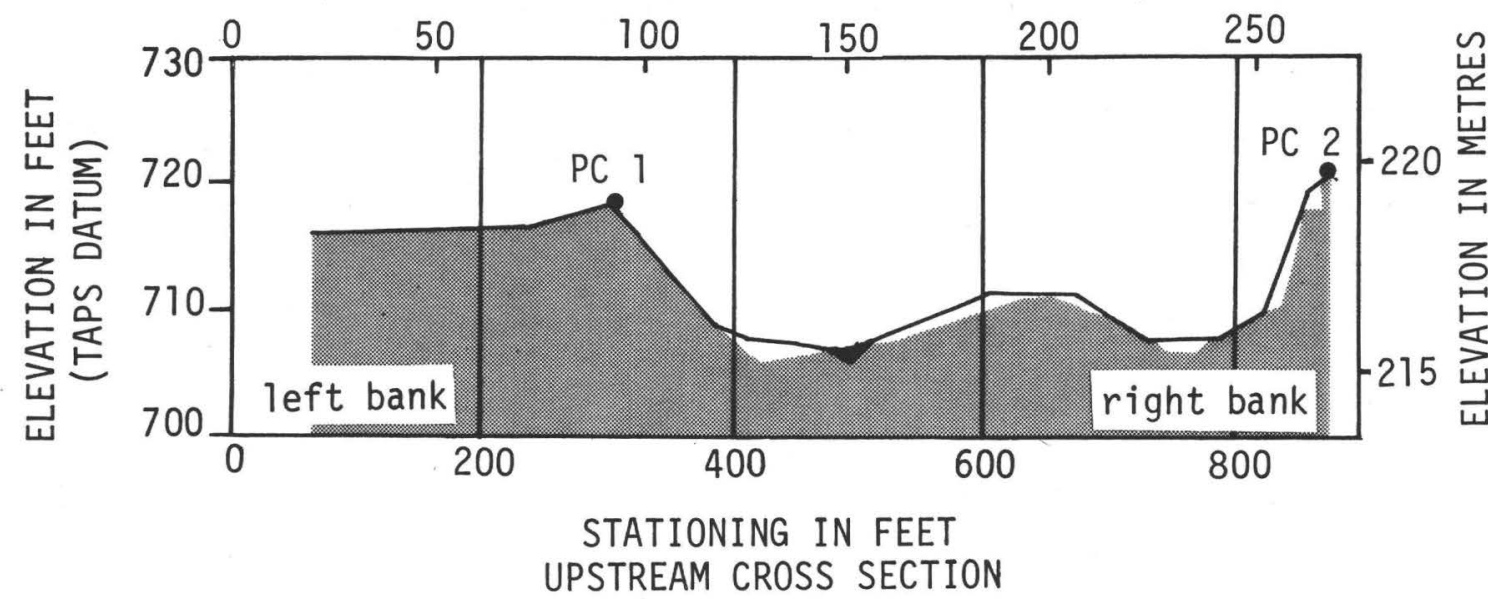

BLACK AREAS INDICATE DEPOSITION, CLEAR AREAS INDICATE EROSION,

SOLID LINE IS ORIGINAL SECTION.

STATIONING IN METRES

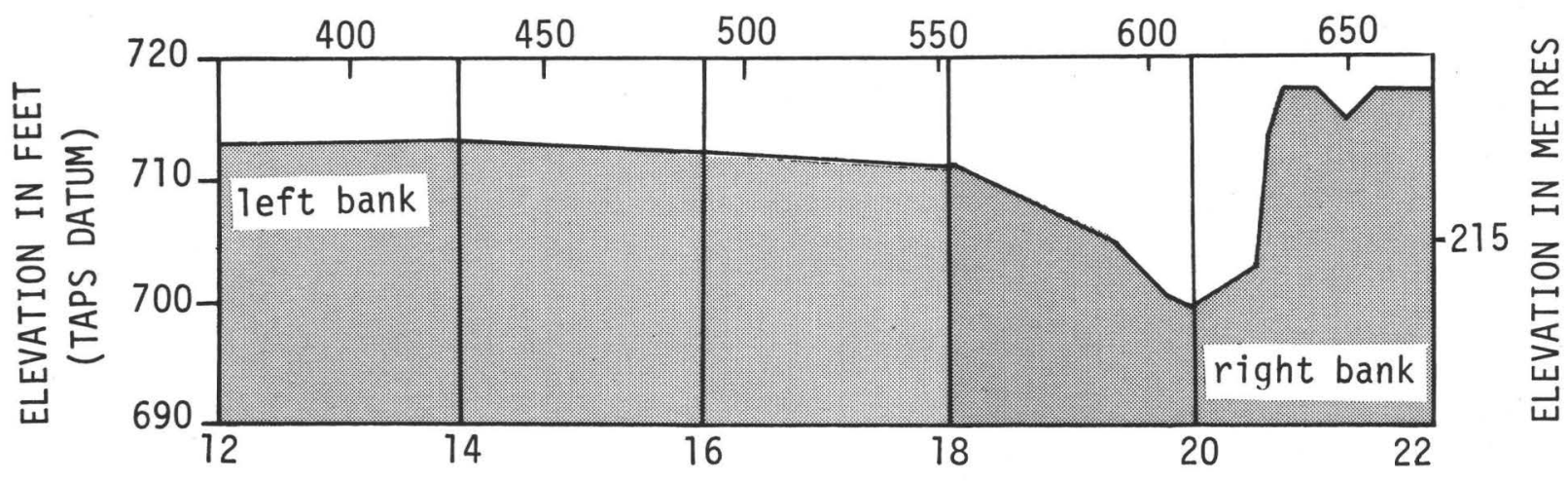

TAPS STATIONING IN HUNDREDS OF FEET

TAPS CENTERLINE CROSS SECTION

STATIONING IN METRES

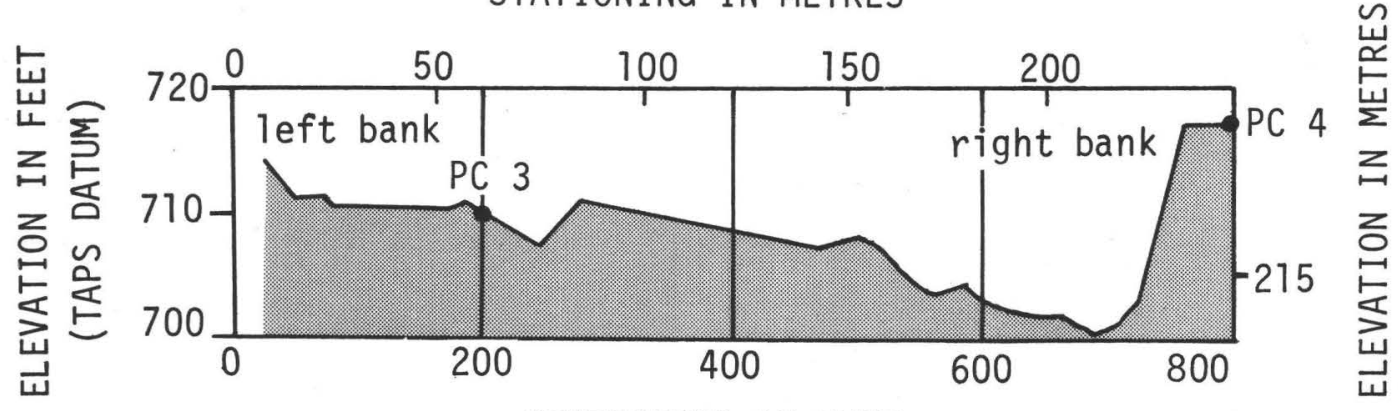

STATIONING IN FEET

DOWNSTREAM CROSS SECTION

Figure 49. -- Cross sections of Salcha River near Salchaket, August 5, 1971 and September 16, 1974. 


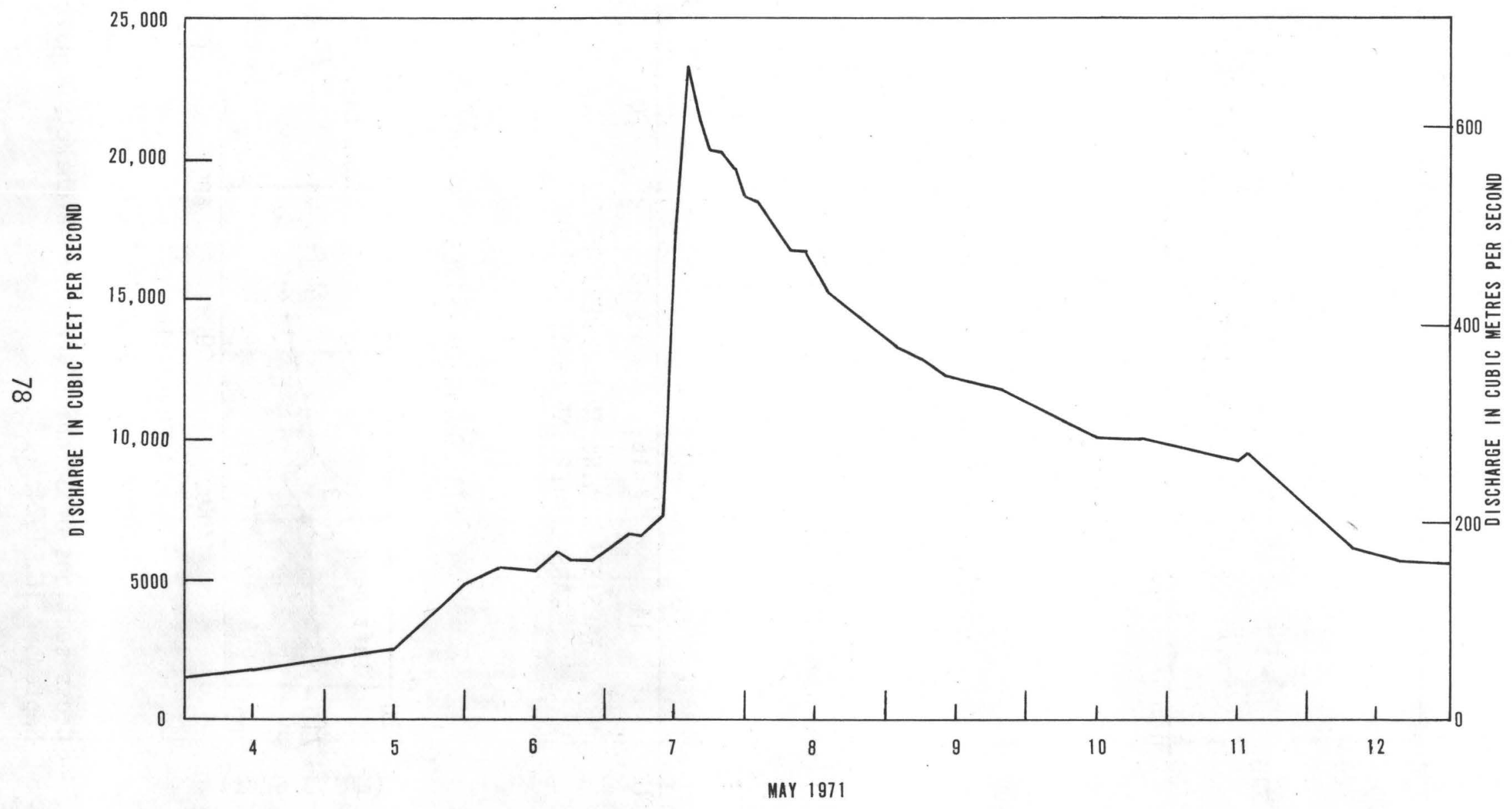

Figure 50.-- Discharge hydrograph for Salcha River near Salchaket. 
Location.--Lat $63^{\circ} 26^{\prime} 42^{\prime \prime}$, long $145^{\circ} 48^{\prime} 06^{\prime \prime}$, in NE $\frac{1}{4} \mathrm{sec} .15, \mathrm{~T} .17 \mathrm{~S}$, , R.10 E., at pipeline crossing, $0.1 \mathrm{mi}(0.2 \mathrm{~km})$ upstream from Delta River, and about $6 \mathrm{mi}(10 \mathrm{~km})$ south of Rapids. [Mt. Hayes (B-4) 1;63,360, U.S. Geological Survey map.]

Channel conditions.--Low-altitude vertical aerial stereophotography (scale 1:2,400) was obtained September 23, 1972, (fig. 51) to document preconstruction topography at the site. Vertical aerial strip photography (scale 1:6,000) taken August 31, 1974, (fig. 52) shows no significant channel erosion or construction activities have occurred in the crossing reach since September 23, 1972. Three cross sections (fig. 53) were surveyed in September 1972 to define preconstruction ground profiles in the crossing reach. In September 1974 a channel survey of the three cross sections found no significant lateral erosion.

Floods.--No significant flooding occurred during the period of the erosion investigation September 23, 1972, through September 1974. 


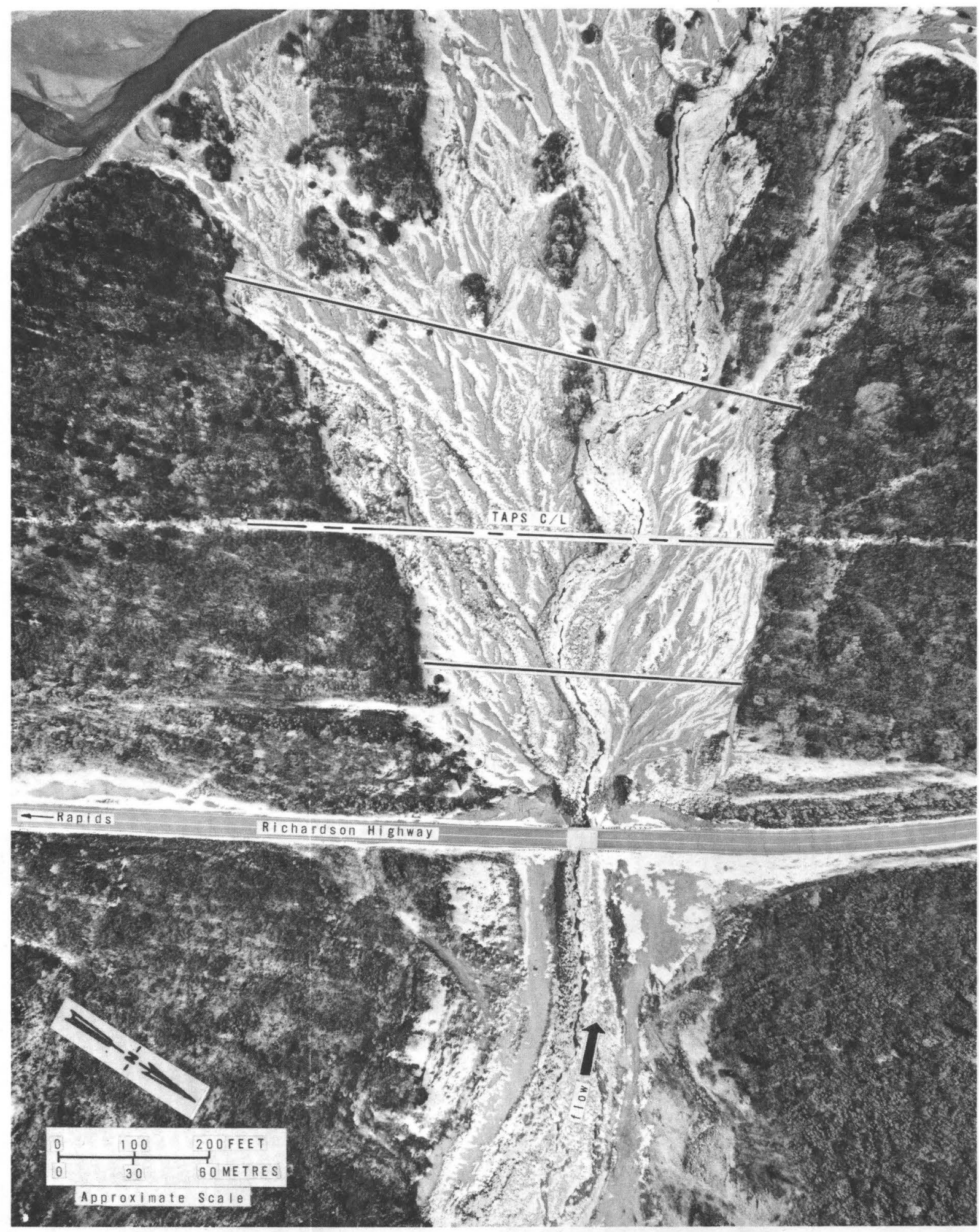

Figure 51. -- Flood Creek near Rapids, September 23, 1972. NORTH PACIFIC AERIAL SURVEYS 


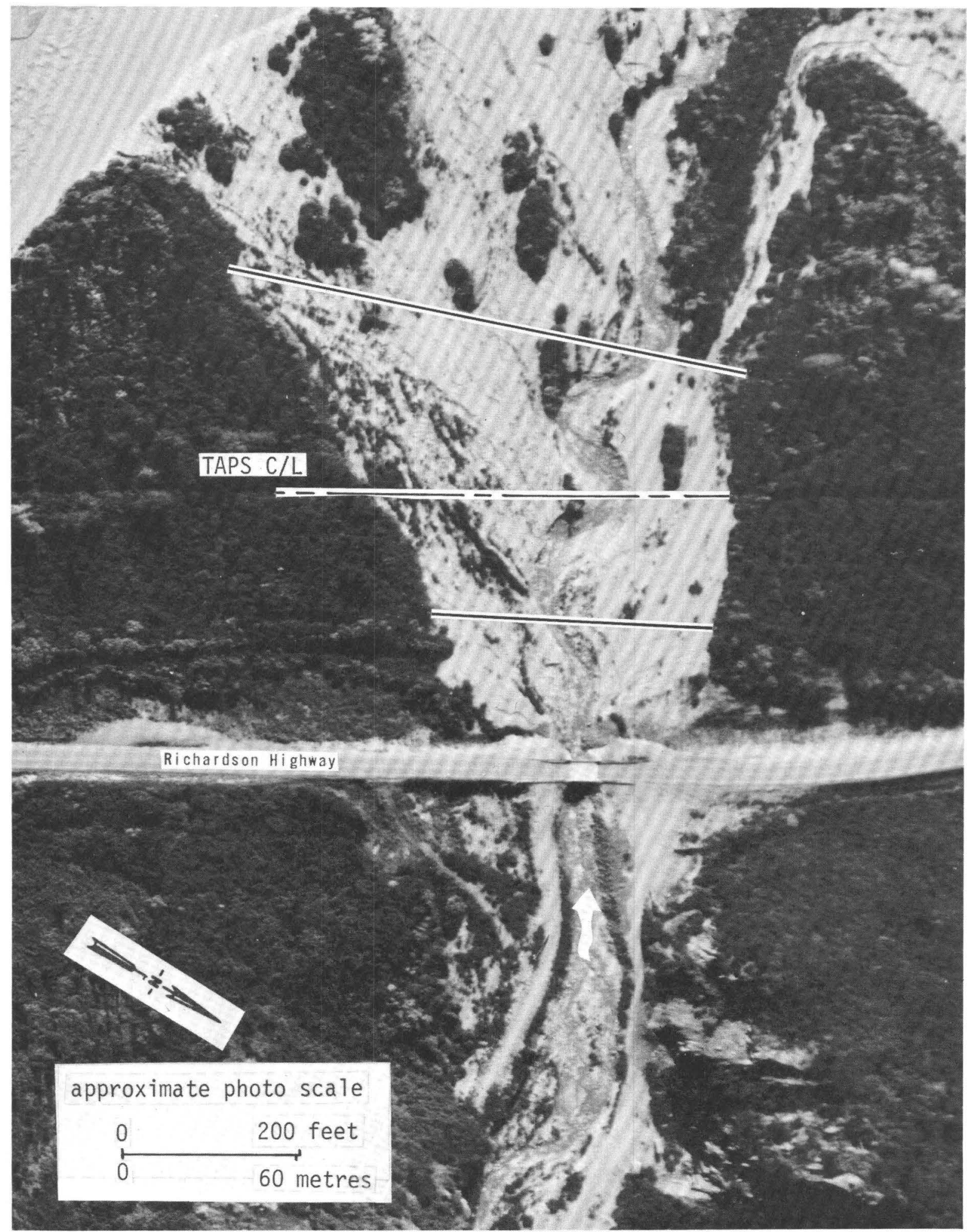

Figure 52. -- Flood Creek near Rapids, August 31, 1974. ALYESKA PIPELINE SERVICE CO.-AIR PHOTO TECH. 


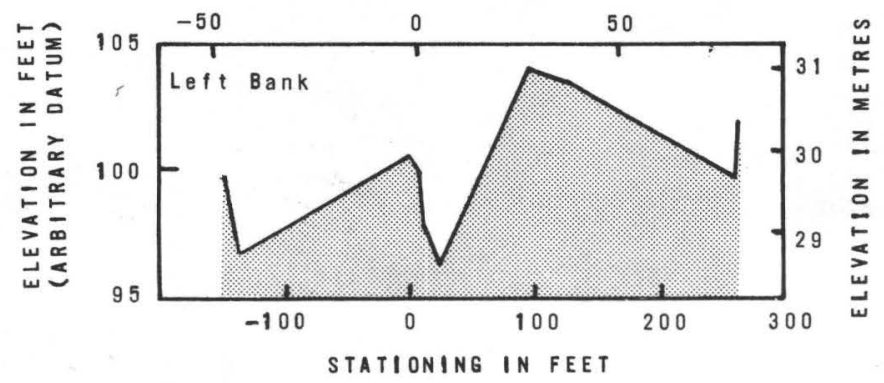

UPSTREAM CROSS SECTION
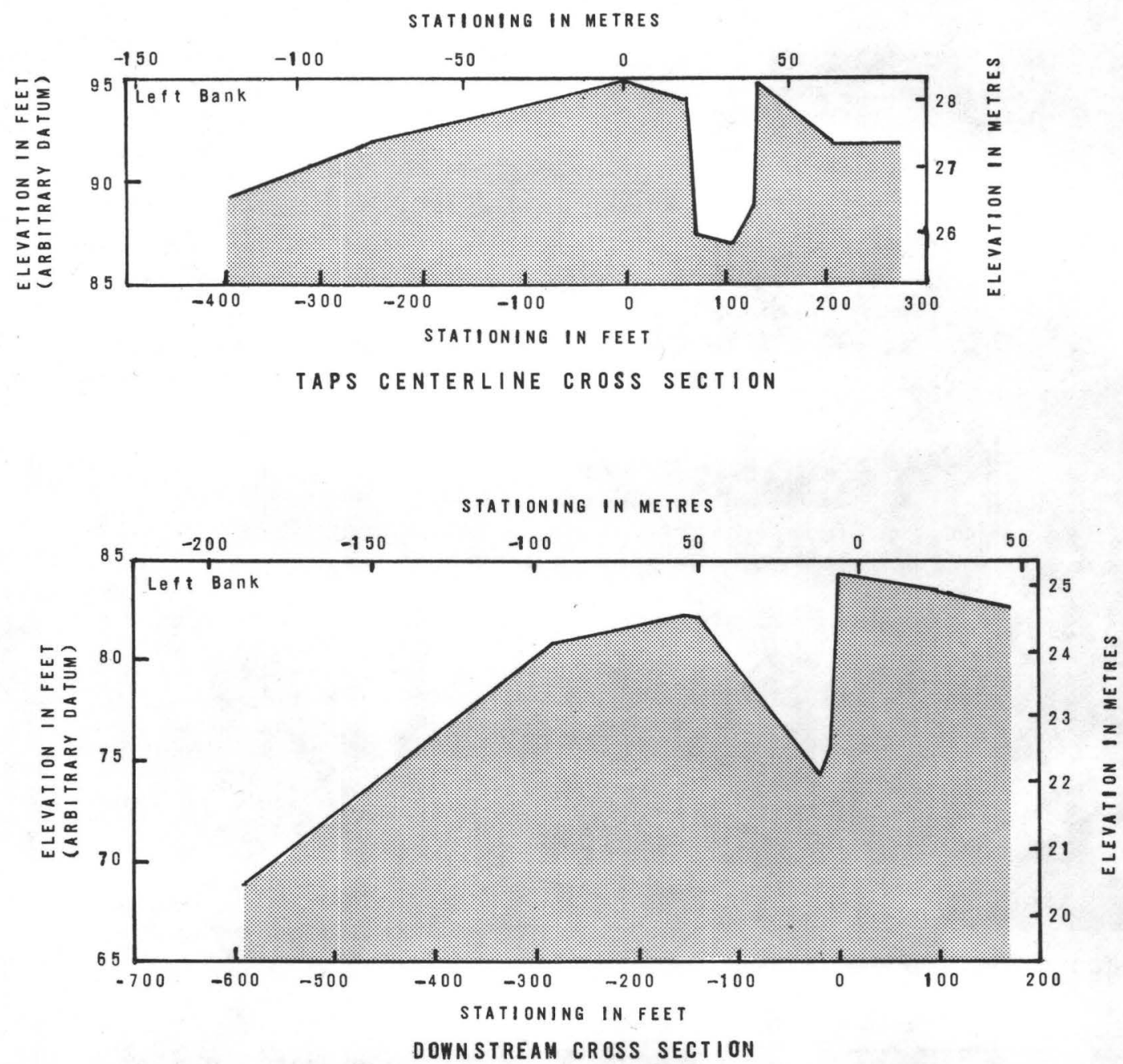

Figure 53. -- Cross sections of Flood Creek near Rapids, Alaska, September 1972. 


\section{Gulkana River near Sourdough}

Location.--Lat $62^{\circ} 32^{\prime} 28^{\prime \prime}$, long $145^{\circ} 32^{\prime} 00^{\prime \prime}$, in SE $\frac{1}{4} \mathrm{sec} .23$, T.9 N., R.2 W., at pipeline crossing, $1.5 \mathrm{mi}(2.4 \mathrm{~km})$ upstream from Sourdough Creek, and about $1 \mathrm{mi}(2 \mathrm{~km})$ northwest of Sourdough. [Gulkana (C-4) 1:63,360, U.S. Geological Survey map.]

Channel conditions.--Low-altitude vertical aerial stereophotography (scale 1:2,400) was obtained September 23, 1972, (fig. 54) to document preconstruction topography at the site. Vertical aerial strip photography (scale 1:6,000) taken August 31, 1974, (fig. 55) shows no significant channel erosion or construction activities have occurred in the crossing reach since September 23, 1972. Six cross sections (fig. 56) were surveyed May 15, 1973, to define preconstruction ground profiles in the crossing reach. On May 23, 1974, a channel erosion survey was made at a streamflow discharge of $6,430 \mathrm{ft}^{3} / \mathrm{s}\left(182 \mathrm{~m}^{3} / \mathrm{s}\right)$, gage height, $6.72 \mathrm{ft}$ (205 m) at gaging station just downstream from Sourdough Creek, to determine maximum streambed scour at the cross sections.

The survey found $15 \mathrm{ft}(5 \mathrm{~m})$ of lateral bank erosion along the right bank of section 4 and along the left bank of section 5 . Two feet $(0.6 \mathrm{~m})$ of scour was measured.

Floods.--No significant overbank flooding occurred during the period September 23, 1972, through August 31, 1974. The maximum observed discharge for the period, $8,840 \mathrm{ft}^{3} / \mathrm{s}\left(250 \mathrm{~m}^{3} / \mathrm{s}\right)$ (fig. 57), was confined to the main channel below the maximum evident flood and bankfull stage. 


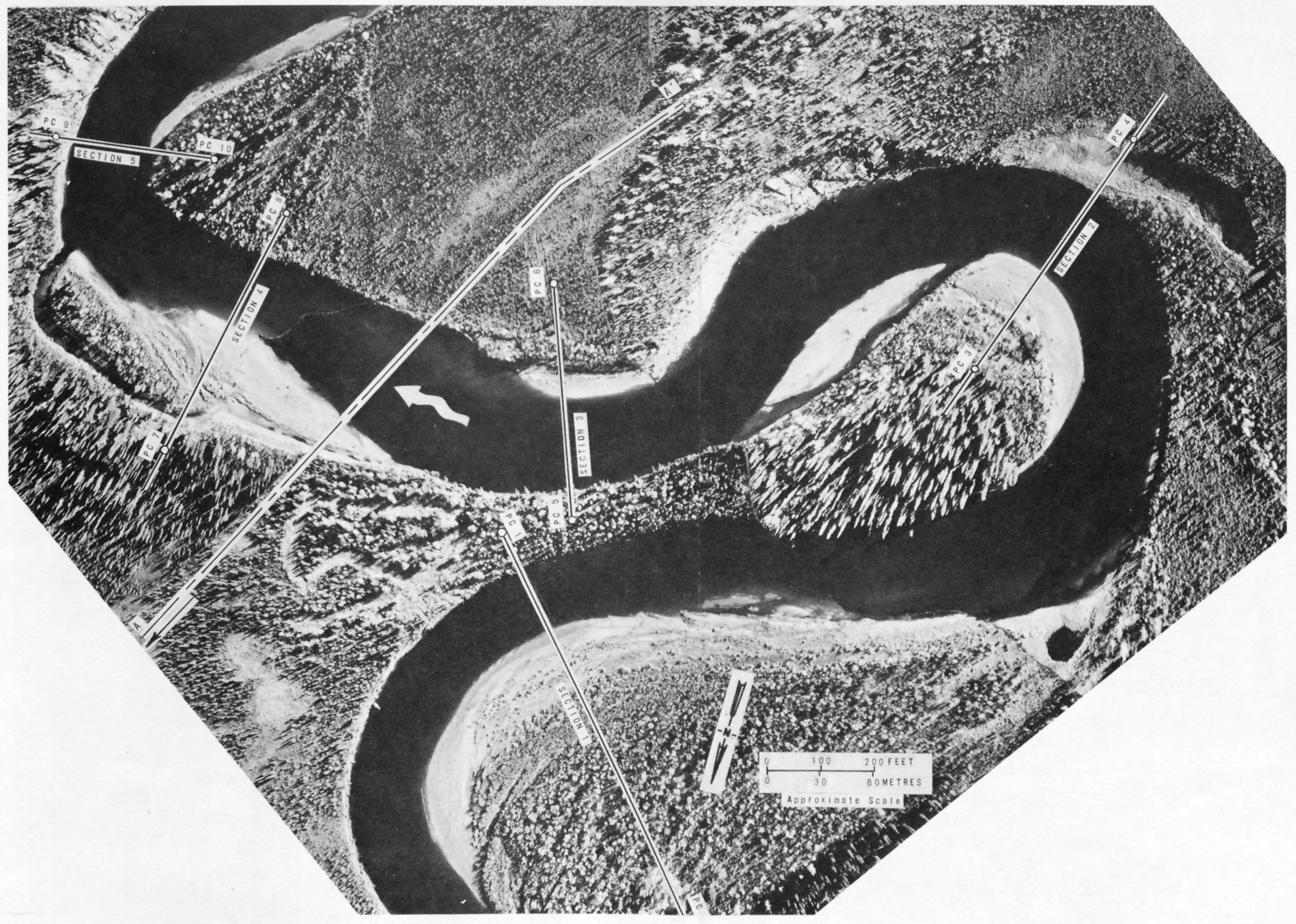

Figure 54. -- Gulkana River near Sourdough, September 23, 1972. NoRTH PACIFIC AERIAL SURveYS 


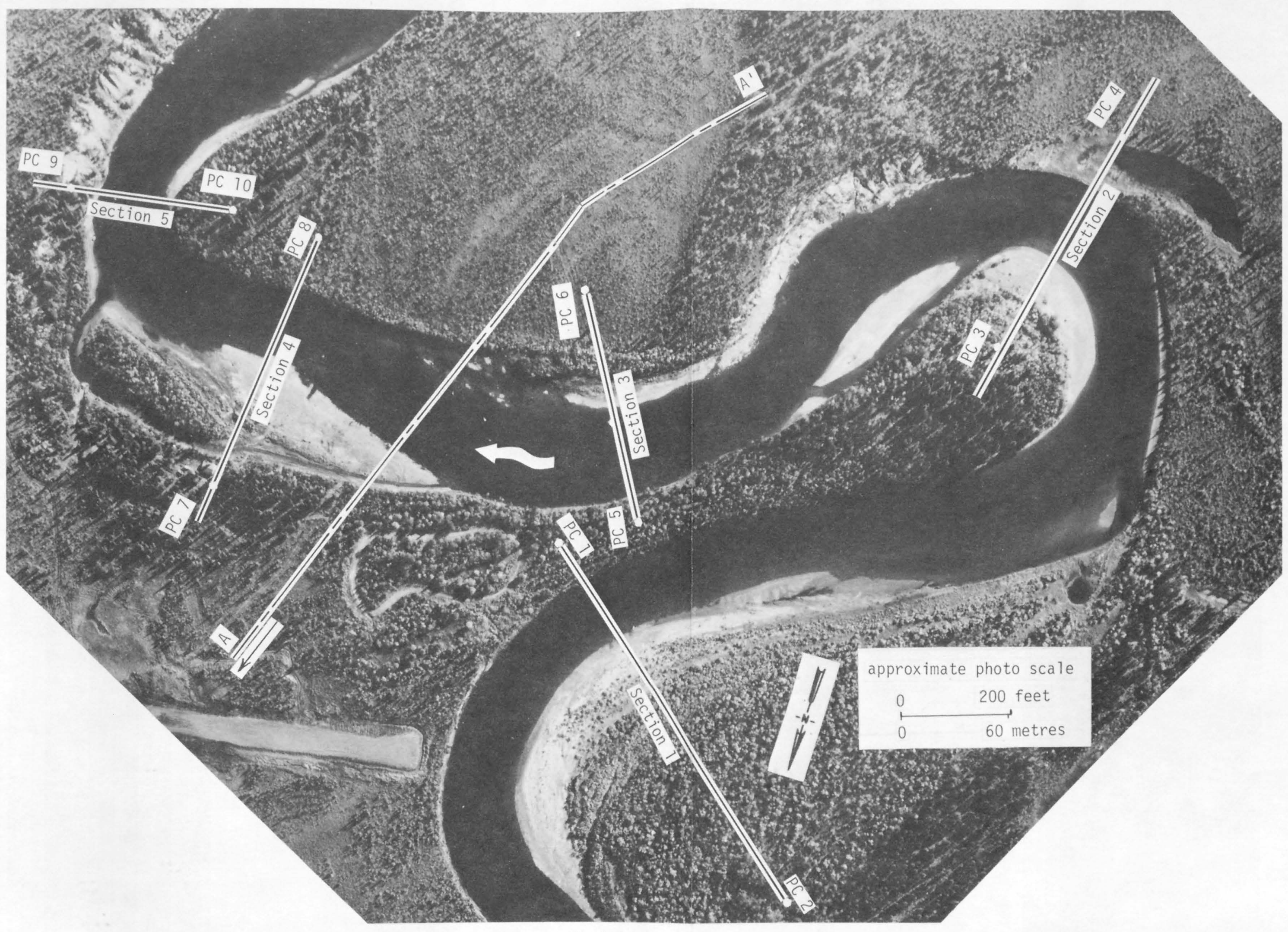

Figure 55. -- Gulkana River near Sourdough, August 31, 1974. alyeska PIPELINE SERVICE CO.-AIR PHOTO TECH. 

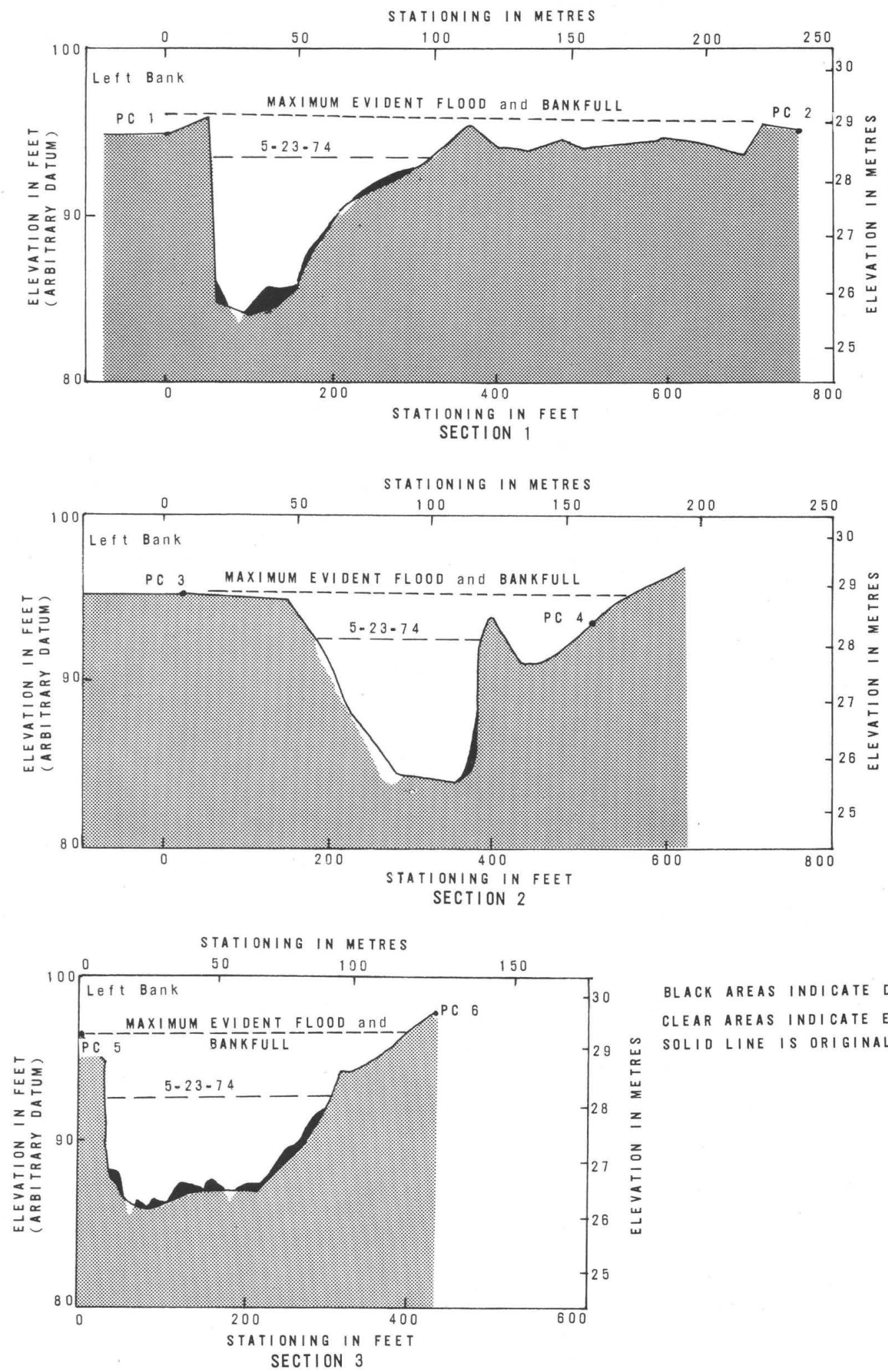

BLACK AREAS INDICATE DEPOSITION, CLEAR AREAS INDICATE EROSION, SOLID LINE IS ORIGINAL SECTION.

Figure 56. -- Cross sections of the Gulkana River near Sourdough, Alaska, May 15, 1973, and May 23, 1974. 
STATIONING IN METRES

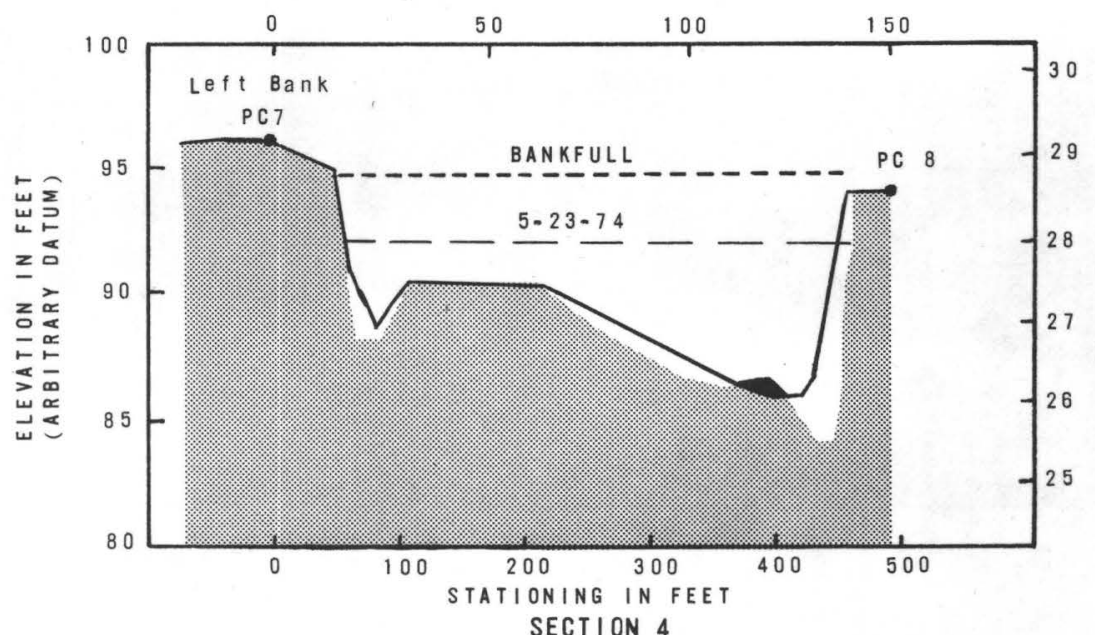

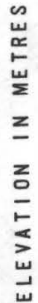

BLACK AREAS INDICATE DEPOSITION.

CLEAR AREAS INDICATE EROSION,

SOLID LINE IS ORIGINAL SECTION.

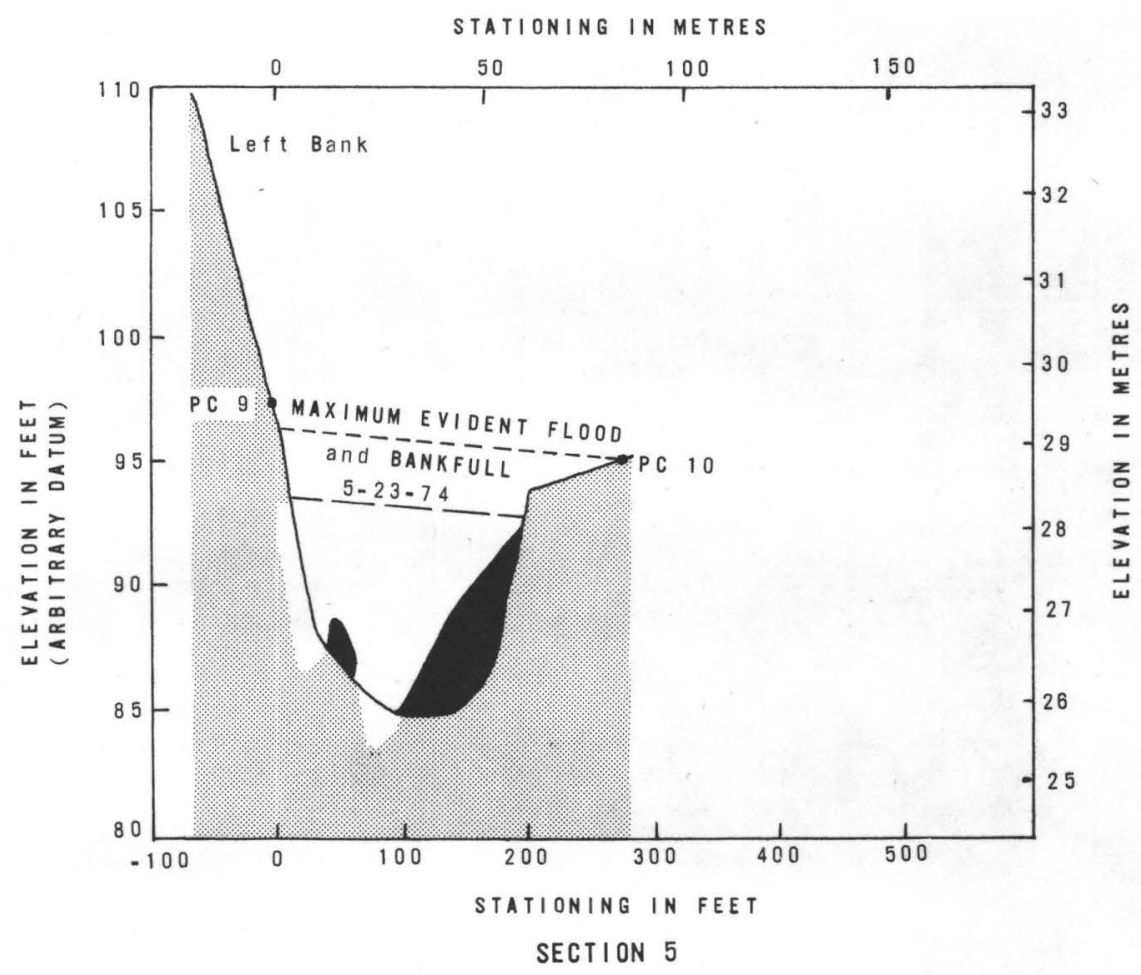

Figure 56. -- Cross sections of the Gulkana River near Sourdough, May 15, 1973, and May 23, 1974 -.- Continued. 
STATIONING IN METRES

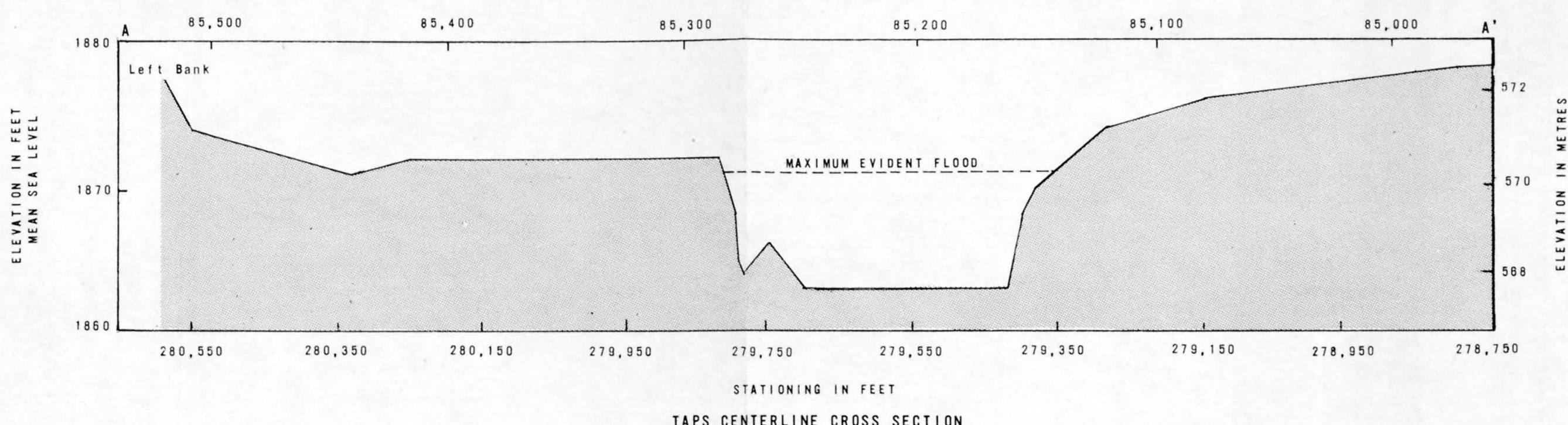

TAPS CENTERLINE CROSS SECTION

FROM ALYESKA PIPELINE SERVICE CO. SURVEY

Figure 56---Cross sections of the Gulkana River near Sourdough, Alaska, May 15, 1973 and May 23, 1974 ---Continued. 

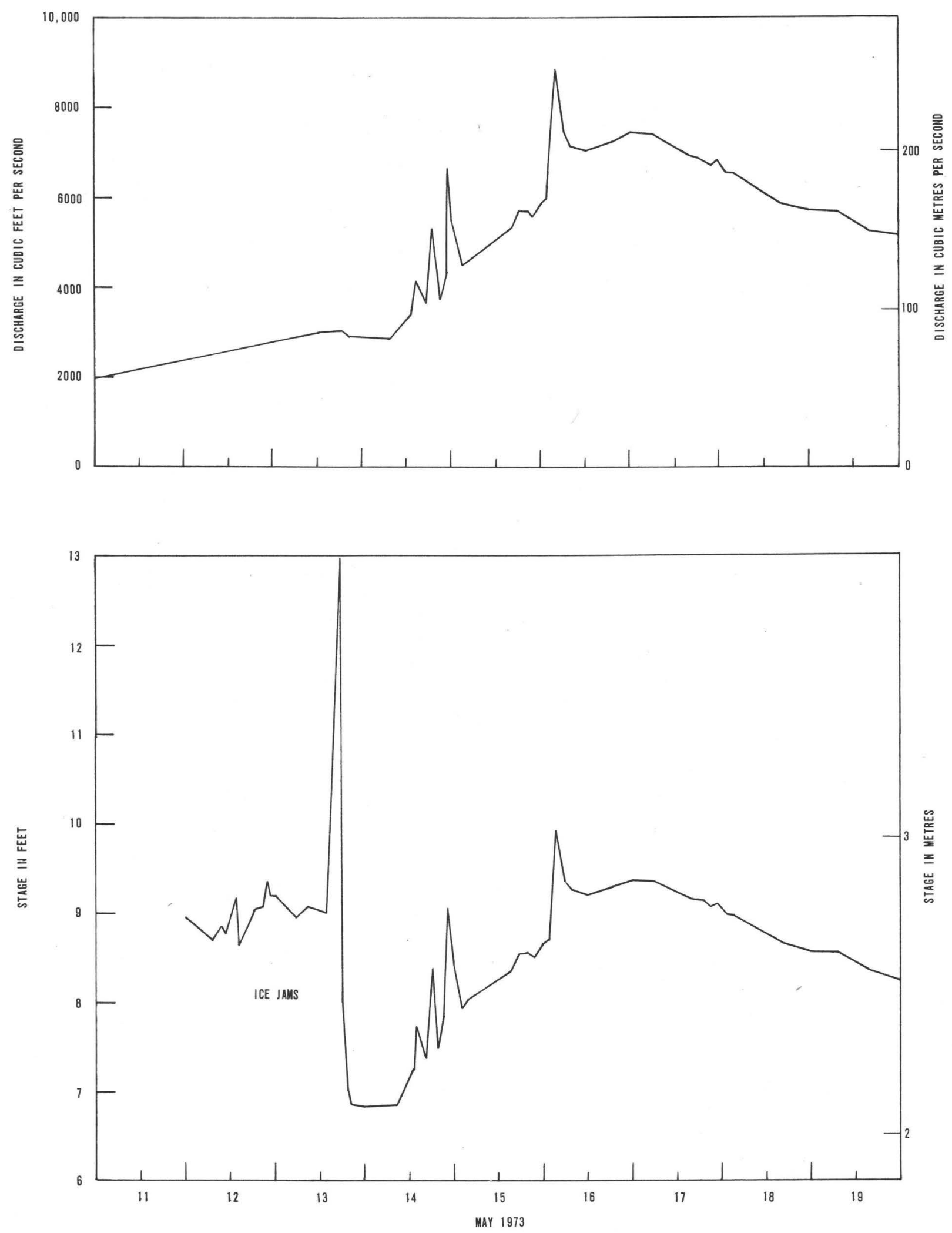

Figure 57.-- Discharge and stage hydrograph for Gulkana River near Sourdough. 


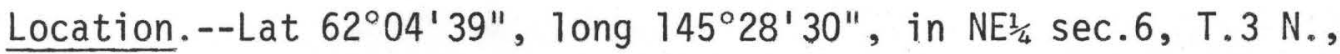
R.1 W., at pipeline crossing, $0.1 \mathrm{mi}(0.2 \mathrm{~km})$ downstream from Moose Creek, and $2.5 \mathrm{mi}(6.4 \mathrm{~km})$ southeast of Glennallen. [Gulkana (A-3) 1:63,360, U.S. Geological Survey map.]

Channel conditions.--Low-altitude vertical aerial stereophotography (scale 1:2,400) was obtained September 23, 1972, (fig. 58) to document preconstruction topography of the site. Vertical aerial strip photography (scale 1:6,000) taken August 31, 1974, (fig. 59) shows no significant channel erosion or construction activities have occurred in the proposed crossing reach since September 23, 1972. Three cross sections (fig. 60) were surveyed September 22, 1973, to define preconstruction ground profiles in the crossing reach. On September 18, 1974, a channel survey of the original cross sections following the flood of August 15, 1974, shows $1 \mathrm{ft}$ $(0.3 \mathrm{~m})$ of general scour in the crossing reach. There were no construction activities at the crossing.

Floods.--Tazlina Lake's glacier-dammed outburst flood peaked at a discharge of $43,100 \mathrm{ft}^{3} / \mathrm{s}\left(1,221 \mathrm{~m}^{3} / \mathrm{s}\right)$ (fig. 61) at the crossing reach.

Comparison of aerial stereophotographs of September 23, 1972, (Childers, 1975, fig. 12) and June 15, 1974, of the meander downstream from the crossing shows no channel change at the meander neck A (fig. 62). (See discussion in Childers, 1975, p. 19.) The flood of August 15, 1974, overflowed the meander loop B, has begun to cut a channel there, and overflowed the bank along the area at $C$. Figure 63 shows the changes in the cross section at the bridge, site $D$. 


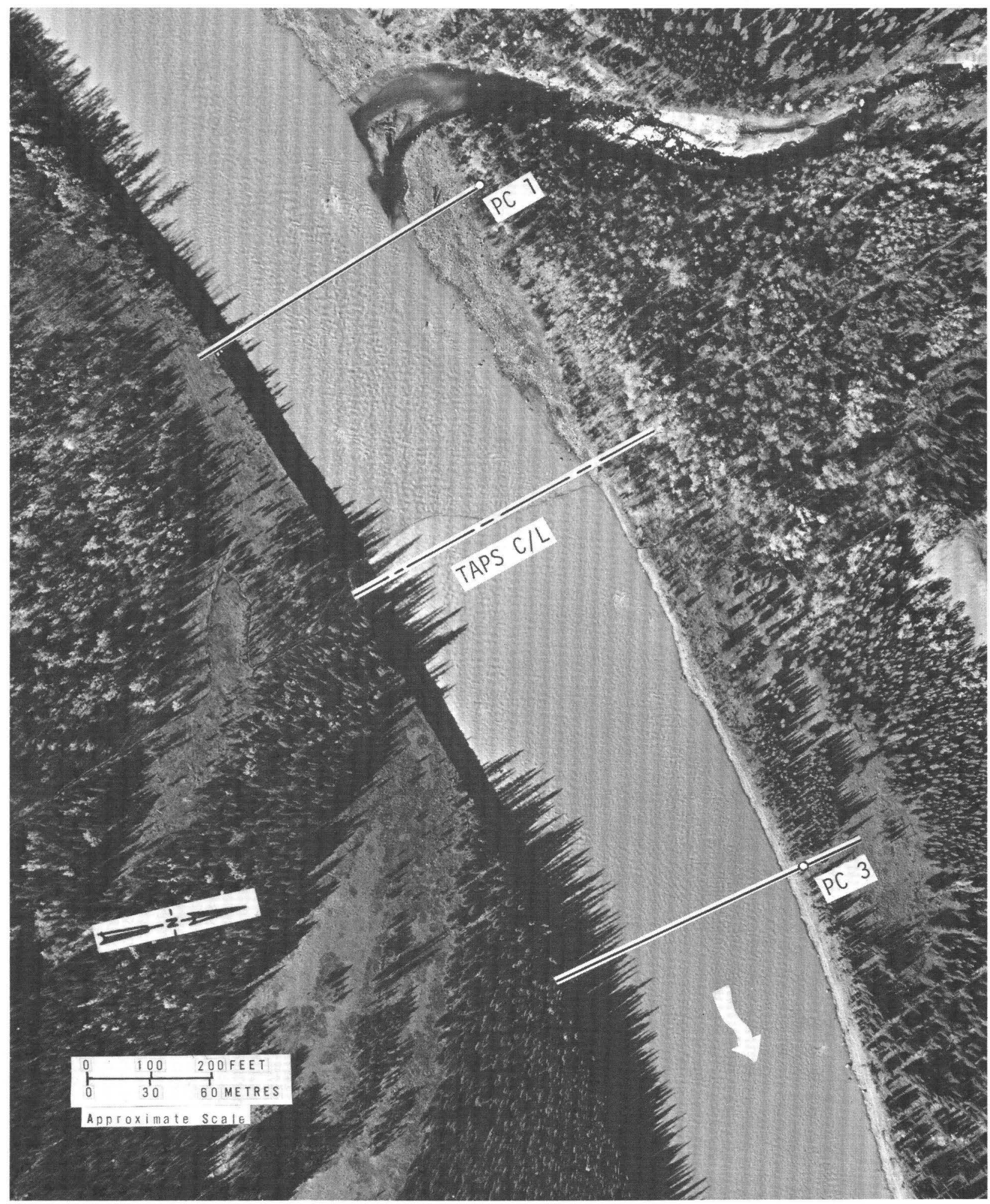

Figure 58. -- Tazlina River near Glennallen, September 23, 1972. NORTH PACIFIC AERIAL SURVEYS 


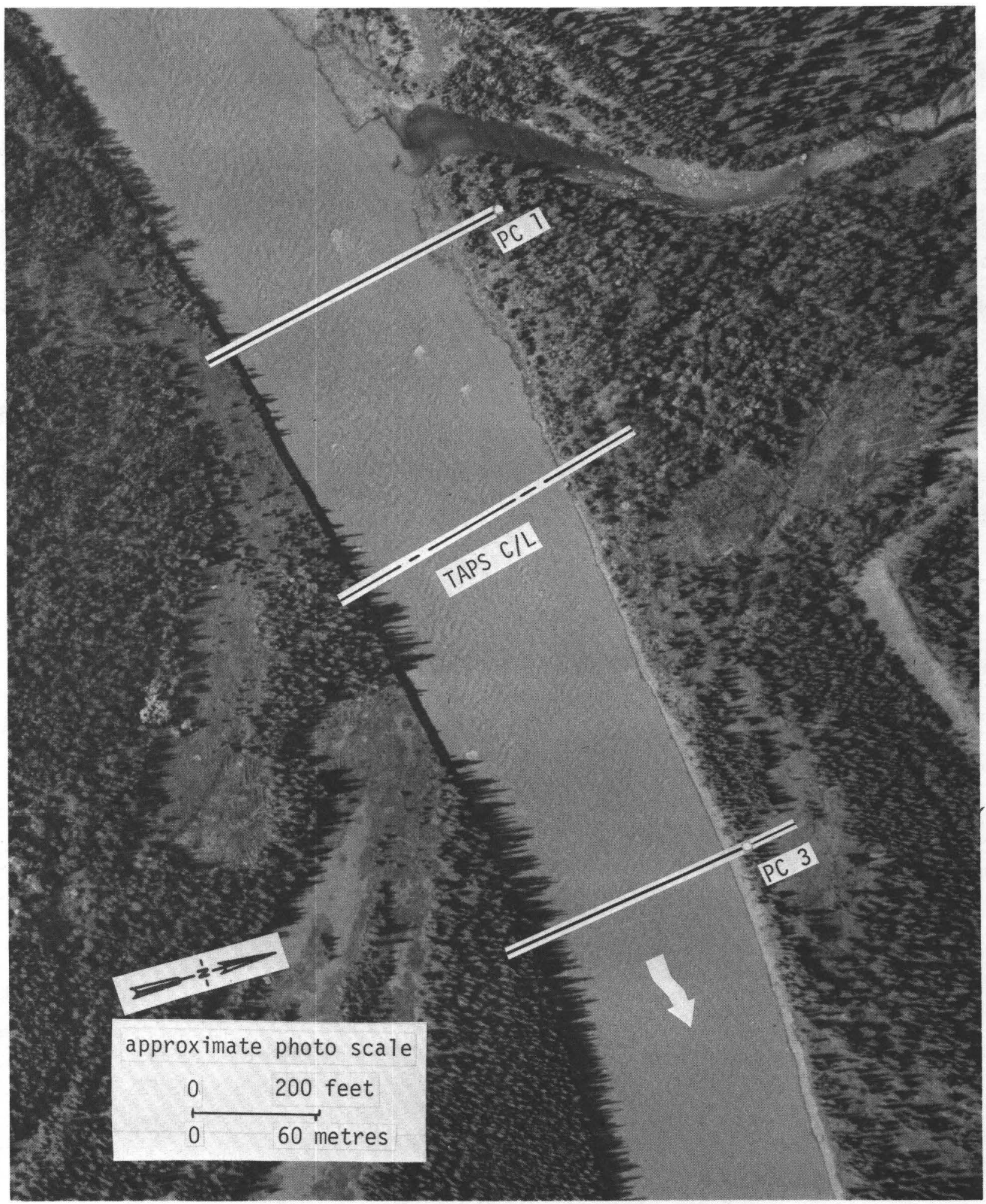

Figure 59. -- Tazlina River near Glennallen, August 31, 1974. ALYESKA PIPELINE SERVICE CO.-AIR PHOTO TECH. 

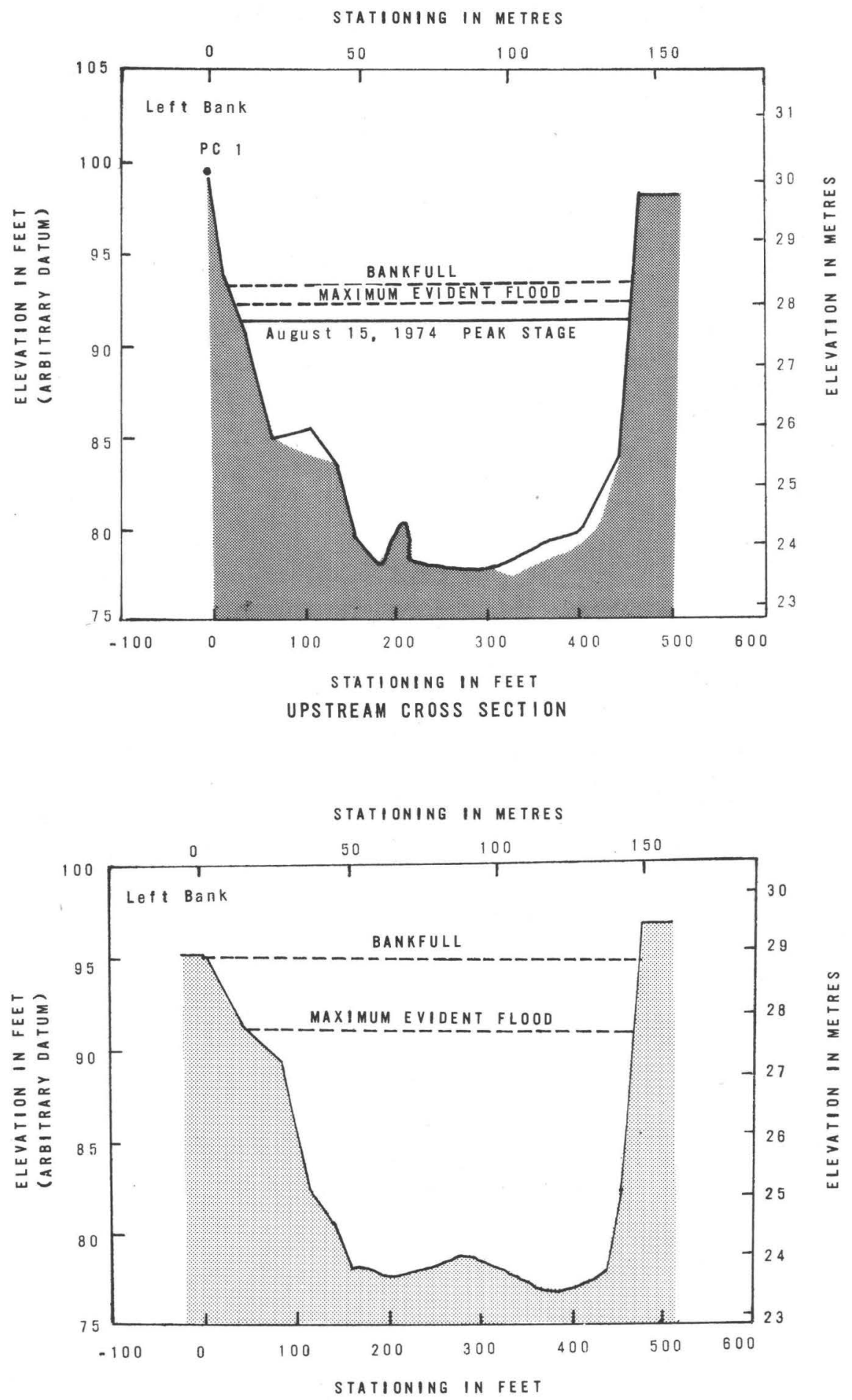

TAPS CENTERLINE CROSS SECTION

Figure 60. -- Cross sections of the Tazlina River near Glennallen, Alaska August 22, 1973 and September 18, 1974. 


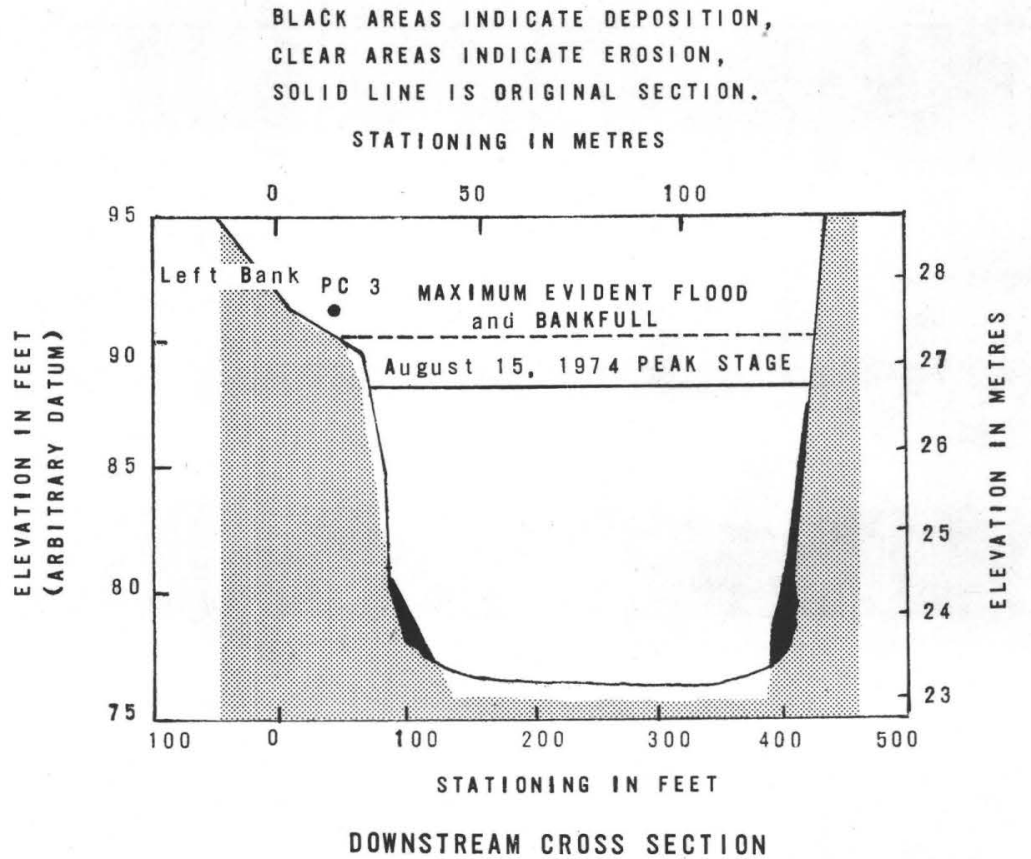

Figure 60.--Cross sections of the Tazlina River near Glennallen, Alaska August 22, 1973 and September 18, 1974 ---Continued. 


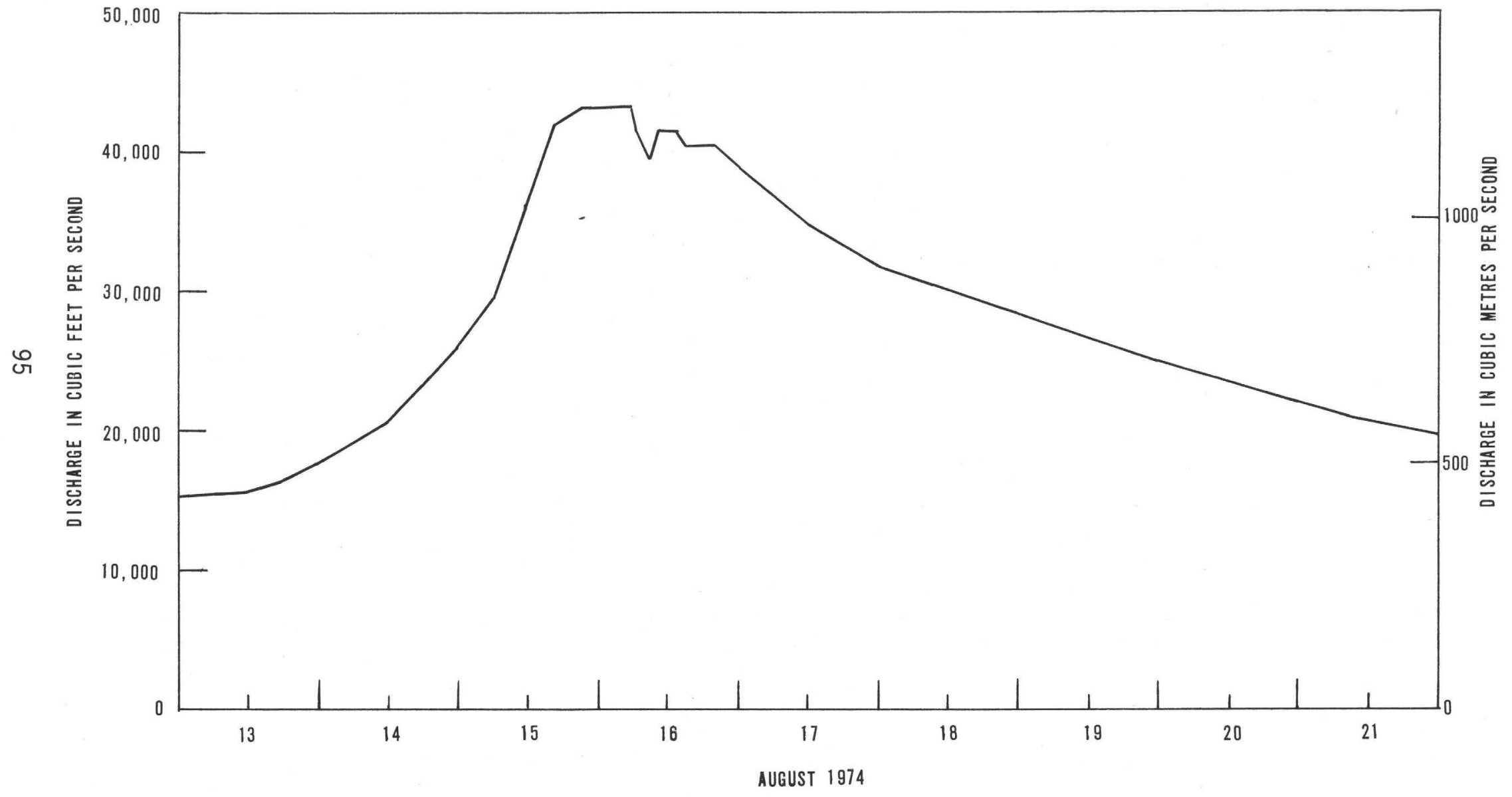

Figure 61.-- Discharge hydrograph for Tazlina River near Glennallen. 


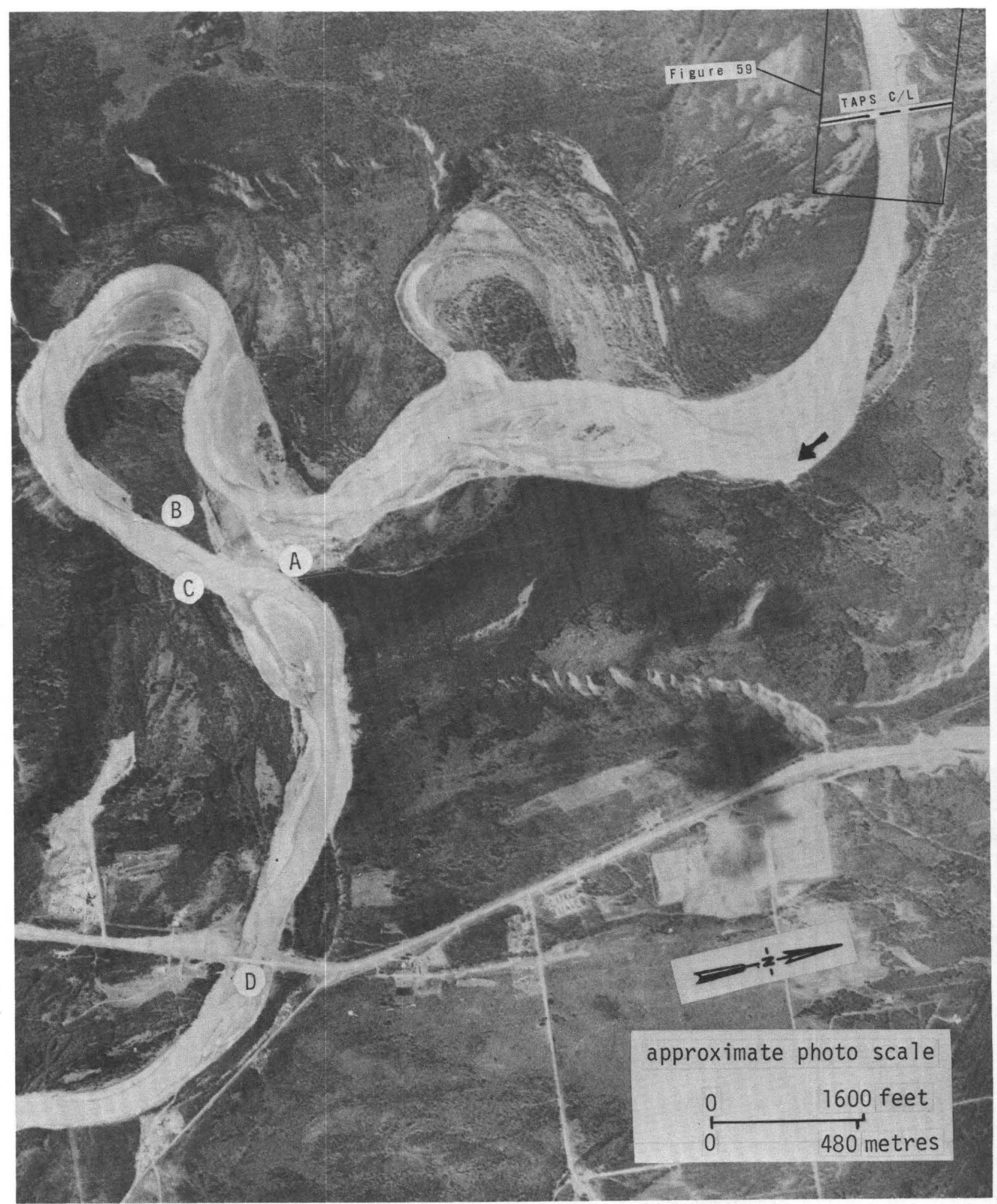

Figure 62. -- Tazlina River near Glennallen, June 15, 1974. NORTH PACIFIC AERIAL SURVEYS 


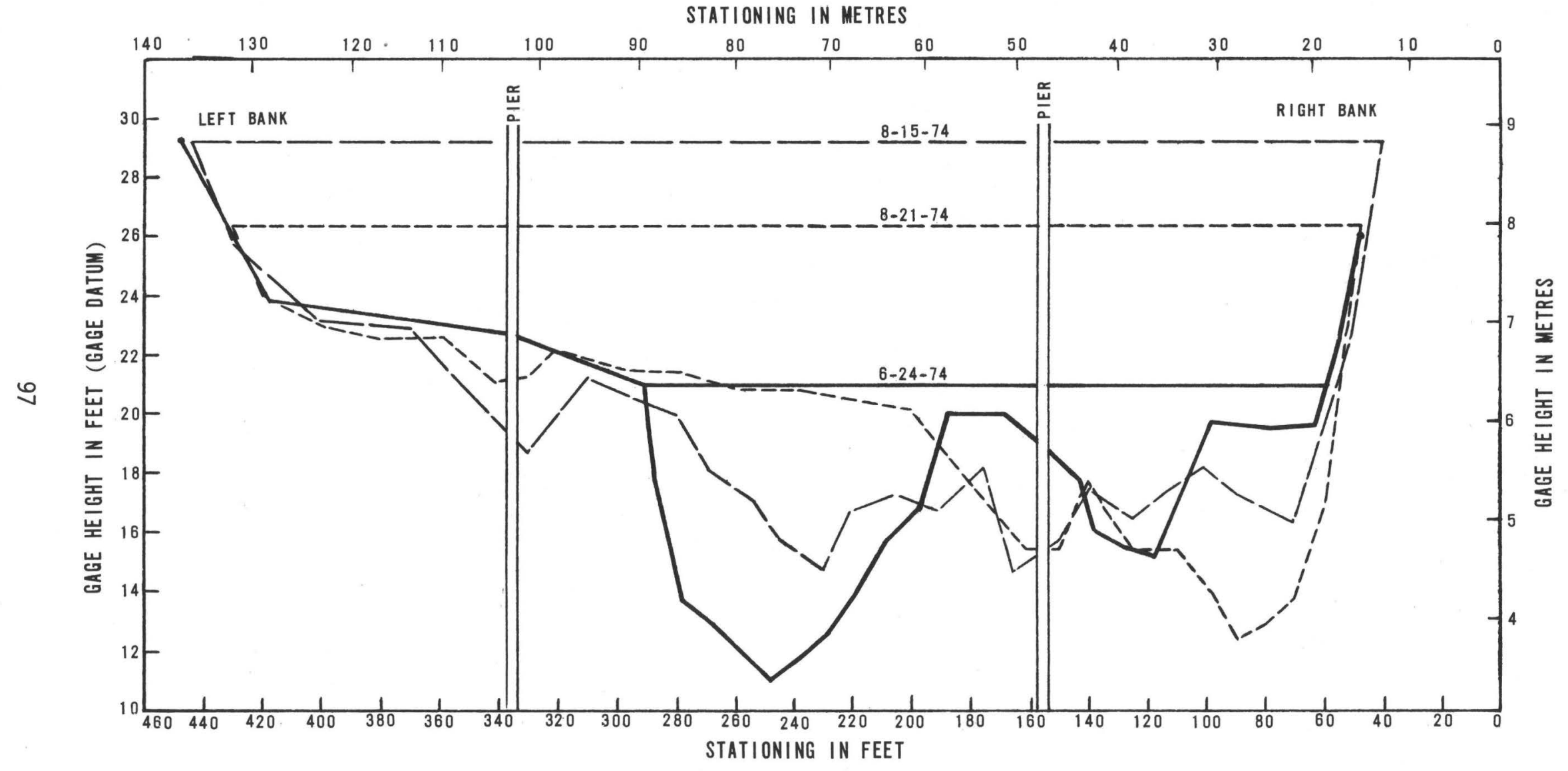

Figure 63. -- Cross sections of the Tazlina River near Glennallen at highway bridge, June 24, 1974, August 15, 1974 and August 24, 1974. 


\section{Klutina River near Copper Center}

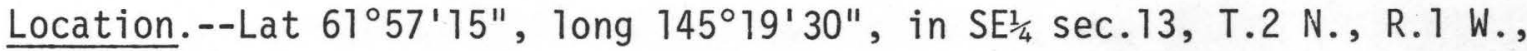
at pipeline crossing $1.5 \mathrm{~m}(2.4 \mathrm{~km})$ upstream from Copper River, and $1 \mathrm{mi}(2 \mathrm{~km})$ west of Copper Center.

[Valdez (D-4) 1:63,360, U.S. Geological Survey map.]

Channel conditions.--Low-altitude vertical aerial stereophotography (scale 1:6,000) was obtained May 22, 1973, (fig. 64) to document preconstruction topography at the site. Vertical aerial strip photography (scale 1:6,000) taken August 31, 1974, (fig. 65) shows no significant channel erosion or construction activities have occurred in the crossing reach since May 22, 1973. The TAPS centerline section surveyed by Alyeska Pipeline Service Company on August 14, 1970, is shown in figure 66.

Floods.--No significant overbank flooding occurred during the period of the erosion investigation May 22, 1973, and August 31, 1974. 


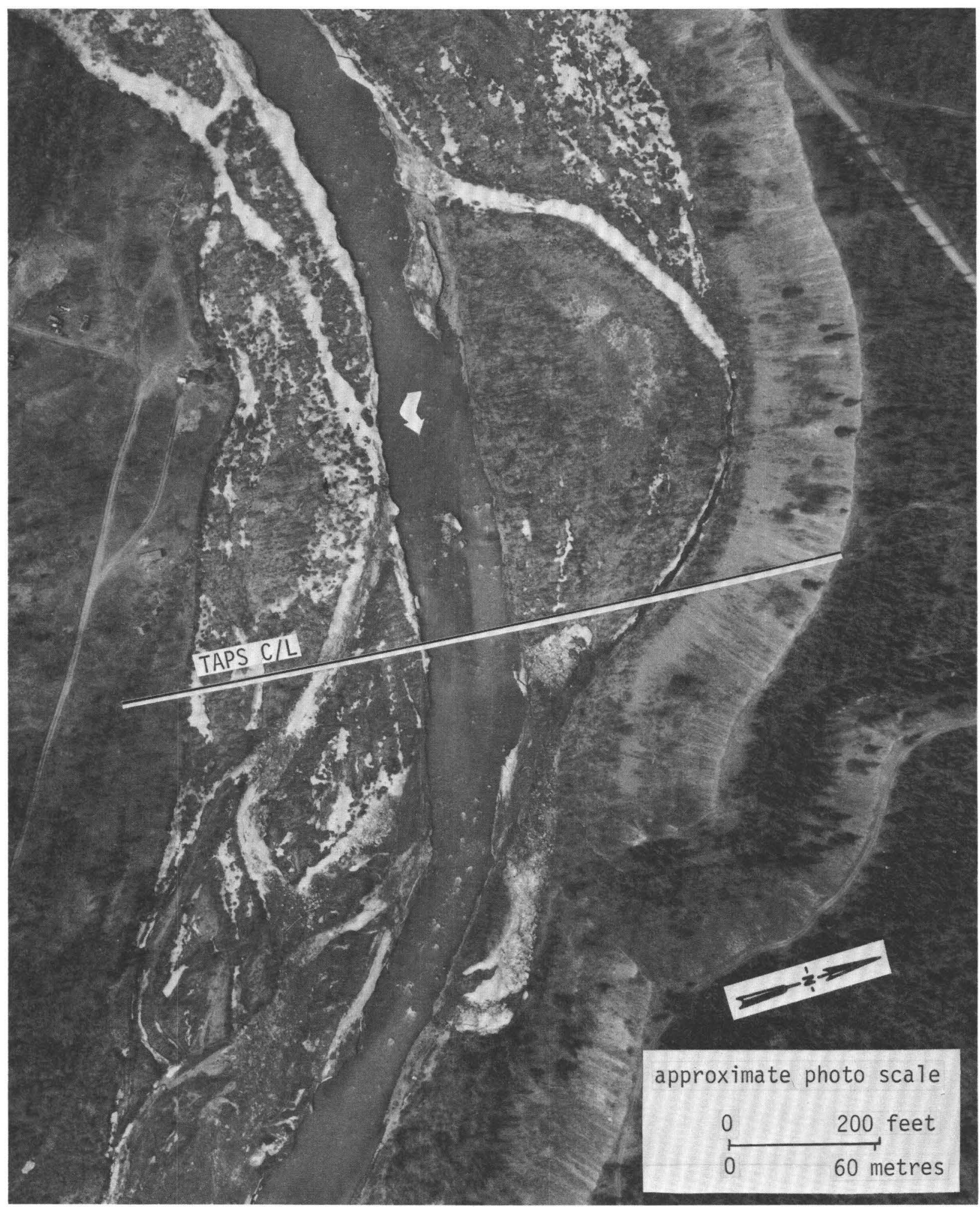

Figure 64. -- Klutina River near Copper Center, May 22, 1973. ALYESKA PIPELINE SERVICE CO. -AIR PHOTO TECH. 


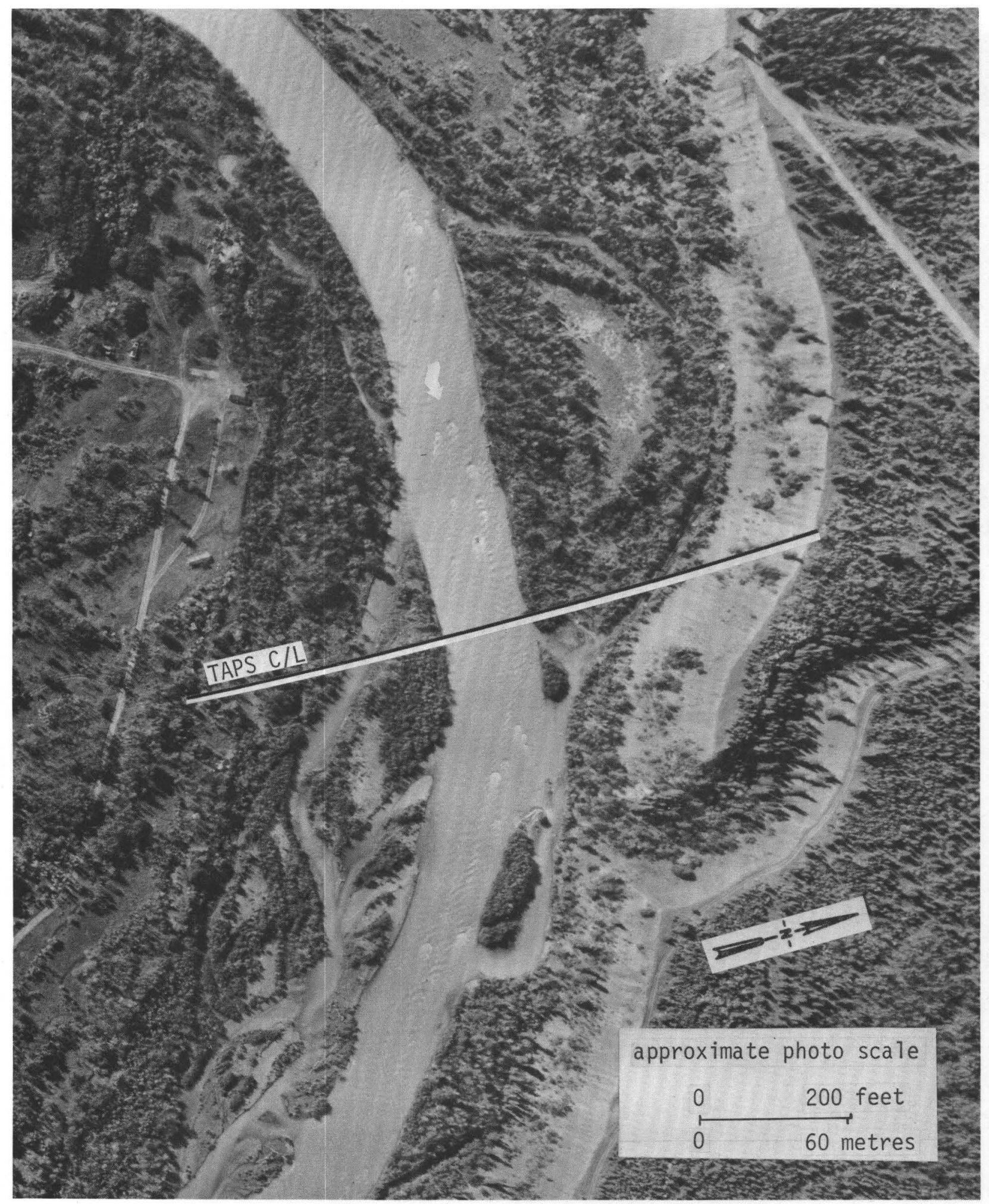

Figure 65. -- Klutina River near Copper Center, August 31, 1974. ALYESKA PIPELINE SERVICE CO.-AIR PHOTO TECH. 
STATIONING IN METRES

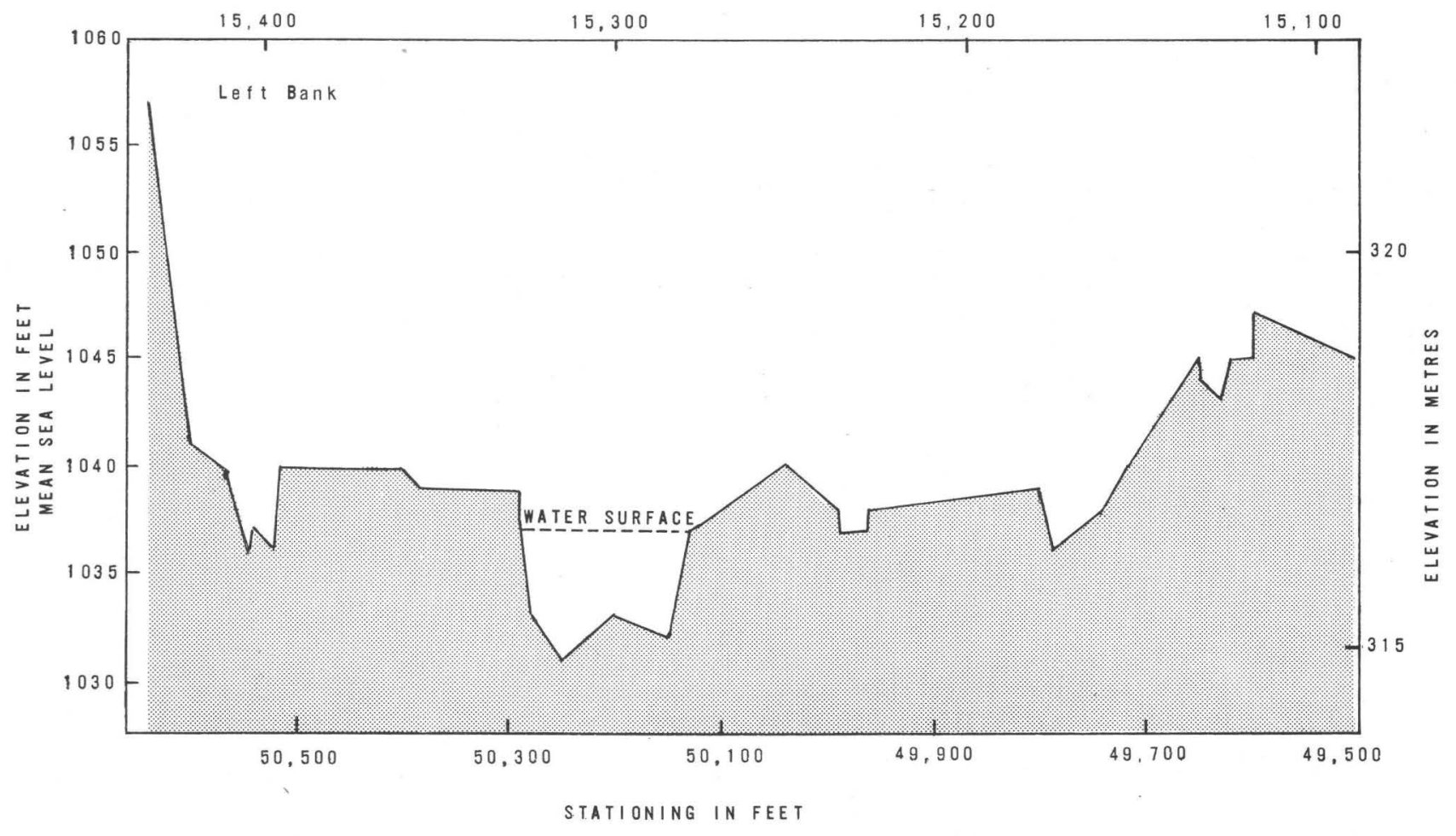

TAPS CENTERLINE CROSS SECTION

Figure 66--Cross section of the Klutina River near Copper Center, Alaska, August 14, 1970. From Alyeska Pipeline Service Co. Survey. 


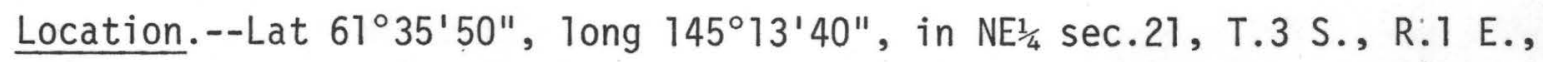
at pipeline crossing, $0.8 \mathrm{mi}(1.3 \mathrm{~km})$ upstream from Little Tonsina River, and $6.5 \mathrm{mi}(10.5 \mathrm{~km})$ south of Tonsina. [Valdez (C-4) 1:63,360, U.S. Geological Survey map.]

Channel conditions.--Low-altitude vertical aerial stereophotography (scale 1:2,400) was obtained September 23, 1972, (fig. 67) to document preconstruction topography at the site. Vertical aerial strip photography (scale 1:6,000) taken August 31, 1974, (fig. 68) shows no significant channel erosion or construction activities have occurred in the crossing reach since September 23, 1972. Three cross sections (fig. 69) were surveyed September 28, 1972, to define preconstruction ground profiles in the crossing reach. On September 1974 a channel survey of the three cross sections found no significant lateral erosion.

Floods.--No significant overbank flooding occurred during the period September 23, 1972, through September 1974. The maximum observed discharge for the period, $3,640 \mathrm{ft}^{3} / \mathrm{s}\left(104 \mathrm{~m}^{3} / \mathrm{s}\right.$ ) (fig. 70 ), was confined to the main channel and below the maximum evident flood and bankfull stage. 


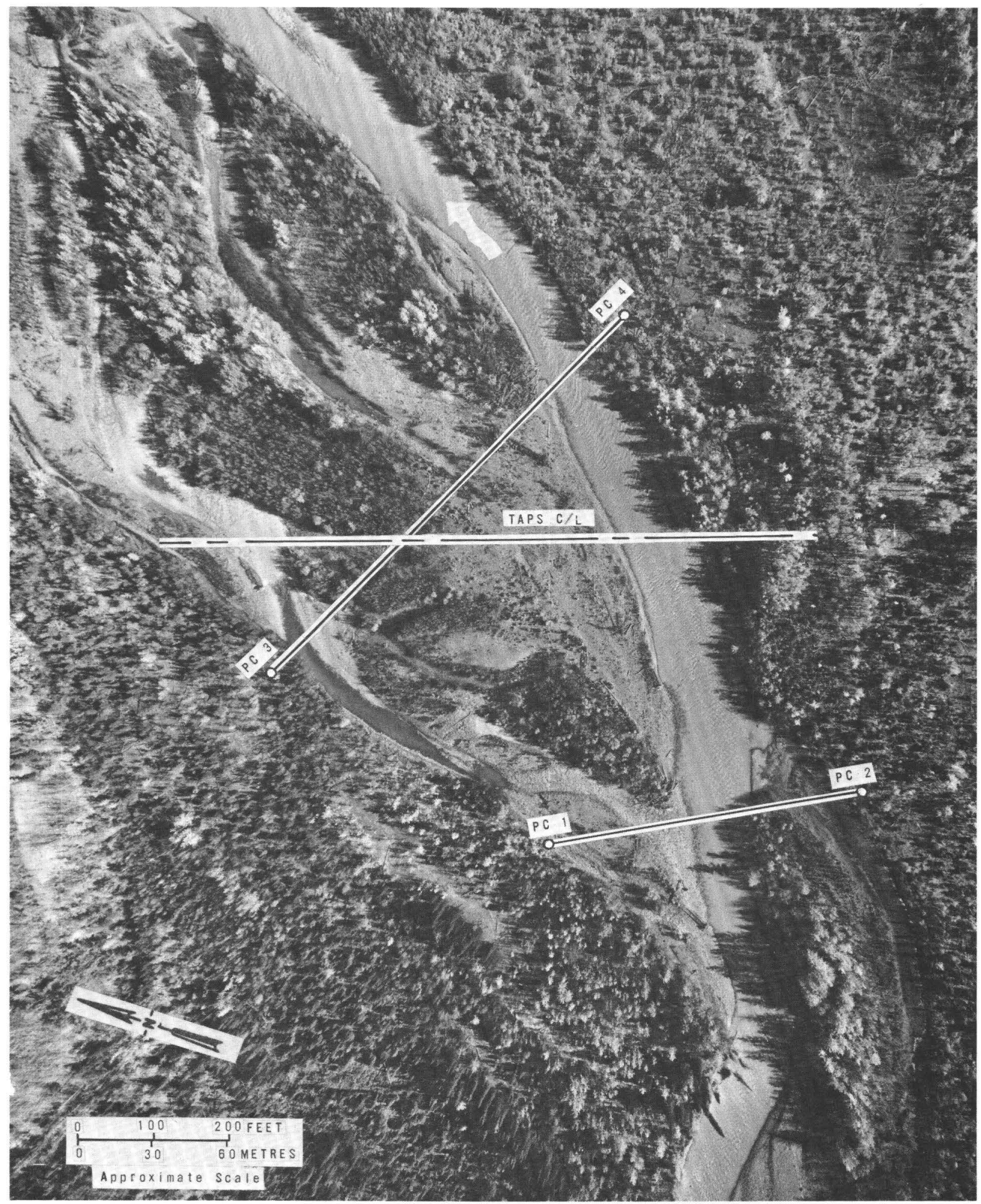

Figure 67. -- Tonsina River near Tonsina, September 23, 1972. NORTH PACIFIC AERIAL SURVEYS 


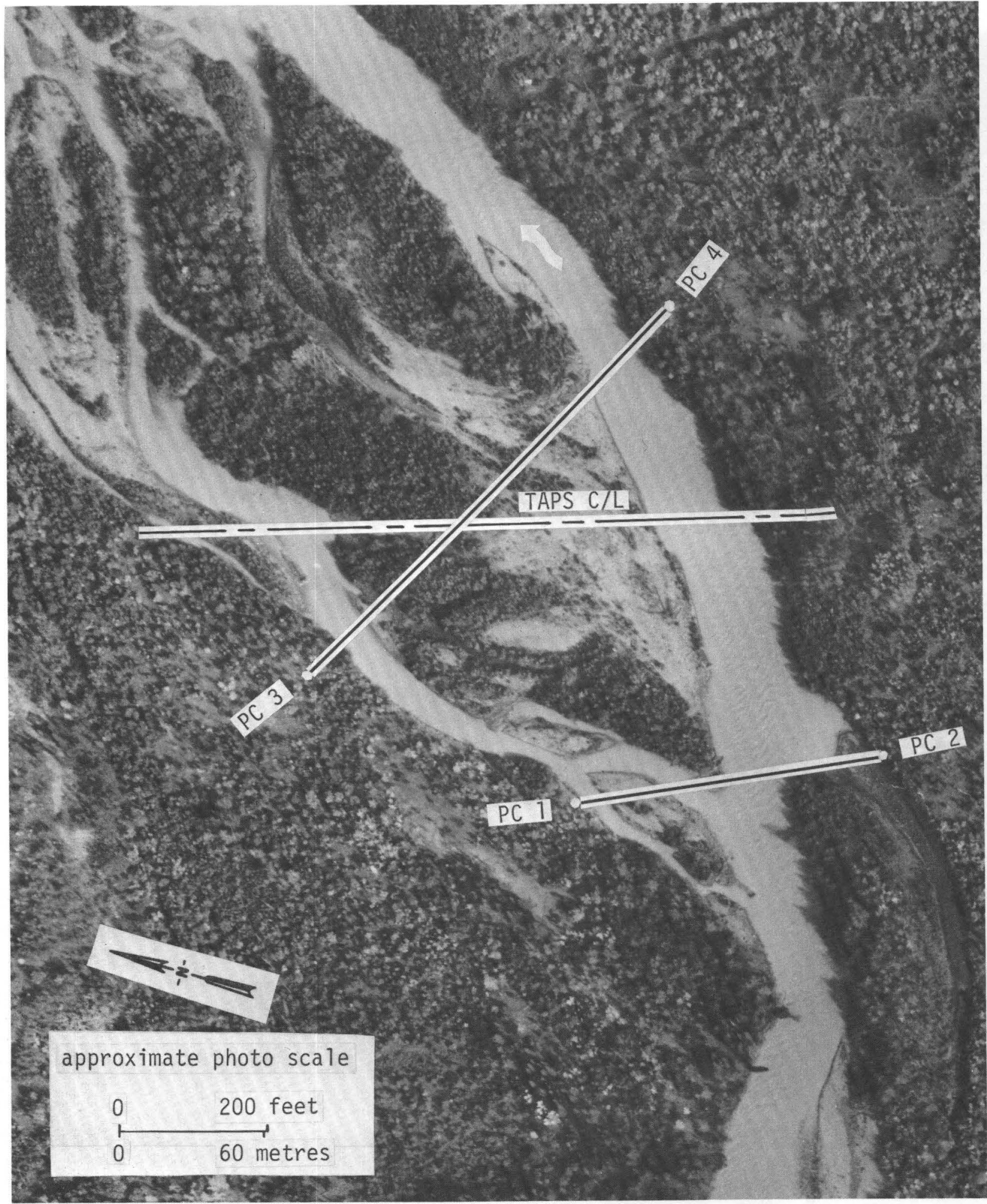

Figure 68. -- Tonsina River near Tonsina, August 31, 1974. ALYESKA PIPELINE SERVICE CO.-AIR. PHOTO TECH. 


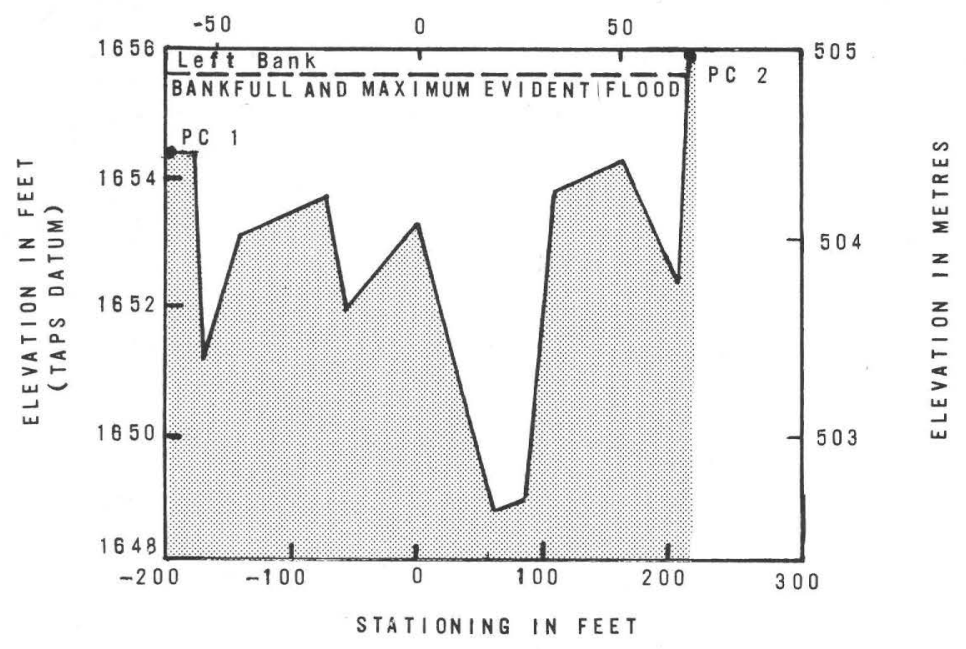

UPSTREAM CROSS SECTION

STATIONING IN METRES

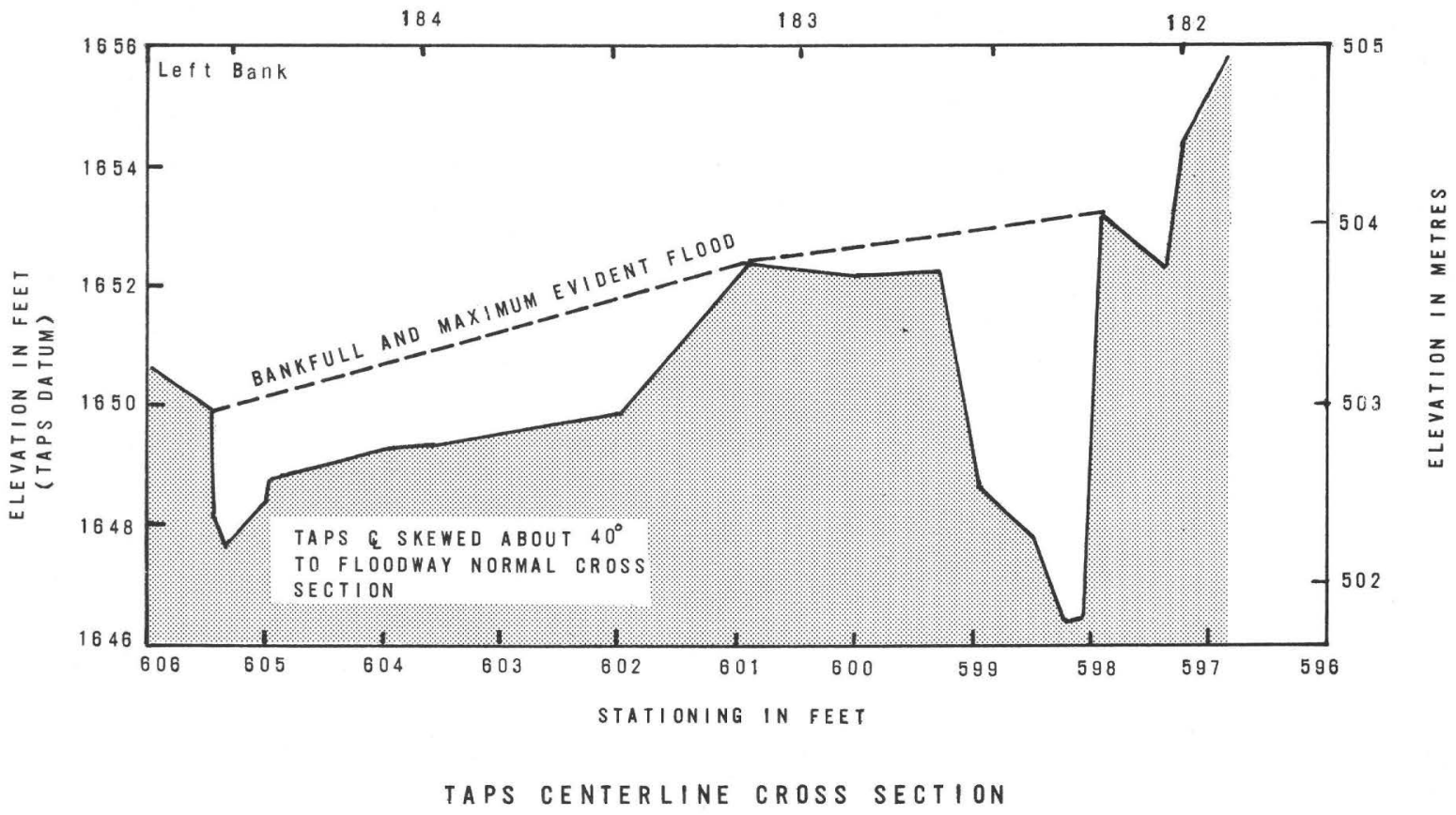

Figure 69--Cross sections of the Tonsina River near Tonsina, Alaska September 28, 1972. 


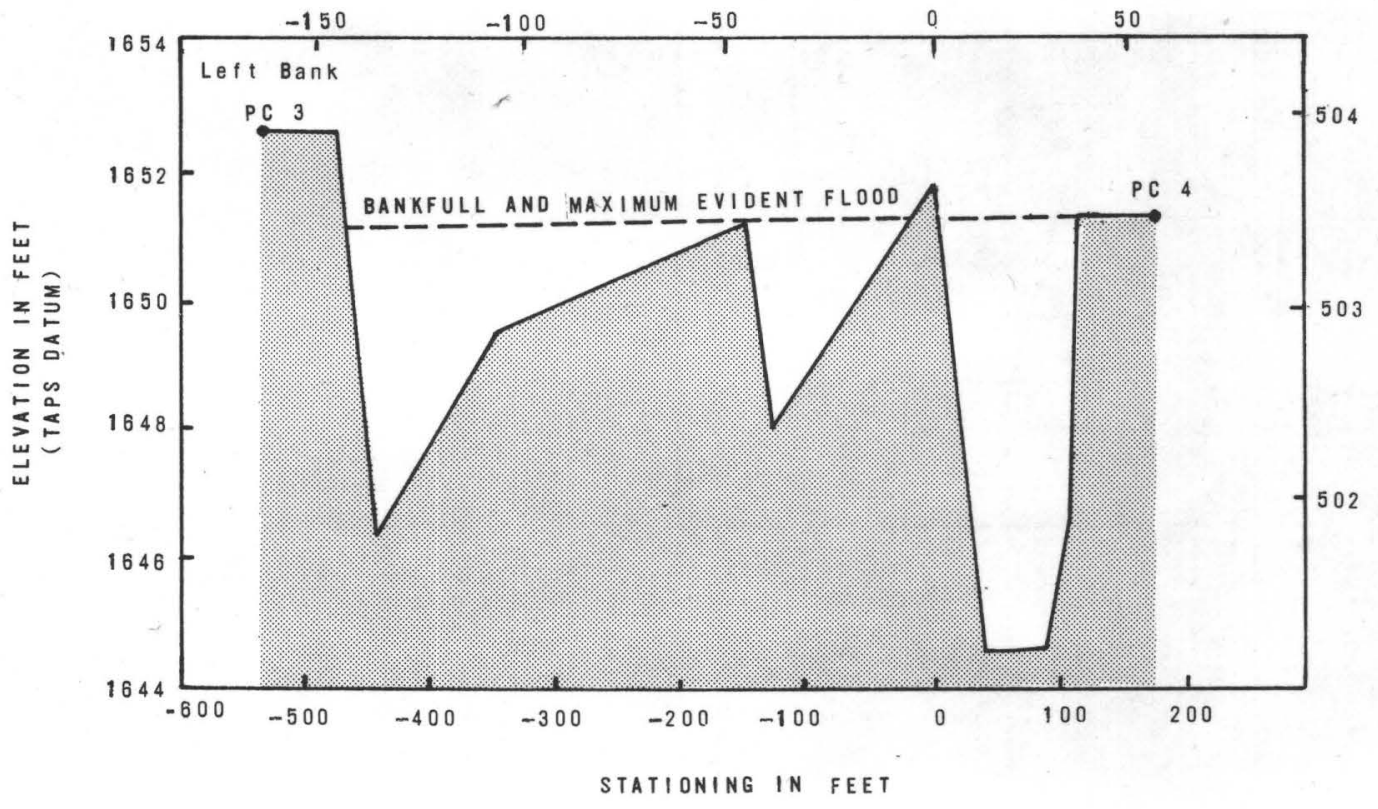

DOWNSTREAM CROSS SECTION

Figure 69--Cross sections of the Tonsina River near Tonsina, Alaska, September 28, 1972-- Continued. 


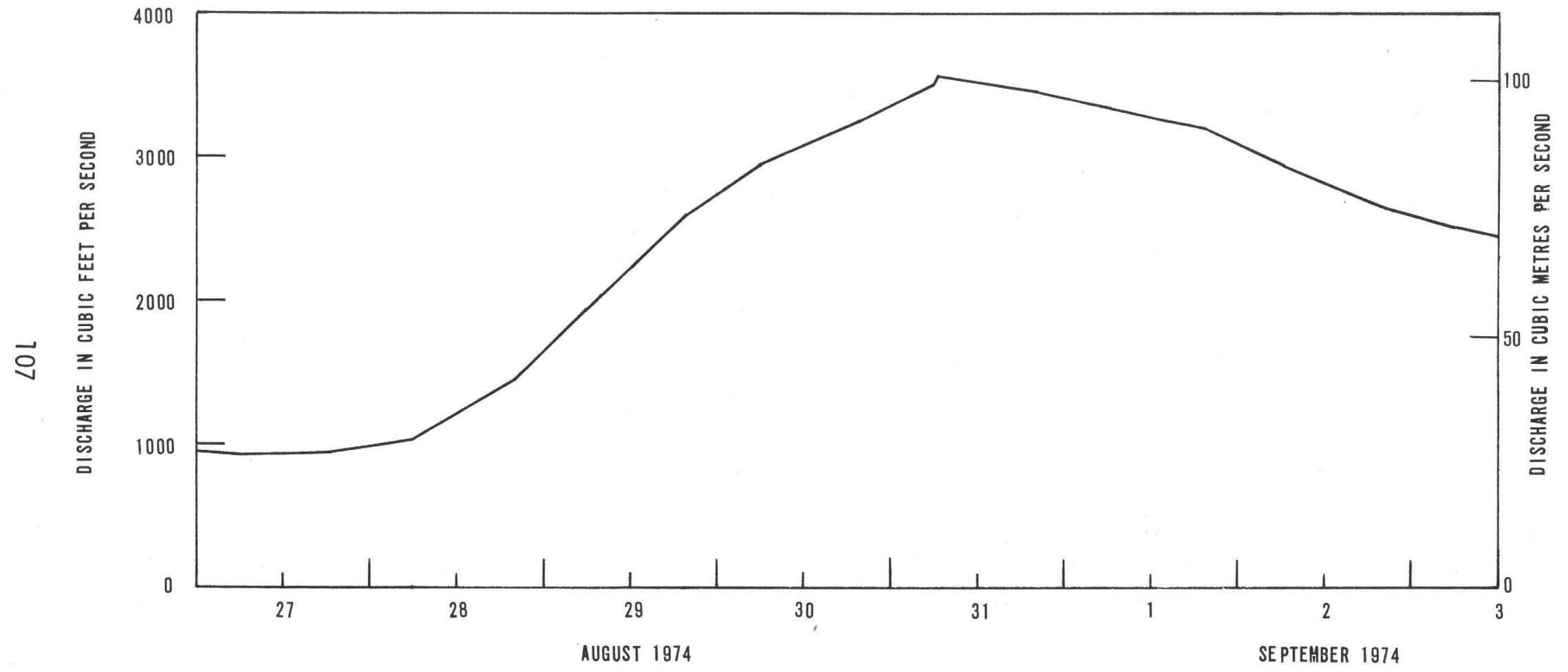

Figure 70.-- Discharge hydrograph for Tonsina River near Tonsina. 


\section{Tiekel River at Tieke1}

Location.--Lat $61^{\circ} 19^{\prime} 12^{\prime \prime}$, long $145^{\circ} 18^{\prime} 33^{\prime \prime}$, in NW/1 sec.30, T.6 S., R.1 W., at pipeline crossing, $3.7 \mathrm{mi}(6.0 \mathrm{~km})$ upstream from Tsina River and $0.5 \mathrm{mi}(0.8 \mathrm{~km})$ south of Tiekel. [Valdez (B-4) 1:63,360, U.S. Geological Survey map.]

Channel conditions.--Low-altitude vertical aerial stereophotography (scale 1:2,400) was obtained September 23, 1972, (fig. 71) to document preconstruction topography at the site. Vertical aerial strip photography (scale 1:6,000) taken August 31, 1974, (fig. 72) shows no significant channel erosion or construction activities have occurred in the crossing reach since September 23, 1972. Three cross sections (fig. 73) were surveyed May 13, 1973, to define preconstruction ground profiles in the crossing reach. On August 1974, a channel survey of the three cross sections found no significant lateral erosion.

Floods.--No significant overbank flooding occurred during the period September 23, 1972, through August 31, 1974. 


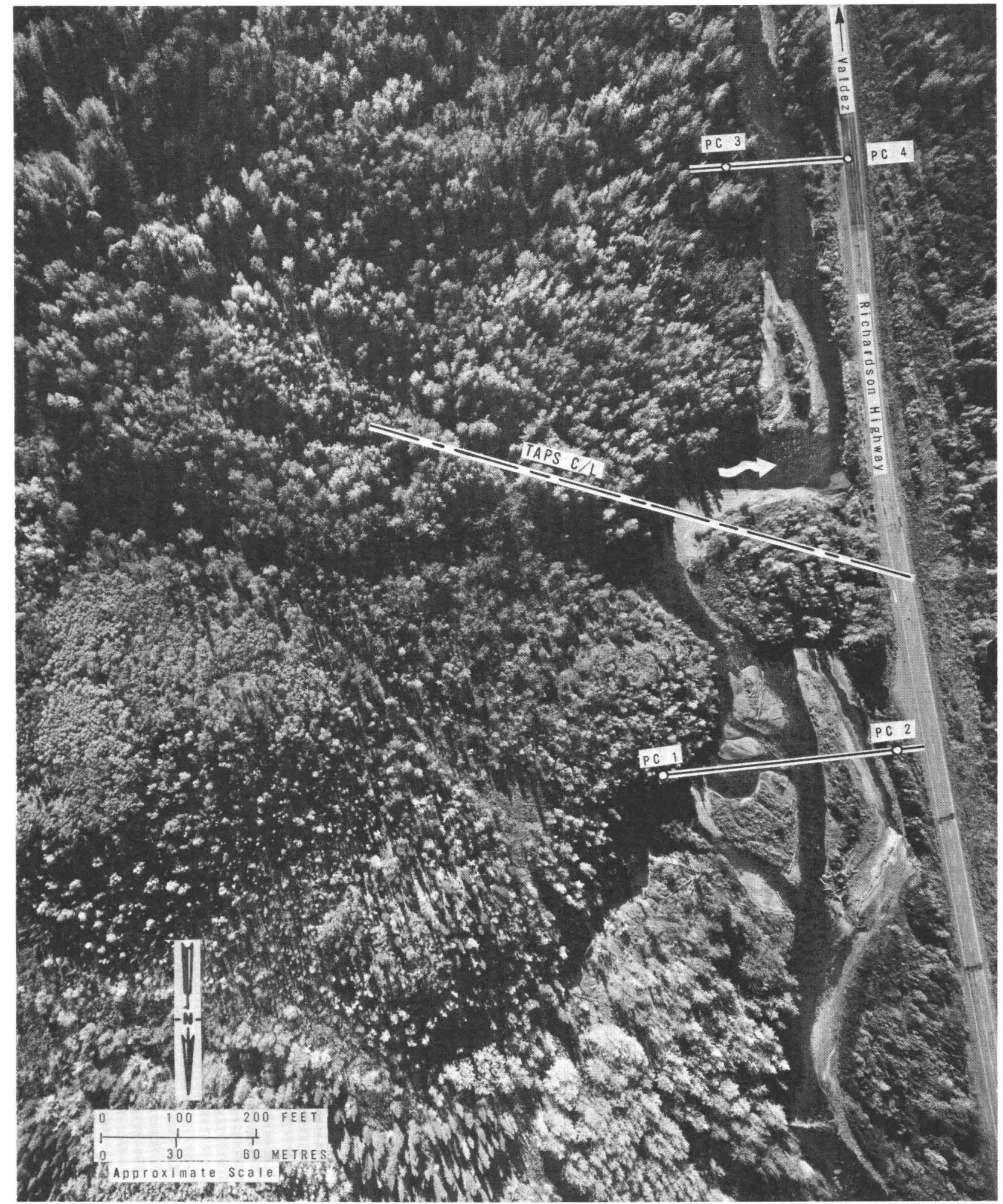

Figure 71. -- Tiekel River at Tiekel, September 23, 1972. NORTH PACIFIC AERIAL SURVEYS 


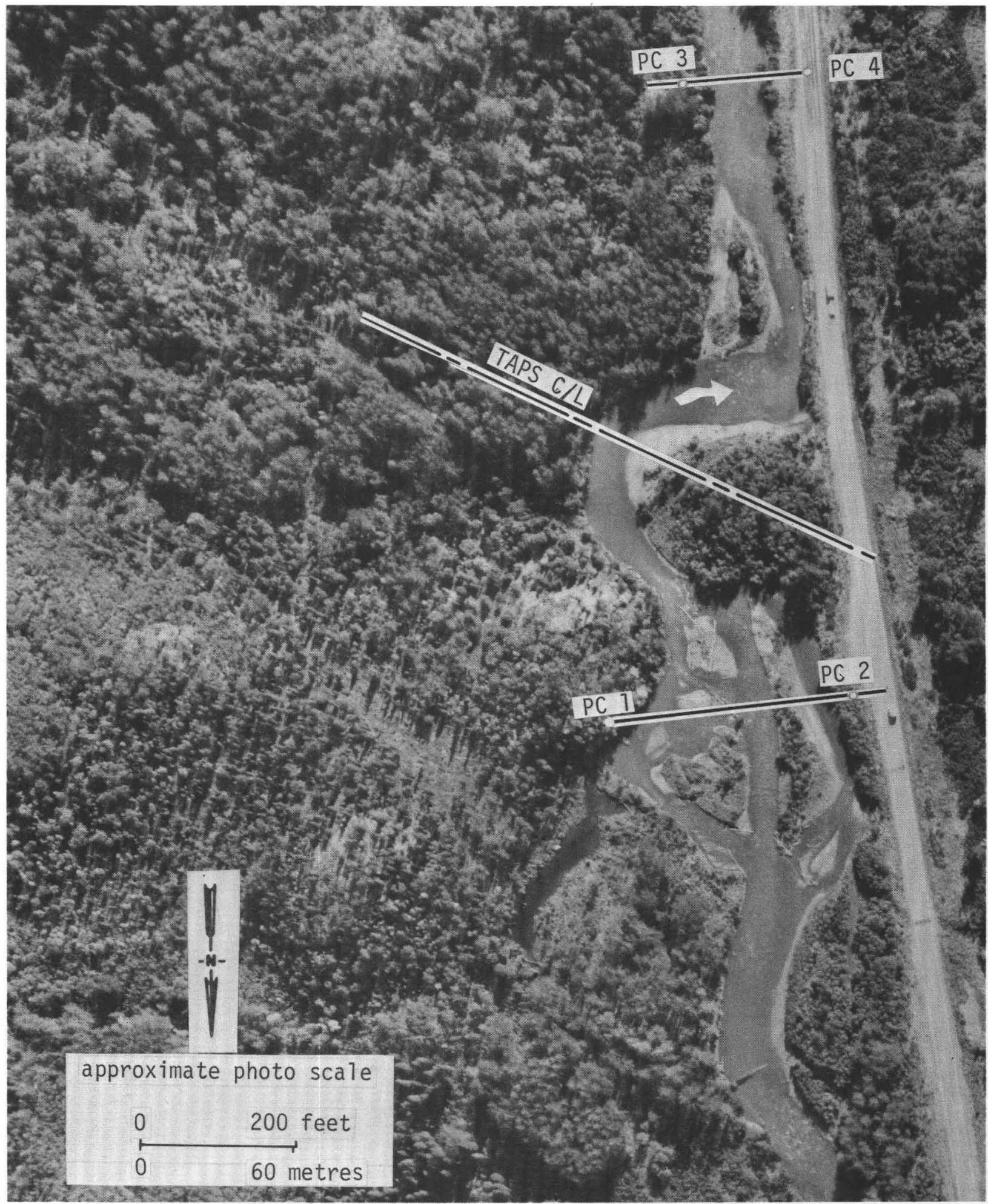

Figure 72. -- Tiekel River at Tiekel, August 31, 1974. ALYESKA PIPELINE SERVICE CO.-AIR PHOTO TECH. 


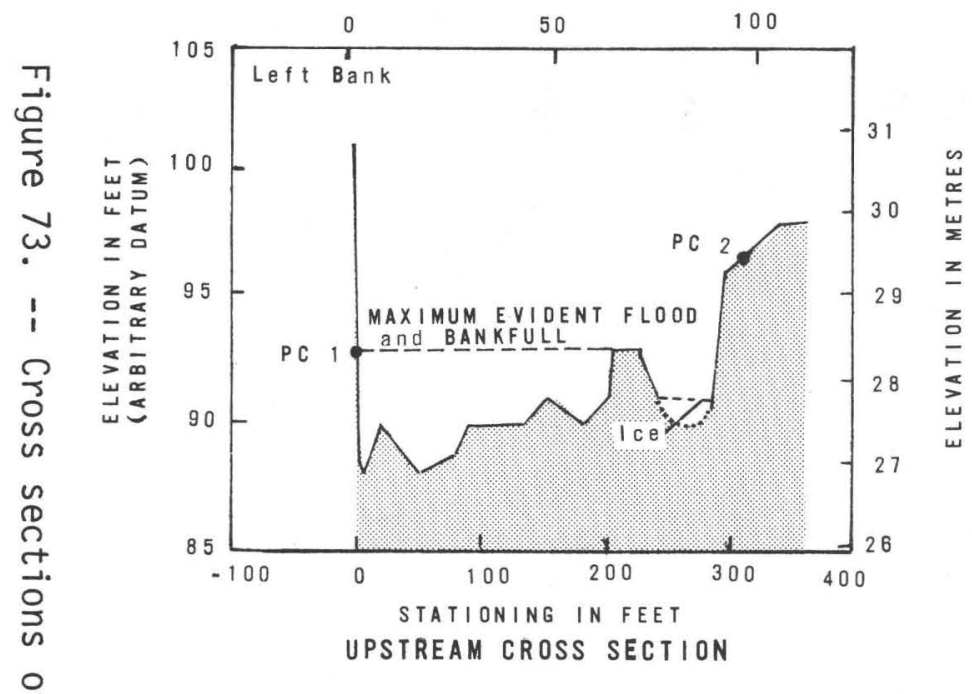

$\frac{1}{9}$

तD

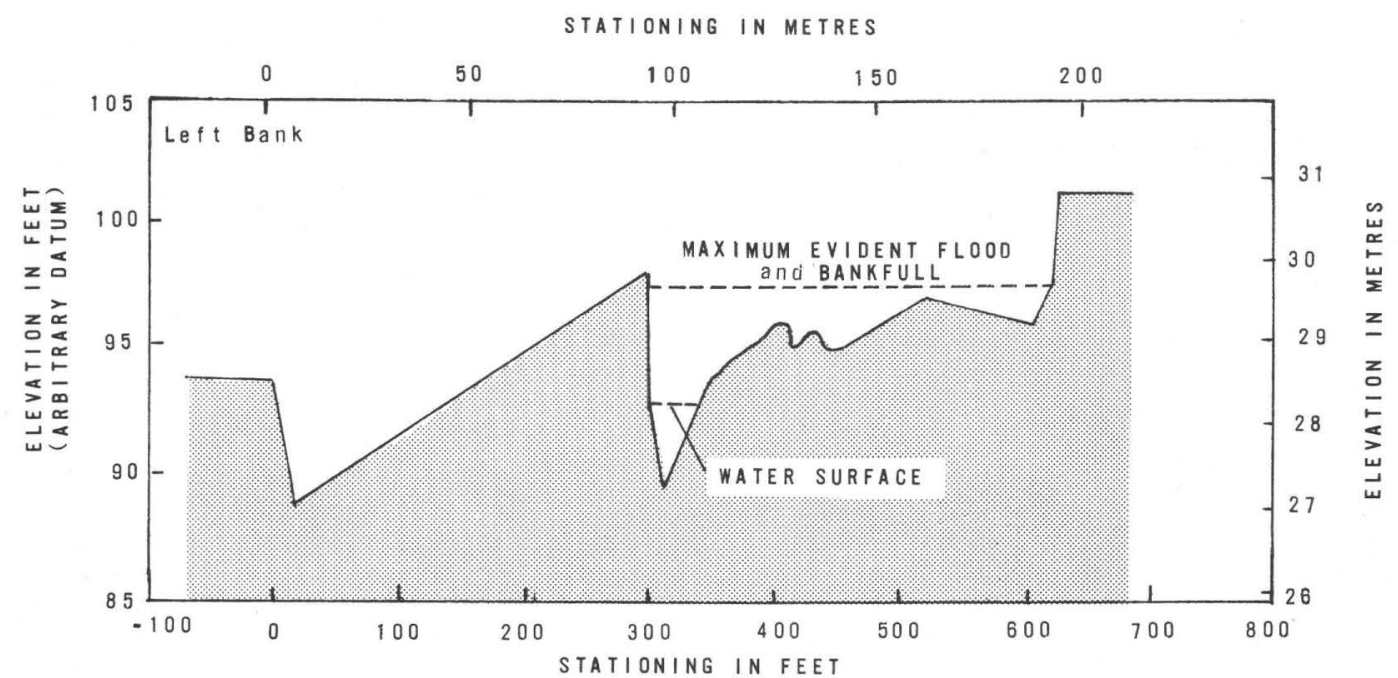

TAPS CENTERLINE CROSS SECTION

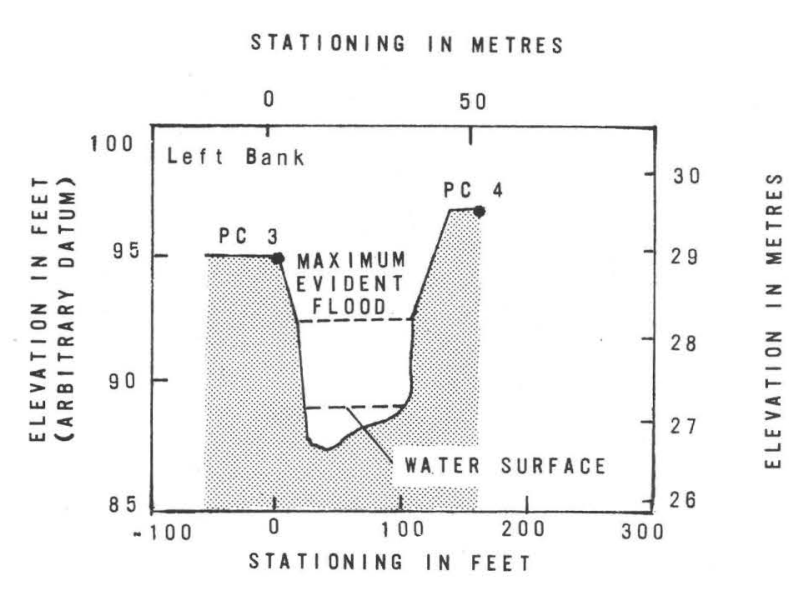

Figure 73. -- Cross sections of the Tiekel River at Tiekel, Alaska, May 13, 1973. 
Location.--Lat $61^{\circ} 16^{\prime} 36^{\prime \prime}$, long $145^{\circ} 16^{\prime} 21^{\prime \prime}$, in NW/ $\frac{1}{4} \mathrm{sec} .8$, T.7 S., R.1 E., at pipeline crossing, $1 \mathrm{mi}(2 \mathrm{~km})$ upstream from Tsina River, and $3.6 \mathrm{mi}(5.8 \mathrm{~km})$ southeast of Tiekel. [Valdez (B-4) 1:63,360, U.S. Geological Survey map.]

Channel conditions.--Low-altitude vertical aerial stereophotography (scale 1:2,400) was obtained September 23, 1972, (fig. 74) to document preconstruction topography at the site. Vertical aerial strip photography (scale 1:6,000) taken August 31, 1974, (fig. 75) shows no significant channel erosion or construction activities have occurred in the crossing reach since September 23, 1972. Three cross sections (fig. 76) were surveyed May 19, 1973, to define preconstruction ground profiles in the crossing reach. On August 1974, a channel survey of the three cross sections found no significant lateral erosion.

Floods.--No significant overbank flooding occurred during the period September 23, 1972, through August 31, 1974. 


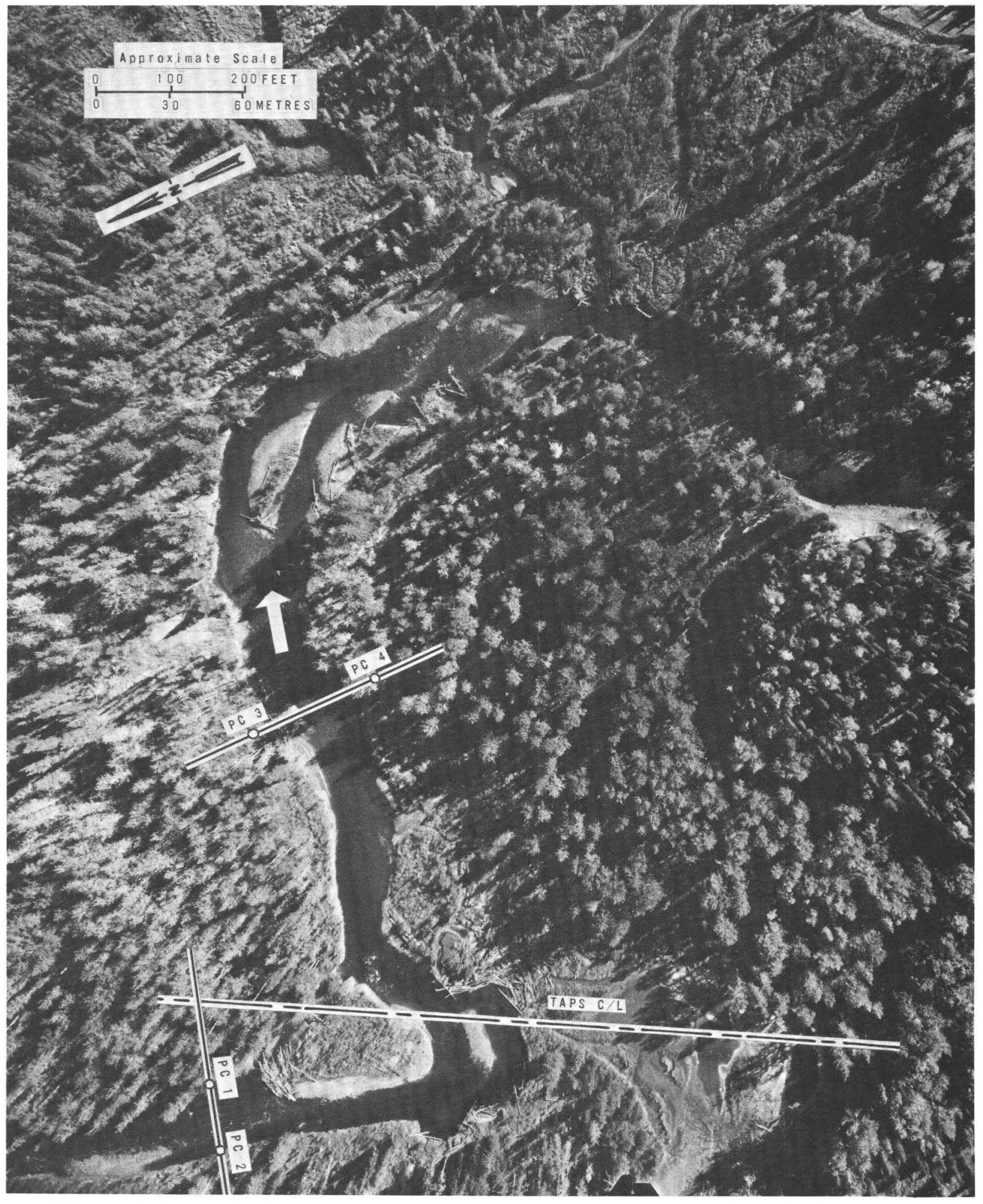

Figure 74. -- Tiekel River near Tiekel, September 23, 1972. NORTH PACIFIC AERIAL SURVEYS 


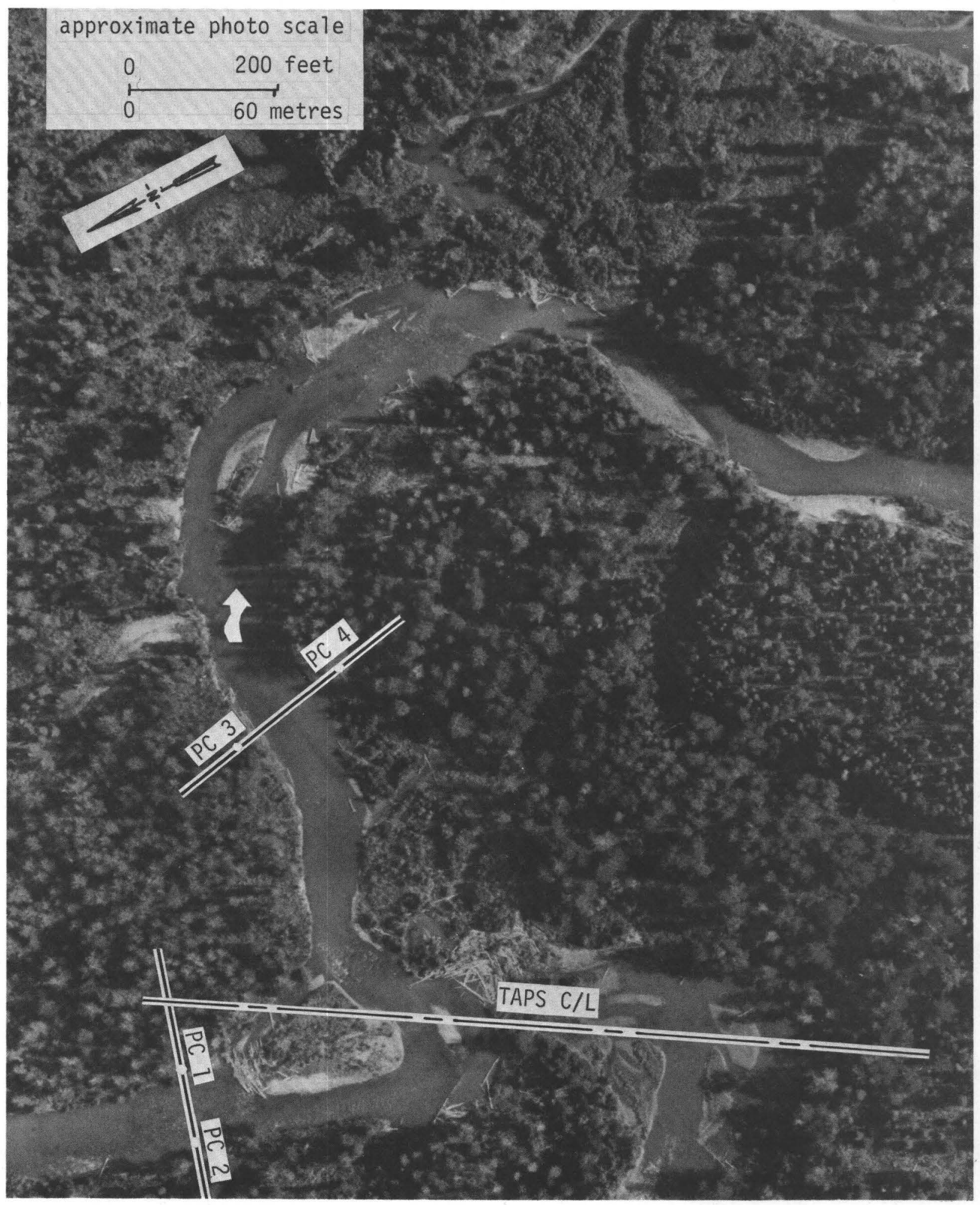

Figure 75. -- Tiekel River near Tieke1, August 31, 1974. ALYESKA PIPELINE SERVICE CO.-AIR PHOTO TECH. 

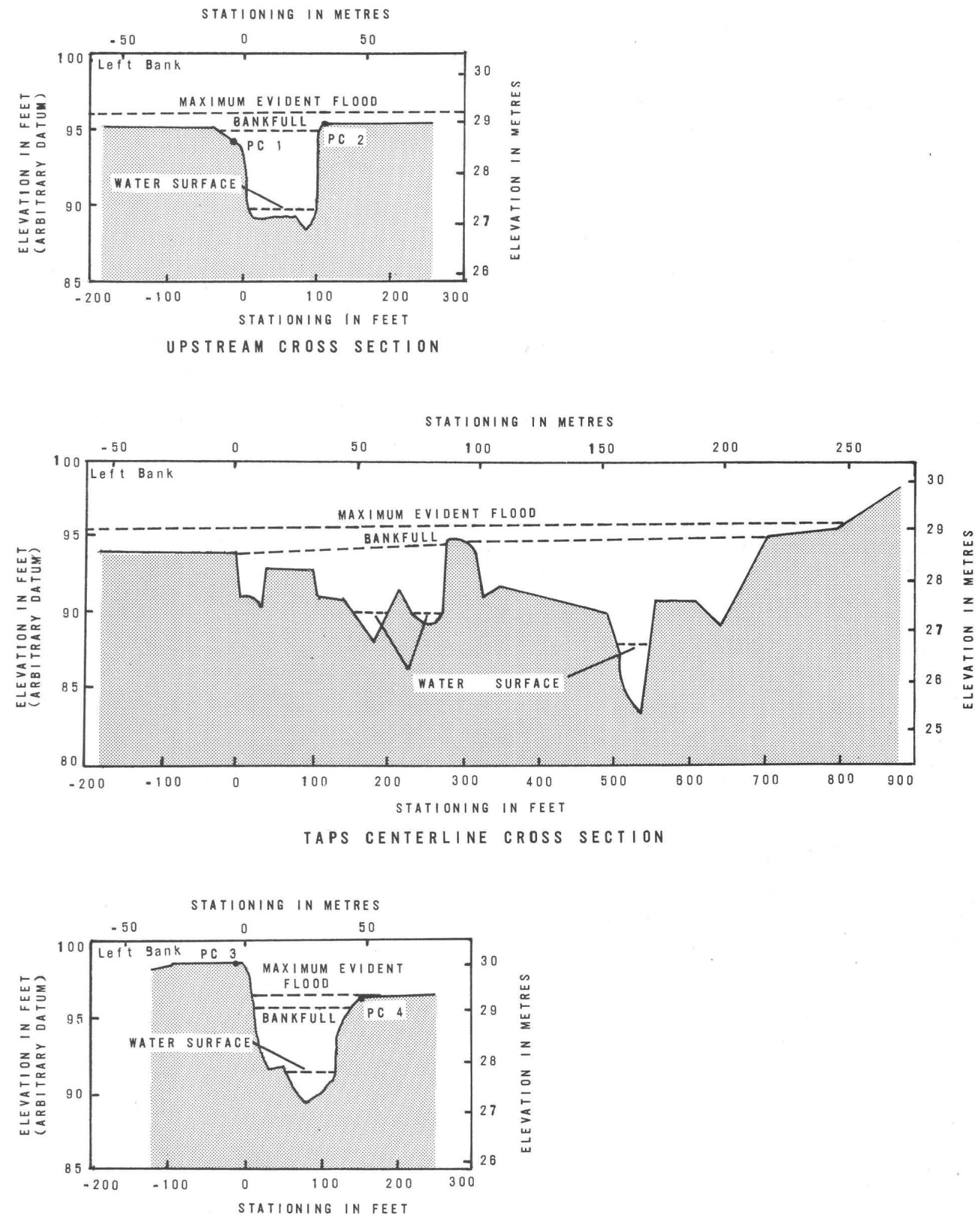

DOWNSTREAM CROSS SECTION

Figure 76. -- Cross sections of the Tiekel River near Tiekel, Alaska, May 19, 1973. 


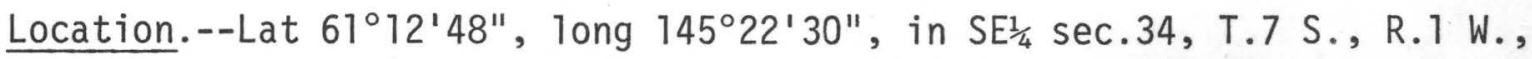
at pipeline crossing, $5.5 \mathrm{mi}(8.8 \mathrm{~km})$ upstream from Tiekel River, and $8 \mathrm{mi}(13 \mathrm{~km})$ southwest of Tiekel. [Valdez (A-4) 1:63,360, U.S. Geological Survey map.]

Channel conditions.--Low-altitude vertical aerial stereophotography (scale 1:2,400) was obtained September 23, 1972, (fig. 77) to document preconstruction topography at the site. Vertical aerial strip photography (scale 1:6,000) taken August 31, 1974, (fig. 78) shows no significant channel erosion or construction activities have occurred in the crossing reach since September 23, 1972. Three cross sections (fig. 79) were surveyed May 17, 1973, to determine preconstruction ground profiles in the crossing reach. On August 1974, a channel survey of the three cross sections found no significant lateral erosion.

Floods.--The maximum flood event for the period of the erosion investigation occurred on August 10, 1974, from Trap Lake's ice-dammed breakout (James Barr, Alaska Pipeline Coordinator's office, oral commun., 1974). A flood peak discharge of $9,800 \mathrm{ft}^{3} / \mathrm{s}\left(278 \mathrm{~m}^{3} / \mathrm{s}\right)$ (table 1) was determined at Tsina River near Ptarmigan, $6 \mathrm{mi}$ $(10 \mathrm{~km})$ upstream from the crossing. This discharge was much less than the maximum evident flood discharge of $20,000 \mathrm{ft}^{3} / \mathrm{s}\left(566 \mathrm{~m}^{3} / \mathrm{s}\right)$ determined at the same site. 


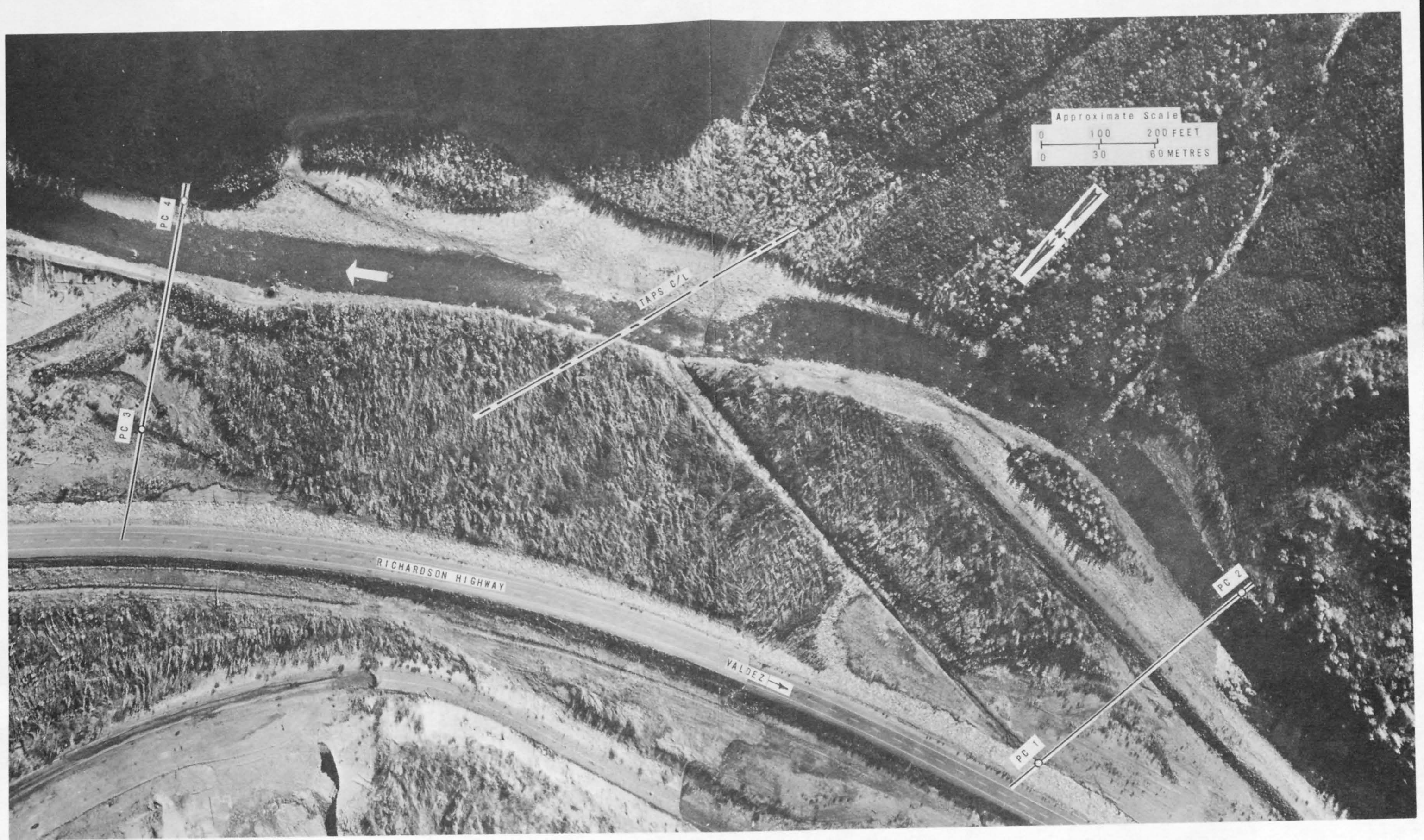

Fiqure 77. -- Tsina River near Tieke1, September 23, 1972. NORTH PACIFIC AERIAL SURVEYS 


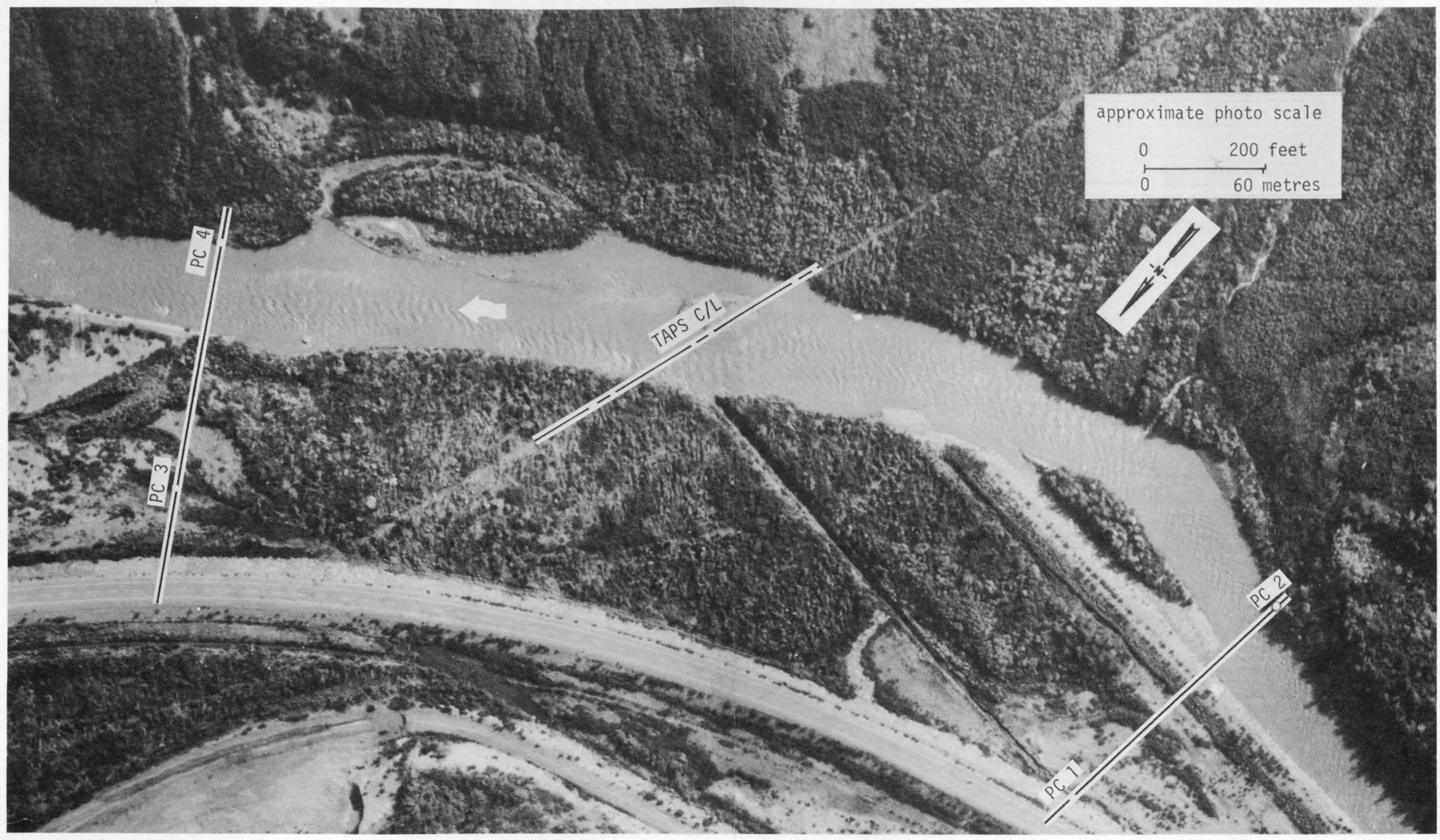

Figure 78. -- Tsina River near Tieke1, August 31, 1974. ALYESKA PIPELINE SERVICE CO.-AIR PHOTO TECH. 


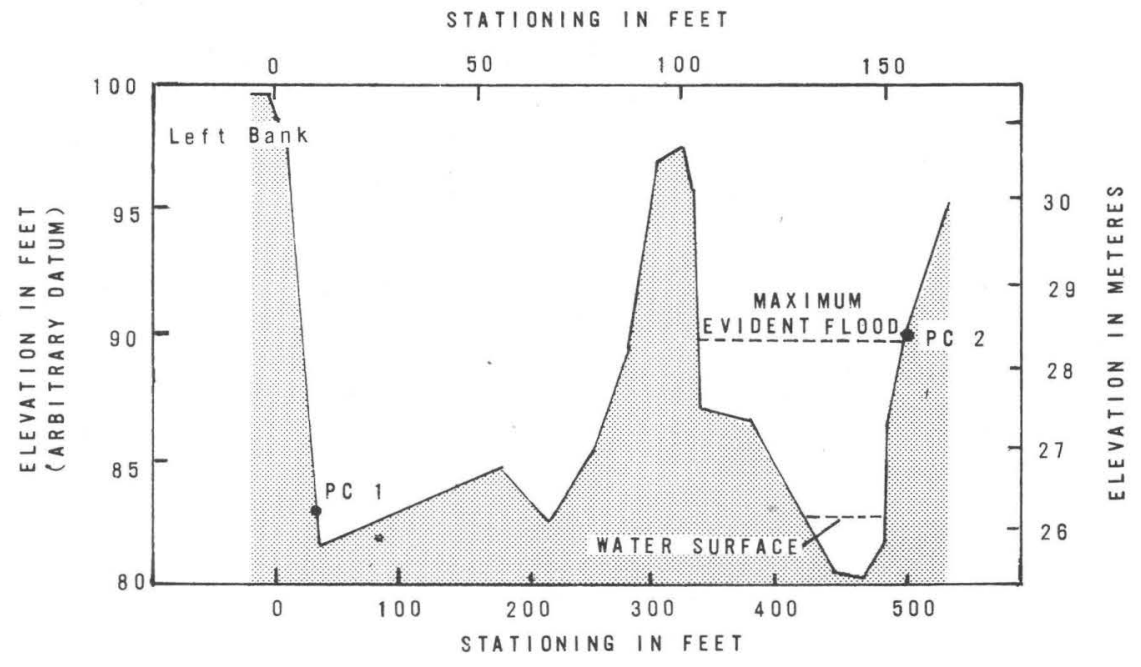

UPSTREAM CROSS SECTION

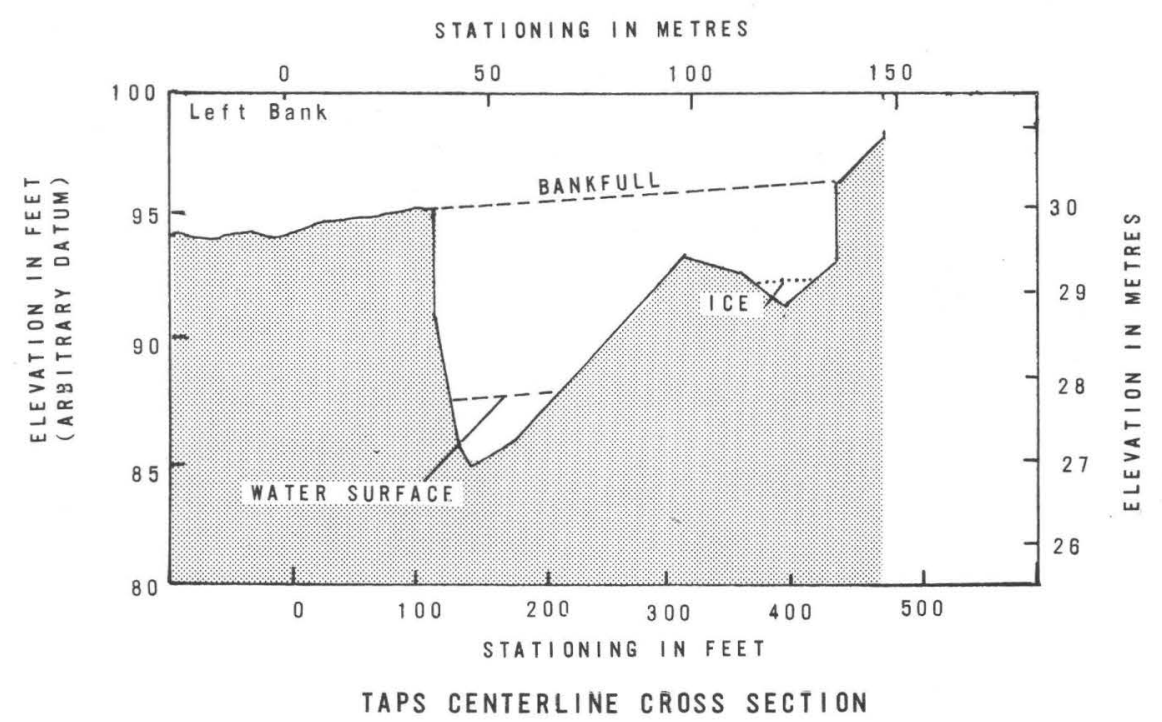

Figure 79.--Cross sections of the Tsina River near Tiekel, Alaska, May 17, 1973. 


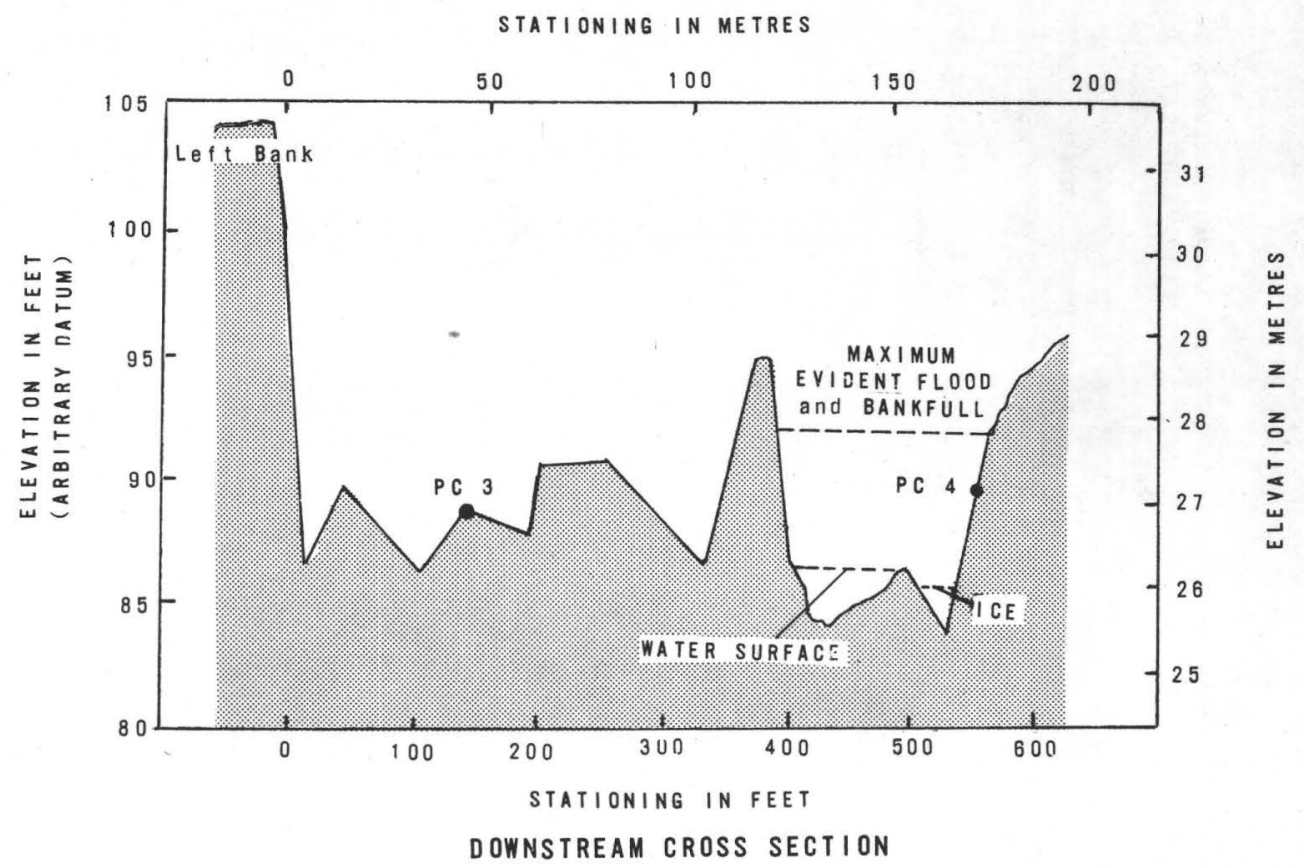

Figure 79.--Cross sections of the Tsina River near Tiekel, Alaska, May 17, 1973--Continued. 


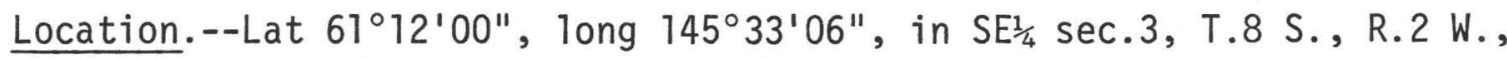
at pipeline crossing, $300 \mathrm{ft}(91 \mathrm{~m})$ downstream from Cascade Creek, and $2.5 \mathrm{mi}(4 \mathrm{~km})$ east of Ptarmigan.

[Valdez (A-5) 1:63,360, U.S. Geological Survey map.]

Channel conditions.--Low-altitude vertical aerial stereophotography (scale 1:2,400) was obtained September 23, 1972, (fig. 80) to document preconstruction topography at the site. Vertical aerial strip photography (scale 1:6,000) taken August 31, 1974, (fig. 81) shows no significant channel erosion or construction activities have occurred in the crossing reach since September 23, 1972. Three cross sections (fig. 82) were surveyed May 17, 1973, to define preconstruction ground profiles in the crossing reach. On August 17, 1974, a channel survey of the three cross sections found no significant lateral erosion.

Floods.--The maximum flood event for the period of the erosion investigation occurred on August 10, 1974, from Trap Lake's ice-dammed breakout (James Barr, Alaska Pipeline Coordinator's office, oral commun., 1974). A flood peak discharge of $9,800 \mathrm{ft}^{3} / \mathrm{s}\left(278 \mathrm{~m}^{3} / \mathrm{s}\right)$ (table 1) was determined at this site. This discharge is much less than the maximum evident flood discharge of $20,000 \mathrm{ft}^{3} / \mathrm{s}$ $\left(566 \mathrm{~m}^{3} / \mathrm{s}\right)$. 


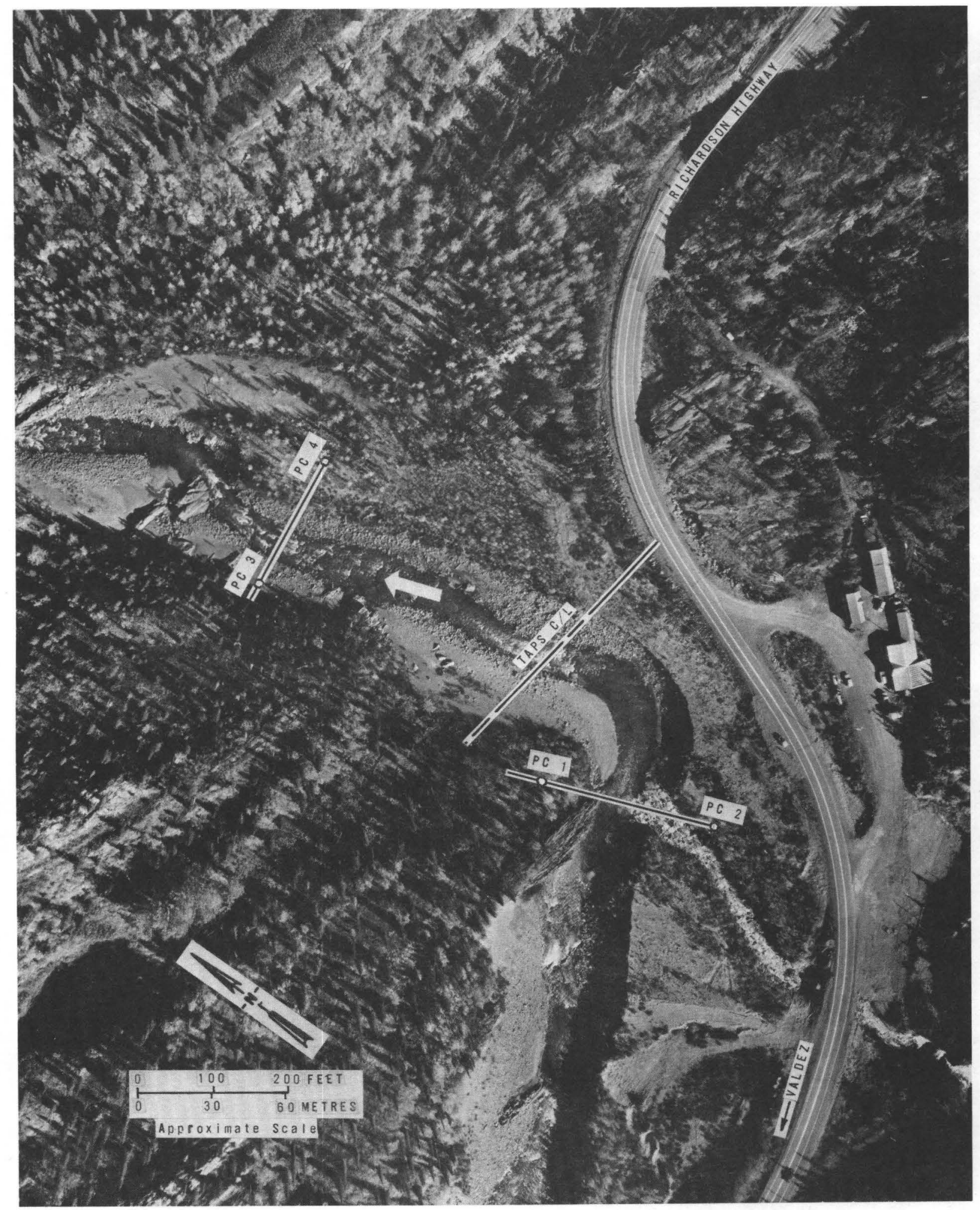

Figure 80. -- Tsina River near Ptarmigan, September 23, 1972. NORTH PACIFIC AERIAL SURVEYS 


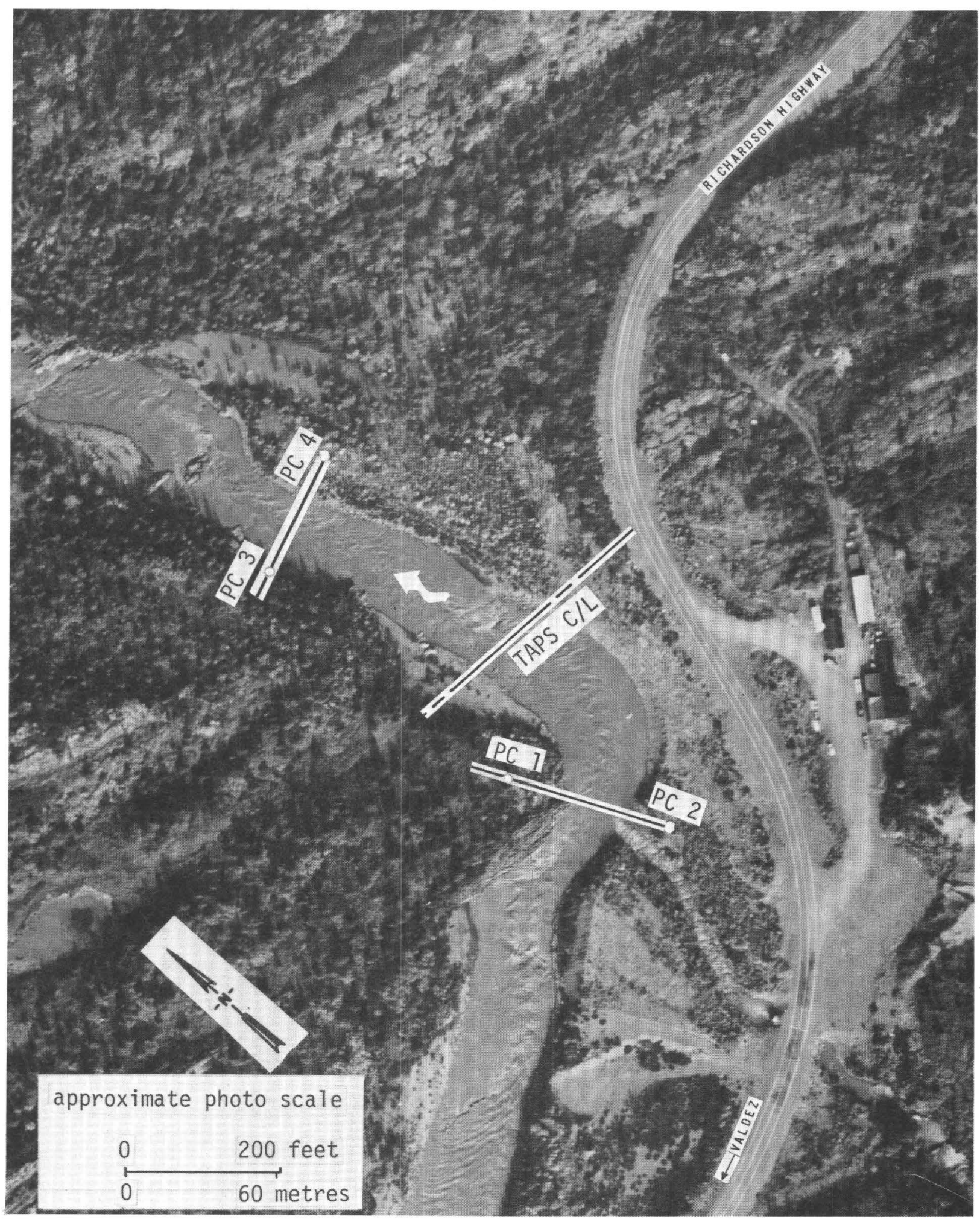

Figure 81. -- Tsina River near Ptarmigan, August 31, 1974. ALYESKA PIPELINE SERVICE CO.-AIR PHOTO TECH. 


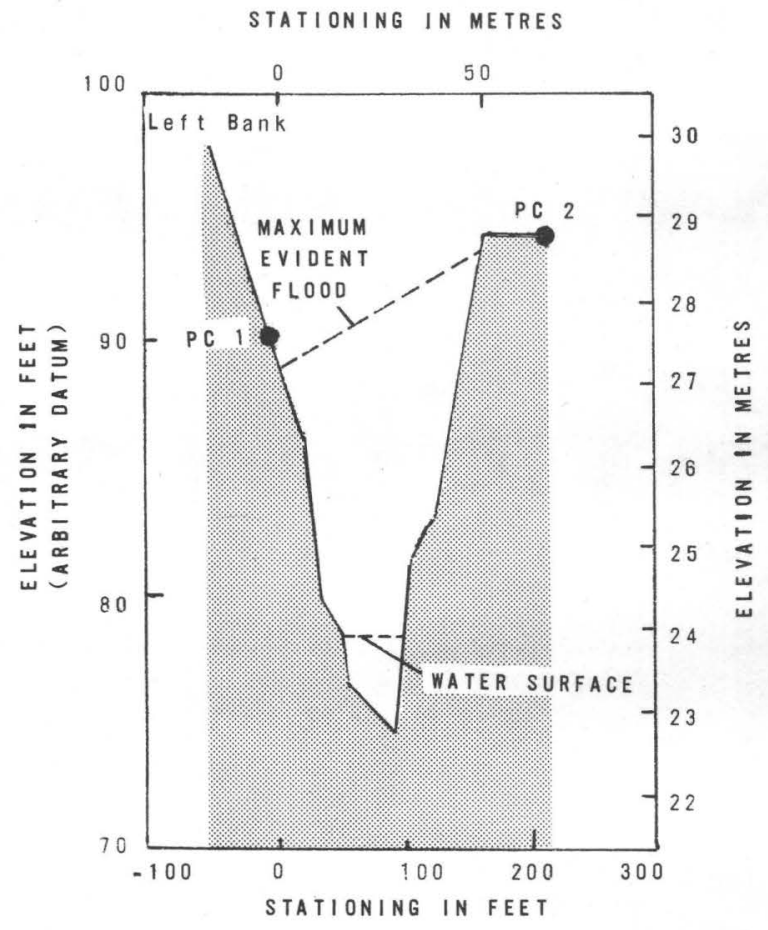

UPSTREAM CROSS SECTION

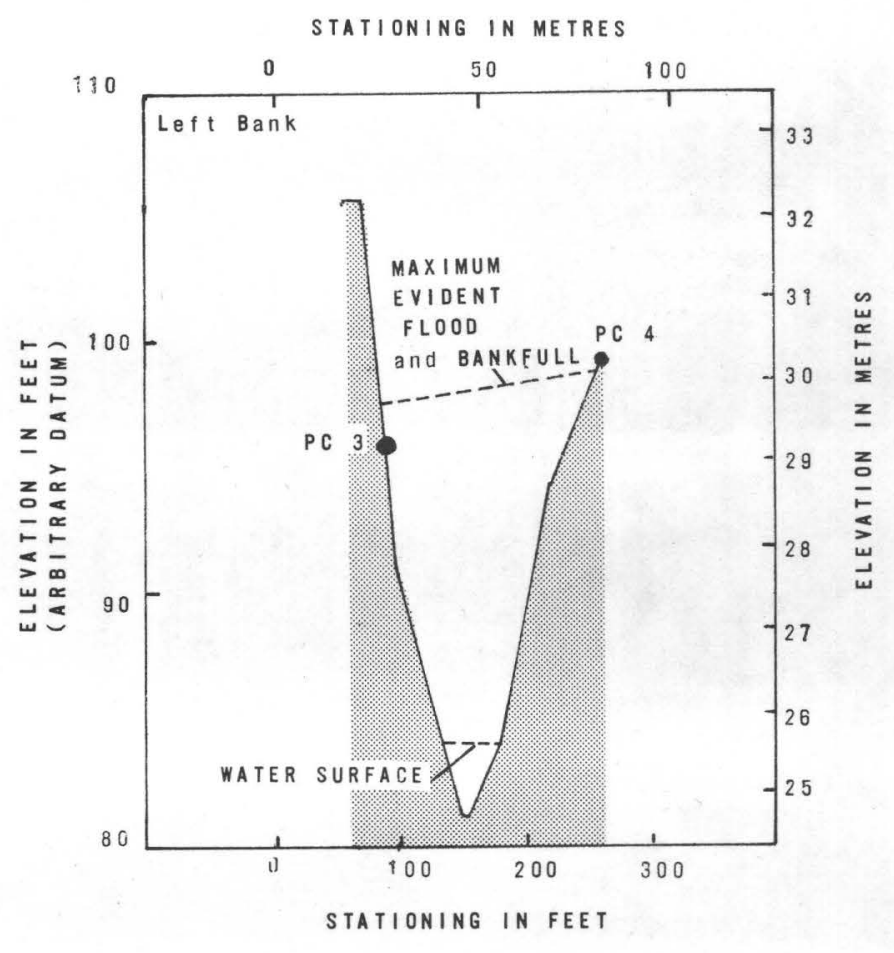

DOWNSTREAM CROSS SECTION

Figure 82.--Cross sections of the Tsina River near Ptarmigan, Alaska, May 17, 1973. 


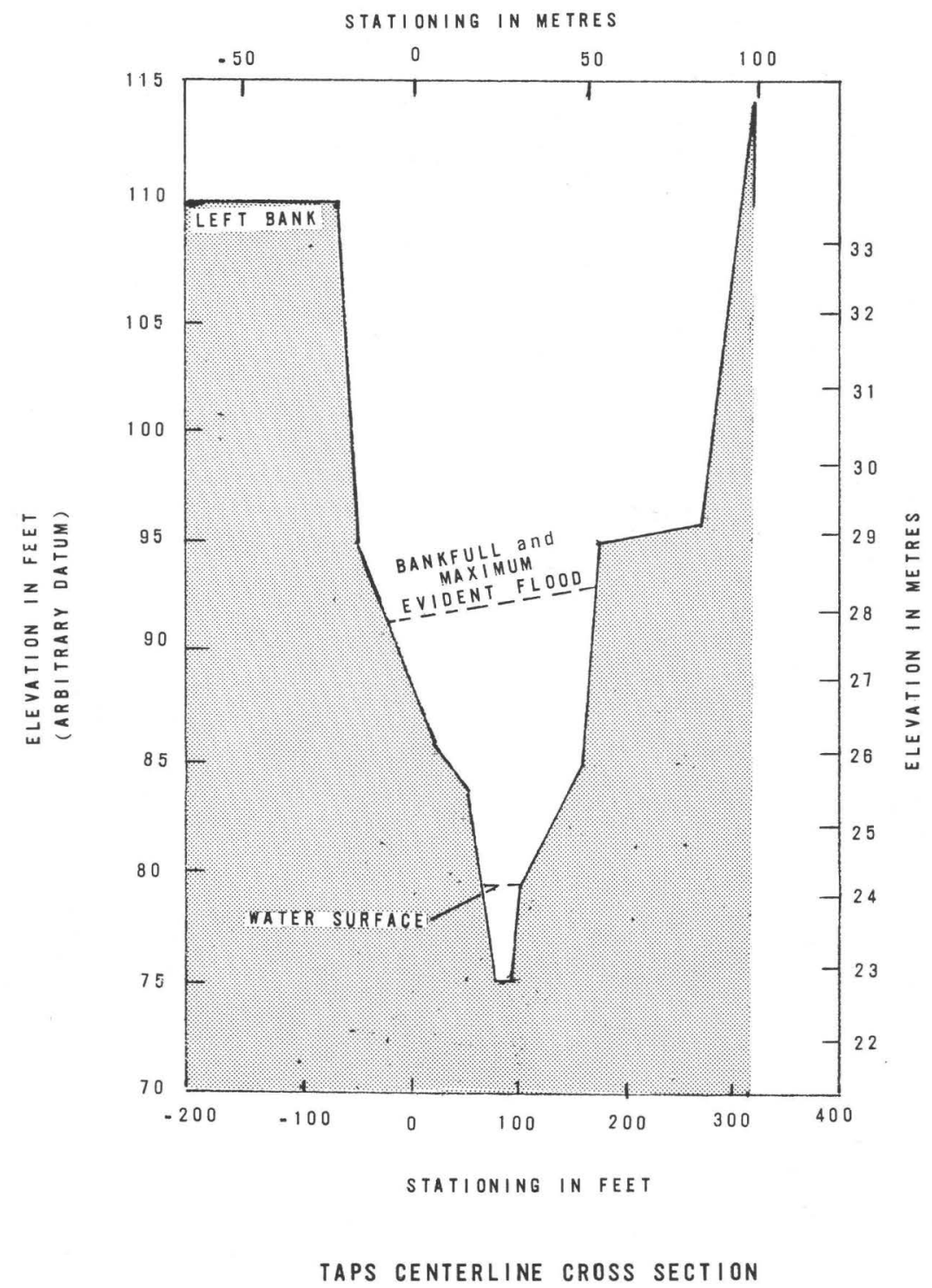

Figure 82.-- Cross sections of the Tsina River near Ptarmigan, Alaska, May 17, 1973--Continued. 
Location.--Lat $61^{\circ} 11^{\prime} 40^{\prime \prime}$, long $145^{\circ} 39^{\prime} 10^{\prime \prime}$, in NE⿺ $\frac{1}{4} \mathrm{sec} .7$, T.8 S., R.2 W., at pipeline crossing at Ptarmigan Creek $1 \mathrm{mi}(2 \mathrm{~km})$ northwest of Ptarmigan.

[Valdez (A-5) 1:63,360, U.S. Geological Survey map.]

Channel conditions.--Low-altitude vertical aerial stereophotography (scale 1:6,000) was obtained September 23, 1972, (fig. 83) to document preconstruction topography at the site. Vertical aerial strip photography (scale 1:6,000) taken August 31, 1974, (fig. 84) shows the main channel flow has concentrated along the left bank in sections 34600 and 35264 . No significant channel erosion or construction activities have occurred since September 23, 1972. The six cross sections shown in figure 85 were surveyed by Alyeska Pipeline Service Company to define preconstruction ground profiles for the purpose of pipeline design.

Floods.--The maximum flood event for the period of the erosion investigation occurred on August 10, 1974, from Trap Lake's ice-dammed breakout (James Barr, Alaska Pipeline Coordinator's office, oral commun., 1974). A floodpeak discharge of $9,800 \mathrm{ft}^{3} / \mathrm{s}\left(278 \mathrm{~m}^{3} / \mathrm{s}\right)$ (table 1) was determined at Tsina River near Ptarmigan $3 \mathrm{mi}(5 \mathrm{~km})$ downstream from the crossing. This discharge was much less than the maximum evident flood discharge of $20,000 \mathrm{ft}^{3} / \mathrm{s}\left(566 \mathrm{~m}^{3} / \mathrm{s}\right)$ determined at the same site. 


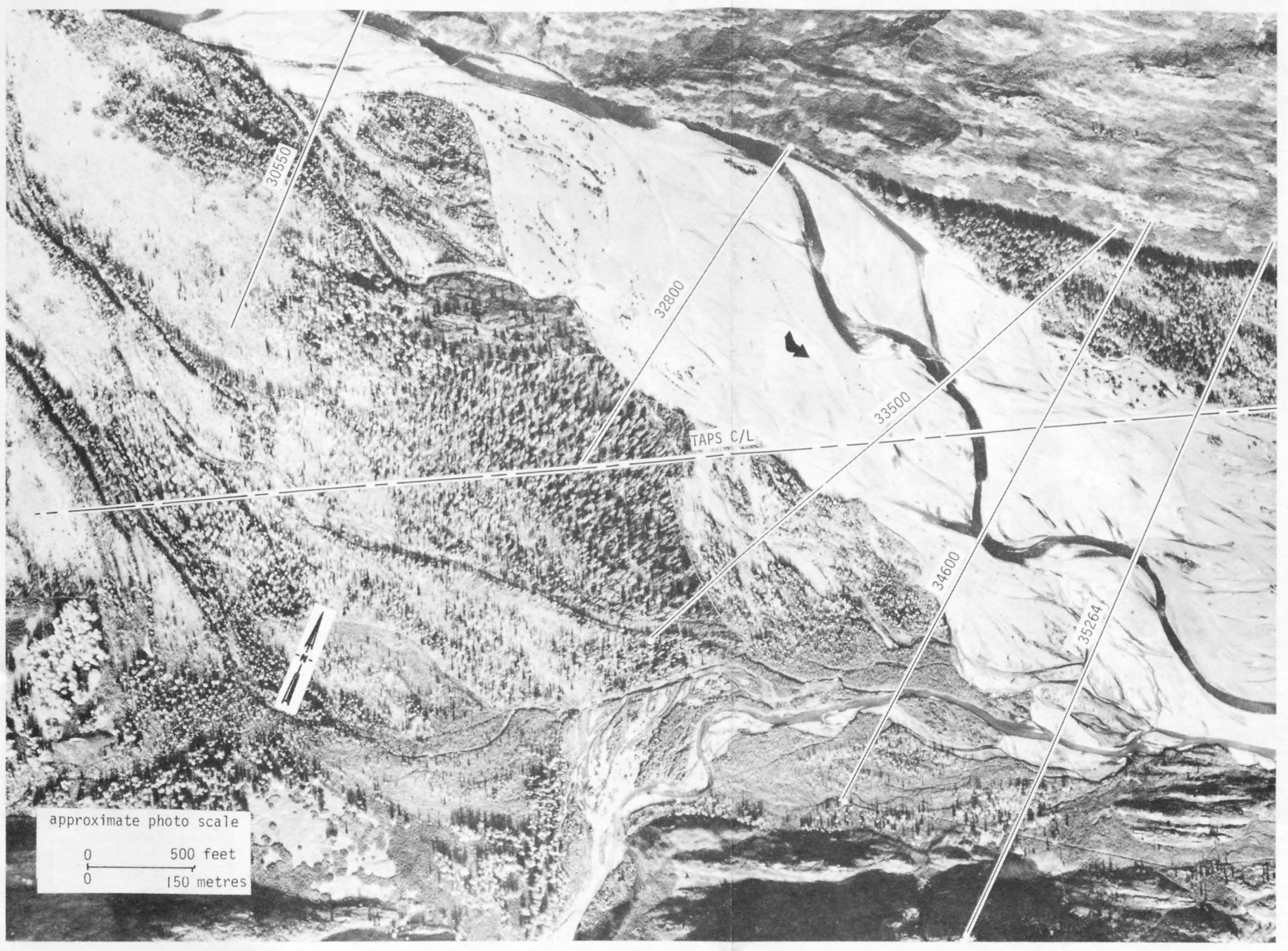

Figure 83. -- Tsina River at Ptarmigan, September 23, 1972. TOBIN RESEARCH INC. 


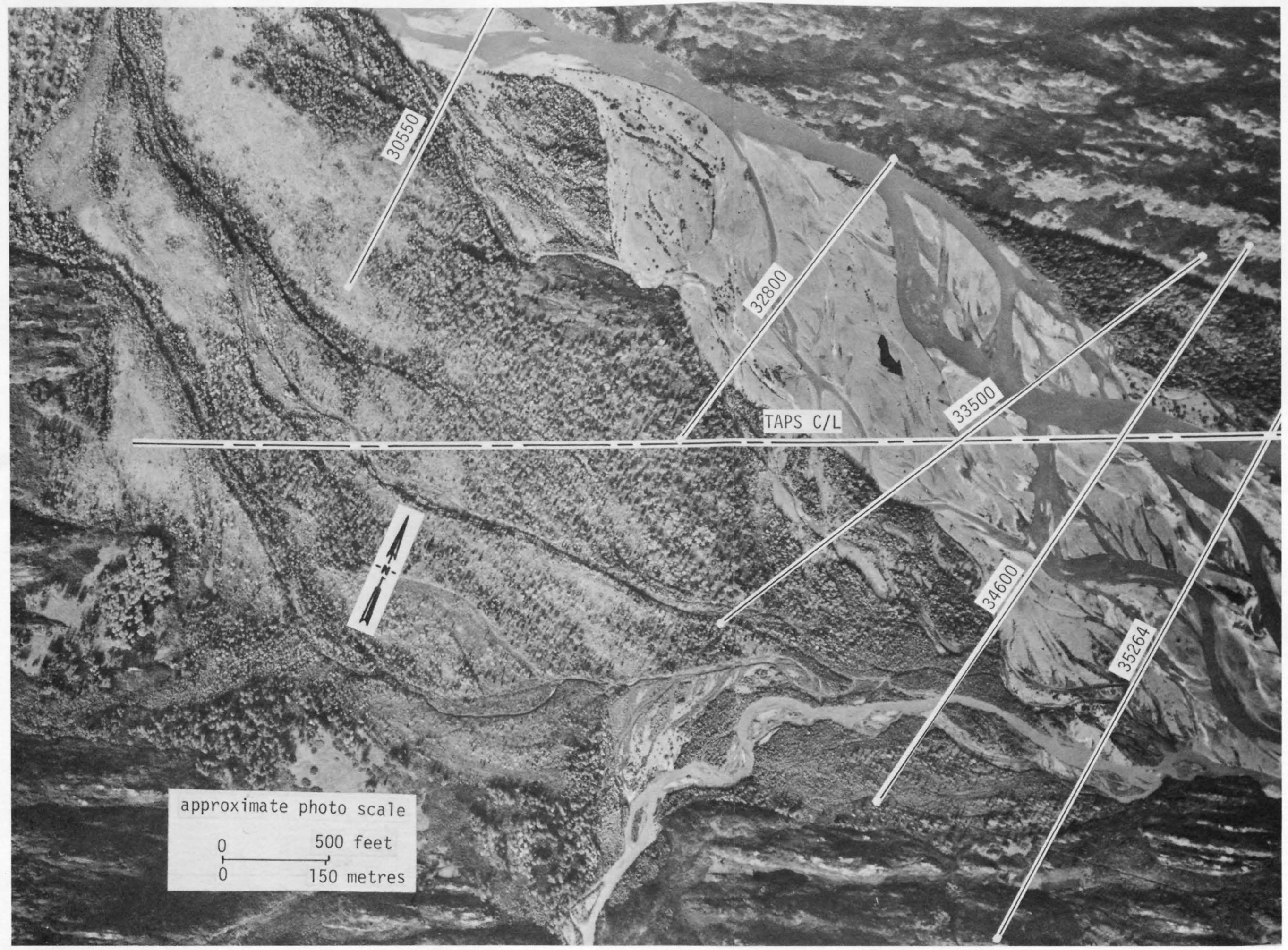

Figure 84. -- Tsina River at Ptarmigan, August 31, 1974. ALYESKA PIPELINE SERVICE CO.-AIR PHOTO TECH. 
STATIONING IN METRES

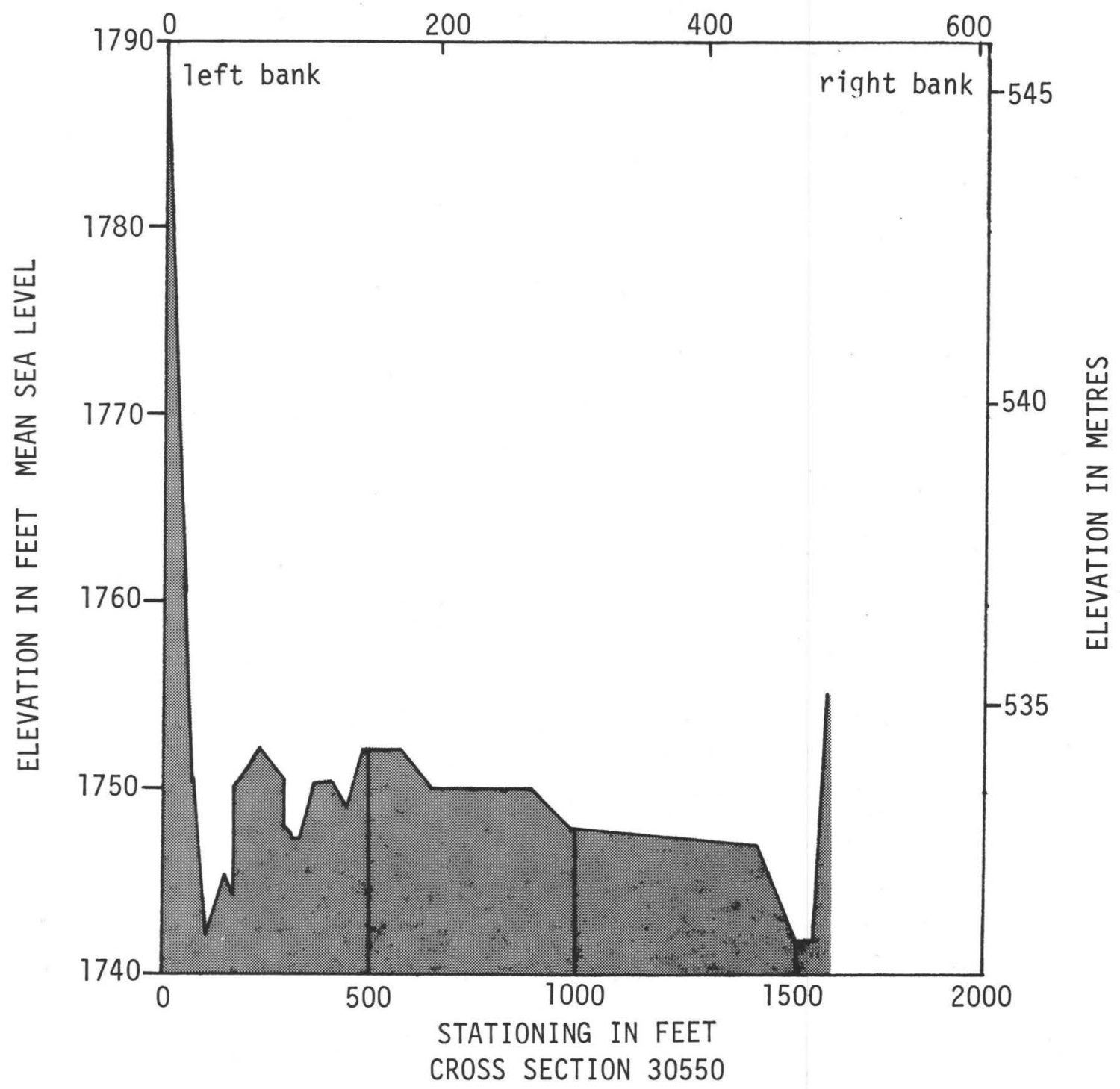

Figure 85. -- Cross sections of the Tsina River at Ptarmigan, July 1973. From Alyeska Pipeline Service Co. Survey. 
STATIONING IN METRES

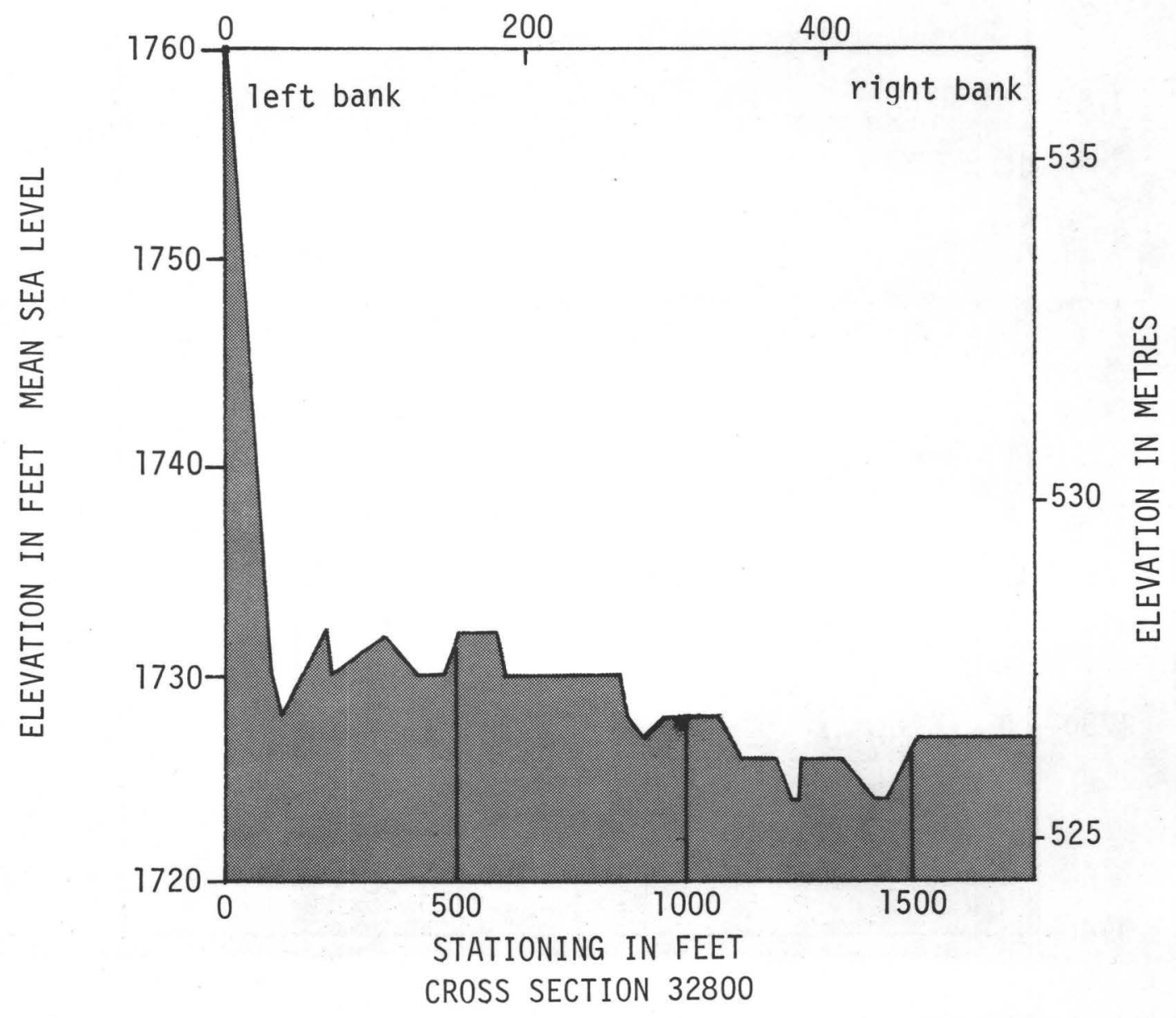

Figure 85. -- Cross sections of the Tsina River at Ptarmigan, July 1973 -Continued. From Alyeska Pipeline Service Co. Survey. 
STATIONING IN METRES

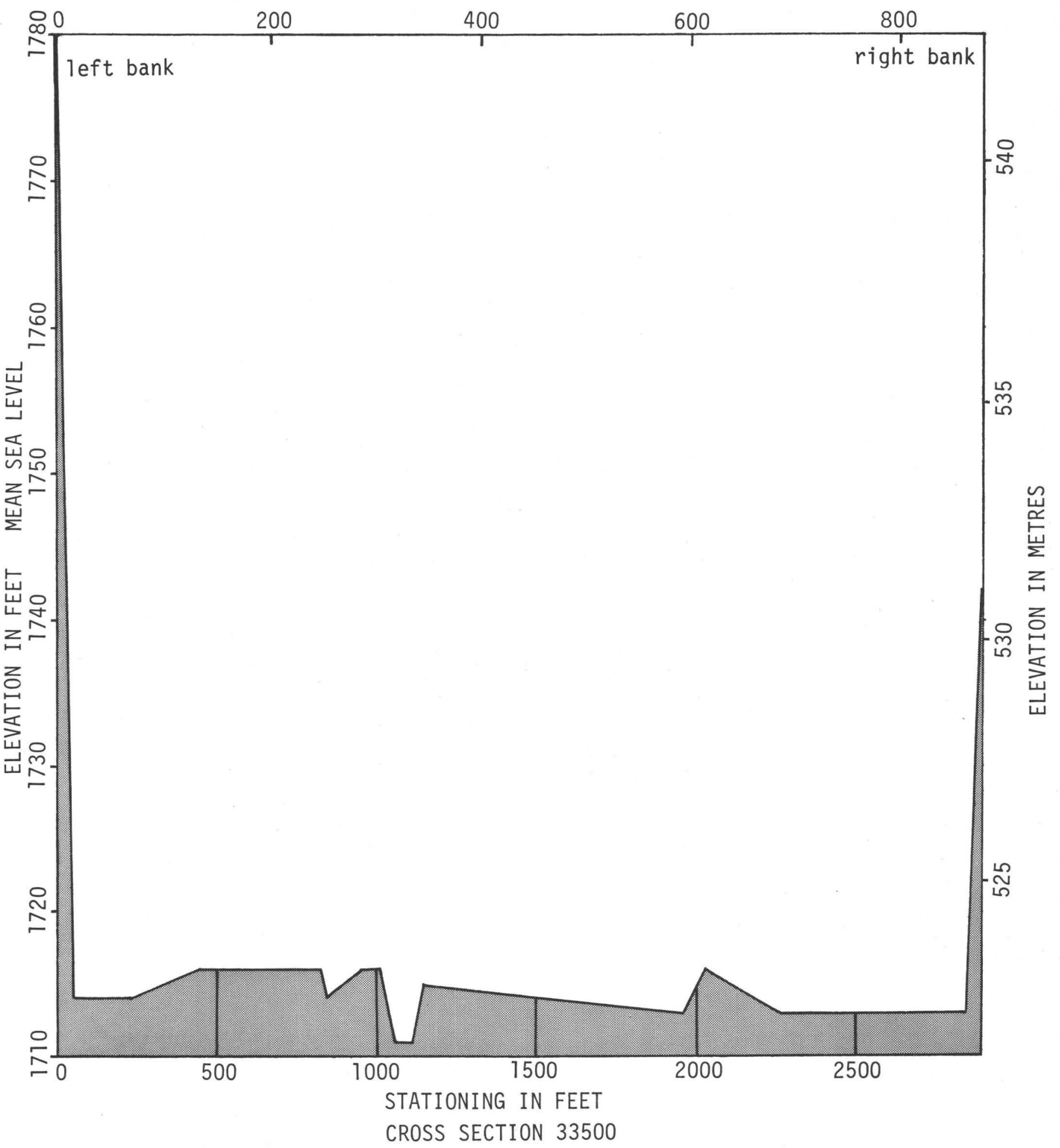

Figure 85. -- Cross sections of the Tsina River at Ptarmigan, July 1973 -Continued. From Alyeska Pipeline Service Co. Survey. 



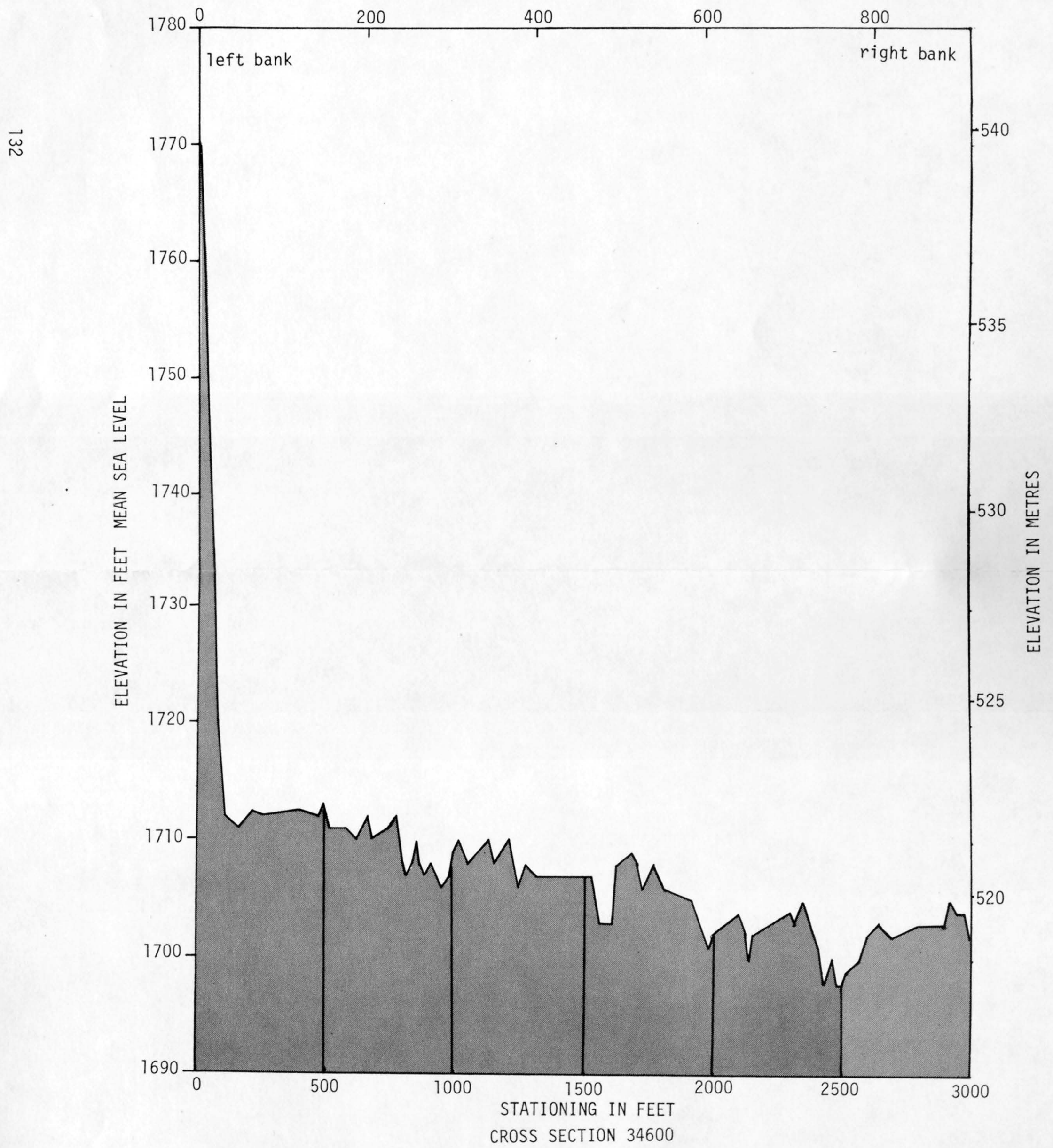

Figure 85. -- Cross sections of the Tsina River at Ptarmigan, July 1973 -- Continued. From Alyeska Pipeline Service Co. Survey. 
Figure 85. -- Cross sections of the Tsina River at Ptarmigan, July 1973 -- Continued. From Alyeska Pipeline Service Co. Survey. 


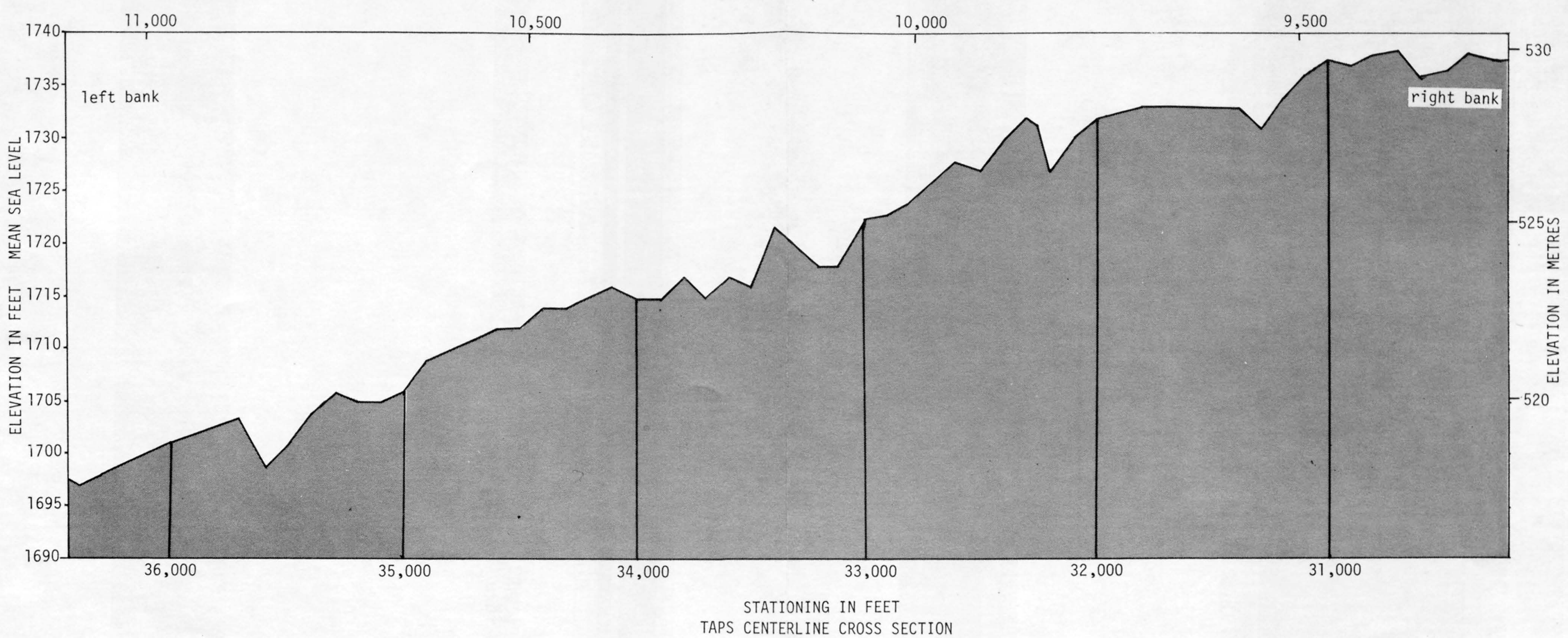

Figure 85. -- Cross sections of the Tsina River at Ptarmigan, July 1973 -- Continued. From Alyeska Pipeline Service Co. Survey. 
Location.--Lat $61^{\circ} 06^{\prime} 30^{\prime \prime}$, long $145^{\circ} 48^{\prime} 30^{\prime \prime}$, in SW/ sec.5, T.9 S., R.3 W., at pipeline crossing, $0.2 \mathrm{mi}(0.3 \mathrm{~km})$ upstream from Lowe River, and $18 \mathrm{mi}(29 \mathrm{~km})$ east of Valdez. [Valdez (A-5) 1:63,360, U.S. Geological Survey map.]

Channel conditions.--Low-altitude vertical aerial stereophotography (scale 1:2,400) was obtained September 23, 1972, (fig. 86) to document preconstruction topography at the site. Vertical aerial strip photography (scale 1:6,000) obtained August 31, 1974, (fig. 87) shows no significant channel erosion or construction activities have occurred in the immediate vicinity of the crossing reach since September 23, 1972. A large removal site is located $800 \mathrm{ft}(240 \mathrm{~m})$ north of the crossing reach. Three cross sections (fig. 88) were surveyed May 19, 1973, to define preconstruction ground profiles in the crossing reach.

Floods.--No significant overbank flooding occurred during the period of erosion investigation September 23, 1972, through August 31, 1974. 


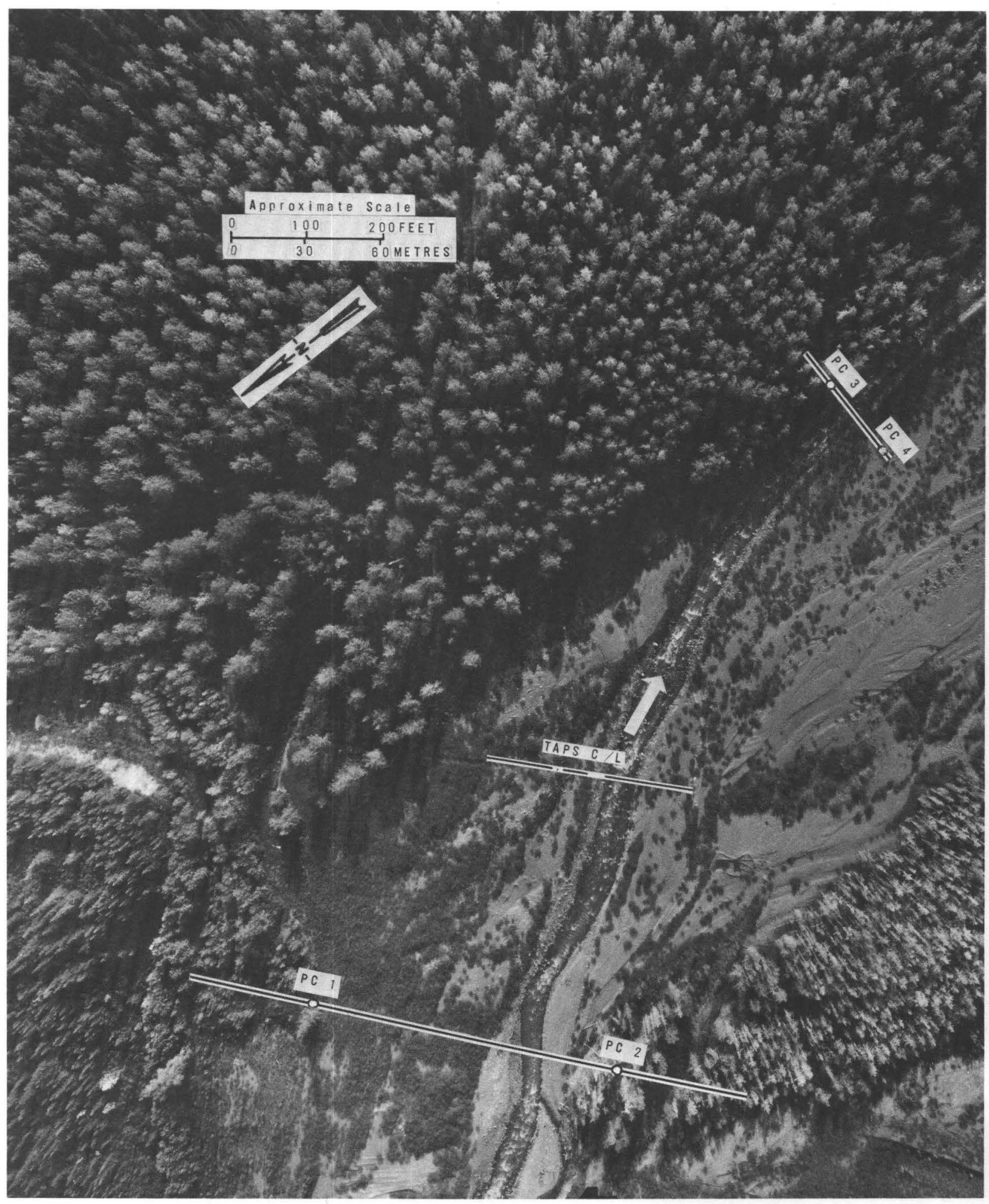

Figure 86. -- Sheep Creek near Valdez, September 23, 1972. NORTH PACIFIC AERIAL SURVEYS 


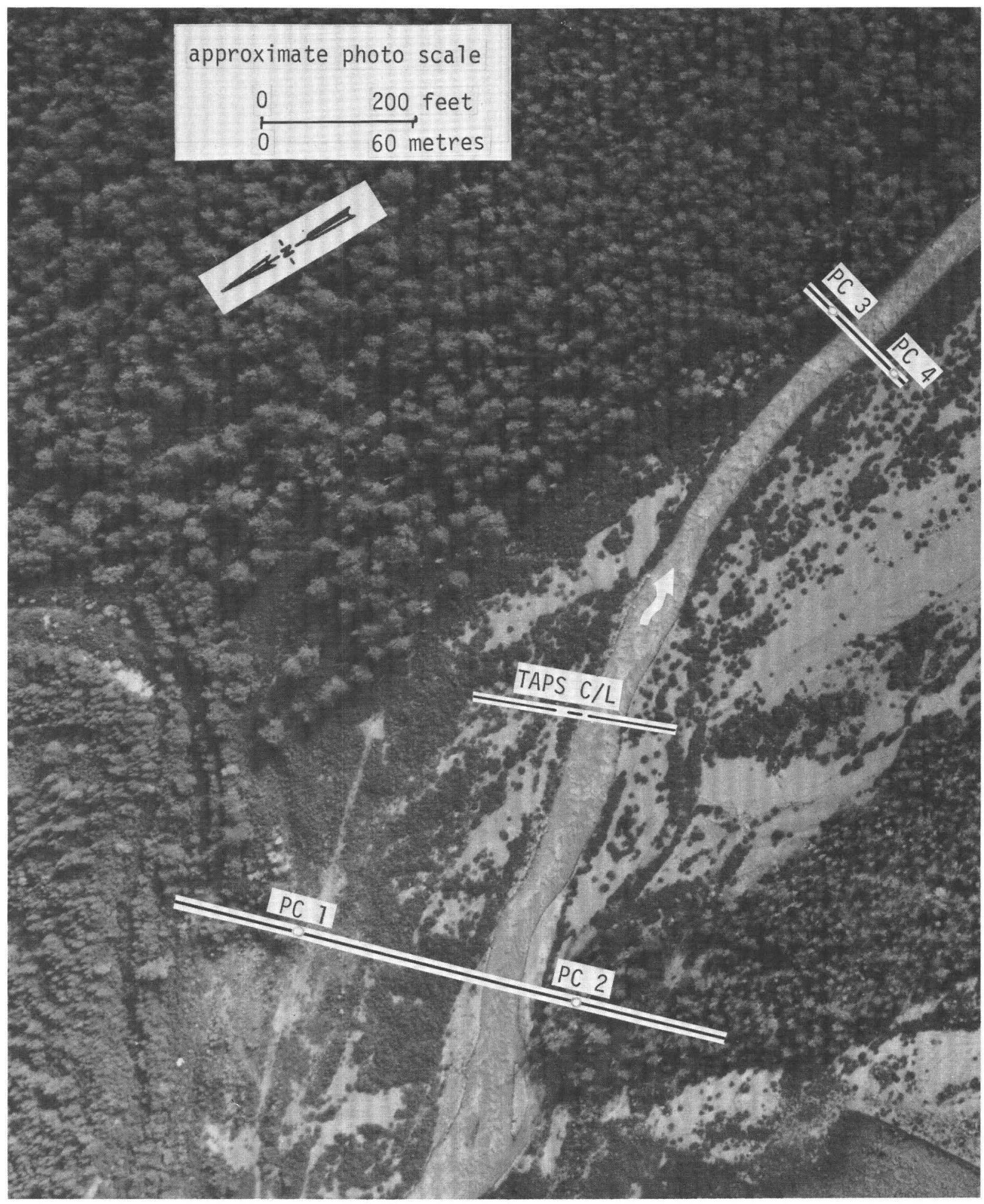

Figure 87. -- Sheep Creek near Valdez, August 31, 1974. ALYESKA PIPELINE SERVICE CO. -AIR PHOTO TECH. 
STATIONING IN METRES

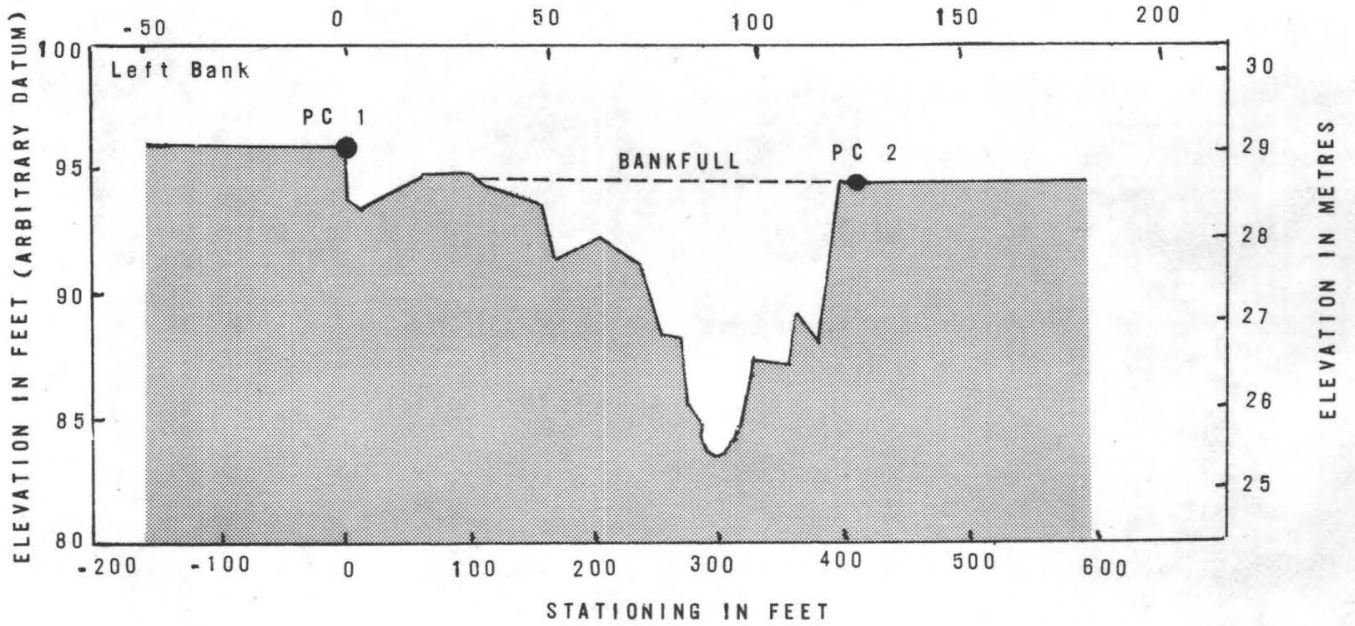

UPSTREAM CROSS SECTION

STATIONING IN METRES

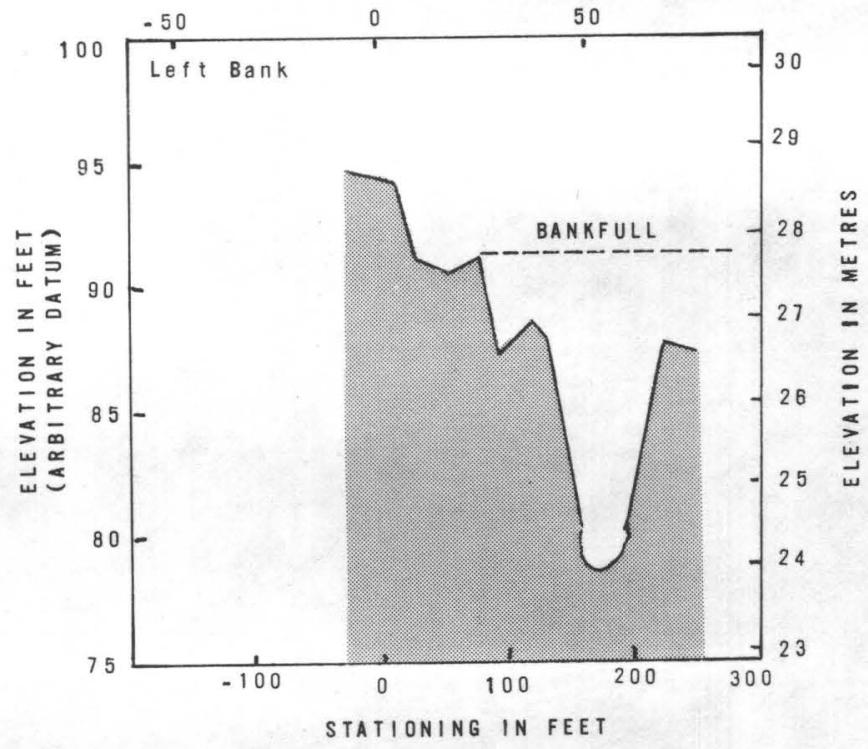

TAPS CENTERLINE CROSS SECTION

Figure 88. --

Cross sections of Sheep Creek near Valdez, Alaska, May 19, 1973.

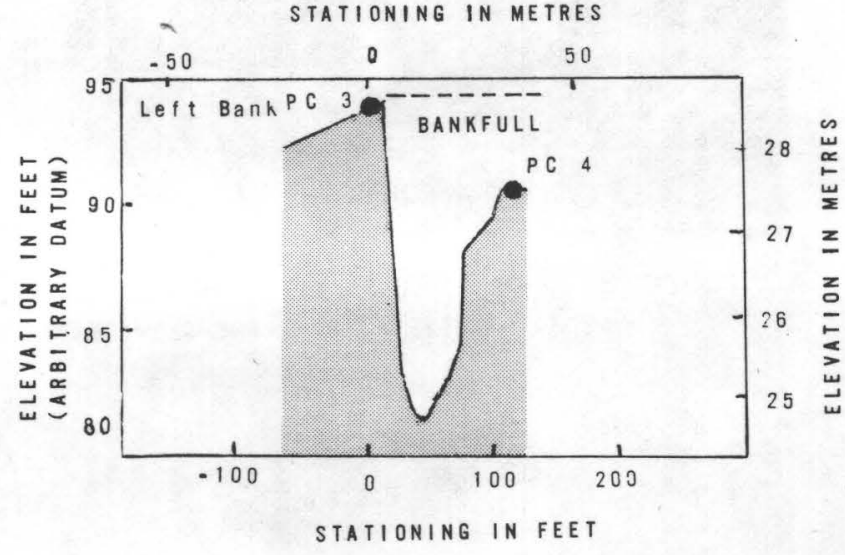


Location.--Lat $61^{\circ} 05^{\prime} 50^{\prime \prime}$, long $145^{\circ} 51^{\prime} 00^{\prime \prime}$, in SW/ sec.12, T.9 S., R.4 W., at pipeline crossing, $0.2 \mathrm{mi}(0.3 \mathrm{~km})$ upstream from Bear Creek, and $16 \mathrm{mi}(26 \mathrm{~km})$ east of Valdez.

[Valdez (A-5) 1:63,360, U.S. Geological Survey map.]

Channel conditions.--Low-altitude vertical aerial stereophotography (scale 1:2,400) was obtained September 23, 1972, (fig. 89) to document preconstruction topography of the site. Vertical aerial strip photography (scale 1:6,000) taken August 31, 1974, (fig. 90) shows the channel at moderately high flow. Comparison of the two photographs shows considerable streambed change both on Lowe River and Bear Creek. Two cross sections (fig. 91) were surveyed May 18, 1973, to define preconstruction ground profiles in the crossing reach. The TAPS centerline cross section (fig. 91, from Alyeska Pipeline Service Co. survey) was surveyed November 10, 1970. There were no construction activities in the immediate vicinity of the crossing reach for the period of erosion investigation September 23, 1972, through August 31, 1974. The construction of Sheep Creek camp in the Sheep Creek fan began in September 1974. Camp construction required a material-removal site and some diking on the main channel of the Lowe River $0.6 \mathrm{mi}(0.1 \mathrm{~km})$ above the pipeline crossing.

Floods.--A U.S. Geological Survey stream-gaging station was operated on the highway bridge at this site. Stream discharge measurements were made from the downstream side of the bridge. Figure 92 shows cross sections plotted from selected discharge measurements. The cross sections show the unstable streambed conditions at the site. The maximum discharge for the period of stream-gaging station record 1971 through September 1974 of 12,200 $\mathrm{ft}^{3} / \mathrm{s}\left(345 \mathrm{~m}^{3} / \mathrm{s}\right)$ (fig. 93) occurred August 30, 1974. The flow at flood stage inundated the gravel bars in the upstream section and TAPS centerline cross section and concentrated flow along the left bank. Floodflow in the downstream section was about bankfull. 


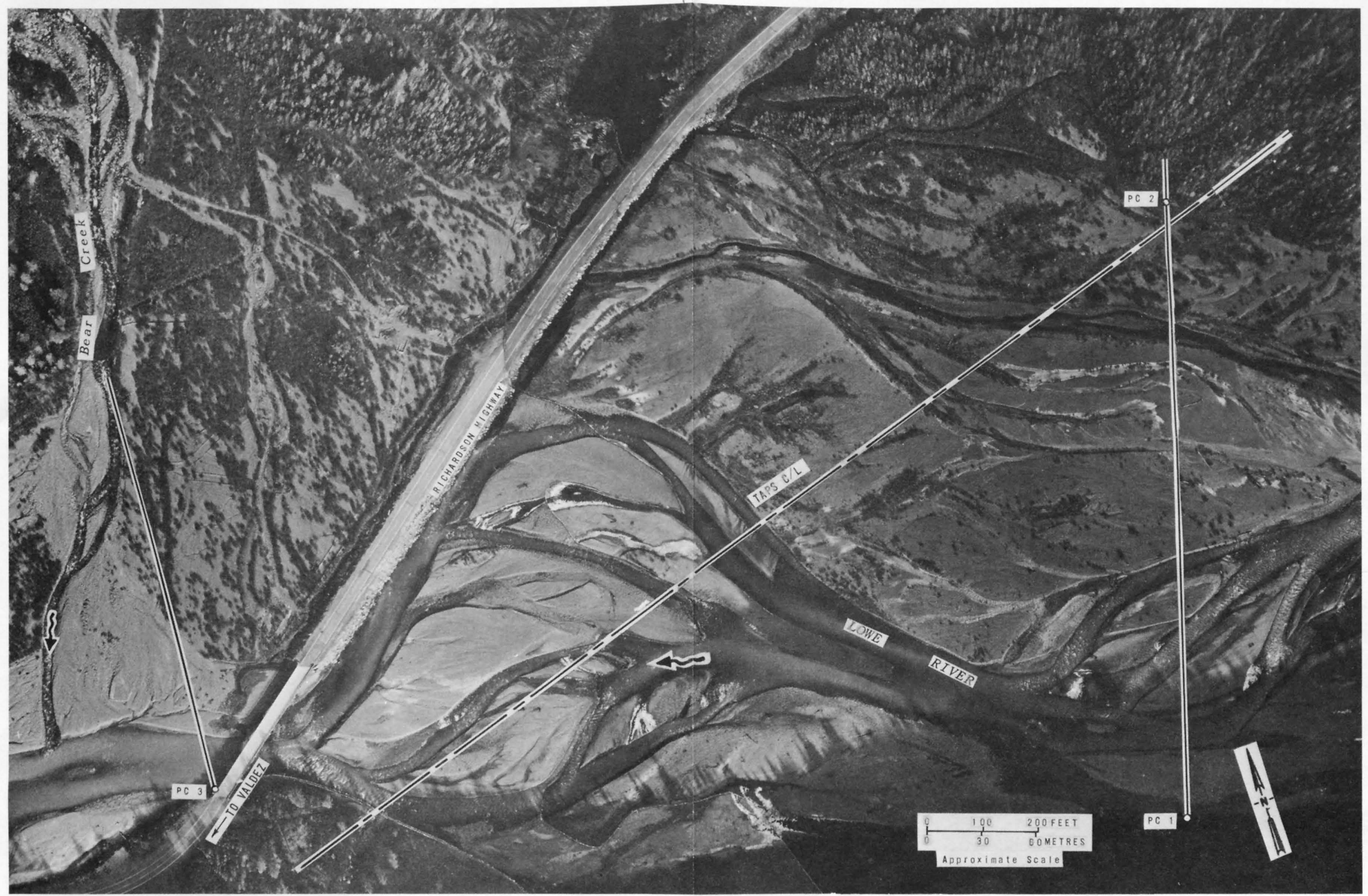

Figure 89. -- Lowe River near Valdez, September 23, 1972. NORTH PACIFIC AERIAL SURVEYS 


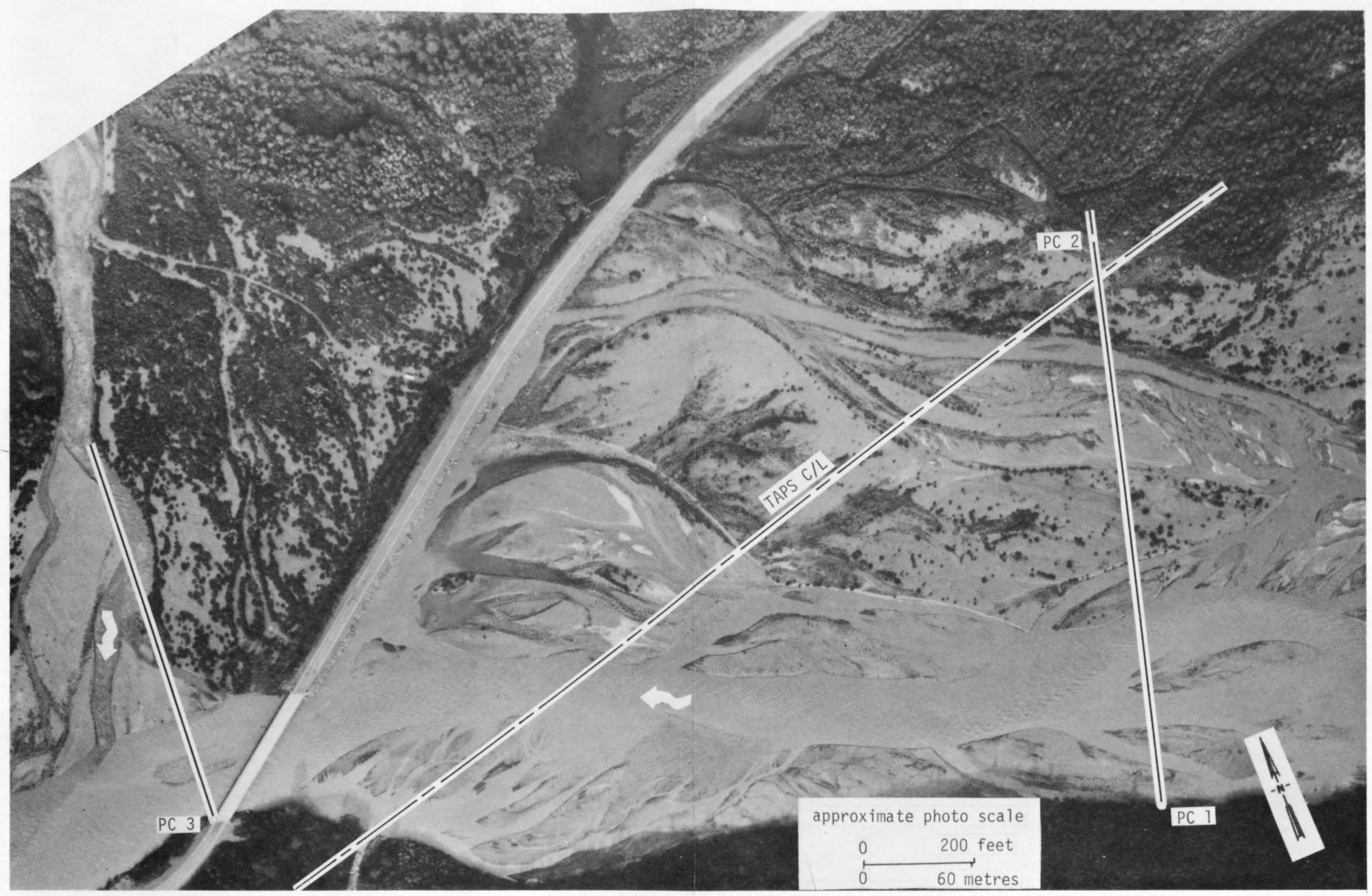

Figure 90. -- Lowe River near Valdez, August 31, 1974. alyeska PIPELINE SERVICE CO.-AIR PHOTO TECH. 

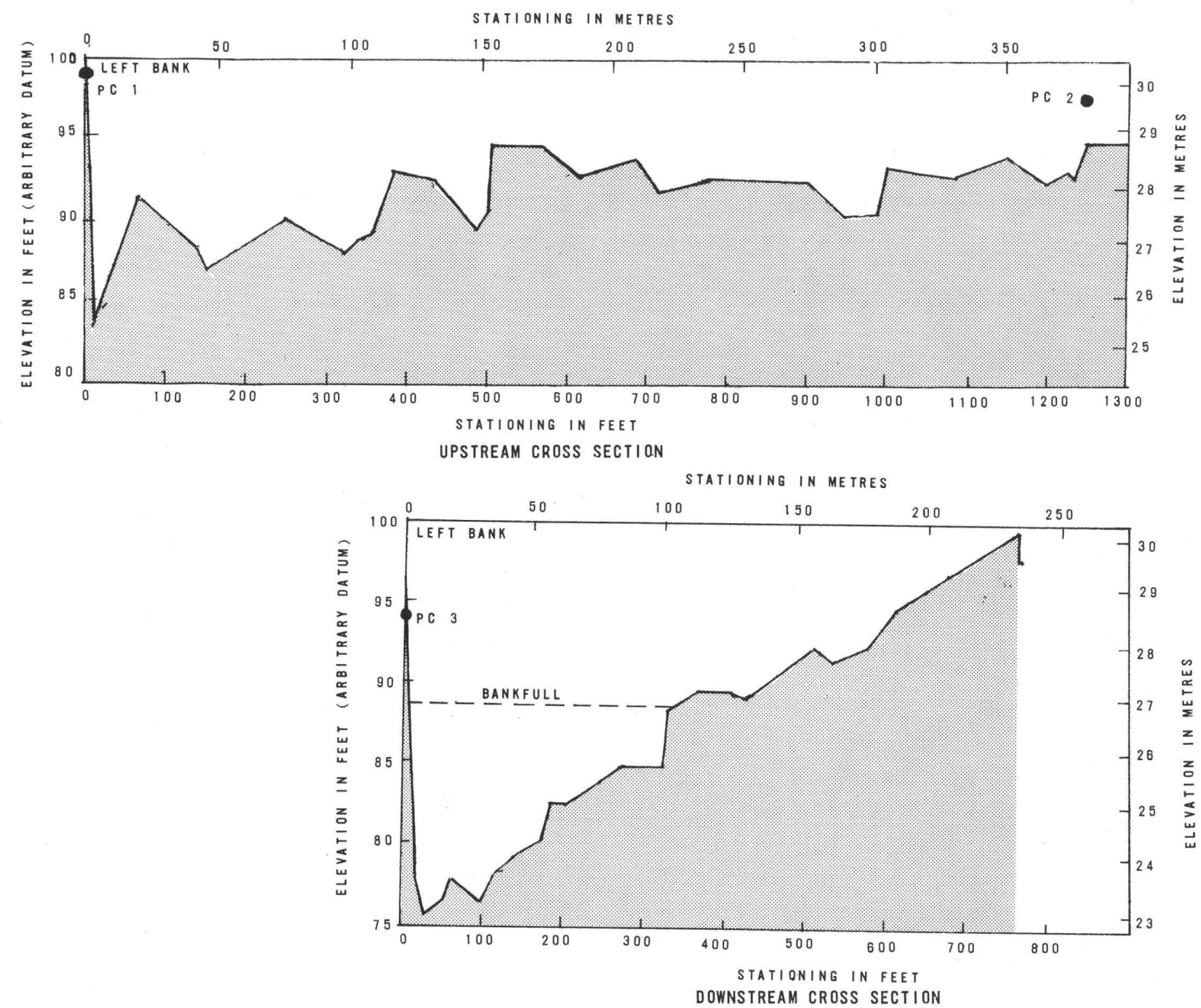

Figure 91. -- Cross sections of the Lowe River near Valdez, May 18, 1973. 

STATIONING IN METRES

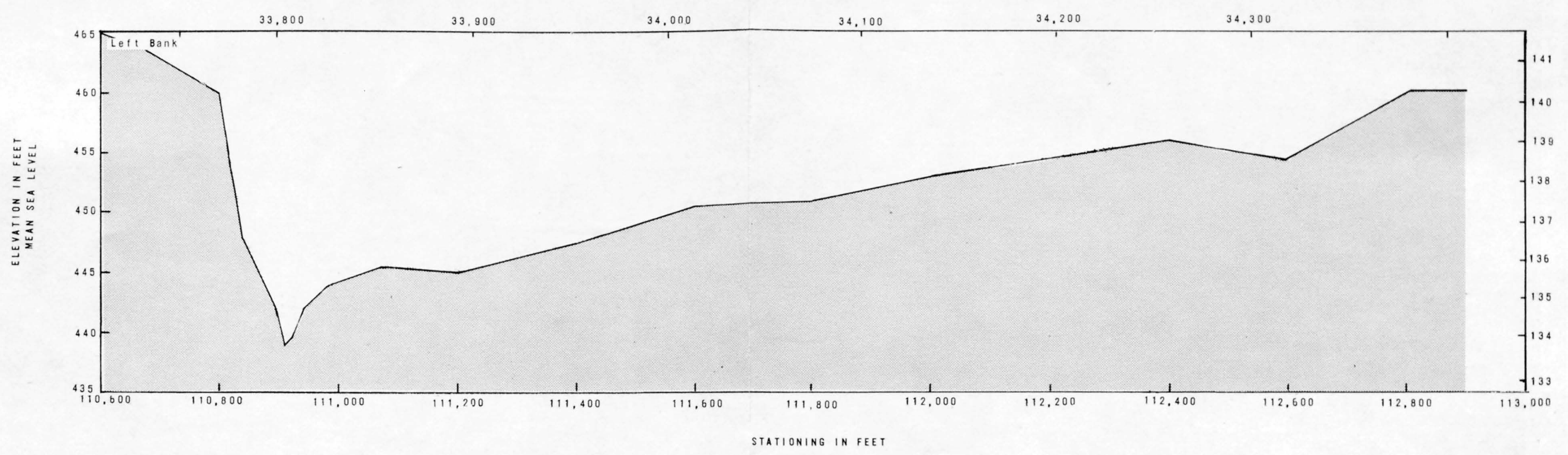

TAPS CENTERLINE CROSS SECTION

Figure 91.--Cross sections of the Lowe River near Valdez, Alaska, November 10, 1970--Continued.

From Alyeska Pipeline Service Co. Survey. 


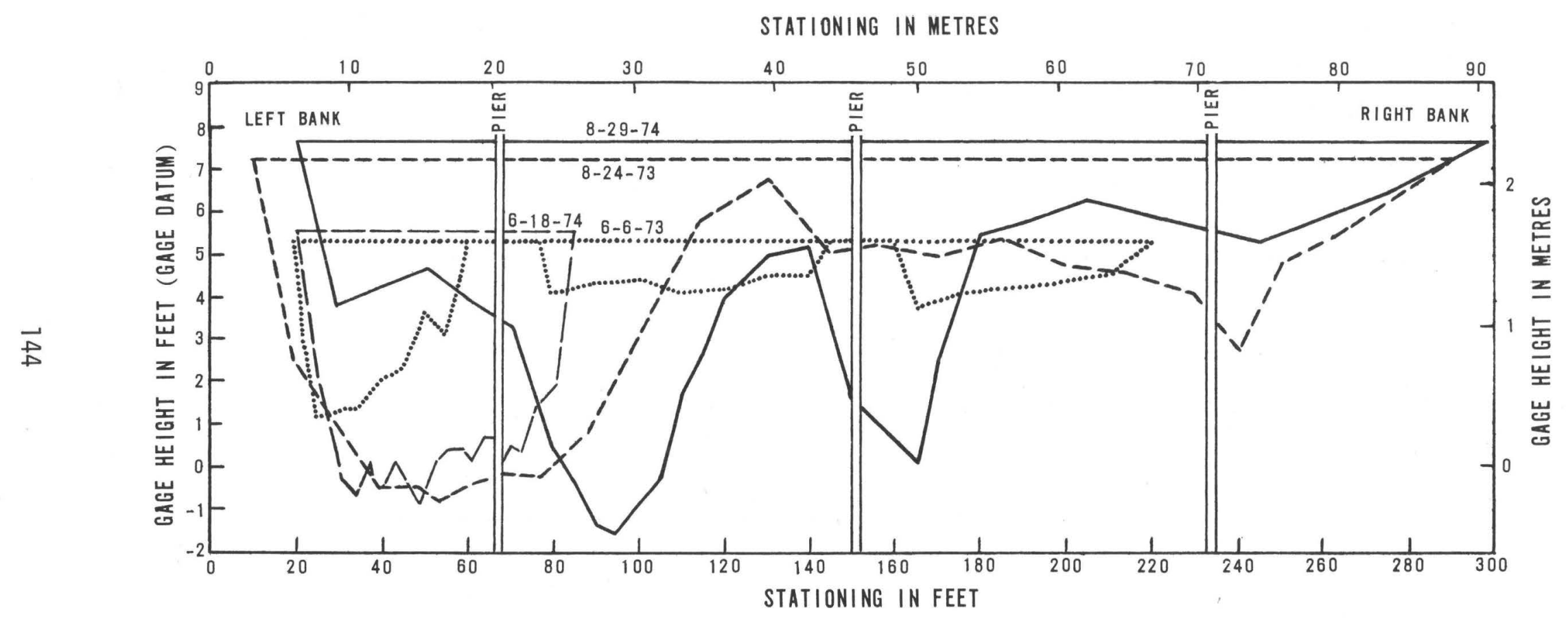

Figure 92.-- Cross section of Lowe River near Valdez, June 6,1973, August 24,1973, June 18,1974, and August 29,1974 . 


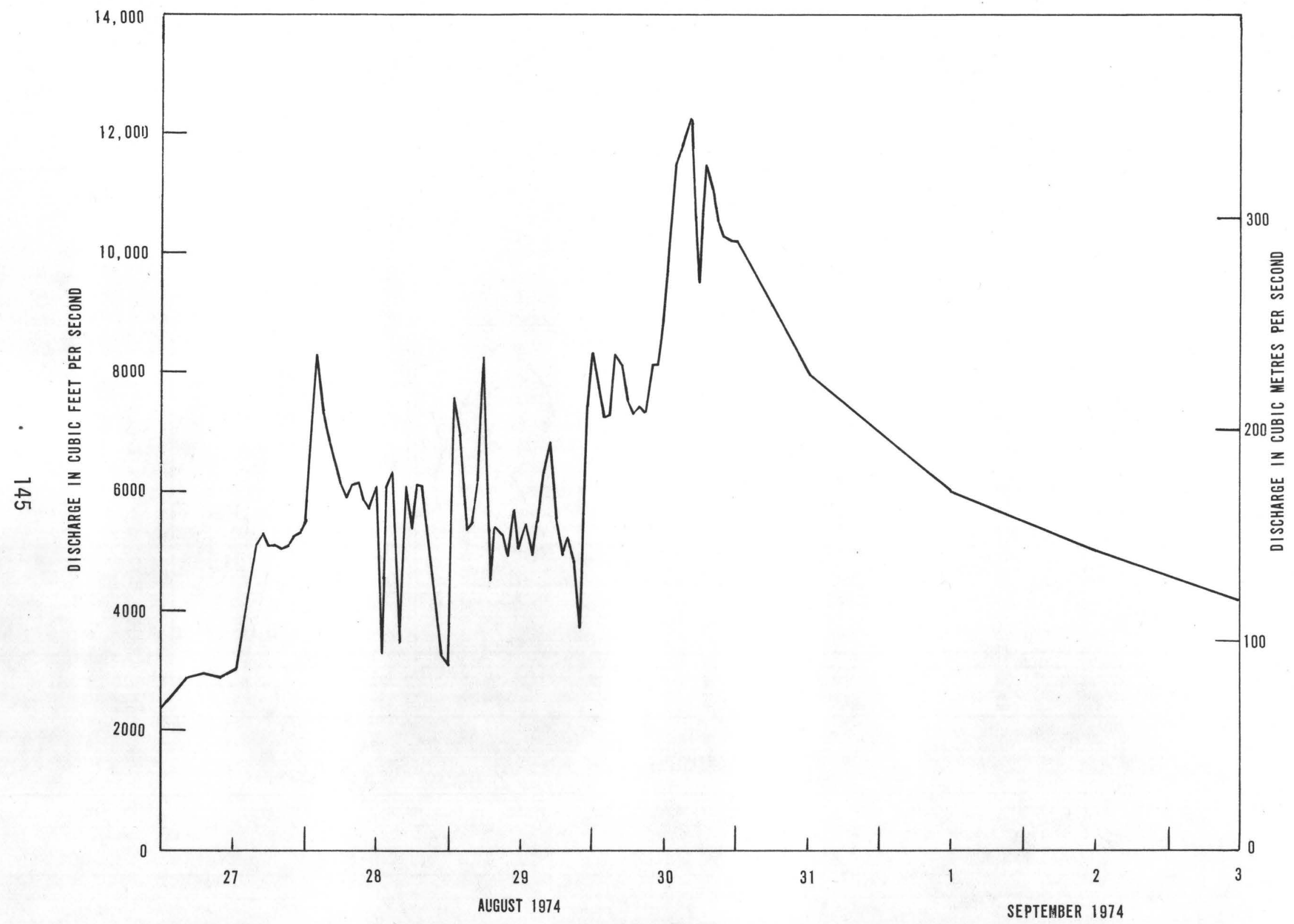

Figure 93.-- Discharge hydrograph for Lowe River near Valdez. 